\title{
Advanced materials and technologies for supercapacitors used in energy conversion and storage: a review
}

\author{
M. I. A. Abdel Maksoud 1 (1) $\cdot$ Ramy Amer Fahim ${ }^{2} \cdot$ Ahmed Esmail Shalan $^{3,4} \cdot$ M. Abd Elkodous ${ }^{5,6} \cdot$ S. O. Olojede ${ }^{7}$

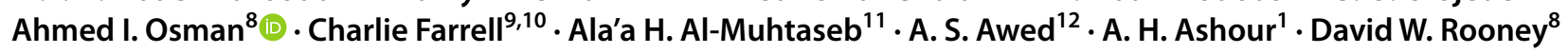

Received: 23 July 2020 / Accepted: 6 August 2020 / Published online: 28 August 2020

(c) The Author(s) 2020

\begin{abstract}
Supercapacitors are increasingly used for energy conversion and storage systems in sustainable nanotechnologies. Graphite is a conventional electrode utilized in Li-ion-based batteries, yet its specific capacitance of $372 \mathrm{~mA} \mathrm{~h} \mathrm{~g}^{-1}$ is not adequate for supercapacitor applications. Interest in supercapacitors is due to their high-energy capacity, storage for a shorter period and longer lifetime. This review compares the following materials used to fabricate supercapacitors: spinel ferrites, e.g., $\mathrm{MFe}_{2} \mathrm{O}_{4}, \mathrm{MMoO}_{4}$ and $\mathrm{MCo}_{2} \mathrm{O}_{4}$ where $\mathrm{M}$ denotes a transition metal ion; perovskite oxides; transition metals sulfides; carbon materials; and conducting polymers. The application window of perovskite can be controlled by cations in sublattice sites. Cations increase the specific capacitance because cations possess large orbital valence electrons which grow the oxygen vacancies. Electrodes made of transition metal sulfides, e.g., $\mathrm{ZnCo}_{2} \mathrm{~S}_{4}$, display a high specific capacitance of $1269 \mathrm{~F} \mathrm{~g}^{-1}$, which is four times higher than those of transition metals oxides, e.g., Zn-Co ferrite, of $296 \mathrm{~F} \mathrm{~g}^{-1}$. This is explained by the low charge-transfer resistance and the high ion diffusion rate of transition metals sulfides. Composites made of magnetic oxides or transition metal sulfides with conducting polymers or carbon materials have the highest capacitance activity and cyclic stability. This is attributed to oxygen and sulfur active sites which foster electrolyte penetration during cycling, and, in turn, create new active sites.
\end{abstract}

Keywords Supercapacitor $\cdot$ Magnetic oxides $\cdot$ Transition metals sulfides $\cdot$ Carbon materials $\cdot$ Conducting polymer materials

M. I. A. Abdel Maksoud

muhamadmqsod@gmail.com

Ahmed I. Osman

aosmanahmed01@qub.ac.uk

1 Materials Science Lab, Radiation Physics Department, National Center for Radiation Research and Technology (NCRRT), Atomic Energy Authority, Cairo, Egypt

2 Radiation Protection and Dosimetry Department, National Center for Radiation Research and Technology (NCRRT), Atomic Energy Authority, Cairo, Egypt

3 Central Metallurgical Research and Development Institute (CMRDI), P.O. Box 87, Helwan, Cairo 11421, Egypt

4 BCMaterials-Basque Center for Materials, Applications and Nanostructures, Martina Casiano, UPV/EHU Science Park, Barrio Sarriena s/n, Leioa 48940, Spain

5 Department of Electrical and Electronic Information Engineering, Toyohashi University of Technology, Toyohashi, Aichi 441-8580, Japan
6 Center for Nanotechnology (CNT), School of Engineering and Applied Sciences, Nile University, Sheikh Zayed, Giza 16453, Egypt

7 Nanotechnology Platforms, University of KwaZulu-Natal, Durban, South Africa

8 School of Chemistry and Chemical Engineering, Queen's University Belfast, David Keir Building, Stranmillis Road, Belfast, Northern Ireland BT9 5AG, UK

9 South West College, Cookstown, Co., Tyrone, Northern Ireland BT80 8DN, UK

10 School of Mechanical and Aerospace Engineering, Queen's University Belfast, Belfast, Northern Ireland BT9 5AH, UK

11 Department of Petroleum and Chemical Engineering, College of Engineering, Sultan Qaboos University, Muscat, Oman

12 Higher Institute of Engineering and Technology, Manzala, Egypt 


\section{Introduction}

Rising global population and the global energy crisis has led to concerns regarding electrical energy generation and consumption. There is therefore a need for an alternative energy storage device that has a higher capacity than the current technologies. Prior to now, the storage of electrical energy has been exclusively based on batteries and capacitors. Batteries have been the most utilized and preferred candidate, owing to high energy capacity coupled with insubstantial power evolved. However, when substantial energy is required at high power, capacitors remain the suitable device to date. Despite their benefits, both batteries and capacitors are inadequate for storing high energy and power density required for effective consumption and performance of renewable energy systems (Najib and Erdem 2019). Inventors and innovators in the field have been encountering bottlenecks with current solutions such as short lifecycles and shelf lives associated with batteries. This was only the case until revolutionary trends brought about applications of nanotechnology in the manufacturing of electrical appliances and large storage capacity devices (Burke and Zhao 2015). Nanotechnology is an advancement in the field of technology that deals with manipulation and regulation of substances on a nanoscale measurement, employing scientific skills from a diverse biomedical and industrial approach (Soares et al. 2018). Nanoparticles, a nano-size object that has three external nanoscale dimensions is the fundamental constituent of nanotechnology, while nanomaterials are materials with interior or exterior structures on the nanoscale dimension (Anu and Saravanakumar 2017; Jeevanandam et al. 2018). Nanomaterials possess unique chemical and physical characteristics that offer advantages and promotes them as an appropriate candidate for extensive utilization in fields such as electronics (Kang et al. 2015) and supercapacitors, where the storage of energy is required (Saha et al. 2018). It is now evident that the energy storage system is an important way to offer a solution to the rising demand in world energy generation and consumption (Nocera 2009).

Supercapacitors are electrochemical energy storage devices possessing both great power density and energy density with long lifecycle and high charging/discharging (Sun et al. 2018a). These properties are the reason for high-energy storage ability exhibited by supercapacitors for technological advancement (Chen and Dai 2013). SCs have been described as a capacitor that offers high storage space, larger than other capacitors with low internal resistance, which viaducts the gap between rechargeable cells and the conventional capacitors. In addition to high power capacity and longevity, low weight, large heat range of $-40^{\circ} \mathrm{C}$ to $70{ }^{\circ} \mathrm{C}$, ease to package and affordable maintenance are the main advantages supercapacitors have over other devices that stores energy
(Wang et al. 2009). The components of supercapacitors are an electrolyte, two electrodes and a separator which electrically isolate the two electrodes. These electrodes represent the most essential and fundamental constituent of supercapacitors (Pope et al. 2013; Iro et al. 2016); hence, the performance of the supercapacitors largely depends on the electrochemical properties of electrodes, the voltage range and the electrolyte. Iro et al. (2016) reported that applications of supercapacitors such as the ability to compliment the power of battery usage during emergency power supplies and in electric vehicle power systems are largely dependent on its useful attributes. Wide usefulness of supercapacitors has been described in fuel cell vehicles, low-emission hybrid vehicles, electric vehicles, forklifts, power quality upgrading and load cranes (Miller and Simon 2008; Cai et al. 2016). Fabrication of supercapacitors using printing technology has utilized diverse nanomaterials such as conductive polymers, electrolytes, transition metal carbides, transition metal dichalcogenides, nitrides and hydroxides (Sun et al. 2018a).

Magnetic metal oxide nanoparticles represent an attractive type of materials among inorganic solids because they are cheap and easy to prepare in large quantities (Masala and Seshadri 2004). Among different magnetic materials, spinel ferrites and inorganic perovskite oxides have superior performance as an electrode in supercapacitor applications. The emerging evidence has revealed that spinel ferrites of different elements are currently applicable in the design of supercapacitor energy storage devices. Spinel ferrite nanomaterials possess a high energy density, durability and good capacitance retention, high power and effective long-term stability (Elkholy et al. 2017; Liang et al. 2020). Recently, manganese zinc ferrite $\left(\mathrm{MnZnFe}_{2} \mathrm{O}_{4}\right)$ nanoneedles were successfully synthesized, with higher specific capacitance than that of $\mathrm{MnFe}_{2} \mathrm{O}_{4}$ and $\mathrm{ZnFe}_{2} \mathrm{O}_{4}$. More so, the nanoneedles fabricated were found to exhibit a high surface area, powerful long-term stability and very high columbic effectiveness, which makes it suitable for supercapacitors application (Ismail et al. 2018). Perovskite oxides are functional nanomaterials that have received great attention to potential applications, and it has been widely employed in the fabrication of anion-intercalation supercapacitors. These nanomaterials are greatly influenced by valence state of B-site element, surface area and internal resistance. More importantly, research on energy and power densities of perovskite oxides are scanty (Nan et al. 2019; Ding et al. 2017). Design of La-based perovskite with high density, wide voltage window and high energy capacity for a flexible supercapacitor application was reported in the literature (Ma et al. 2019a). Although, the transition metal oxides have relatively poor conductivity and thus poor capacitance. Therefore, an oxygen replacement with sulfur was recently performed which led to transition metal sulfides. They have been viewed as materials capable of application in the 
fabrication of supercapacitors owing to their characteristics such as good electrical conductivity, high specific capacitance, electrochemical redox sites and minimal electronegativity, which led to the synthesis of ternary nanostructures like $\mathrm{Co}_{0.33} \mathrm{Fe}_{0.67} \mathrm{~S}_{2}$ in supercapacitors application (Liu et al. 2018a). In addition, the highly flexible, lightweight asymmetric supercapacitor "graphene fibers $/ \mathrm{NiCo}_{2} \mathrm{~S}_{4}$ " was fabricated with an extremely high value of both energy density and volumetric capacity (Cai et al. 2016). This was in search for a more durable and efficient energy storage device with high volumetric capacity, high energy density and wide voltage window. The partially substituting $\mathrm{Co}$ by the transition metals (i.e., $\mathrm{Zn}, \mathrm{Mn}, \mathrm{Ni}$, and $\mathrm{Cu}$ ) in the $\mathrm{Co}_{3} \mathrm{O}_{4}$ lattice leads to produce an inverse spinel structure, in which the external cation occupies the B-sites, while cobalt occupies both the A- and B-sites (Kim et al. 2014). This presents effective channels for ion diffusion enrichment toward charge carriers (electrons or holes) that jump into the A-site and B-site for high electrical conduction (Liu et al. 2018b). $\mathrm{ZnCo}_{2} \mathrm{O}_{4}$ nanoparticles show the specific capacitance values of 202 , 668 and 843, $432 \mathrm{~F} \mathrm{~g}^{-1}$ (Bhagwan et al. 2020). The electrochemical characteristics of transition metal sulfides are much better than the electrochemical properties of transmission metal oxides. This can be explained by the presence of sulfur atoms instead of oxygen atoms. Hence, the lower electronegativity of sulfur than that of oxygen facilitates electron transfer in the metal sulfide structure easier than that in the metal oxide form. Thus, replacing oxygen with sulfur, providing more flexibility for nanomaterials synthesis and fabrication (Jiang et al. 2016). Li et al. (2019a) have found that the $\mathrm{ZnCo}_{2} \mathrm{~S}_{4}$ electrode displays an extraordinary specific capacitance $\sim 1269 \mathrm{~F} \mathrm{~g}^{-1}$, which is 4 multiplies of those for $\mathrm{Zn}-\mathrm{Co}$ ferrite electrode $\left(\sim 296 \mathrm{~F} \mathrm{~g} \mathrm{~g}^{-1}\right)$, due to the $\mathrm{ZnCo}_{2} \mathrm{~S}_{4}$ electrode having low charge-transfer resistance, and likewise, exceptional ion diffusion rate compared with achieved from the $\mathrm{ZnCo}_{2} \mathrm{O}_{4}$ electrode.

Furthermore, graphene and carbon nanotubes are carbonderived nanomaterials that have received great attention in their potential application as efficient electrode materials in the design of supercapacitors owing to their high mechanical properties with great specific surface area and most importantly competent electrical properties (Chen and Dai 2013). Further, other forms of carbon-nanomaterials like carbon derivatives, xerogel, carbon fiber, activated carbon and template carbon likewise been applied in the design of supercapacitors and they also serve as the supercapacitor's electrodes. These materials possess powerful lifecycles, durable power density, lasting cycle durability and desirable columbic reliability (Yin et al. 2014). Carbon-based nanomaterials are relatively cheap, readily accessible and very common with characteristic permeability which enables easy penetration of electrolytes into the electrodes, to boost the capacitance of the supercapacitors. Besides, its huge surface area and effective conductance of electricity make them applicable in electric supercapacitors with double layer (Yang et al. 2019a; Cheng et al. 2020a). In the same context, the extraordinary specific surface area and conductivity are demanded to secure excellent capacity achievement for the electrodes. Therefore, mineral oxide, two-dimensional carbon composites and polymer composites that possess high conductivity are normally utilized in electric devices with a high display. Especially, two-dimensional carbon composites improve capacity achievement via enhancing their surface area, porosity and electric conducting. Notwithstanding this level of concern, $\mathrm{ZnCo}_{2} \mathrm{O}_{4}$ efficiency needs more promotion by morphological and chemical modifications (Kathalingam et al. 2020). Hence, the incorporation of nitrogen-doped graphene oxide and polyaniline with the $\mathrm{ZnCo}_{2} \mathrm{O}_{4}$ affects on electrochemical performance. The prepared electrode exhibited a high capacity of about $720 \mathrm{~F} \mathrm{~g}^{-1}$ and retained $~ 96 \%$ from its original capacitance over $10 \times 10^{3}$ cycles (Kathalingam et al. 2020). Also, the fabricated $\mathrm{ZnCo}_{2} \mathrm{~S}_{4} @$ hydrothermal carbon spheres $/ \mathrm{Fe}_{2} \mathrm{O}_{3} @$ pyrolyzed polyaniline nanotubes unveiled a high capacitance about $~ 150 \mathrm{~mA} \mathrm{~h} \mathrm{~g}^{-1}$ and retained $82 \%$ from its original capacity after $6 \times 103$ cycles and confirming huge energy density $\left(\sim 85 \mathrm{~W} \mathrm{~h} \mathrm{~kg}^{-1}\right)$ at a moderate power density of $460 \mathrm{~W} \mathrm{~kg}^{-1}$ (Hekmat et al. 2020).

The conducting polymer materials are pseudo-capacitance materials with poor lifecycles when compared with carbon-based materials (Snook et al. 2010). Numerous good properties of conducting polymer materials like flexibility, conductivity, ease of synthesis, financial viability and high pseudo-capacitance conducting polymer materials such as polythiophene, polypyrrole and polyaniline have received great attention in the potential supercapacitor application. Despite these good properties, pure conducting polymer materials exhibit poor cycling stability and lower power and energy densities (Huang et al. 2017a).

This review focuses on spinel ferrites $\mathrm{MFe}_{2} \mathrm{O}_{4}, \mathrm{MMoO}_{4}$ and $\mathrm{MCo}_{2} \mathrm{O}_{4}$, where $\mathrm{M}$ denotes a transition metal ion. Additional focus areas include perovskite oxides, transition metals sulfides, carbon materials and conducting polymer materials, as materials that have been extensively and widely employed in the fabrication of supercapacitors to establish loopholes in some of these nanomaterials. This would ultimately offer guidelines on how to design better energy storage devices with a higher power, density and sufficient storage ability.

\section{Supercapacitor-based on spinel ferrites}

Spinel ferrites constitute metal oxide compounds of minute classes of transition metals that are originally obtained from magnetite $\left(\mathrm{Fe}_{3} \mathrm{O}_{4}\right)$. The spinel ferrites exhibit good magnetic and electrical characteristics, which has brought about its 
broad applications in high-density data storage, water remediation, drug delivery, sensors, spintronics, immunoassays using magnetic labeling, hyperthermia of cancer cells, optical limiting, magnetocaloric refrigeration and magnetic resonance imaging (Farid et al. 2017; Dar and Varshney 2017; Amirabadizadeh et al. 2017; Pour et al. 2017; Alcalá et al. 2017; Yan and Luo 2017; Sharma et al. 2017; Winder 2016; Samoila et al. 2017; Niu et al. 2017; Anupama et al. 2017; El Moussaoui et al. 2016; Patil et al. 2016; Ghafoor et al. 2016; Ashour et al. 2018; Amiri and Shokrollahi 2013; Ouaissa et al. 2015; Houshiar et al. 2014; Maksoud et al. 2020a, b; Abdel Maksoud et al. 2020a; Hassan et al. 2019; Patil et al. 2018; Žalnèravičius et al. 2018; Thiesen and Jordan 2008; Koneracká et al. 1999; Arruebo et al. 2007; Basuki et al. 2013; Gupta and Gupta 2005a, b; Jain et al. 2008; Liu et al. 2005; Abdel Maksoud et al. 2020b). Besides these applications, raising attention in energy storage research via dissemination is due to the fast-growing demand for electronic devices that are manufactured to be smaller, lighter and relatively cheaper. Therefore, an all-in-one device demands effective energy storage components which will fit into such design criteria with enhanced energy performance (Reddy et al. 2013; Zhu et al. 2015; Hao et al. 2015). The crystal structure of some oxides such as ionic oxides, specifically oxides of $\mathrm{Fe}$, permits visibility of complex composition of magnetic ordering. The type of such magnetic ordering is known as ferrimagnetism. The structure of these materials has two spins (up and down), and also, the net magnetic moment of all the directions is not zero (Reitz et al. 2008). For the various neighboring sublattices, the atoms' magnetic moments are opposed to each other, nevertheless, the opposing moments are unbalanced (O'handley 2000; Cullity and Graham 2011).

Spinel ferrites are distinguished via the nominal composition $\mathrm{MFe}_{2} \mathrm{O}_{4}$, where $\mathrm{M}$ denotes divalent cations possessing an ionic radius within 0.6 and $1 \AA$, such examples are magnesium, copper, nickel, manganese, zinc, cobalt, etc. Also, $\mathrm{M}$ can be substituted by any different metal ions. The ferric ions can be substituted via extra trivalent cations such as aluminum, chromium, etc. The spinel structure originates from the $\mathrm{MgAl}_{2} \mathrm{O}_{4}$ which owns a cubic structure. This crystal was first discovered by Bragg and by Nishikawa (Ashour et al. 2014).

In the spinel lattice, each cell has a cubic arrangement and comprises eight $\mathrm{MeFe}_{2} \mathrm{O}_{4}$ molecules. The large $\mathrm{O}^{2-}$ ions produce a face-centered cubic lattice. The cubic cell has two types of interstitial sites: (1) tetrahedral sites enclosed via 4 oxygen anions (A-site), (2) octahedral sites enclosed by 6 oxygen anions (B-site) (Shah et al. 2018; Yadav et al. 2018; Kefeni et al. 2020). Figure 1 shows the tetrahedral and octahedral positions in the FCC lattice (Cullity and Graham 2011; AJMAL 2009; Vijayanand 2010; Bhame 2007; Sach$\operatorname{dev} 2006)$

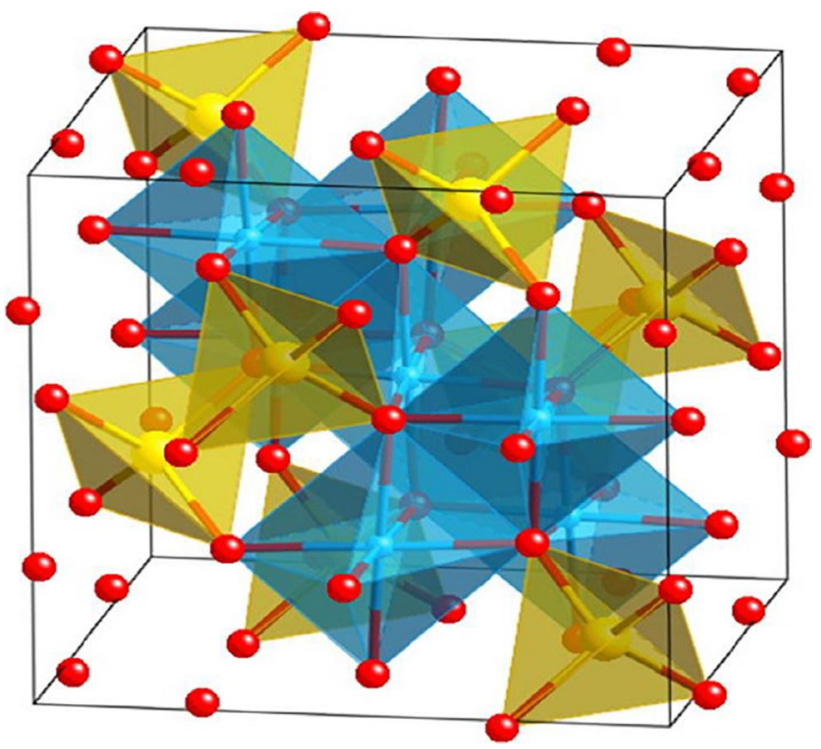

Fig. 1 Spinel ferrite structure showing oxygen (red), tetrahedral (yellow) and octahedral (blue) sites. Adapted with permission from Kefeni et al. (2020), Copyright 2020, Elsevier

On the basis of the cation distribution, ferrites can be subdivided into three classes: The possible distribution of the metal ions can be represented by the general formula (Cullity and Graham 2011):

$\left(\mathrm{M}_{\delta}^{+2} \mathrm{Fe}_{1-\delta}^{+3}\right)\left[\mathrm{M}_{1-\delta}^{+2} \mathrm{Fe}_{1+\delta}^{+3}\right] \mathrm{o}_{4}$

where $\delta$ is the degree of inversion. The ions inside the brackets () are located in tetrahedral sites, while those inside the brackets [] occupy the octahedral sites. According to this distribution, there are three categories of spinel ferrites:

1. Normal spinel $(\delta=1)$ the formula becomes $\left(\mathrm{M}^{2+}\right)\left[\mathrm{Fe}_{2}\right]$ $\mathrm{O}_{4}$ and the divalent metal ions are in tetrahedral sites. $\mathrm{ZnFe}_{2} \mathrm{O}_{4}$ and $\mathrm{CdFe}_{2} \mathrm{O}_{4}$ are examples for normal spinel ferrites.

2. Inverse spinel ferrite $(\delta=0)$ the formula becomes $\left(\mathrm{Fe}^{3+}\right)$ $\left[\mathrm{M}^{2+} \mathrm{Fe}^{3+}\right] \mathrm{O}_{4}$. In this case, the divalent metal ions completely occupy the octahedral sites while the iron is equally divided between the tetrahedral and octahedral sites. $\mathrm{NiFe}_{2} \mathrm{O}_{4}$ and $\mathrm{CoFe}_{2} \mathrm{O}_{4}$ are examples of inverse spinel ferrites.

3. Intermediate ferrite $(0<\delta<1)$ in which the $\mathrm{M}$ and $\mathrm{Fe}^{3+}$ ions are distributed uniformly over the tetrahedral and octahedral sites. $\mathrm{MnFe}_{2} \mathrm{O}_{4}$ is an example of the intermediate ferrites (Cullity and Graham 2011).

For anode materials, three varieties of available chargestorage mechanisms are considered: alloying-de-alloying, intercalation-deintercalation and conversion reactions (Park et al. 2010; Zhang 2011; Kumar et al. 2004). The 
conversion-reaction mechanism applies to spinel ferrites as one of the oxides of transition elements. In spinel ferrites and through the initial discharging process, the crystal structure is destructed into different mineral particles, following with the production of the $\mathrm{Li}_{2} \mathrm{O}$ form. As mineral particles promote the electrochemical action using the production/destruction of $\mathrm{Li}_{2} \mathrm{O}$ that supplies the route for the conversion reaction mechanism (Jiang et al. 2013; Yuvaraj et al. 2016). To obtain an extraordinary power and excellent energy density Li-ion batteries, suitable electrode materials with remarkable specific capacities, cell voltages and Li-dispersion coefficients are necessary. After the effort of Poizot et al. (2000), transition metal-oxide nanoparticles have been examined as a possible electrode for $\mathrm{Li}$-ion batteries. They are extraordinary electrochemical characteristics reaching $700 \mathrm{~mA} \mathrm{~h} \mathrm{~g}^{-1}$ with no loss of their initial capacitance over 100 lifecycles at special rates of charging. This superior electrochemical reactivity of spinel ferrites confirmed that they attend to the developed satisfaction of such batteries.

\section{Spinel $\mathrm{MFe}_{2} \mathrm{O}_{4}$ where $\mathrm{M}$ is $\mathrm{Co}, \mathrm{Zn}$ and $\mathrm{Mn}$}

In the past few years, attention has shifted toward the application of spinel ferrite and their derivative composites (Shin et al. 2018; Reddy and Yun 2016). The spinel ferrite which has nominal composition $\mathrm{MFe}_{2} \mathrm{O}_{4}$, where $\mathrm{M}$ is magnesium, zinc, copper, manganese, nickel and cobalt, present notable discharging of capacitance up to $1000 \mathrm{~mA} \mathrm{~h} \mathrm{~g}{ }^{-1}$, which is about three orders of magnitude higher than commercial anodes made from graphite (Yuvaraj et al. 2016; Yin et al. 2013).

\section{Cobalt ferrite $\mathrm{CoFe}_{2} \mathrm{O}_{4}$ nanoparticles}

The nanoparticles of cobalt ferrite $\mathrm{CoFe}_{2} \mathrm{O}_{4}$ are a common ferromagnetic substance. The $\mathrm{CoFe}_{2} \mathrm{O}_{4}$ has an inverse spinel structure where $\mathrm{Co}^{2+}$ ion species are located at the B-site and the $\mathrm{Fe}^{3+}$ ion species are found at both the $\mathrm{A}$ and $\mathrm{B}$ sites as in the formula $\left(\mathrm{Fe}^{3+}\right)\left[\mathrm{Co}^{2+} \mathrm{Fe}^{3+}\right] \mathrm{O}_{4}$. Interestingly, the ferrite materials are an interlacing structure of metal ions with positive charges and divalent oxygen ions with their negative charge. $\mathrm{CoFe}_{2} \mathrm{O}_{4}$ is a likely suitable for sensing devices as well as active and passive microwave devices due to its remanence, coercivity and high resistance (Sharifi et al. 2012; Yin et al. 2006). Also, $\mathrm{CoFe}_{2} \mathrm{O}_{4}$ is cubic in structure belonging to the $\mathrm{Fd} 3 \mathrm{~m}$ space group. Further, it is an insulator $\left(\rho \approx 10^{5} \Omega \mathrm{m}\right)$ with saturation magnetization $=90 \mathrm{~A} \mathrm{~m}^{2} \mathrm{~kg}^{-1}$ and magnetic moment $\left(\mu=3.7 \mu_{\mathrm{B}}\right)$. In this circumstance, millimetre-sized single crystals of $\mathrm{CoFe}_{2} \mathrm{O}_{4}$ show almost an insignificant coercive field. Moreover, at $300 \mathrm{~K}$, the crystallites $\mathrm{CoFe}_{2} \mathrm{O}_{4}$ samples sized 120 and $40 \mathrm{~nm}$ exhibit coercive fields of about 453 and 4650 Oe, respectively (Amiri and Shokrollahi 2013; Ouaissa et al. 2015; Houshiar et al. 2014).
Also, $\mathrm{CoFe}_{2} \mathrm{O}_{4}$ stores Li-ions via a conversion reaction, and it theoretically possesses a unique specific capacitance $\left(>900 \mathrm{~mA} \mathrm{~h} \mathrm{~g}^{-1}\right.$ ). However, it has critical disadvantages like high volume change that affects the trituration and accumulation of the active material and high resistivity that leads to reduced cycling stability and a lowering rate capability of the $\mathrm{CoFe}_{2} \mathrm{O}_{4}$ (Lavela et al. 2009; Kumar et al. 2014). Lately, Hennous et al. (2019) have studied the ${ }^{57} \mathrm{Fe}$ Mossbauer spectra of $\mathrm{CoFe}_{2} \mathrm{O}_{4}$ as a function of temperature (Fig. 2). Every spectrum produces a splitting owns magnetic nature (almost 6-line) including a broadening line attributed to the aligned $\mathrm{Fe}$ ions via a magnetic field locating various dissimilar sites. The reverse sextets arise due to the diverse number of cobalt and iron neighbors in tetrahedral and octahedral sites. At low temperatures, the tetrahedral site has a magnetically hyperfine field (50 Tesla) and declines regularly with rising its temperature (to 40 Tesla in $227 \mathrm{C}$. While, the octahedral site has a magnetic hyperfine field bigger than its value in the other site (tetrahedral site), which declined also with arising temperature. The nanoparticles of $\mathrm{CoFe}_{2} \mathrm{O}_{4}$ can enhance the capacitance of the composite electrode and have an immeasurable electrochemical activity, which leads to the improvement in energy and power densities of a supercapacitor. Recently, Elseman et al. (2020) have established a facile onestep pathway to synthesize $\mathrm{CoFe}_{2} \mathrm{O}_{4} /$ carbon spheres nanocomposite as a novel electrode. The glucose (as a source for carbon spheres) was directly combined with $\mathrm{CoFe}_{2} \mathrm{O}_{4}$ via the solvothermal approach at specific conditions. The electrode has significantly increased the electrochemical capacitance of $600 \mathrm{~F} \mathrm{~g}^{-1}$, with loss of $5.9 \%$ of its initial capacitance over $5 \times 10^{3}$ exhibiting an energy density of $27.08 \mathrm{~W} \mathrm{~h} \mathrm{~kg}^{-1}$ and a power density $750 \mathrm{~W} \mathrm{~kg}^{-1}$. This can be attributed to its structure which is hierarchical shaped allowing great electrical conductance. These results showed that the prepared composite electrode has much high specific capacity with maximum retention ability. Finally, the results affirmed that the electrode is very attractive applicants for supercapacitor materials. Also, Reddy et al. (2018a) have used $\mathrm{ZnO}$ to increase the electrochemical properties of $\mathrm{CoFe}_{2} \mathrm{O}_{4}$. The electrochemical analyses showed that the $\mathrm{ZnO} @ \mathrm{CoFe}_{2} \mathrm{O}_{4}$ nanocomposite electrode in a $3 \mathrm{M} \mathrm{KOH}$ aqueous solution performed a large specific capacitance $\left(4050 \mathrm{~F} \mathrm{~g}^{-1}\right)$, with an excellent energy density about $77 \mathrm{~W} \mathrm{~h} \mathrm{~kg}^{-1}$. This electrode presented excellent cycling stability and retained about $91 \%$ of its specific capacitance after 1000 cycles. Besides, the electrode exhibited a specific capacitance $\left(\sim 3500 \mathrm{~F} \mathrm{~g} \mathrm{~g}^{-1}\right)$ and cycling stability ( 50\%) lower than the $\mathrm{ZnO} @ \mathrm{CFO}$ nanocomposite electrode. These outcomes of the nanocomposite were confirmed as electrodes for subsequent generation supercapacitor. 
Fig. $2{ }^{57} \mathrm{Fe}$ Mossbauer spectra as a function of temperature for $\mathrm{CoFe}_{2} \mathrm{O}_{4}$. The figure illustrates splitting and magnetic nature of $\mathrm{CoFe}_{2} \mathrm{O}_{4}$ where each broadening line assigned to iron ions via a magnetic field settling multiple disparate sites. Adapted with permission from Hennous et al. (2019), Copyright 2019, Royal Society of chemistry

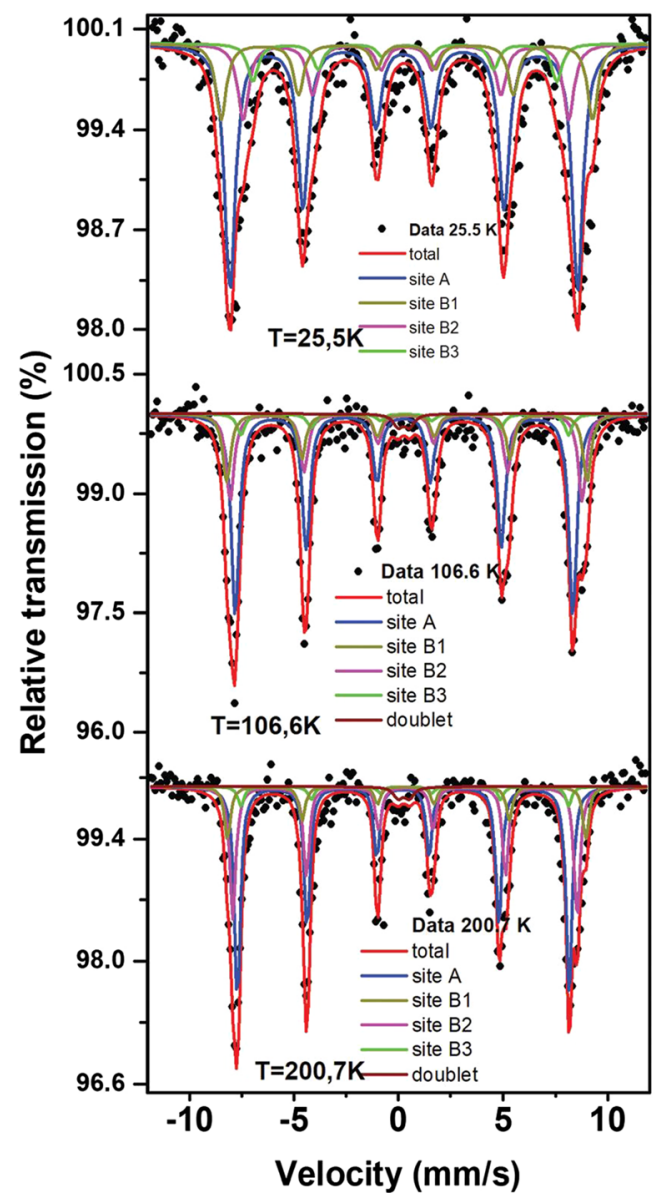

\section{Zinc ferrite $\mathrm{ZnFe}_{2} \mathrm{O}_{4}$}

$\mathrm{Zn}$ ferrite is the common material for electrochemical applications due to its eco-friendly nature, sufficient resources, cost-effectiveness, strong redox process and extraordinary theoretical capacity of $2600 \mathrm{~F} \mathrm{~g}^{-1}$ (Vadiyar et al. 2015, 2016a; Raut and Sankapal 2016; Zhang et al. 2018a). However, its lower conductivity, volume fluctuations during charge and discharge rhythm and low cycling stability cycles make it unsuitable for efficient supercapacitors. To defeat those disadvantages, the conducting polymers or conducting materials were added to the $\mathrm{Zn}$ ferrite to enhance the electronic conductivity and to improve the cycling stability (Yang et al. 2018; Qiao et al. 2018). Israr et al. (2020) have synthesized a nanocomposite series of $\mathrm{Zn}$ ferrite/nanoplatelets of graphene. The cyclic voltammetry curves for the as-synthesized electrode are displayed in Fig. 3. The figure shows that the curve shape is kept fixed for electrode even at higher scan rates, meaning its higher rate ability. It is worth to mention that the conducting network of graphene created within the formation of the nanocomposite is the main reason for this higher specific capacity and great rate ability. The high conductance of nanoplatelets of graphene within the nanocomposite structure makes efficient transport of charge as well as develops the electrode's capability rate. The synthesized nanocomposites can be applied as electrochemical capacitors with an excellent capacitance of $314 \mathrm{~F} \mathrm{~g}^{-1}$, great performance rate and lost about $22.6 \%$ of its initial capacitance.

In the same context, Yao et al. (2017) have successfully synthesized carbon-coated $\mathrm{Zn}$ ferrite/graphene composite by a general multistep strategy. During the anodic process, one broad peak rises at $\sim 1.50-2.10 \mathrm{~V}$, representing the oxidation of the base zinc ions $\left(\mathrm{Zn}^{0}\right.$ to $\left.\mathrm{Zn}^{2+}\right)$ and iron ions, i.e., $\mathrm{Fe}^{0}$ to $\mathrm{Fe}^{3+}$. The electrochemical analyses confirm that electrode offers a discharge capacity (initial) with a value of $1235 \mathrm{~mA} \mathrm{~h} \mathrm{~g}^{-1}$ and loss about $465 \mathrm{~mA} \mathrm{~h} \mathrm{~g}^{-1}$ over 150 cycles with a high value of capacity and good cycling performance. The microstructural stability and the very low accumulation of hierarchical spheres of electrode are the most common reasons for allowing appropriate transportation of the ion/electrons leading to this enhanced electrochemical achievement. The electrochemical results are influenced by carbon layer novel architectures ( 3-6 nm) and graphene nanosheets with ultrathin thickness. The studied electrode can be applied in Li-ion batteries as a high-performance alternative anode. 

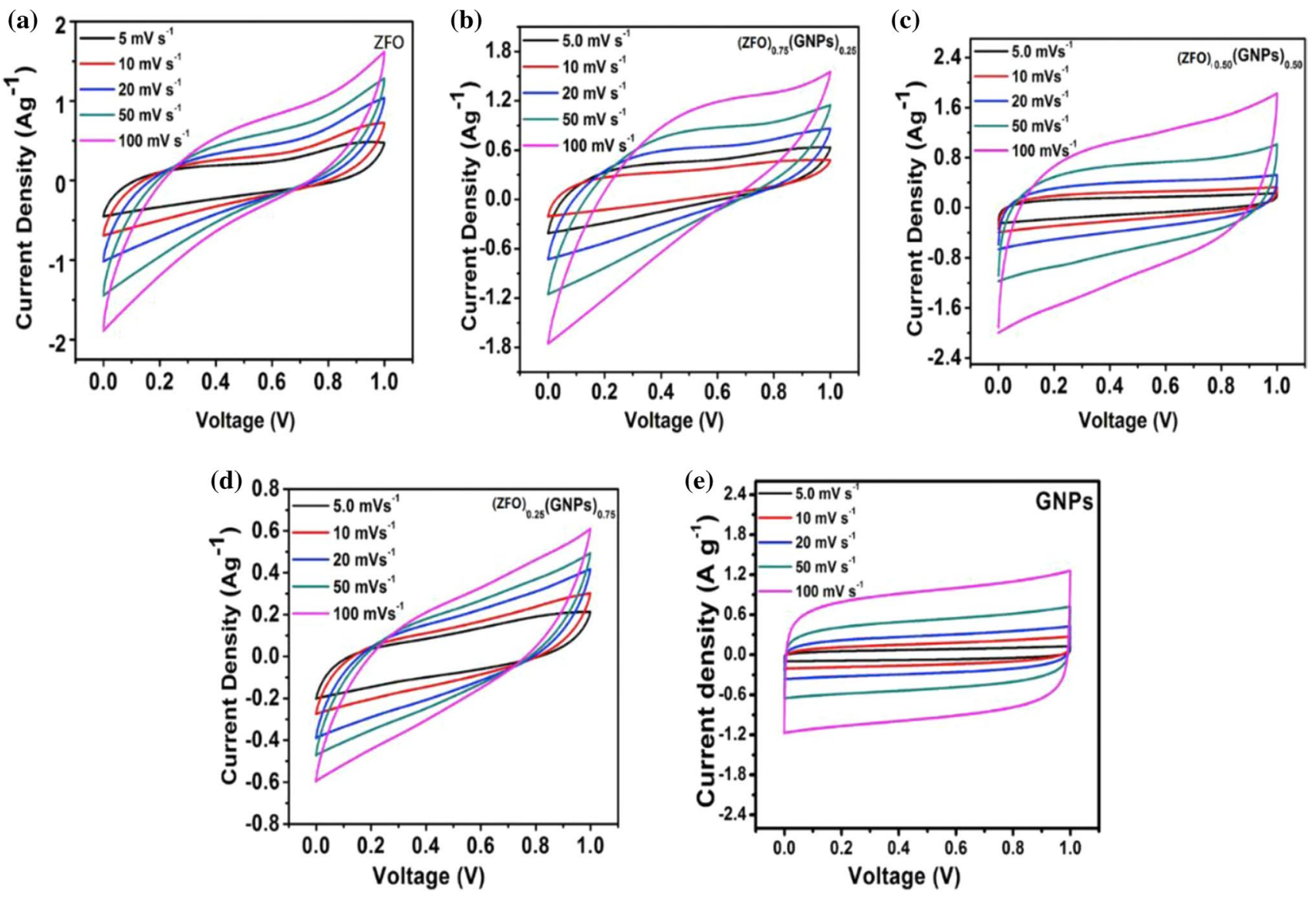

Fig. $3(\mathrm{ZFO})_{1-\mathrm{x}}(\mathrm{GNPs})_{\mathrm{x}}$ electrodes $\mathrm{CV}$ curves, where $\mathrm{ZFO}$ is refer to $\mathrm{Zn}$ ferrite and GNPs refer to nanoplatelets of graphene. Adapted with permission from Israr et al. (2020), Copyright 2020, Elsevier

\section{Manganese ferrite $\mathrm{MnFe}_{2} \mathrm{O}_{4}$}

Spinel $\mathrm{MnFe}_{2} \mathrm{O}_{4}$ is characterized by rapid valence-state response-ability, high electrochemical activity along with it is a cheap, readily available and eco-friendly material. Therefore, spinel Mn ferrite NPs has been lately examined as proper electrodes for batteries based on lithium and sodium ions, batteries of metal-air and SCs (Xiao et al. 2013; Sankar and Selvan 2014, 2015; Lin and $\mathrm{Wu} 2011$ ). But, the Mn ferrite has reduced both rate capability and cycling stability due to the inferior electrical conductivity and the serious effect of ion insertion/deinsertion performance during the charging/discharging process (Cheng et al. 2011; Guan et al. 2015; Wang et al. 2014a). Because of the integrated advantages of the quantum dot, it can be assumed that when the size of spinel Mn ferrite decreased into the quantum scale, the available surface area and the electrochemically active sites will greatly be developed in addition to rapid surfacecontrolled pseudo-capacitance behavior with reduction in the ion carrying route (Su et al. 2018). Besides, the electrode has an excellent performance rate owing to the integration between the great capacitance and extraordinary cycling stability. Su et al. (2018) have demonstrated the successful preparation of Mn ferrite@Nitrogen-doped graphene via the solvothermal method. The prepared electrode displays an extraordinary capacity of about $\sim 517 \mathrm{~F} \mathrm{~g}^{-2}$. Furthermore, carbon encapsulation is promising for the development for rate and cycling achievement, providing a satisfying capacitance $\left(\sim 150 \mathrm{~F} \mathrm{~g}^{-1}\right)$ as well as an excellent lifecycle up to $65 \times 10^{3}$ cycles. These conclusions make the prepared materials are proper electrodes for energy storage applications.

The influence of electrolyte types on the electrochemical performance of Mn ferrite was evaluated. Vignesh et al. (2018) have documented a facile synthesis of Mn ferrite by co-precipitation technique. The electrochemical analysis of $\mathrm{Mn}$ ferrite was examined with various types of electrolytes, such as potassium hydroxide, lithium phosphate and lithium nitrate (Fig. 4). The highest capacity of $173 \mathrm{~F} \mathrm{~g}^{-1}$ via using potassium hydroxide, $31 \mathrm{~F} \mathrm{~g}^{-1}$ via using lithium nitrate and $430 \mathrm{~F} \mathrm{~g}^{-1}$ via using lithium phosphate were achieved.

Between these electrolytes, the potassium hydroxide electrolyte showed loss about $40 \%$ from its original capacitance with highest performance rate due to high accessibility of surface, synergistic activities and improved 



Fig. 4 Cyclic voltammetry profile and specific capacitance as a function of the current density of $\mathrm{MnFe}_{2} \mathrm{O}_{4}$ electrode materials in aqueous $\mathrm{KOH}(\mathbf{a}-\mathbf{c})$, lithium nitrate $(\mathbf{d}-\mathbf{f})$, lithium phosphate $(\mathbf{g}-\mathbf{i})$ as electrolytes, respectively. It is illustrated that the results achieved a high capacity of $173 \mathrm{~F} \mathrm{~g}^{-1}$ via using potassium hydroxide, $31 \mathrm{~F} \mathrm{~g}^{-1}$ via using lithium nitrate and $430 \mathrm{~F} \mathrm{~g} \mathrm{~g}^{-1}$ via using lithium phosphate. Adapted with permission from Vignesh et al. (2018), Copyright 2018, Elsevier electronic conductivity of $\mathrm{Mn}$-ferrite. Besides, the synthesis of symmetric cells via Mn-ferrite as an electrode material with potassium hydroxide as an electrolyte presented power density, specific capacitance and energy density of $1207 \mathrm{~W} \mathrm{~kg}^{-1}, 245 \mathrm{~F} \mathrm{~g}^{-1}$ and $12.6 \mathrm{~W} \mathrm{~h} \mathrm{~kg}^{-1}$, respectively. Moreover, the Mn-ferrite keeps more than $105 \%$ of its original capacity after $10 \times 10^{3}$ cycles.

\section{Spinel metal molybdates}

The binary metal molybdates $\left(\mathrm{NiMoO}_{4}, \mathrm{CoMoO}_{4}, \mathrm{FeMoO}_{4}\right.$, etc.) have gained significant interest in the energy-related research area (compared to metal oxides, hydroxides and sulfides). This is due to their low cost, environmental friendliness, abundant resources, suitable electrical, electrochemical and mechanical properties for high capacity supercapacitors (Zhang et al. 2019a; Huang et al. 2016a). Lately, researchers have focused on the improvement in metal molybdates as electrode materials for supercapacitor applications.

\section{Nickel molybdate $\mathrm{NiMoO}_{4}$}

The nickel molybdate $\mathrm{NiMoO}_{4}$ has gained significant attention in recent years as a proper electrode material for supercapacitor, due to its inexpensive cost, unlimited sources, 
great redox activity, well-defined redox performance and eco-friendly compatibility (Guo et al. 2014; Yin et al. 2015a). The nickel molybdate has many crystals' shapes, and this depends upon the synthesizing technique and temperature of the annealing process as illustrated in Fig. 5 (Kumar et al. 2020; Liu et al. 2013a; Chen et al. 2015; Hussain et al. 2020).

The specific capacitance and better cycling stability of nickel molybdate are dependent on the crystals' shapes. Ajay et al. (2015) observed that the two-dimensional nickel molybdate like-nanoflakes synthesized via rapid microwave-assisted achieved $1739 \mathrm{~F} \mathrm{~g}^{-1}$ of specific capacitance at $1 \mathrm{mV} \mathrm{s}^{-1}$ of scan rates. While, Huang et al. (2015a) found that three-dimensional form interconnected nickel molybdate like-nanoplate arrays show a specific capacitance as high as $2138 \mathrm{~F} \mathrm{~g}^{-1}$ at a current density of $2 \mathrm{~mA} \mathrm{~cm}^{-2}$, and an outstanding cyclability where lost $13 \%$ of its original capacity over $3 \times 10^{3}$ cycles. Also, Cai et al. (2013), have synthesized nickel molybdate nanospheres and nanorods via simple hydrothermal techniques. The nickel molybdate nanospheres displayed a higher value of specific capacitance and good both stability of its lifecycle and rate capability than nickel molybdate nanorods. This behavior may be due to their massive surface area and good electrical conductivity. Nickel molybdate nanospheres displayed $\sim 974 \mathrm{~F} \mathrm{~g}^{-1}$ of specific capacitances while it was $\sim 945 \mathrm{~F} \mathrm{~g}^{-1}$ for nanospheres. In another study, Cai et al. (2014a) observed that the mesoporous nickel molybdate like-nanosheets displayed a higher specific capacitance and cycling stability than nickel molybdate like-nanowires.

Notwithstanding these benefits, nickel molybdate as metal oxides materials undergoes lower cyclic stability attributed
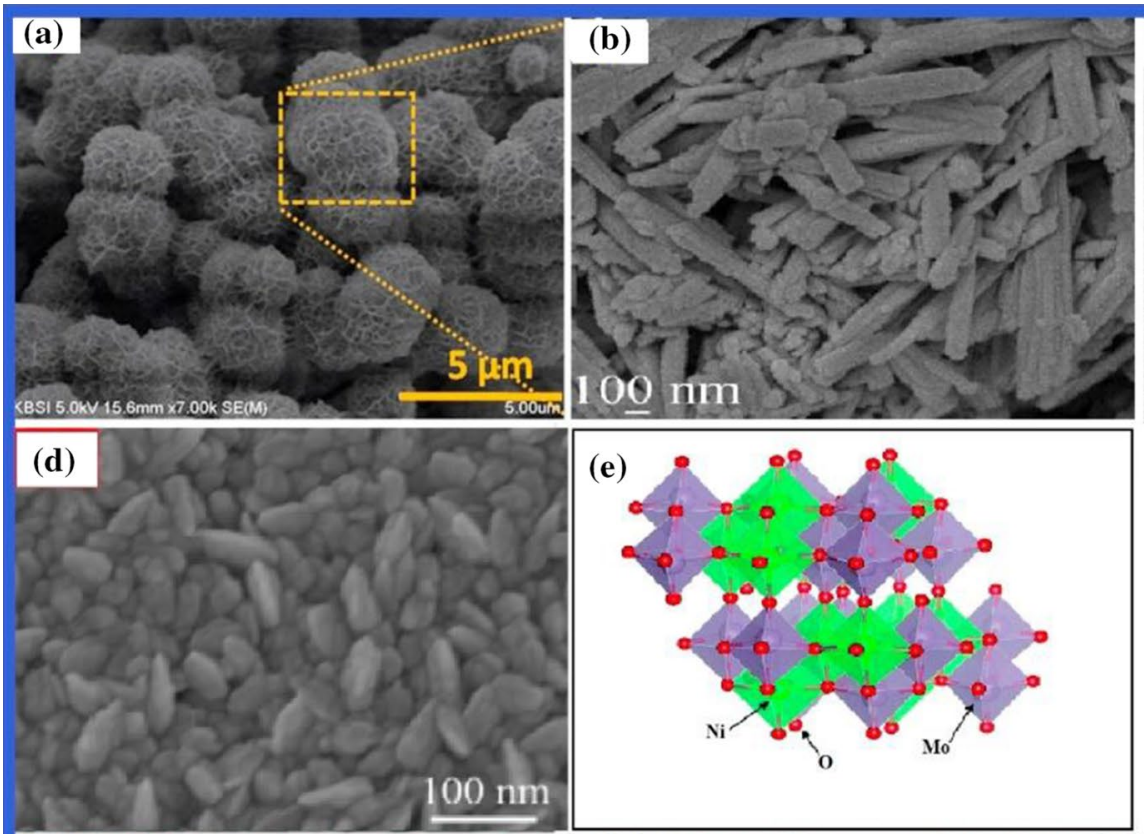

\section{(e)}
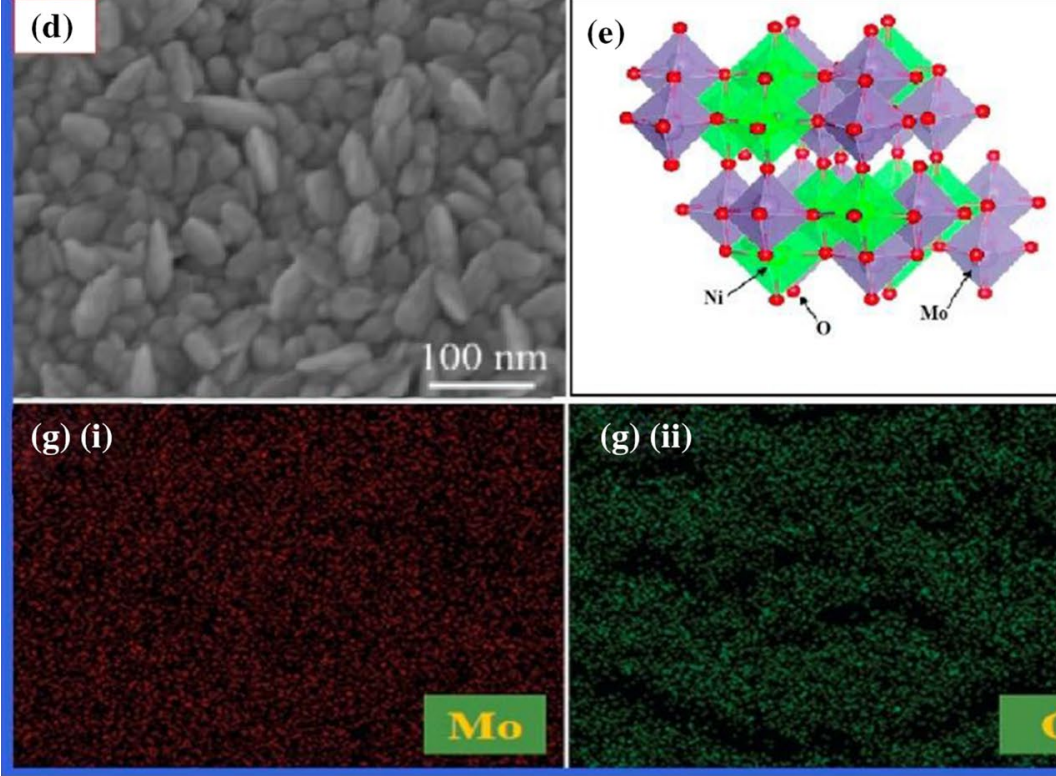

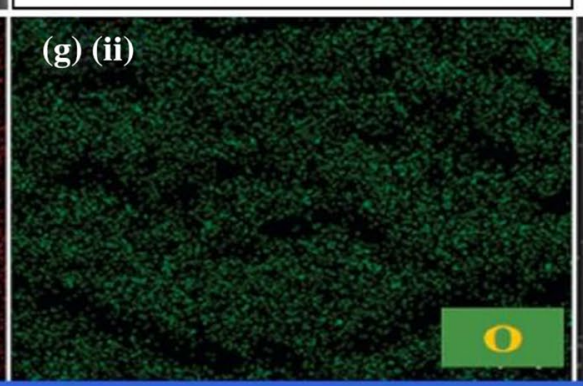

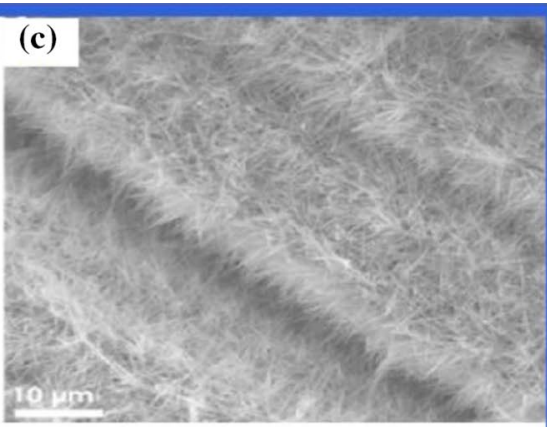
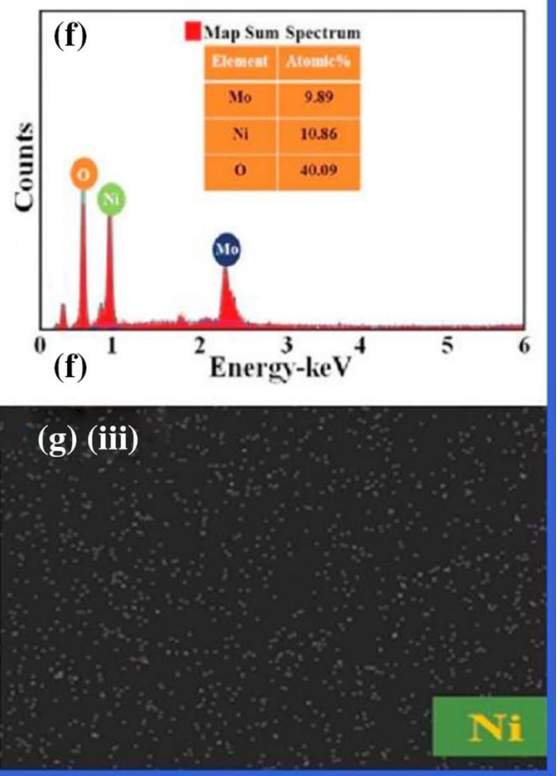

Fig. 5 Nickel molybdate has many crystals' shapes, and this depends upon the synthesizing technique and temperature of the annealing process. a-d SEM images of a nanoflower, adapted with permission from Kumar et al. (2020). Copyright 2020, Royal Society of Chemistry, b nanorods, adapted with permission from Liu et al. (2013a), Copyright 2013, Royal Society of chemistry; c nanowire, adapted with permission from Chen et al. (2015), Copyright 2015, Elsevier; d nanogravel, adapted with permission from Hussain et al. (2020), Copyright 2020, Elsevier; e the crystal structure, adapted with permission from Huang et al. (2018a), Copyright 2018, Royal Society of Chemistry; f, $\mathbf{g}$ EDX spectra and elemental mapping images, adapted along with permission from Kumar et al. (2020) Copyright in 2020, Royal Society of Chemistry, for nickel molybdate ferrite 
to structural degradation induced via the hard-redox reactions. Furthermore, the breakdown of the nanostructure produced via the high volume change, particle agglomeration and variable solid electrolyte interface creates an extreme reduction in capacity (Budhiraju et al. 2017). To defeat the above-mentioned defects, the synthesizing of electrode materials via coating very conductive materials onto active materials has shown to be sufficient (Wang et al. 2017a). To date, conductive polymers, owing to their excellent electrical conductivity, plasticity and simple fabrication display effective properties when working as electrode materials (Huang et al. 2016b). Yi et al. (2020) reported a rational study and the structure of Ni-oxide@ nickel molybdate likeporous sphere coated with polypyrrole. The outcomes reveal that the shell of nickel molybdate and polypyrrole with high electronic conductivity reduces the charge-transfer reaction resistance of Ni-oxide and then increases the electrochemical kinetics of Ni-oxide. The initial capacitance of Ni-oxide/ nickel molybdate/polypyrrole is $941.6 \mathrm{~F} \mathrm{~g}^{-1}$ at $20 \mathrm{~A} \mathrm{~g}^{-1}$. Particularly, the electrode holds capacitance of $850.2 \mathrm{~F} \mathrm{~g}^{-1}$ and remains $655.2 \mathrm{~F} \mathrm{~g}^{-1}$ with high retention of $77.1 \%$ at $30 \mathrm{~A} \mathrm{~g}^{-1}$ even after 30,000 cycles.

\section{Cobalt molybdate $\mathrm{CoMoO}_{4}$ nanoparticles}

Cobalt molybdate $\mathrm{CoMoO}_{4}$ has many advantages like nickel molybdate, such as cost-effectiveness, eco-friendliness and high electrochemical performance (Mai et al. 2011a). The considerable stability of one-dimensional form $\mathrm{CoMoO}_{4}$ like-nanorods structure exhibited exceptional stability with high specific capacitance (Liu et al. 2013b). The synthesized $\mathrm{CoMoO}_{4}$ by a simple sonochemical technique gave electrochemical performance and capacity of $\sim 133 \mathrm{~F} \mathrm{~g}^{-1}$ at $1 \mathrm{~mA} \mathrm{~cm}{ }^{-2}$ of current density (Veerasubramani et al. 2014). Furthermore, the $\mathrm{CoMoO}_{4}$ like-nanoplate arrays produced a maximum capacity of $227 \mu \mathrm{A} \mathrm{h} \mathrm{cm}^{-2}$ at $2.5 \mathrm{~mA} \mathrm{~cm}^{-2}$ and showed superior cyclic stability and energy density in the operating voltage window of $1.5 \mathrm{~V}$ (Veerasubramani et al. 2016). Nevertheless, metal oxides naturally have a short diffusion distance of electrolytes that resulted in lower electrical conductivity and restricted their application as electrodes for pseudocapacitors. High surface area and electrical conductivity of graphene material enable it to be used as an electrode for supercapacitor (Sun et al. 2011). Nevertheless, graphene supercapacitors have low energy density and restrict its usage in several significant applications. The obtained $\mathrm{CoMoO}_{4} @$ graphene composites possessed high electroactive areas which could promote accessible accession of $\mathrm{OH}^{-}$ions and quick charge carriers (Xia et al. 2013). Jinlong et al. (2017) have reported the synthesizing of $\mathrm{CoMoO}_{4} @$ reduced graphene-oxide nanocomposites via the hydrothermal method. The electrode nanocomposites electrode showed a remarkable capacity about of $\sim 856 \mathrm{~F} \mathrm{~g}^{-1}$ at $1 \mathrm{~A} \mathrm{~g}^{-1}$ and retain about $94.5 \%$ of its original capacitance over 2000 cycles. The electrode nanocomposites presented high electrochemical conductivity compared to pristine $\mathrm{CoMoO}_{4}$. This improvement is attributed to the obtained composites that had a greater specific surface area and average pore size than the pristine for nanoparticles of $\mathrm{CoMoO}_{4}$. The $\mathrm{CoMoO}_{4}$ like-nanoflake promoted electrolyte transport through the charging/discharging process and presented numerous active sites available for electrochemical reactions. The synergetic effect between reduced grapheneoxide and $\mathrm{CoMoO}_{4}$ also increased the performance of the supercapacitor.

\section{Iron(II) molybdate $\mathrm{FeMoO}_{4}$}

Iron(II) molybdate $\mathrm{FeMoO}_{4}$ is a part of the several notable mineral molybdates and assumed to give higher redox chemistry attributed to the mixed combinations of both $\mathrm{Fe}$ and Mo cations. To the day, Iron(II) molybdate widely utilized as promising electrode toward Li-ion batteries (Wang et al. 2014b). Wang et al. (2014b) have reported the doping of Iron(II) molybdate with graphene via a simple hydrothermal. The results confirmed that the Iron(II) molybdate/reduced graphene-oxide composite possesses specific capacitance $135 \mathrm{~F} \mathrm{~g}^{-1}$ at $1 \mathrm{~A} \mathrm{~g}^{-1}$ larger than those obtained of Iron(II) molybdate $96 \mathrm{~F} \mathrm{~g}^{-1}$ or reduced graphene-oxide $66 \mathrm{~F} \mathrm{~g}^{-1}$. Furthermore, the capacitance of the composite decayed gradually and reached $29.6 \%$ loss after 500 cycles. Recently, Nam et al. (2020) have successfully synthesized FMO nanosheet via the chemical bath deposition procedure. The outcomes demonstrate that the FMO electrode is highly proper in the supercapacitor application. The Iron(II) molybdate electrode shows excellent electrochemical achievements with specific capacity of about $158 \mathrm{~mA} \mathrm{~h} \mathrm{~g}^{-1}$ at $2 \mathrm{~A} \mathrm{~g}^{-1}$, and $9 \%$ loss of its original capacitance over $4 \times 10^{3}$ cycle.

\section{Spinel cobaltites}

Until now, significant research has been conducted and led to the promotion of spinel cobalt oxide $\mathrm{Co}_{3} \mathrm{O}_{4}$ because of its cost-effective components, original plenty, excellent redox ability and extraordinary theoretical specific capacitance (Zhai et al. 2017). Nevertheless, due to the high electrical resistivity as a result of its semiconducting nature, the electrochemical achievements of most published $\mathrm{Co}_{3} \mathrm{O}_{4}$ electrodes are still far from expectations, with restricted specific capacitances and moderate power densities ( $\mathrm{Lu}$ et al. 2017; Zhang et al. 2015a). Hence, considerable effort is being focused on offering more eco-friendly and moderately affordable alternative metals to partially substitute Co for making ternary spinel cobaltites, to collaboratively give excellent reversible capacities, preferred electrical conductivity and interesting redox chemistry (Liu et al. 2016a; Hui 
et al. 2016). Intrinsically, $\mathrm{Co}_{3} \mathrm{O}_{4}$ is characterized as a normal spinel structure, in which the $\mathrm{Co}^{2+}$ and $\mathrm{Co}^{3+}$ ions occupy the A-site and B-site, respectively (Gao et al. 2016a). The partially substituting $\mathrm{Co}$ by the transition metals (i.e., $\mathrm{Zn}, \mathrm{Mn}$, $\mathrm{Ni}$, and $\mathrm{Cu}$ ) in the $\mathrm{Co}_{3} \mathrm{O}_{4}$ lattice leads to produce an inverse spinel structure, in which the external cation occupies the B-sites, while Co occupies both the A- and B-sites (Kim et al. 2014). This presents effective channels for ion diffusion enrichment toward charge carriers (electrons or holes) that jump into the A-site and B-site for high electrical conduction (Liu et al. 2018b).

\section{Nickel cobaltite $\left(\mathrm{NiCO}_{2} \mathrm{O}_{4}\right)$}

$\mathrm{NiCo}_{2} \mathrm{O}_{4}$ as a mineral oxide represents a proper candidate used in the energy storage area owing to a high special capacity, extraordinary electric conduction and excellent stability (Xu et al. 2018a; Yuan et al. 2020). The nanoparticles of nickel-cobaltite were initially published as an exceptional display electrode candidate for electrochemical capacitors (Wei et al. 2010). Consequently, several nickel-cobaltite structures with various morphologies exhibited increased capacitive achievements as opposed to the bulk structure. Searches on Web of Science have revealed that about 1000 articles related to the application of nickel-cobaltite materials for electrochemical capacitors have been published to date. The composites of the nanoparticles of nickel-cobaltite originated on a substrate owns conduction nature is utilized in capacitors applications. Current research has confirmed that the incorporation of different elements upon the nanoparticles of nickel-cobaltite leading to achieving the excellent capacity and durability of the nanoparticles of nickelcobaltite (Lin and Lin 2017). This performance-enhanced electrochemical property of the nanoparticles of nickelcobaltite because attributing to production more transportation channels to easy charges motion leading to improve its electric conduction (Cheng et al. 2020b).

The nanoparticles of the spinel nickel-cobaltite own inverse structure where $\mathrm{Ni}^{2+}$ cations settle the $\mathrm{B}$-sites and $\mathrm{Co}^{2+}$ ions settle the B- and A-sites equally. The nanoparticles of spinel nickel-cobaltite, a semiconductor (p-type) owns narrow bandgap $(\sim 2.1 \mathrm{eV})$ with suitable electric conduction. Spinel nickel-cobaltite has excited many researchers due to its promising cost-effectiveness and eco-friendliness properties compared with other metals oxides materials. The basic reactions can be displayed as the next equations (Cheng et al. 2020b):

$$
\begin{aligned}
& \mathrm{NiCo}_{2} \mathrm{O}_{4}+\mathrm{OH}^{-}+\mathrm{H}_{2} \mathrm{O} \Leftrightarrow \mathrm{NiOOH}+2 \mathrm{CoOOH}+\mathrm{e}^{-} \\
& 2 \mathrm{CoOOH}+\mathrm{OH}^{-} \Leftrightarrow \mathrm{CoO}_{2}+\mathrm{H}_{2} \mathrm{O}+\mathrm{e}^{-}
\end{aligned}
$$

Through the charge-discharge cycle, the redox reactions only appear on the surface of the electrode materials. It was observed that the specific capacitance of the spinel nickelcobaltite improved after many hundreds of cycles to a limit range, owing to its exceptional morphologies and the activation process of the electrode (Cheng et al. 2020b).

Yang et al. (2019b) have synthesized the nanoparticles of spinel nickel-cobaltite with nanoneedle morphology via the hydrothermal technique. The nanoneedle of spinel nickelcobaltite changed to nanoflake morphology via a template on the surface of a self-assembly graphene oxide/multiwall carbon nanotube. The template/substrate worked as a seed layer to promote the production of nucleation sites to facilitate the nanoparticles of spinel nickel-cobaltite to build on the surface of the template/substrate, through promoting the nanoneedle-like array morphology. The electrode composite showed extraordinary specific capacitance of $1525 \mathrm{~F} \mathrm{~g}^{-1}$ at $1 \mathrm{~A} \mathrm{~g}^{-1}$ and $1081 \mathrm{~F} \mathrm{~g}^{-1}$ at $100 \mathrm{~A} \mathrm{~g}^{-1}$, respectively. The prepared composite electrodes were utilized as both the anode and cathode, the supercapacitor showed the highest power density and maximum energy density of $5151 \mathrm{~W} \mathrm{~kg}^{-1}$ and $25.2 \mathrm{~W} \mathrm{~h} \mathrm{~kg}^{-1}$, respectively. Besides, is displayed superior cycling stability, where lost $0.4 \%$ only of the primary capacitance over $7 \times 10^{3}$ cycle thus affirming its suite for supercapacitor applications.

Both the nanoparticles of spinel nickel-cobaltite and $\mathrm{MnO}_{2}$ have an edge owing to their characteristic abundance in nature, high theoretical capacitance and cost-effectiveness (Yuan et al. 2017). Xu et al. (2018a) first published that the hierarchical nanoparticles of spinel nickel-cobaltite@manganese dioxide core-shell nanowire arrays showed exceptional characteristics for electrochemical capacitors. The excellent performance was associated with the significant core-shell form and the synergistic impacts of the mixed enrichment from the porous nanoparticles of spinel nickelcobaltite core and the thin manganese dioxide shell. Also, Zhang et al. (2016a) utilized galvanostatic electrodeposition to attach manganese dioxide nanoflakes on a two-dimensional form of the nanoparticles of spinel nickel-cobaltite structures on the steel mesh outside. The studied electrode offers a specific capacitance with a value of $914 \mathrm{~F} \mathrm{~g}^{-1}$ at $0.5 \mathrm{~A} \mathrm{~g}^{-1}$ along with after 3000 cycles has a loss of $12.9 \%$.

\section{Zinc cobaltite $\mathrm{ZnCO}_{2} \mathrm{O}_{4}$}

Spinel-type $\mathrm{ZnCo}_{2} \mathrm{O}_{4}$ is one of the spinel transition oxide group and characteristic cobaltite with $\mathrm{Zn}^{2+}$ ions locating the A-sites of spinel $\mathrm{Co}_{3} \mathrm{O}_{4}$ (Wu et al. 2015a). The ecofriendly, low-priced and abundant $\mathrm{Zn}$, Co atoms show the high electrochemical activities; therefore, it is strongly applied in energy storage applications. Zhou et al. reported one-dimensional from the spinel-type $\mathrm{ZnCo}_{2} \mathrm{O}_{4}$ porous nanotubes which exhibit an extraordinary specific capacitance of $770 \mathrm{~F} \mathrm{~g}^{-1}$ at $10 \mathrm{~A} \mathrm{~g}^{-1}$ (Zhou et al. 2014). Also, Venkatachalam et al. (2017) used a hydrothermal technique to 
prepare the spinel-type $\mathrm{ZnCo}_{2} \mathrm{O}_{4}$ like-hexagonal nanostructured, showing $845.7 \mathrm{~F} \mathrm{~g}^{-1}$ at a current density of $1 \mathrm{~A} \mathrm{~g}^{-1}$. Finally, Kathalingam et al. (2020) prepared the spinel-type $\mathrm{ZnCo}_{2} \mathrm{O}_{4} @$ Nitrogen-doped-graphene oxide/polyaniline hybrid nanocomposite via a hydrothermal approach. The highest specific capacitance was $720 \mathrm{~F} \mathrm{~g}^{-1}$ at $10 \mathrm{mV} \mathrm{s}^{-1}$ and $96.4 \%$ capacity retention after $10^{4}$ cycles were achieved. This enhanced performance for the composite electrode was ascribed to the improvements from reinforced material porosity characteristics.

The underlying mechanism of this action influenced by various cation substitutions $(\mathrm{Mn}, \mathrm{Ni}$, and $\mathrm{Cu}$ ) has been discussed (Fig. 6). Liu et al. (2018b) presented a systematic examination to clarify the impact of metals replacement on the pseudocapacitive performance of spinel $\mathrm{Co}_{3} \mathrm{O}_{4}$. The replacement of $\mathrm{Co}$ by transition metals in the $\mathrm{Co}_{3} \mathrm{O}_{4}$ lattice can concurrently increase charge transference and ion dispersion, that way showing improved electrochemical properties. The $\mathrm{MnCo}_{2} \mathrm{O}_{4}$ gives magnificent specific capacitance about $\left(\sim 2145 \mathrm{~F} \mathrm{~g}^{-1}\right)$ at $1 \mathrm{~A} \mathrm{~g}^{-1}$. Also, more than $92 \%$ of its primary capacitance is kept after $5 \times 10^{3}$ cycles. Besides, the $\mathrm{MnCo}_{2} \mathrm{O}_{4}$ /activated carbon electrode produces an exceptional energy density ( $\sim 56 \mathrm{~W} \mathrm{~h} \mathrm{~kg}$ ) at a power density of about $800 \mathrm{~W} \mathrm{~kg}^{-1}$.

\section{Inorganic perovskite-type oxides}

The inorganic perovskite-type oxides show special physicochemical characteristics in ferroelectricity (Pontes et al. 2017; Rana et al. 2020; Cao et al. 2017), piezoelectricity (Perumal et al. 2019; Vu et al. 2015; Xie et al. 2019), dielectric (Arshad et al. 2020; Zhou et al. 2019; Boudad et al. 2019), ferromagnetism (Yakout et al. 2019; Ravi and
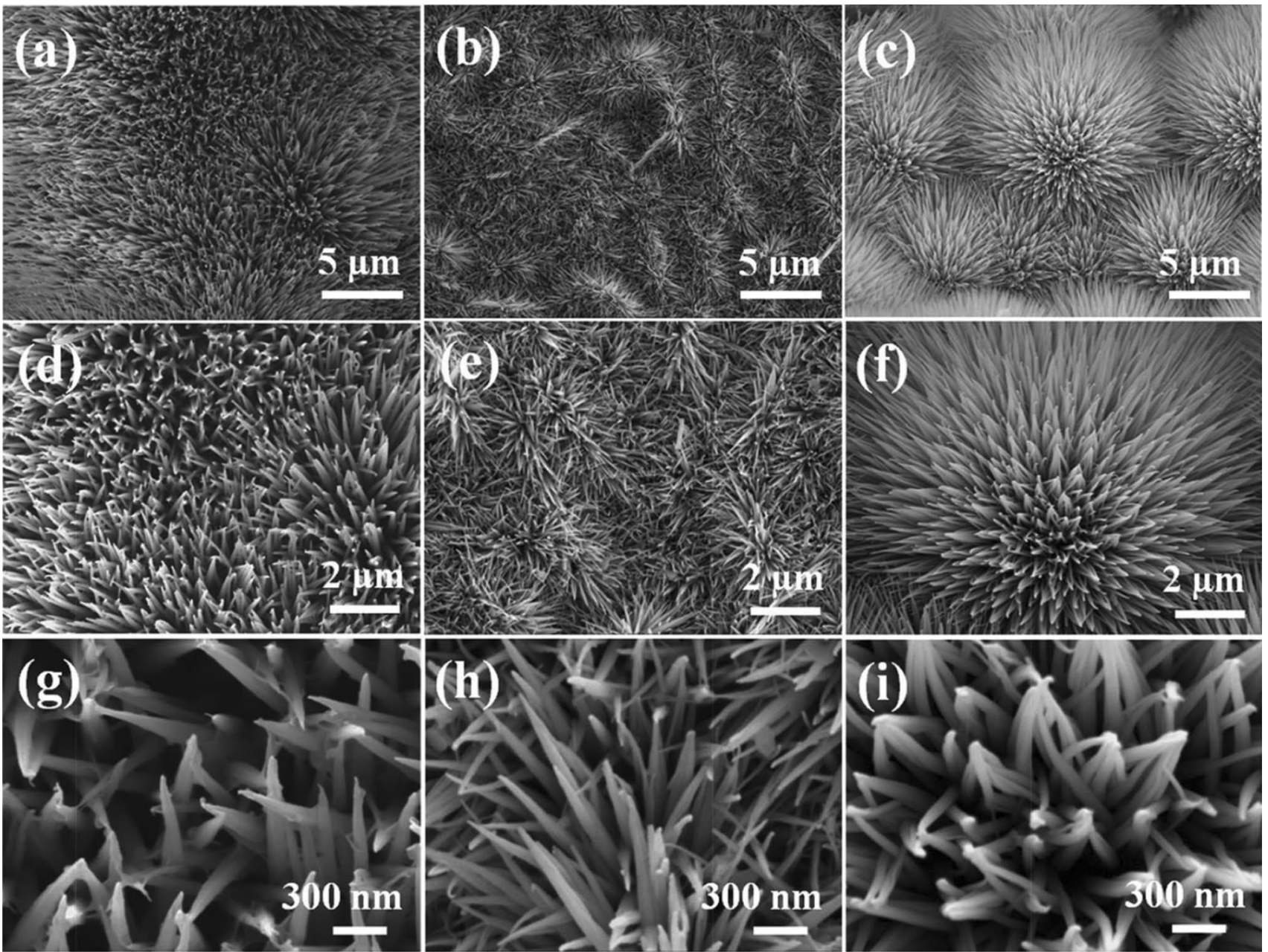

Fig. 6 This figure exhibits that the $\mathrm{MCO}_{2} \mathrm{O}_{4}$ nanowires are completely segregated with the symmetrical arrangement, which could be useful to the ions transport to redox-active positions, then probably enhancing the electrochemical features. The images of the field-emission scanning electron microscopy (FESEM) of $\mathbf{a}, \mathbf{d}, \mathbf{g ~} \mathrm{MnCo}_{2} \mathrm{O}_{4}, \mathbf{b}, \mathbf{e}, \mathbf{h}$ $\mathrm{NiCo}_{2} \mathrm{O}_{4}$, and $\mathbf{c}, \mathbf{f}, \mathbf{i} \mathrm{CuCo}_{2} \mathrm{O}_{4}$ nanowires at different magnifications. Adapted with permission from Liu et al. (2018b). Copyright 2018, Royal Society of chemistry 
Senthilkumar 2017; Alvarez et al. 2016), magnetoresistance (Wang et al. 2015a; Liu et al. 2007; Dwivedi et al. 2015), and multiferroic (Li et al. 2019b; Zhang et al. 2016b; Pedro-García et al. 2019). They are interesting nanomaterials for broad applications in catalysis (Grabowska 2016; Yang and Guo 2018; Hwang et al. 2019; Xu et al. 2019a; Ramos-Sanchez et al. 2020), fuel cells (Kaur and Singh 2019; Sunarso et al. 2017; Jiang 2019), ferroelectric random access memory (Gao et al. 2020; Chen et al. 2016a; Wang et al. 2019a), electrochemical sensing and actuators (Govindasamy et al. 2019a; Deganello et al. 2016; Atta et al. 2019; Zhang and Yi 2018; Rosa Silva et al. 2019), and supercapacitors (Song et al. 2020; Salguero Salas et al. 2019; Lang et al. 2019; George et al. 2018). Furthermore, these materials possess a significant advantage that is the simple crystalline structure and low cost for the preparation of these materials in monocrystalline or polycrystalline form. Any small modification of their typical crystal structure and chemical composition may lead to the production of unique transport (Choudhary et al. 2020), magnetic (Abbas et al. 2019), catalytic (Abirami et al. 2020), thermochemical (Gokon et al. 2019), mechanical(Wang et al. 2016a), and electrochemical (Baharuddin et al. 2019) properties. Recently, increased efforts have taken place by research groups worldwide concentrating on optimizing the physical properties of perovskite-structured compounds. Most investigations are based on confirming a correlation between the crystalline structure and the chemical stoichiometry of the major components. These have led to an enhancement in the functional properties of the perovskites (Rendón-Angeles et al. 2016).

The atomic arrangement for perovskites originally related to the prototype mineral perovskite, $\mathrm{CaTiO}_{3}$, with the formula $\mathrm{ABO}_{3}$, where $\mathrm{B}$ is a small transition mineral cation and $\mathrm{A}$ is larger. It was assumed that the unit cell of $\mathrm{CaTiO}_{3}$ could be interpreted by $\mathrm{Ca}^{2+}$ ions at the corners of a cube, with $\mathrm{Ti}^{4+}$ ions at the body center and $\mathrm{O}^{2-}$ ions at the center of the faces (Schaak and Mallouk 2002).

To illustrate the correlation between the $\mathrm{A}, \mathrm{B}$, and $\mathrm{O}$ ions, the typical $\mathrm{ABO}_{3}$ perovskite possesses a cubic crystal structure with tolerance factor $(\tau)=1$, which is represented as $\tau=\left(r_{\mathrm{A}}+r_{\mathrm{O}}\right) / \sqrt{ } 2\left(r_{\mathrm{B}}+r_{\mathrm{O}}\right)$, where $r_{\mathrm{A}}, r_{\mathrm{B}}$ and $r_{\mathrm{O}}$ are the ionic radii of $\mathrm{A}, \mathrm{B}$ and oxygen elements, respectively. Goldschmidt has revealed that the cubic perovskite structure is stable only in tolerance factor a close range of $0.8<\tau<0.9$, and a slightly larger range for distorted perovskite structures with orthorhombic or rhombohedral symmetry. The replacement of multiple cations into the A- or B-sites can change the symmetry of the pristine structure and, consequently, the physical and chemical properties (Zhang et al. 2016c). These changes in symmetry can be fulfilled over relatively little disfigurement in the crystal structure. This is evident in compounds that have smaller and larger values, leading to tilting of the $\mathrm{BO}_{6}$ octahedral to permeate space. For orthorhombic structures, the tilting is about the $\mathrm{b}$ and $\mathrm{c}$ axes and for rhombohedral structures, the tilting is about each axis. This tilting brings the decrease in coordination number for A, B or both ions. In addition to tilting, displacement of cations can also lead to structural distortion.

The structure of rare-earth manganites $\mathrm{RMnO}_{3}$ perovskite ( $\mathrm{R}=$ rare earth element $)$ is widely affected via the internal structural distortions existing in the compound (Chen et al. 2007; Dabrowski et al. 2005). The structure is formed by inter-combined $\mathrm{MnO}_{6}$ octahedra in rare-earth. Usually, the lattice of perovskite lattice has distorted due to (1) octahedral tilting and/or (2) Jahn-Teller deformation (Siwach et al. 2008). Nandy et al. (2017) reported the influence of $\mathrm{Na}^{+}$substituting on internal lattice deformation of $\mathrm{EuMnO}_{3}$. The common atomic order of $\mathrm{Eu}_{1-x} \mathrm{Na}_{x} \mathrm{MnO}_{3}$ samples is presented in Fig. 7. It is obvious that 6 atoms of oxygen settle in face-centered of the cubic and 1 manganese atom settle body-centered of the cubic outlines the $\mathrm{MnO}_{6}$ octahedra; finally, the corners were occupied via both of europium and sodium atoms. The lattice is exposed to deformations via the octahedra $\mathrm{MnO}_{6}$ tilting and Jahn-Teller effect. The possibility for various replacements at the site of the cations is the principal feature of perovskites, which results in the appearance of great groups of compounds with different cations in $\mathrm{B}$ site $\left(\mathrm{AB}_{x} \mathrm{~B}_{1-\mathrm{x}} \mathrm{O}_{3}\right)$; with various cations in $\mathrm{A}$ site $\left(\mathrm{A}_{x} \mathrm{~A}_{1-x} \mathrm{BO}_{3}\right)$; and with replacements in both cation position $\left(\mathrm{A}_{x} \mathrm{~A}_{1-x} \mathrm{~B}_{\mathrm{y}} \mathrm{B}_{1-y} \mathrm{O}_{3}\right)$ (Assirey 2019).

The phases of perovskite oxides have been classified into 2 categories (Assirey 2019):

I. The ternary perovskite-type oxides are divided into $\mathrm{A}^{1+} \mathrm{B}^{5+} \mathrm{O}_{3}, \mathrm{~A}^{2+} \mathrm{B}^{4+} \mathrm{O}_{3}, \mathrm{~A}^{3+} \mathrm{B}^{3+} \mathrm{O}_{3}$ types and oxygen- and cation-deficient phases. The oxygen and cation-deficient phases will be regarded as those which include large vacancies and not phases which are only slightly non-stoichiometric. Several of these hold B ions of one element in two valence states and should not be confused with the complex perovskite compounds which contain different elements in various valence states (Assirey 2019; Pan and Zhu 2016; Galasso 2013).

II. The complex perovskite-type compounds $\mathrm{A}\left(\mathrm{B}_{x}^{\prime} \mathrm{B}_{y}^{\prime \prime}\right) \mathrm{O}_{3}$ will be classified into four compounds which contain (Galasso 2013; Modeshia and Walton 2010):

(a) Compounds possess twice as much lower valence state elements as higher valence state elements, $\mathrm{A}\left(\mathrm{B}_{0.67}^{\prime} \mathrm{B}_{0.33}^{\prime \prime}\right) \mathrm{O}_{3}$.

(b) Compounds possess twice as much higher valence state elements as lower valence state elements, $\mathrm{A}\left(\mathrm{B}_{0.33}^{\prime} \mathrm{B}_{0.67}^{\prime \prime}\right) \mathrm{O}_{3}$. 
(a)

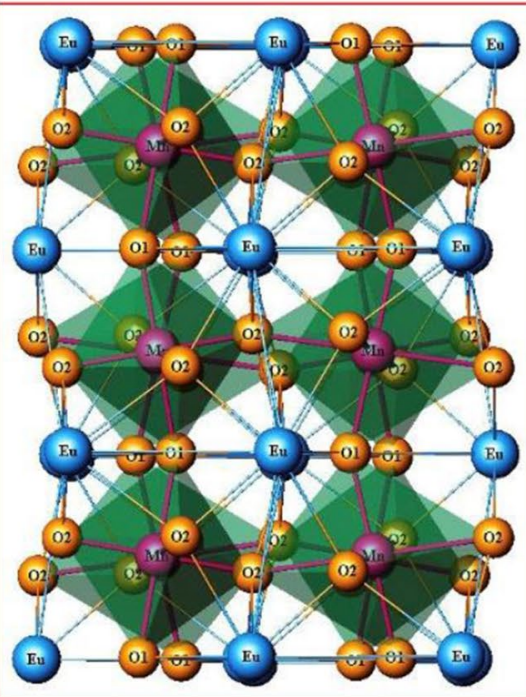

(b)

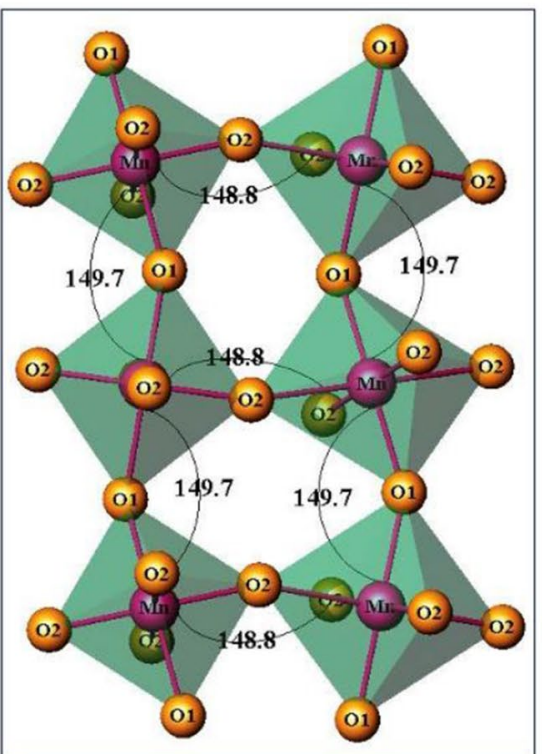

(c)

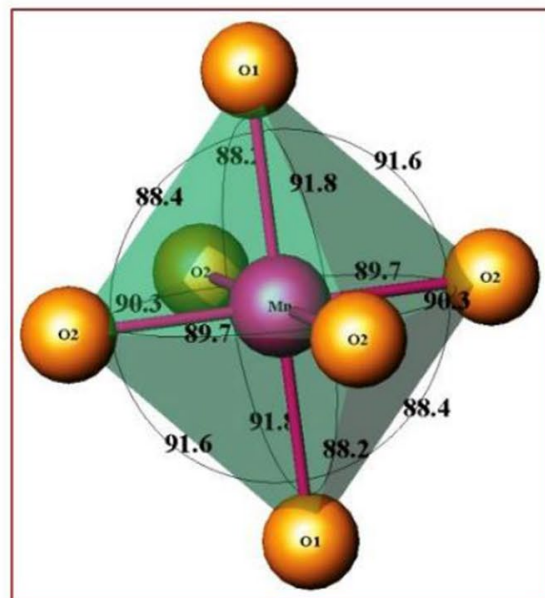

$\mathrm{x}=0.00$
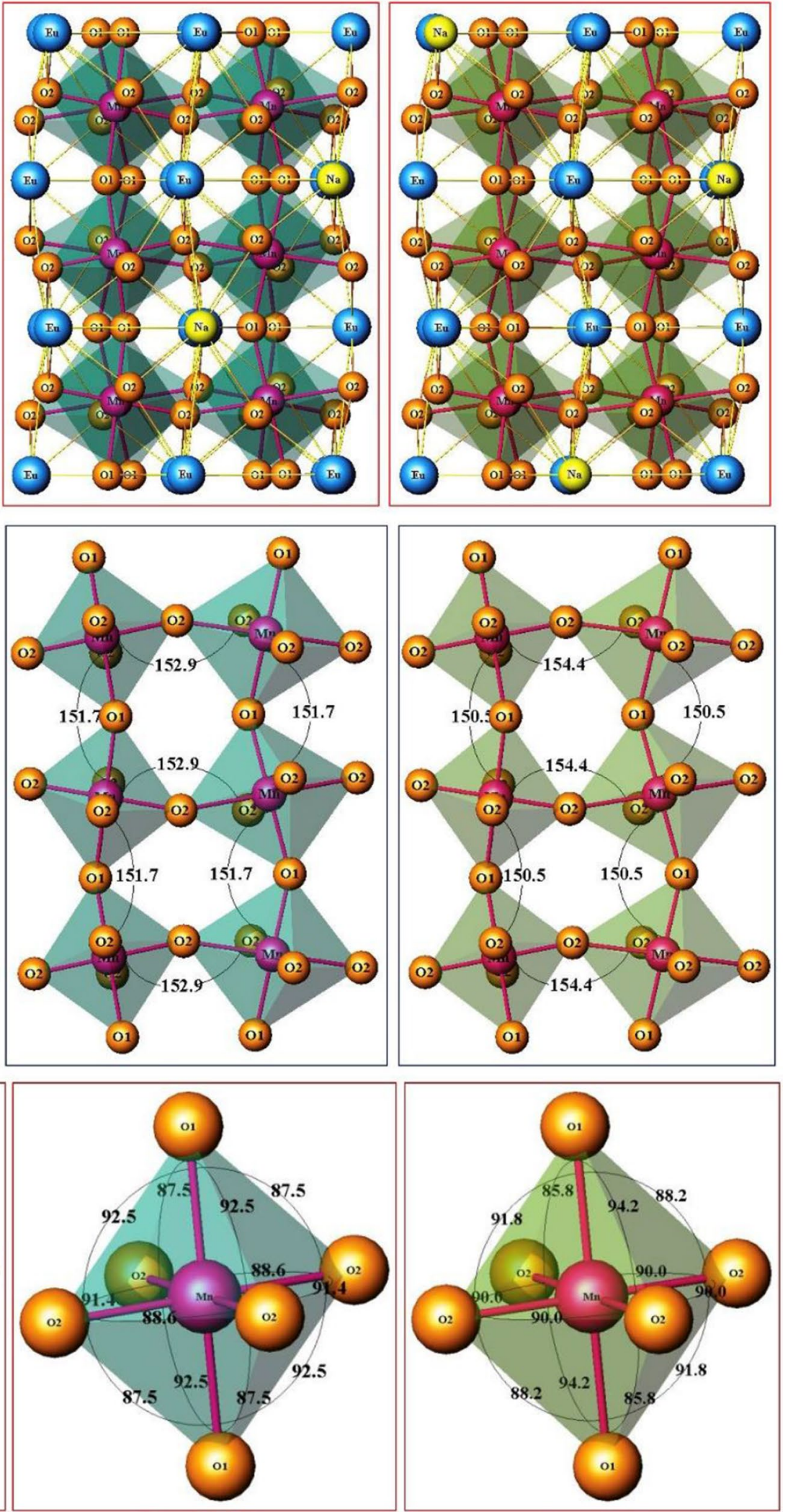

$x=0.10$

$x=0.20$ 
4Fig. 7 a, b $\mathrm{MnO}_{6}$ tilting arrangement of atoms and combining c angles between asymmetrical bond $\mathrm{Eu}_{1-x} \mathrm{Na}_{x} \mathrm{MnO}_{3}$ samples, it is obvious that 6 atoms of oxygen settle in face-centered of the cubic and 1 manganese atom settle body-centered of the cubic outlines the $\mathrm{MnO}_{6}$ octahedra, finally the corners were occupied via both of europium and sodium atoms. Adapted with permission from Nandy et al. (2017). Copyright 2017, Elsevier

(c) Compounds possess equal proportions of the two B elements, $\mathrm{A}\left(\mathrm{B}_{0.5}^{\prime} \mathrm{B}_{0.5}^{\prime \prime}\right) \mathrm{O}_{3}$.

(d) Compounds with oxygen-deficient phases, $\mathrm{A}\left(\mathrm{B}_{x}^{\prime} \mathrm{B}_{y}\right) \mathrm{O}_{3-z}$.

Potassium niobate $\left(\mathrm{KNbO}_{3}\right)$ presents various crystal arrangements depending on temperature, as compiled in Fig. 8. Above its curie temperature $T_{\mathrm{C}}=708 \mathrm{~K}$, it loses its ferroelectric properties and becomes cubic. While, below its curie temperature, it exhibits tetragonal, orthorhombic and then rhombohedral lattice with a reduction in temperature (Grabowska 2016; Zhang et al. 2013a, 2016c; Hirel et al. 2015).

$\mathrm{KNbO}_{3}$ in orthorhombic phase has lattice parameters: $a=3.973, b=5.693$, and $c=5.721 \AA$ belongs space group Amm2, cubic phase $\mathrm{KNbO}_{3}$ has lattice parameter of $a=4.022 \AA$ with space group (Pm3m), while $\mathrm{KNbO}_{3}$ tetragonal phase belongs to space group (P4mm) (Magrez et al. 2006).

As a promising and crucial device for energy storage/ conversion, supercapacitors have gained interest and wide appeal owing to its fast charge and discharge cycle, longlasting lifecycle, high power density and safe operation (Lang et al. 2017). Investigating unique electrode materials, particularly coating electrodes with conductive matter is one of the most impactful ideas to enhance conductivity. It was not until 2014 before studies on perovskites as anodes for supercapacitors emanated when Mefford et al. (2014) examined the electrochemical properties $\mathrm{LaMnO}_{3}$ for supercapacitors and suggested oxygen-anion-intercalation as the mechanism that charge storage depends upon. Besides, in toward supercapacitors and hybrid supercapacitors, the perovskites have some edge when utilized as anodes. Where they have a great significance of oxygen vacancies, i.e., they have a mineral character in the ground state due to B cations $3 d$ and $\mathrm{O} 2 p$ orbitals through the Fermi level among the total density of states (Liu et al. 2018c). Hence, the immense content of oxygen vacancies $\left(\mathrm{O}_{\text {vacancy }}\right)$, and remarkable conductivity allows their extraordinary energy densities. Also, the perovskites store charge by oxygen intercalation and the excellent diffusion pathways along crystal domain boundaries leading the promotion of the dispersion rate (Nan et al. 2019).

The La-based perovskite oxides were observed to possess numerous merits like heightened electronic conduction, broad window of voltage and excellent stability of charge/ discharge pathway. A well-known procedure to increase the electronic conduction (or decrease the resistance) of composite-based on $\mathrm{LaBO}_{3}$ perovskites is through the completely/or partial incorporation of diverse cations $\left(\mathrm{Ca}^{2+}, \mathrm{Sr}^{2+}\right.$ etc.) for $\mathrm{La}^{3+}$ species on A-site, leading to a larger number of oxygen vacancies are inserted in the structure (Nan et al. 2019; $\mathrm{Ma}$ et al. 2020). For $\mathrm{LaMnO}_{3}$ perovskite, the charge imbalance after the substitution is partially offset through the oxidation of $\mathrm{Mn}^{3+}$ species $\left(d^{4}\right)$ to $\mathrm{Mn}^{4+}$ oxide species $\left(d^{3}\right)$ in the B-site, jointly with the Jahn-Teller effect of manganese $\left(\mathrm{Mn}^{3+}\right)$ ion species, attending to the perovskite structure deformation (Louca et al. 1997). The structure of the perovskite is assumed to possess a significant impact on the $\mathrm{O}_{\text {vacancy }}$ concentration, the $\mathrm{O}^{2-}$ diffusivity, along with the electrochemical behavior (Liu et al. 2016b).

Hence, future research should pay more attention to the quantity of $\mathrm{O}_{\text {vacancy }}$ required (Nan et al. 2019). The studies of the possibility of applying the perovskite oxides in supercapacitors were insufficient. Thus, in the next section, the impact of cation substitution on perovskite supercapacitors, and consequently, the changes in their electrochemical performance was reviewed.

\section{Influence of cation substitution in A-site of perovskite oxides}

Ma et al. (2020) have examined the influence of A-site substitution of $\mathrm{LaMnO}_{3}$ perovskite via calcium ions $\left(\mathrm{Ca}^{2+}\right)$ or strontium $\left(\mathrm{Sr}^{2+}\right)$. The $\mathrm{La}_{0.85} \mathrm{Ca}_{0.15} \mathrm{MnO}_{3}$ and $\mathrm{La}_{0.85} \mathrm{Sr}_{0.15} \mathrm{MnO}_{3}$ samples are synthesized via the sol-gel method. Schematic diagrams of the oxygen intercalation process in the phases of the crystal structure (orthorhombic/rhombohedral) of the studies samples are offered in Fig. 9. The relation between the oxygen octahedron deformity and Jahn-Teller impact as illustrated above as Mefford detailed, $\mathrm{R} 1$ has illustrated the oxidation pathway of $\left(\mathrm{Mn}^{2+}\right)$ to $\left(\mathrm{Mn}^{3+}\right)$. One of $\mathrm{O}_{\text {vacancy }}$ is fulfilled by $\mathrm{O}^{2-}$ intercalation, collectively with 2 ions of $\mathrm{Mn}^{2+}$ oxidized to $\mathrm{Mn}^{3+}$ as shown in the following equation:

$$
\begin{aligned}
& \mathrm{La}_{0.85} \mathrm{~A}_{0.15}\left[\mathrm{Mn}_{2 \delta}^{2+} ; \mathrm{Mn}_{1-2 \delta}^{3+}\right] 0_{2.925-\delta}+2 \delta 0 \mathrm{H}^{-} \\
& \leftrightarrow \mathrm{La}_{0.85} \mathrm{~A}_{0.15} \mathrm{Mn}^{3+} \mathrm{O}_{2.925}+2 \delta \mathrm{e}^{-}+\delta \mathrm{H}_{2} \mathrm{O}
\end{aligned}
$$

Nevertheless, the variation is that the $\mathrm{La}_{0.85} \mathrm{~A}_{0.15} \mathrm{Mn}^{3+} \mathrm{O}_{2.925}$ is yet shown as an oxygen-deficient when every of the $\mathrm{Mn}^{2+}$ are oxidized to $\mathrm{Mn}^{3+}$. Therefore, the following step which expects the oxidation process of $\mathrm{Mn}^{3+}$ to $\mathrm{Mn}^{4+}$ as shown in the next equation:

$$
\begin{aligned}
& \mathrm{La}_{0.85} \mathrm{~A}_{0.15} \mathrm{Mn}^{3+} \mathrm{O}_{2.925}+2 \delta 0 \mathrm{H}^{-} \\
& \quad \leftrightarrow \mathrm{La}_{0.85} \mathrm{~A}_{0.15}\left[\mathrm{Mn}_{2 \delta}^{4+} ; \mathrm{Mn}_{1-2 \delta}^{3+}\right] 0_{2.925+\delta} \\
& \quad+2 \delta \mathrm{e}^{-}+\delta \mathrm{H}_{2} \mathrm{O}
\end{aligned}
$$




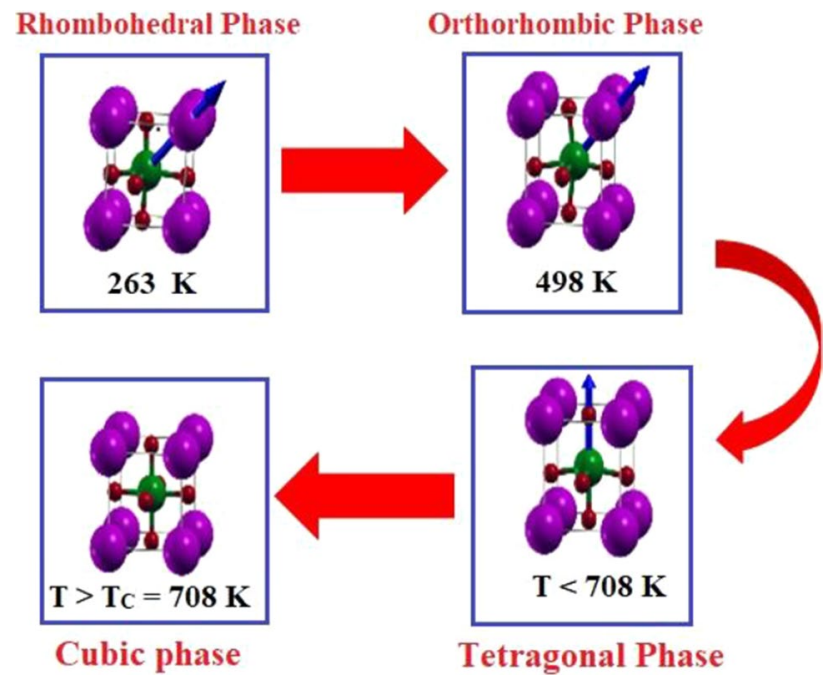

Fig. 8 Crystal structures of cubic, orthorhombic and tetragonal and rhombohedral $\mathrm{KNbO}_{3}$. Green spheres represent $\mathrm{Nb}$, red spheres represent oxygen and purple spheres represent K. Adapted with permission from Hirel et al. (2015)
The last step is classified into 2 steps. At $\delta=0.075$, it occurs through $\mathrm{O}^{2-}$ that continuously arrested to fulfil the residual $\mathrm{O}_{\text {vacancy, }}$, and the ions of $\mathrm{Mn}^{3+}$ are transformed into ions of $\mathrm{Mn}^{4+}$ (R2-1 in Fig. 9). The $\mathrm{O}_{\text {vacancy }}$ completely diffuses to the surface of the material, $\mathrm{La}_{0.85} \mathrm{~A}_{0.15}\left[\mathrm{Mn}_{0.15}^{4+} ; \mathrm{Mn}_{0.85}^{3+}\right] \mathrm{O}_{3}$ is formed. Then, the second step occurs, the $\mathrm{Mn}^{3+}$ ions are more transformed to $\mathrm{Mn}^{4+}$, appearing in the oxygen over abundance $\mathrm{La}_{0.85} \mathrm{~A}_{0.15}\left[\mathrm{Mn}_{2 \delta}^{4+} ; \mathrm{Mn}_{1-2 \delta}^{3+}\right] 0_{2.925+\delta}(\delta>0.075)$ product (R2-2 in Fig. 9).

Therefore, $\mathrm{La}_{0.85} \mathrm{Ca}_{0.15} \mathrm{MnO}_{3}$ and $\mathrm{La}_{0.85} \mathrm{Sr}_{0.15} \mathrm{MnO}_{3}$ samples with higher essential $\mathrm{O}_{\text {vacancy }}$ display excellent capacitance features than $\mathrm{LaMnO}_{3}$ and store more energy by the $\mathrm{O}_{\text {vacancy }}$ tailored redox pseudocapacitance. The capacitances achieved are $\sim 33.0 \mathrm{mF} \mathrm{cm}^{-2}, 129.0 \mathrm{mF} \mathrm{cm}^{-2}$, and $140.5 \mathrm{mF} \mathrm{cm}{ }^{-2}$ for $\mathrm{LaMnO}_{3}, \mathrm{La}_{0.85} \mathrm{Sr}_{0.15} \mathrm{MnO}_{3}$, and $\mathrm{La}_{0.85} \mathrm{Ca}_{0.15} \mathrm{MnO}_{3}$, respectively. The $\mathrm{La}_{0.85} \mathrm{Ca}_{0.15} \mathrm{MnO}_{3}$ electrode produces the most exceptional capacitance behavior due to the lower value of ion dispersion impedance, the most distinguished concentricity of $\mathrm{O}_{\text {vacancy }}$ and the sufficient exploitation of the perovskite bulk structure.

(a)

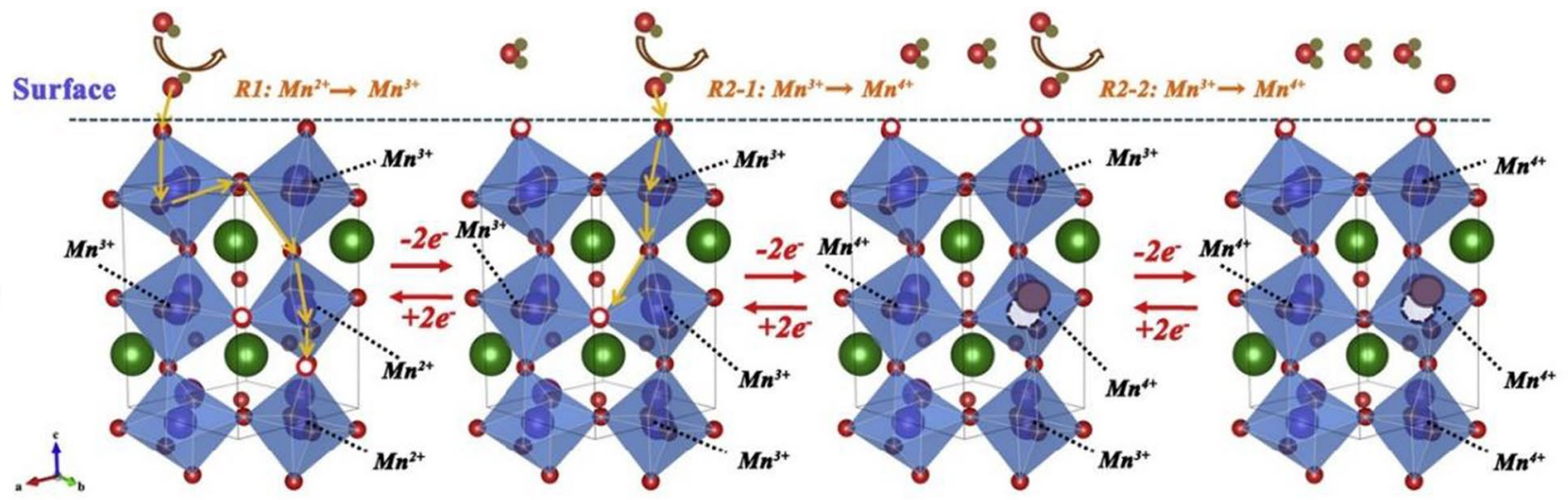

(b)

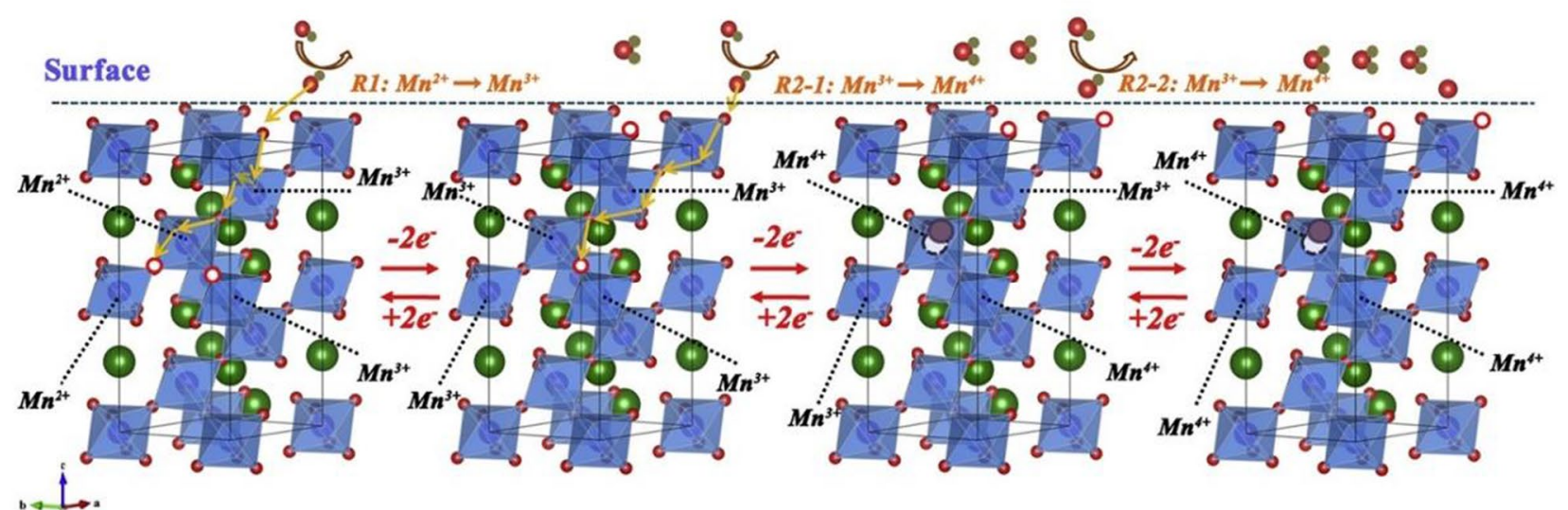

\section{$\boldsymbol{L a}$}

Fig. 9 a $\mathrm{La}_{0.85} \mathrm{Ca}_{0.15} \mathrm{MnO}_{3} ;$ b $\mathrm{La}_{0.85} \mathrm{Sr}_{0.15} \mathrm{MnO}_{3}$ compositions: the structures of crystal and the oxygen intercalation pathways of A-site replacement, the $\mathrm{La}_{0.85} \mathrm{Ca}_{0.15} \mathrm{MnO}_{3}$ and $\mathrm{La}_{0.85} \mathrm{Sr}_{0.15} \mathrm{MnO}_{3}$ samples with higher essential $\mathrm{O}_{\text {vacancy }}$ display excellent capacitance features than $\mathrm{LaMnO}_{3}$ and store more energy by the $\mathrm{O}_{\text {vacancy. }}$ Adapted with permission from Ma et al. (2020). Copyright 2020, Elsevier 
Also, Mo et al. (2018) have prepared Ca-doped perovskite lanthanum manganite via the sol-gel technique. Between fabricated samples, $\mathrm{La}_{0.5} \mathrm{Ca}_{0.5} \mathrm{MnO}_{3}$ exhibited low essential resistance of $2.13 \Omega \mathrm{cm}^{2}$ and an extraordinary specific surface area of $23.0 \mathrm{~m}^{2} \mathrm{~g}^{-1}$. The highest specific capacitance achieved was $170 \mathrm{~F} \mathrm{~g}^{-1}$ at $1 \mathrm{~A} \mathrm{~g}^{-1}$. Nevertheless, $\mathrm{La}-\mathrm{Ca}-\mathrm{MnO}_{3}$ met serious elements leaching, resulting in small cycling stabilities and thereby restricting their applications as electrode materials of supercapacitors. Therefore, Ca-doped lanthanum manganite samples were not attractive applicants for supercapacitor applications. Overall, developments in electrochemical performances of manganite electrodes need different effective techniques to prevent cations leaching in Ca-doped perovskite lanthanum manganite. Wang et al. (2019b) have fabricated nanofibers of $\mathrm{La}_{\mathrm{x}} \mathrm{Sr}_{1-x} \mathrm{FeO}_{3}$ oxides via combining electrospinning. As an outcome, they produced $\mathrm{La}_{0.7} \mathrm{Sr}_{0.3} \mathrm{FeO}_{3}$ nanofibers exhibiting outstanding performance as an electrode for supercapacitor purposes including increased specific surface area $\sim 28.0 \mathrm{~m}^{2} \mathrm{~g}^{-1}$ and efficient unique of the huge porosity. The $\mathrm{La}_{x} \mathrm{Sr}_{1-x} \mathrm{FeO}_{3}(x=0.3)$ NPs exhibited an extraordinary capacitance around $520 \mathrm{~F} \mathrm{~g}^{-1}$, which is still more than other samples. Additionally, over $5 \times 10^{3}$ cycles and at $20 \mathrm{~A} \mathrm{~g}^{-1}$, the $\mathrm{La}_{x} \mathrm{Sr}_{1-x} \mathrm{FeO}_{3}(x=0.3)$ owns superior rate strength and stability over cycling $(\sim 84 \%)$ of its primary capacitance. Also, Cao et al. (Cao et al. 2015a) have synthesized nanofibers of the nanoparticles of $\mathrm{La}_{x} \mathrm{Sr}_{1-x} \mathrm{Co}_{0.1} \mathrm{Mn}_{0.9} \mathrm{O}_{3-\delta}$ oxides via electrospinning technique. The authors examined the impact of Sr cation substitution in A-site. They found that strontium substitutes the site of La ions; therefore, the morphology of $\mathrm{La}_{x} \mathrm{Sr}_{1-x} \mathrm{Co}_{0.1} \mathrm{Mn}_{0.9} \mathrm{O}_{3-\delta}$ nanofibers is affected. Where, as the rise in $\mathrm{Sr}^{2+}$ content, their coarseness and diameters suffer from reduction. But in contrast, with enhancing the $\mathrm{Sr}^{2+}$ content, the area of surface for the studied sample and also, their grain size significantly increased. Moreover, both bond angles and length between manganese and oxygen ions are significant parameters that possess an outstanding effect in the double exchange of electrons and enhancing the electric conduction leading the improving electrochemical display of perovskites. The electrochemical activities of $\mathrm{La}_{x} \mathrm{Sr}_{1-x} \mathrm{Co}_{0.1} \mathrm{Mn}_{0.9} \mathrm{O}_{3-\delta}$ nanofibers are significantly enhanced when the length is considerably reduced, and the angle is about $180^{\circ}$. The influence of cations substituting on A-site was further investigated by Wang et al. (2020a). The electrospinning and calcination techniques were used to fabricate porosity nanofibers of gadolinium Gd-substituted $\mathrm{SrNiO}_{3}$ (Fig. 10). Some diffraction peaks of gadolinium substituted $\mathrm{SrNiO}_{3}$ (at $x=0.5$, and 0.7 ) are insignificantly increased and passivate owing to the lattice structure deformation from Sr-substituting. The octahedron of $\mathrm{NiO}_{6}$ and the bond angle between $\mathrm{Ni}$ and oxygen are deformed via the occupancy ratio in tetrahedral site elements, which are generated through the various radii between $\mathrm{Gd}^{3+}$ and $\mathrm{Sr}^{2+}$ ions.
Jahn-Teller effect appears as a result of the dissimilar balance in A-site cations, causing stretching and distorting for the standard cubic crystal system on the c-axis, furthermore, lead to weaken the crystallinity of the crystal lattice. Hence, Gadolinium(III) ions with a shorter ion radius than Lanthanum are occupied as A-site ions, and then Strontium(II) ions with a larger ion radius are preferred to locate in the tetrahedral site.

The synthesized $\mathrm{Gd}_{x} \mathrm{Sr}_{1-x} \mathrm{NiO}_{3}$ perovskite has more $\mathrm{O}_{\text {vacancies }}$ and ion defects. It's meriting remarking that the $\mathrm{O}_{\text {vacancies }}$ of $\mathrm{Gd}_{x} \mathrm{Sr}_{1-x} \mathrm{NiO}_{3}$ is simple to achieve and transferred by weak the bond between cation in octahedral site and oxygen and smaller energy, which can promote the transport of electric charge and perform with an outstanding performance in electrochemical energy storage. The product gadolinium-substituted $\mathrm{SrNiO}_{3}$ at $x=0.7$ owns the outstanding activities when utilized as an electrode for supercapacitors, which is strongly affected by the supreme surface area of approximately $16 \mathrm{~m}^{2} \mathrm{~g}^{-1}$ and rational radius of pores reached $3.7 \mathrm{~nm}$. The gadolinium-substituted $\mathrm{SrNiO}_{3}$ at $x=0.7$ exhibits a significant voltage window and outstanding capacitance, where gadolinium-substituted $\mathrm{SrNiO}_{3}$ at $x=0.7$ possesses specific capacitance of $929 \mathrm{~F} \mathrm{~g}^{-1}$ in 1 Molar of sodium sulfate and $764 \mathrm{~F} \mathrm{~g}^{-1}$ in 1 Molar of potassium hydroxide. Besides, the gadolinium-substituted $\mathrm{SrNiO}_{3}$ at $x=0.7$, the device exhibits an excellent energy density about $54 \mathrm{~W} \mathrm{~h} \mathrm{~kg}-1$ and the power density of $1 \mathrm{~kW} \mathrm{~kg}^{-1}$ at $1 \mathrm{~A} \mathrm{~g}^{-1}$. Furthermore at $20 \mathrm{~A} \mathrm{~g}^{-1}$, the sample shows $20 \mathrm{~kW} \mathrm{~kg}^{-1}$ as a remarkable power density and $19 \mathrm{~W} \mathrm{~h} \mathrm{~kg}^{-1}$ as a unique energy density.

In summary, cations substituting in the tetrahedral site of the perovskite has a prominent role in the extent of control or change grain size then obtaining a huge surface area. Moreover, it will affect on bowing the angle between the metal and $\mathrm{O}^{2-}$, and consequently, the variation in the bond length between the metal and $\mathrm{O}^{2-}$. Hence, this pathway leading the electric conduction and $\mathrm{O}^{2-}$ dispersion rate of perovskites will likewise be improved because of $\mathrm{O}_{\text {vacancy }}$ A suited amount of cations substituting in the tetrahedral site could achieve perovskites with enhancing the perovskites capacity display (Nan et al. 2019).

\section{Influence of cation substitution in the octahedral site of perovskite oxides}

Various research concerning anion-intercalation supercapacitors has considered that the suitable choice of the octahedral site cation intends to enhance the $\mathrm{O}_{\text {vacancy }}$ or decrease the inherent resistivity (Elsiddig et al. 2017; Zhu et al. 2016; Li et al. 2017a). Besides, the electrochemical display is based on the octahedral site elements. Liu et al. (2020) investigated the stability window of $\mathrm{Sr}_{2} \mathrm{CoMoO}_{6-\delta}$ affected by $\mathrm{B}$-site cations substituting. The successful 
(a)

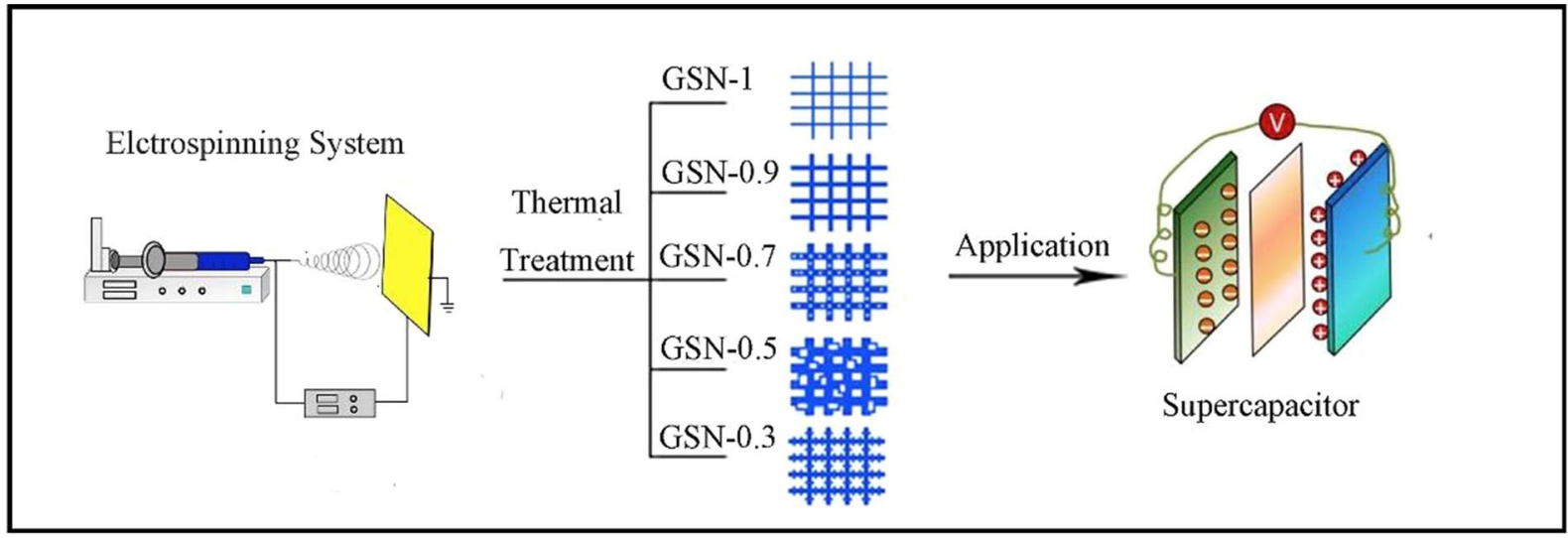

(b)
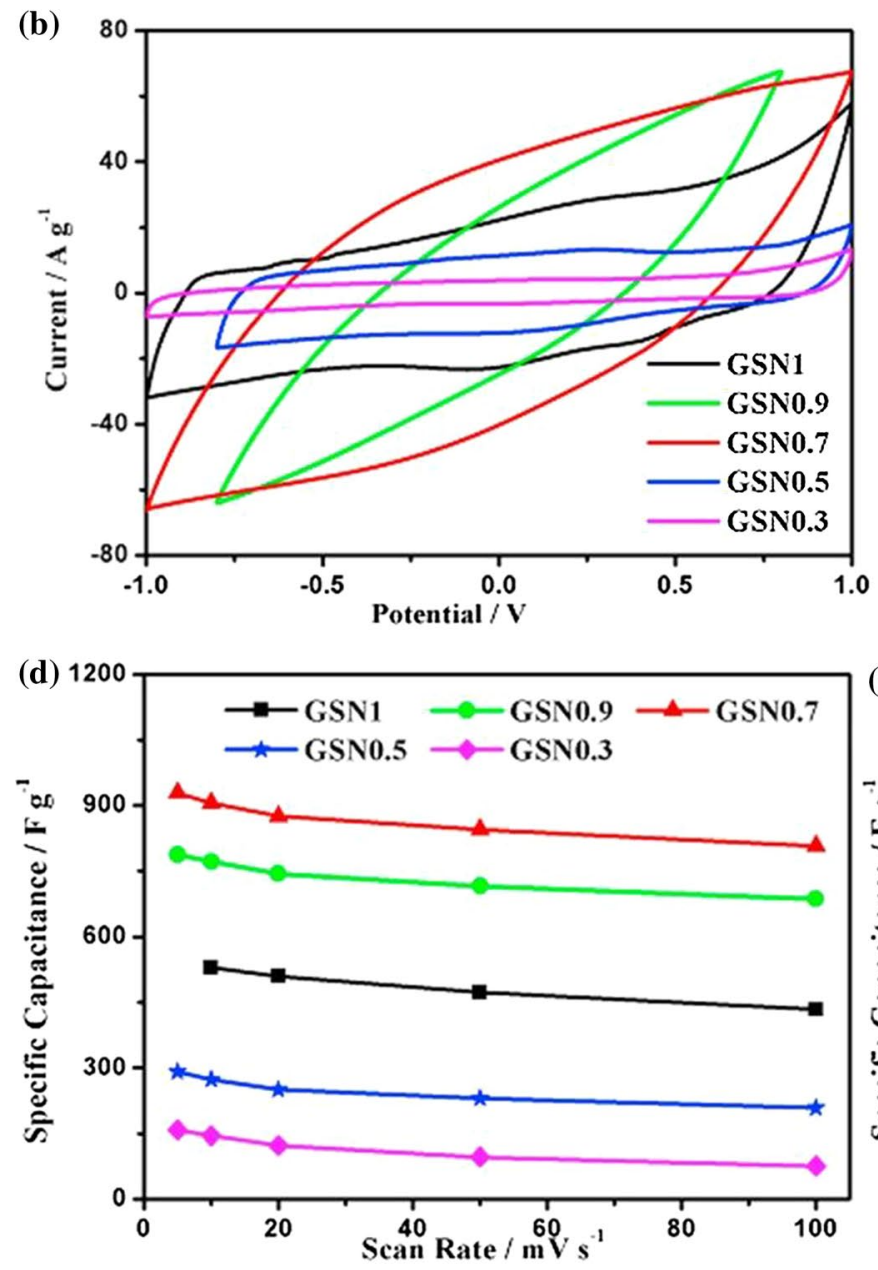

Fig. 10 a The preparation schematic for nanofibers of $\mathrm{Gd}_{\mathrm{x}} \mathrm{Sr}_{1-\mathrm{x}} \mathrm{NiO}_{3}$, b GSN CV curves, $\mathbf{c}$ GSN GCD curves, $\mathbf{d}$ capacitance of GSN Vs. scan rate, e capacitance of GSN Vs. the current density, where GSN

substituting of $\mathrm{Ni}^{2+}$ into the $\mathrm{Sr}_{2} \mathrm{CoMoO}_{6-\delta}$ lattice with various content, i.e., $\mathrm{Sr}_{2} \mathrm{CoMo}_{1-x / 100} \mathrm{Ni}_{x / 100} \mathrm{O}_{6-\delta}$ was affirmed via XRD. A small increment in lattice constants was seen with substituting the Ni atom at the expense of the molybdenum ratio. This is explained by viewing the ionic radius
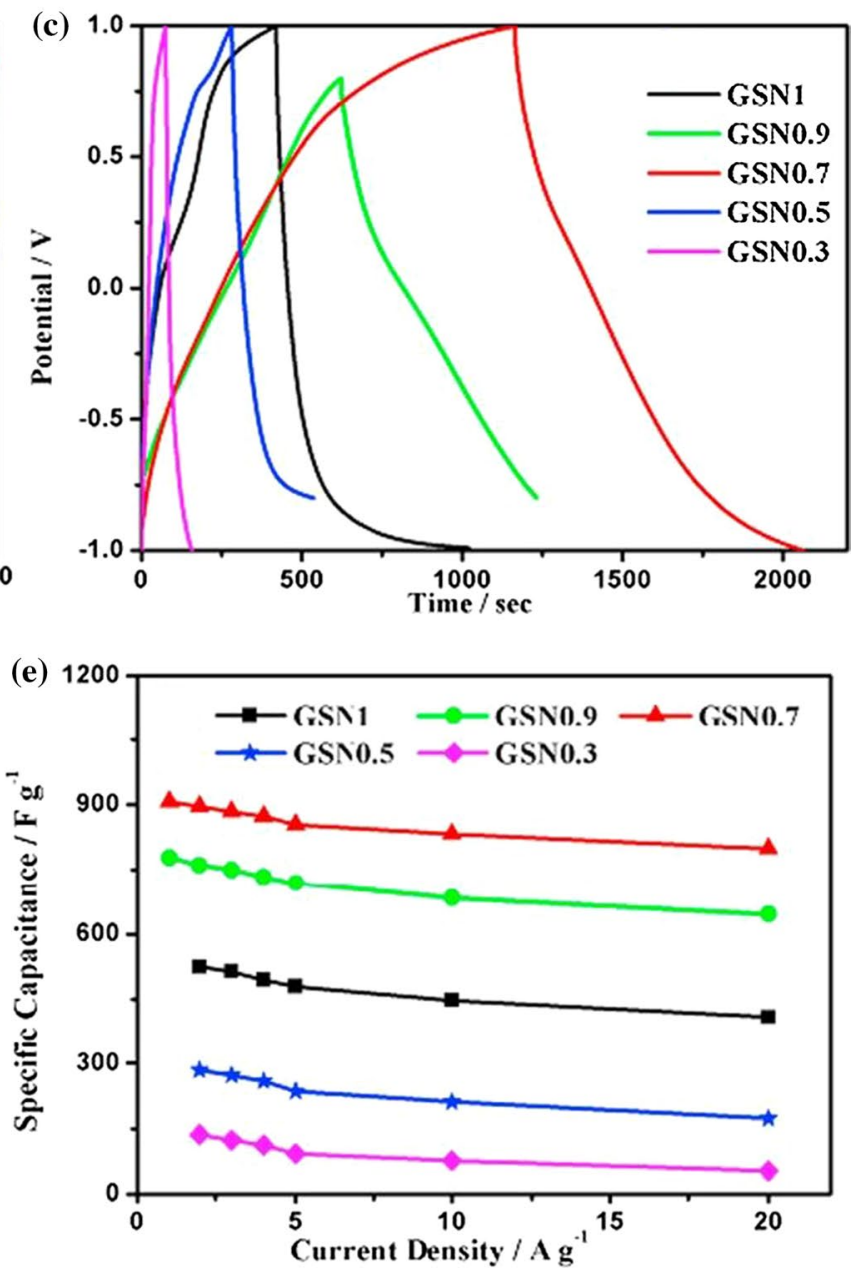

is refer to $\mathrm{Gd}_{\mathrm{x}} \mathrm{Sr}_{1-\mathrm{x}} \mathrm{NiO}_{3}$. Adapted with permission from Wang et al. (2020a). Copyright 2020, Elsevier

of $\mathrm{Ni}^{2+}(0.69 \AA)$, which is larger than the ionic radius of $\mathrm{Mo}^{6+}(0.59 \AA)$ through the octahedral site. The cyclic voltammetry curves of the $\mathrm{Ni}^{2+}$ substituted the $\mathrm{Sr}_{2} \mathrm{CoMoO}_{6}$ electrode confirm that the predominant mechanism for store the carriers is intercalation pseudocapacitive. Nickel 
substituted the $\mathrm{Sr}_{2} \mathrm{CoMoO}_{6}$ samples showed $\mathrm{NiO}$ and $\mathrm{Co}_{3} \mathrm{O}_{4}$ NPs and perovskite oxide phases which provide the entire capacity. The resulting the $\mathrm{O}_{\text {vacancy }}$ energy of the studied perovskite due to nickel and cobalt cations incorporation was also explained by density-functional theory estimation. The generation of oxygen vacancies was promoted once the B-site cations were accelerated from the oxide lattice within the perovskite. With increasing the scan rates, the oxidation peaks moved positively, while reduction peaks moved on the opposite way, implying fast redox reactions and excellent reversibility occurring in the electrodes. Tomar et al. (2018) have enhanced the oxygen vacancies strontium cobaltite $\mathrm{SrCoO}_{3}$ via Mo-doping i.e. $\mathrm{SrCo}_{0.9} \mathrm{Mo}_{0.1} \mathrm{O}_{3-\delta}$. The sol-gel method was utilized to synthesize $\mathrm{SrCoO}_{3}$ and $\mathrm{SrCo}_{0.9} \mathrm{Mo}_{0.1} \mathrm{O}_{3-\delta}$ as an oxygen anion-intercalated chargestorage substances. An extremely high value of diffusion coefficient is characteristic of the efficient accessibility of $\mathrm{OH}^{-}$ions inside the $\mathrm{SrCo}_{0.9} \mathrm{Mo}_{0.1} \mathrm{O}_{3-\delta}$ electrode. At $1 \mathrm{~A} \mathrm{~g}^{-1}$, the specific capacitance of $\mathrm{SrCo}_{0.9} \mathrm{Mo}_{0.1} \mathrm{O}_{3-\delta}$ is around $1220.0 \mathrm{~F} \mathrm{~g}^{-1}$. $\mathrm{SrCo}_{0.9} \mathrm{Mo}_{0.1} \mathrm{O}_{3-\delta}$ exhibits extremely excellent capacitance retention at high current density. Also at $10 \mathrm{~A} \mathrm{~g}^{-1}$, the $\mathrm{SrCo}_{0.9} \mathrm{Mo}_{0.1} \mathrm{O}_{3-\delta}$ electrode exhibited excellent cycling stability and columbic efficiency $(6.48 \%$ only loss from its original capacitance over five thousand cycles). Furthermore, $\mathrm{SrCo}_{0.9} \mathrm{Mo}_{0.1} \mathrm{O}_{3-\delta}$ exhibits better performance than $\mathrm{SrCoO}_{3}$, which is ascribed to higher oxygen vacancies and structural stability. From the above outcomes, we deduce that the substituting of cations inside the B-site enhances the $\mathrm{O}_{\text {vacancies }}$ and improves the capacitance.

In the conclusion of the above review, the potential window of perovskite can be controlled via the cations substituting over the octahedral site. Moreover, as substituent cations possess large orbital valence electrons, the $\mathrm{O}_{\text {vacancies }}$ grew, and then the specific capacity or specific capacitance multiplied (Nan et al. 2019). Furthermore, Table 1 reviews the electrochemical characteristics of some of the latest reported supercapacitors based on the magmatic oxides and their composites.

\section{Transition metals sulfide based on nanocomposite electrode for supercapacitor applications}

Transition metal sulfides, like MoS, CoS, NiS, MnS, FeS etc., represent potential materials for energy storage applications owing to the excellent electrochemical characteristics they exhibit (Zhang et al. 2020b). The electrochemical characteristic of transition metal sulfides is much better than the electrochemical properties of transmission metal oxides. This can be explained by the presence of sulfur atoms instead of oxygen atoms. Hence, the lower electronegativity of sulfur than that of oxygen facilitates electron transfer in the metal sulfide structure easier than that in the metal oxide form. Thus, replacing oxygen with sulfur provides more flexibility for nanomaterials synthesis and fabrication (Jiang et al. 2016).

Transition metal sulfides have attracted interest in many fields of research including, supercapacitors, solar cells and lithium-ion batteries because of their distinctive optical and electrical characteristics, especially when mixed with other materials to prepare nanocomposite structures (Rao 2020).

The main advantages of using nanostructured transition metal sulfides as improved materials that can be utilized as an electrode in electrochemical supercapacitors are because of their excellent electrochemical behavior. Such properties are distinctive structures of their crystal lattice, ultra-high specific capacitance, excellent conductivity of electric current, great redox activity, and small value of their electronegativity (Geng et al. 2018; Yu and David Lou 2018). These superior electrical characteristics of transition metal sulfides are mainly related to their specific forms and structures with extraordinary morphology of their surfaces, in terms of having unique shapes (nano-flowers, nano-rods, kelp-like, nanowires, flaky, hierarchical, the nano-honeycomb-like, etc.) ( $\mathrm{Li}$ et al. 2020).

\section{Nickel sulfide}

Nickel sulfide (NiS) is a semiconductor and can be present in many various compositions. It can also be incorporated in a lot of interesting applications including supercapacitors, dye-sensitized solar cells and quantum-dots. Many electrode materials based on NiS have been studied to investigate their capability of being used as a supercapacitor. NiS nanocomposites have exceptional physicochemical properties with excellent transportation of ions over the electrode surface (Rao 2020). Besides, NiS nanocomposites possess high electrochemical functioning and performance for them to be widely applied as catalysts, as pseudo-capacitors and in dye-sensitized solar cells (Kim et al. 2016). Despite all of these interesting properties and characteristics of NiS nanocomposites, they still have some drawbacks such as limited stability of their questionable lifecycle (Ikkurthi et al. 2018).

For example, Xu et al. (2017) synthesized a nanocomposite electrode based on $\mathrm{NiS}$ and $\mathrm{NiCo}_{2} \mathrm{~S}_{4}$ hydrothermally, the synthesis process is presented as a schematic diagram in Fig. 11. They used activated carbon as a negative electrode and $\mathrm{NiCo}_{2} \mathrm{~S}_{4} / \mathrm{NiS}$ as a positive one. They used a supercapacitor of nickel cobaltite sulfide/nickel sulfide, which had a large active surface area with enhanced electrochemical characteristics such as, at $160 \mathrm{~W} \mathrm{~kg}^{-1}$ of power density, it exhibits an energy density value of $43.7 \mathrm{~W} \mathrm{~h} \mathrm{~kg}^{-1}$ and at 
Table 1 Electrochemical performance of magnetic oxides and their composites

\begin{tabular}{|c|c|c|c|c|c|c|}
\hline No. & Materials & Electrolyte & Specific capacitance & $\begin{array}{l}\text { Energy density and } \\
\text { power density }\end{array}$ & Cyclic stability & References \\
\hline 1 & $\mathrm{MnFe}_{2} \mathrm{O}_{4}$ & $2 \mathrm{M} \mathrm{KOH}$ & $282.4 \mathrm{~F} \mathrm{~g}^{-1}$ & No data & $\begin{array}{l}85.8 \% \text { retention after } \\
2000 \text { cycles }\end{array}$ & Kwon et al. (2017) \\
\hline 2 & $\mathrm{MnFe}_{2} \mathrm{O}_{4}$ & $2 \mathrm{M} \mathrm{KOH}$ & $25.21 \mathrm{~F} \mathrm{~g}^{-1}$ & $\begin{array}{l}12.60 \mathrm{~W} \mathrm{~h} \mathrm{~kg}^{-1} \\
0.74 \mathrm{~W} \mathrm{~kg}^{-1}\end{array}$ & No data & $\begin{array}{l}\text { Singh and Chandra } \\
\text { (2018) }\end{array}$ \\
\hline 3 & $\mathrm{MnFe}_{2} \mathrm{O}_{4}$ & $2 \mathrm{M} \mathrm{KOH}$ & $88.4 \mathrm{~F} \mathrm{~g}^{-1}$ & No data & $\begin{array}{l}69.2 \% \text { retention after } \\
2000 \text { cycles }\end{array}$ & Guo et al. (2017) \\
\hline 4 & $\mathrm{MnFe}_{2} \mathrm{O}_{4} / \mathrm{rGO}$ & $6 \mathrm{M} \mathrm{KOH}$ & $271 \mathrm{~F} \mathrm{~g}^{-1}$ & $\begin{array}{l}15.9 \mathrm{~W} \mathrm{~h} \mathrm{~kg}^{-1} \\
324.5 \mathrm{~W} \mathrm{~kg}^{-1}\end{array}$ & $\begin{array}{l}104 \% \text { retention after } \\
5000 \text { cycles }\end{array}$ & Tabrizi et al. (2017) \\
\hline 5 & $\begin{array}{c}\mathrm{MnFe}_{2} \mathrm{O}_{4} / \text { carbon } \\
\text { black/PANI }\end{array}$ & $0.5 \mathrm{M} \mathrm{H}_{2} \mathrm{SO}_{4}$ & $206 \mathrm{~F} \mathrm{~g}^{-1}$ & $16 \mathrm{~W} \mathrm{~h} \mathrm{~kg}^{-1}$ & $\begin{array}{l}75 \% \text { retention after } \\
100,000 \text { cycle }\end{array}$ & Zha et al. (2015) \\
\hline 6 & $\begin{array}{l}\text { Polyaniline/acetylene } \\
\text { black/CuFe }{ }_{2} \mathrm{O}_{4}\end{array}$ & $1 \mathrm{M} \mathrm{KOH}$ & $732.35 \mathrm{~F} \mathrm{~g}^{-1} \mathrm{Fg}^{-1}$ & $\begin{array}{l}26.757 \mathrm{~W} \mathrm{~h} \mathrm{~kg}^{-1} \\
3165.25 \mathrm{~W} \mathrm{~kg}^{-1}\end{array}$ & $\begin{array}{l}78 \% \text { retention after } \\
5000 \text { cycles }\end{array}$ & Das and Verma (2019) \\
\hline 7 & $\mathrm{Ni}_{1-x} \mathrm{Mg}_{x} \mathrm{Fe}_{2} \mathrm{O}_{4}$ & $6 \mathrm{KOH}$ & $259.89 \mathrm{~F} \mathrm{~g}^{-1}$ & $\begin{array}{l}11.96 \mathrm{~W} \mathrm{~h} \mathrm{~kg}^{-1} \\
143.9 \mathrm{~kW} \mathrm{~kg}^{-1}\end{array}$ & $\begin{array}{l}88.79 \% \text { retention after } \\
1000 \text { cycles }\end{array}$ & $\begin{array}{l}\text { Wongpratat et al. } \\
\text { (2020) }\end{array}$ \\
\hline 8 & $\mathrm{NiAl}_{0.1} \mathrm{Fe}_{1.9} \mathrm{O}_{4}$ & $2 \mathrm{M} \mathrm{KOH}$ & $250.9 \mathrm{~F} \mathrm{~g}^{-1}$ & No data & $\begin{array}{l}98.7 \% \text { retention after } \\
1000 \text { cycles }\end{array}$ & Ramadevi et al. (2020) \\
\hline 9 & $\mathrm{Co}_{0.5} \mathrm{Ni}_{0.5} \mathrm{Fe}_{2} \mathrm{O}_{4}$ & $3 \mathrm{M} \mathrm{KOH}$ & $630.00 \mathrm{~F} \mathrm{~g}^{-1}$ & $\begin{array}{l}7.43 \mathrm{~W} \mathrm{~h} \mathrm{~kg}^{-1} \\
60.45 \mathrm{~W} \mathrm{~kg}^{-1}\end{array}$ & $\begin{array}{l}82 \% \text { retention after } \\
1500 \text { cycles }\end{array}$ & Sharifi et al. (2020) \\
\hline 10 & $\begin{array}{l}\mathrm{MnFe}_{2} \mathrm{O}_{4}-\mathrm{ZnFe}_{2} \mathrm{O}_{4} / \\
\text { graphene }\end{array}$ & $\mathrm{KOH}$ & $263 \mathrm{~mA} \mathrm{~h} \mathrm{~g}^{-1}$ & $\begin{array}{l}75.65 \mathrm{~W} \mathrm{~h} \mathrm{~kg}^{-1} \\
6629.53 \mathrm{~W} \mathrm{~kg}^{-1}\end{array}$ & $\begin{array}{l}96.89 \% \text { retention after } \\
5000 \text { cycles }\end{array}$ & Gopi et al. (2020) \\
\hline 11 & $\mathrm{CoFe}_{2} \mathrm{O}_{4} / \mathrm{MWCNTs}$ & $2 \mathrm{M} \mathrm{KOH}$ & $390 \mathrm{~F} \mathrm{~g}^{-1}$ & $\begin{array}{l}26.7 \mathrm{~W} \mathrm{~h} \mathrm{~kg}^{-1} \\
319 \mathrm{~W} \mathrm{~kg}^{-1}\end{array}$ & $\begin{array}{l}\text { 93\% retention after } \\
2000 \text { cycles }\end{array}$ & Acharya et al. (2020) \\
\hline 12 & $\mathrm{Mg}_{1-x} \mathrm{Zn}_{x} \mathrm{Fe}_{2} \mathrm{O}_{4}$ & $1 \mathrm{~mol} \mathrm{~L}^{-1} \mathrm{Na}_{2} \mathrm{SO}_{4}$ & $484.6 \mathrm{~F} \mathrm{~g}^{-1}$ & $\begin{array}{l}10.8 \mathrm{~W} \mathrm{~h} \mathrm{~kg}^{-1} \\
0.5 \mathrm{~kW} \mathrm{~kg}^{-1}\end{array}$ & - & Uke et al. (2020) \\
\hline 13 & rGO- $\mathrm{NiFe}_{2} \mathrm{O}_{4}$ & $1 \mathrm{M} \mathrm{Na}_{2} \mathrm{SO}_{4}$ & $210.9 \mathrm{~F} \mathrm{~g}^{-1}$ & $\begin{array}{l}23.7 \mathrm{~W} \mathrm{~h} \mathrm{~kg}^{-1} \\
225 \mathrm{~W} \mathrm{~kg}^{-1}\end{array}$ & $\begin{array}{l}94.2 \% \text { retention after } \\
5000 \text { cycles }\end{array}$ & Cai et al. (2019) \\
\hline 14 & $\mathrm{CoMnFeO}_{4}$ & $3 \mathrm{M} \mathrm{KOH}$ & $770 \mathrm{~F} \mathrm{~g}^{-1}$ & - & $\begin{array}{l}88 \% \text { retention after } \\
8000 \text { cycles }\end{array}$ & $\begin{array}{l}\text { Saleh Ghadimi et al. } \\
\text { (2019) }\end{array}$ \\
\hline 15 & $\mathrm{ZnFe}_{2} \mathrm{O}_{4}$ & $2 \mathrm{M} \mathrm{NaOH}$ & $1235 \mathrm{~F} \mathrm{~g}^{-1}$ & $\begin{array}{l}33 \mathrm{~W} \mathrm{~h} \mathrm{~kg}^{-1} \\
68 \mathrm{~W} \mathrm{~kg}^{-1}\end{array}$ & - & $\begin{array}{l}\text { Shanmugavani and } \\
\text { Selvan (2014) }\end{array}$ \\
\hline 16 & $\mathrm{CuFe}_{2} \mathrm{O}_{4} / \mathrm{RGO}$ & $3 \mathrm{M} \mathrm{KOH}$ & $797 \mathrm{~F} \mathrm{~g}^{-1}$ & $\begin{array}{l}11 \mathrm{~W} \mathrm{~h} \mathrm{~kg}^{-1} \\
543 \mathrm{~W} \mathrm{~kg}^{-1}\end{array}$ & $\begin{array}{l}92 \% \text { retention after } \\
2000 \text { cycles }\end{array}$ & Chandel et al. (2018) \\
\hline 17 & $\mathrm{ZnFe}_{2} \mathrm{O}_{4}$ & $6 \mathrm{M} \mathrm{KOH}$ & $118 \mathrm{~F} \mathrm{~g}^{-1}$ & $\begin{array}{l}42 \mathrm{~W} \mathrm{~h} \mathrm{~kg}^{-1} \\
5 \mathrm{~kW} \mathrm{~kg}^{-1}\end{array}$ & $\begin{array}{l}83 \% \text { retention after } \\
8000 \text { cycles }\end{array}$ & Vadiyar et al. (2016b) \\
\hline 18 & $\begin{array}{l}\mathrm{CoFe}_{2} \mathrm{O}_{4} / \text { graphene/ } \\
\text { PANI }\end{array}$ & $6 \mathrm{M} \mathrm{KOH}$ & $1123 \mathrm{~F} \mathrm{~g}^{-1} \mathrm{~F} \mathrm{~g}^{-1}$ & $\begin{array}{l}240 \mathrm{~W} \mathrm{~h} \mathrm{~kg}^{-1} \\
2680 \mathrm{~W} \mathrm{~kg}^{-1}\end{array}$ & $\begin{array}{l}98.2 \% \text { retention after } \\
2000 \text { cycles }\end{array}$ & Mousa et al. (2017) \\
\hline 19 & $\mathrm{PANI} / \mathrm{MnFe}_{2} \mathrm{O}_{4}$ & $1 \mathrm{M} \mathrm{H}_{2} \mathrm{SO}_{4}$ & $371 \mathrm{~F} \mathrm{~g}^{-1}$ & - & $\begin{array}{l}86.7 \% \text { retention after } \\
1000\end{array}$ & Arsalani et al. (2018) \\
\hline 20 & $\begin{array}{l}\text { Carbon fiber cloth/ } \\
\mathrm{CoFe}_{2} \mathrm{O}_{4}\end{array}$ & $3 \mathrm{M} \mathrm{KOH}$ & $237.8 \mathrm{~F} \mathrm{~g}^{-1}$ & $\begin{array}{l}84.6 \mathrm{~W} \mathrm{~h} \mathrm{~kg}^{-1} \\
1334 \mathrm{~W} \mathrm{~kg}^{-1}\end{array}$ & - & Song et al. (2019) \\
\hline 21 & $\mathrm{ZnMoO}_{4}$ & $3 \mathrm{M} \mathrm{KOH}$ & $704.8 \mathrm{~F} \mathrm{~g}^{-1}$ & $\begin{array}{l}22.45 \mathrm{~W} \mathrm{~h} \mathrm{~kg}^{-1} \\
800.06 \mathrm{~kW} \mathrm{~kg}^{-1}\end{array}$ & $\begin{array}{l}93.6 \% \text { retention after } \\
10,000 \text { cycles }\end{array}$ & Gao et al. (2018a) \\
\hline 22 & $\mathrm{Ag} / \mathrm{NiMoO}_{4}$ & $3 \mathrm{M} \mathrm{KOH}$ & $3342.7 \mathrm{~F} \mathrm{~g}^{-1}$ & $\begin{array}{l}48.5 \mathrm{~W} \mathrm{~h} \mathrm{~kg}^{-1} \\
212.5 \mathrm{kWh} \mathrm{kg}^{-1}\end{array}$ & $\begin{array}{l}84.4 \% \text { retention after } \\
5000 \text { cycles }\end{array}$ & Zhang et al. (2020a) \\
\hline 23 & $\begin{array}{l}\text { Zn-Ni-Co oxide@ } \\
\text { NiMoO }_{4}\end{array}$ & $\mathrm{KOH} / \mathrm{PVA}$ & $87.5 \mathrm{~mA} \mathrm{~h} \mathrm{~g}^{-1}$ & $\begin{array}{l}70 \mathrm{~W} \mathrm{~h} \mathrm{~kg}^{-1} \\
5115.1 \mathrm{~W} \mathrm{~kg}^{-1}\end{array}$ & $\begin{array}{l}91 \% \text { retention after } \\
10,000\end{array}$ & $\begin{array}{l}\text { Bandyopadhyay et al. } \\
\text { (2020) }\end{array}$ \\
\hline 24 & $\mathrm{MnMoO}_{4} / \mathrm{CoMoO}_{4}$ & $2 \mathrm{M} \mathrm{NaOH}$ & $204.1 \mathrm{Fg}^{-1}$ & $28.4 \mathrm{~W} \mathrm{~h} \mathrm{~kg}^{-1}$ & $\begin{array}{l}98 \% \text { retention after } \\
1000 \text { cycles }\end{array}$ & Mai et al. (2011b) \\
\hline 25 & $\mathrm{NiMoO}_{4} / \mathrm{MoO}_{3}$ & $3 \mathrm{M} \mathrm{KOH}$ & $184 \mathrm{~F} \mathrm{~g}^{-1}$ & $37.5 \mathrm{~W} \mathrm{~h} \mathrm{~kg}^{-1}$ & $\begin{array}{l}100 \% \text { retention after } \\
75,000 \text { cycles }\end{array}$ & Zhang et al. (2018b) \\
\hline 26 & $\mathrm{MoS}_{2} / \mathrm{NiCo}_{2} \mathrm{O}_{4}$ & $3 \mathrm{M} \mathrm{KOH}$ & $51.7 \mathrm{~F} \mathrm{~g}^{-1}$ & $\begin{array}{l}18.4 \mathrm{~W} \mathrm{~h} \mathrm{~kg}^{-1} \\
1200.2 \mathrm{~W} \mathrm{~kg}^{-1}\end{array}$ & $\begin{array}{l}98.2 \% \text { retention after } \\
8000 \text { cycles }\end{array}$ & Wen et al. (2018) \\
\hline 27 & $\begin{array}{l}\mathrm{ZnCo}_{2} \mathrm{O}_{4} @ \\
\quad \mathrm{NiMoO}_{4} \cdot \mathrm{H}_{2} \mathrm{O}\end{array}$ & $1 \mathrm{M} \mathrm{KOH}$ & $3.53 \mathrm{~F} \mathrm{~cm}^{-2}$ & $\begin{array}{l}2.55 \mathrm{mWh} \mathrm{cm}^{-3} \\
0.033 \mathrm{~W} \mathrm{~cm}^{-3}\end{array}$ & $\begin{array}{l}88 \% \text { retention after } \\
5000 \text { cycles }\end{array}$ & Chen et al. (2019a) \\
\hline
\end{tabular}


Table 1 (continued)

\begin{tabular}{|c|c|c|c|c|c|c|}
\hline No. & Materials & Electrolyte & Specific capacitance & $\begin{array}{l}\text { Energy density and } \\
\text { power density }\end{array}$ & Cyclic stability & References \\
\hline 28 & $\mathrm{CoMoO}_{4}-\mathrm{NiMoO}_{4}$ & $2 \mathrm{M} \mathrm{KOH}$ & $1079 \mathrm{~F} \mathrm{~g}^{-1}$ & $\begin{array}{l}33 \mathrm{~W} \mathrm{~h} \mathrm{~kg}^{-1} \\
375 \mathrm{~W} \mathrm{~kg}^{-1}\end{array}$ & $\begin{array}{l}98.4 \% \text { retention after } \\
1000 \text { cycles }\end{array}$ & Yin et al. (2015b) \\
\hline 29 & $\mathrm{NiMoO}_{4} @ \mathrm{CoMoO}_{4}$ & $1 \mathrm{M} \mathrm{KOH}$ & $1601 \mathrm{Fg}^{-1}$ & - & $\begin{array}{l}83 \% \text { retention after } \\
2000 \text { cycles }\end{array}$ & Zhang et al. (2015b) \\
\hline 30 & $\mathrm{CoMoO}_{4} / \mathrm{Co}_{3} \mathrm{O}_{4}$ & $3 \mathrm{M} \mathrm{KOH}$ & $1062.5 \mathrm{~F} \mathrm{~g}^{-1}$ & $\begin{array}{l}31.64 \mathrm{~W} \mathrm{~h} \mathrm{~kg}^{-1} \\
7270 \mathrm{~W} \mathrm{~kg}^{-1}\end{array}$ & $\begin{array}{l}90.38 \% \text { retention after } \\
2000 \text { cycles }\end{array}$ & Zhou et al. (2015) \\
\hline 31 & $\mathrm{NiMoO}_{4} @ \mathrm{NiWO}_{4}$ & $3 \mathrm{M} \mathrm{KOH}$ & $1290 \mathrm{~F} \mathrm{~g}^{-1}$ & - & $\begin{array}{l}93.1 \% \text { retention after } \\
3000 \text { cycles }\end{array}$ & Reddy et al. (2018b) \\
\hline 32 & $\alpha-\mathrm{ZnMoO}_{4}$ & $2 \mathrm{M} \mathrm{KOH}$ & $234.75 \mathrm{~F} \mathrm{~g} \mathrm{~g}^{-1}$ & $\begin{array}{l}20.808 \mathrm{~W} \mathrm{~h} \mathrm{~kg}^{-1} \\
199.44 \mathrm{~W} \mathrm{~kg}^{-1}\end{array}$ & $\begin{array}{l}82 \% \text { retention after } \\
1600 \text { cycles }\end{array}$ & Reddy et al. (2019) \\
\hline 33 & $\begin{array}{l}\mathrm{NiMoO}_{4} / \text { graphene } \\
\text { nanosheets }\end{array}$ & $2 \mathrm{M} \mathrm{LiOH}$ & $3868 \mathrm{~F} \mathrm{~g}^{-1}$ & $\begin{array}{l}54 \mathrm{~W} \mathrm{~h} \mathrm{~kg}^{-1} \\
19478 \mathrm{~W} \mathrm{~kg}^{-1}\end{array}$ & $\begin{array}{l}98 \% \text { retention after } \\
4000 \text { cycles }\end{array}$ & Kazemi et al. (2016) \\
\hline 34 & $\begin{array}{c}\mathrm{Mn}_{0.33} \mathrm{Nio}_{0.33} \mathrm{Co} \\
0.33 \mathrm{MoO}_{4}\end{array}$ & $2 \mathrm{M} \mathrm{NaOH}$ & $124 \mathrm{~F} \mathrm{~g}^{-1}$ & $\begin{array}{l}82 \mathrm{~W} \mathrm{~h} \mathrm{~kg}^{-1} \\
1650 \mathrm{~W} \mathrm{~kg}^{-1}\end{array}$ & $\begin{array}{l}80 \% \text { retention after } \\
2000 \text { cycles }\end{array}$ & Minakshi et al. (2017) \\
\hline 35 & $\mathrm{MnCo}_{2} \mathrm{O}_{4} @ \mathrm{NiMoO}_{4}$ & $2 \mathrm{M} \mathrm{KOH}$ & $1244 \mathrm{~F} \mathrm{~g}^{-1}$ & $\begin{array}{l}42 \mathrm{~W} \mathrm{~h} \mathrm{~kg}^{-1} \\
852.3 \mathrm{~W} \mathrm{~kg}^{-1}\end{array}$ & $\begin{array}{l}93 \% \text { retention after } \\
8000 \text { cycles }\end{array}$ & Mehrez et al. (2019) \\
\hline 36 & $\mathrm{FeCO}_{2} \mathrm{O}_{4}$ & $3 \mathrm{M} \mathrm{KOH}$ & $960.0 \mathrm{~F} \mathrm{~g}^{-1}$ & $\begin{array}{l}34.5 \mathrm{~W} \mathrm{~h} \mathrm{~kg}^{-1} \\
6391.7 \mathrm{~W} \mathrm{~kg}^{-1}\end{array}$ & $\begin{array}{l}94 \% \text { retention after } \\
10,000 \text { cycles }\end{array}$ & Lalwani et al. (2019) \\
\hline 37 & $\mathrm{NiCo}_{2} \mathrm{O}_{4}$-graphene & $2 \mathrm{M} \mathrm{KOH}$ & $845 \mathrm{~F} \mathrm{~g}^{-1} \mathrm{Fg}^{-1}$ & $\begin{array}{l}52.2 \mathrm{~W} \mathrm{~h} \mathrm{~kg}^{-1} \\
187 \mathrm{~W} \mathrm{~kg}^{-1}\end{array}$ & $\begin{array}{l}97.3 \% \text { retention after } \\
10,000 \text { cycles }\end{array}$ & Lv et al. (2017) \\
\hline 38 & $\mathrm{ZnCo}_{2} \mathrm{O}_{4}$ & $2 \mathrm{M} \mathrm{KOH}$ & $812 \mathrm{~F} \mathrm{~g}^{-1}$ & - & $\begin{array}{l}88 \% \text { retention after } \\
5100 \text { cycles }\end{array}$ & $\begin{array}{l}\text { Ramachandran and } \\
\text { Hamed (2018) }\end{array}$ \\
\hline 39 & Polyaniline- $-\mathrm{CuCo}_{2} \mathrm{O}_{4}$ & $1 \mathrm{M} \mathrm{KOH}$ & $403 \mathrm{C} \mathrm{g}^{-1}$ & $\begin{array}{l}76 \mathrm{~W} \mathrm{~h} \mathrm{~kg}^{-1} \\
599 \mathrm{~W} \mathrm{~kg}^{-1}\end{array}$ & $\begin{array}{l}94 \% \text { retention after } \\
3000 \text { cycles }\end{array}$ & Omar et al. (2017) \\
\hline 40 & $\begin{array}{l}\text { Carbon black/ } \\
\mathrm{NiCo}_{2} \mathrm{O}_{4}\end{array}$ & $1 \mathrm{M} \mathrm{KOH}$ & $604.4 \mathrm{C} \mathrm{g}^{-1}$ & $\begin{array}{l}33.7 \mathrm{~W} \mathrm{~h} \mathrm{~kg}^{-1} \\
12.2 \mathrm{~kW} \mathrm{~kg}^{-1}\end{array}$ & $\begin{array}{l}\sim 90 \% \text { retention after } \\
50,000\end{array}$ & Zha et al. (2017) \\
\hline 41 & $\begin{array}{l}\text { Carbon fiber paper@ } \\
\mathrm{NiCo}_{2} \mathrm{O}_{4} / \text { graphene } \\
\text { foam }\end{array}$ & $2 \mathrm{M} \mathrm{KOH}$ & $254 \mathrm{~F} \mathrm{~g}^{-1}$ & $\begin{array}{l}34.5 \mathrm{~W} \mathrm{~h} \mathrm{~kg}^{-1} \\
547 \mathrm{~W} \mathrm{~kg}^{-1}\end{array}$ & $\begin{array}{l}92.2 \% \text { retention after } \\
10,000 \text { cycles }\end{array}$ & Tang et al. (2015a) \\
\hline 42 & $\begin{array}{c}\mathrm{NiCo}_{2} \mathrm{O}_{4}-\text { reduced } \\
\text { graphene oxide }\end{array}$ & $2 \mathrm{M} \mathrm{KOH}$ & $870 \mathrm{~F} \mathrm{~g}^{-1}$ & - & $\begin{array}{l}90 \% \text { retention after } \\
5000 \text { cycles }\end{array}$ & $\begin{array}{l}\text { Umeshbabu et al. } \\
\text { (2015) }\end{array}$ \\
\hline 43 & $\mathrm{NiCo}_{2} \mathrm{O}_{4} @ \mathrm{MnO}_{2}$ & $1 \mathrm{M} \mathrm{NaOH}$ & $112 \mathrm{~F} \mathrm{~g}^{-1}$ & $35 \mathrm{~W} \mathrm{~h} \mathrm{~kg}^{-1}$ & $\begin{array}{l}\sim 113.6 \% \text { retention } \\
\text { after } 8000 \text { cycles }\end{array}$ & Xu et al. (2014) \\
\hline 44 & $\begin{array}{l}\text { Carbon nanotube@ } \\
\mathrm{NiCo}_{2} \mathrm{O}_{4}\end{array}$ & $6 \mathrm{M} \mathrm{KOH}$ & $1038 \mathrm{Fg}^{-1}$ & $\begin{array}{l}19.7 \mathrm{~W} \mathrm{~h} \mathrm{~kg}^{-1} \\
62.5 \mathrm{~W} \mathrm{~kg}^{-1}\end{array}$ & $\begin{array}{l}100 \% \text { retention after } \\
1000 \text { cycles }\end{array}$ & Cai et al. (2014b) \\
\hline 45 & $\mathrm{FeCO}_{2} \mathrm{O}_{4}$ & $3 \mathrm{M} \mathrm{KOH}$ & $407 \mathrm{~F} \mathrm{~g}^{-1} \mathrm{~F} \mathrm{~g}^{-1}$ & $\begin{array}{l}3 \mathrm{~W} \mathrm{~h} \mathrm{~kg}^{-1} \\
3780 \mathrm{~W} \mathrm{~kg}^{-1}\end{array}$ & $\begin{array}{l}142 \% \text { retention after } \\
2000 \text { cycles }\end{array}$ & $\begin{array}{l}\text { Pendashteh et al. } \\
\text { (2015) }\end{array}$ \\
\hline 46 & $\begin{array}{l}\mathrm{NiCo}_{2} \mathrm{O}_{4} @ \text { poly }(3,4- \\
\text { ethylenedioxypyr- } \\
\text { role) }\end{array}$ & $\mathrm{NiCo}_{2} \mathrm{O}_{4}$ & $1775 \mathrm{Fg}^{-1}$ & $\begin{array}{l}898 \mathrm{~W} \mathrm{~h} \mathrm{~kg}^{-1} \\
1.25 \mathrm{~kW} \mathrm{~kg}^{-1}\end{array}$ & $\begin{array}{l}\sim 95 \% \text { retention after } \\
5000 \text { cycles }\end{array}$ & Deshagani et al. (2019) \\
\hline 47 & $\mathrm{MnCo}_{2} \mathrm{O}_{4} @$ graphene & $1 \mathrm{M} \mathrm{KOH}$ & $406.50 \mathrm{~F} \mathrm{~g}^{-1} \mathrm{~F} \mathrm{~g}^{-1}$ & $\begin{array}{l}20.32 \mathrm{~W} \mathrm{~h} \mathrm{~kg}^{-1} \\
300 \mathrm{~kW} \mathrm{~kg}^{-1}\end{array}$ & $\begin{array}{l}95 \% \text { retention after } \\
5000 \text { cycles }\end{array}$ & Saren et al. (2019) \\
\hline 48 & $\mathrm{CoO} / \mathrm{NiCo}_{2} \mathrm{O}_{4}$ & $2 \mathrm{M} \mathrm{KOH}$ & $908 \mathrm{~F} \mathrm{~g}^{-1}$ & - & $\begin{array}{l}75 \% \text { retention after } \\
3000 \text { cycles }\end{array}$ & Jang et al. (2015) \\
\hline 49 & $\mathrm{LaMnO}_{3}$ & $0.5 \mathrm{M} \mathrm{Na}_{2} \mathrm{SO}_{4}$ & $520 \mathrm{~F} \mathrm{~g}^{-1}$ & $\begin{array}{l}52.5 \mathrm{~W} \mathrm{~h} \mathrm{~kg}^{-1} \\
1000 \mathrm{~W} \mathrm{~kg}^{-1}\end{array}$ & $\begin{array}{l}117 \% \text { retention after } \\
7500 \text { cycles }\end{array}$ & Shafi et al. (2018) \\
\hline 50 & $\mathrm{La}_{0.85} \mathrm{Sr}_{0.15} \mathrm{MnO}_{3}$ & $1 \mathrm{M} \mathrm{KOH}$ & $198 \mathrm{~F} \mathrm{~g}^{-1}$ & - & $\begin{array}{l}78 \% \text { retention after } \\
1000 \text { cycles }\end{array}$ & Wang et al. (2016b) \\
\hline 51 & $\begin{array}{l}\left(\mathrm{La}_{0.75} \mathrm{Sr}_{0.25}\right)_{0.95} \mathrm{Mn} \\
\quad \mathrm{O}_{3-\delta}\end{array}$ & $1 \mathrm{M} \mathrm{Na}_{2} \mathrm{SO}_{4}$ & $56 \mathrm{~F} \mathrm{~g}^{-1} \mathrm{Fg}^{-1}$ & - & $\begin{array}{l}98 \% \text { retention after } \\
1000 \text { cycles }\end{array}$ & Lü et al. (2015) \\
\hline 52 & $\mathrm{SrRuO}_{3}$ & $1 \mathrm{M} \mathrm{KOH}$ & $52.4 \mathrm{~F} \mathrm{~g}^{-1}$ & - & $\begin{array}{l}77.8 \% \text { retention after } \\
1000 \text { cycles }\end{array}$ & Galal et al. (2018) \\
\hline 53 & $\mathrm{La}_{\mathrm{x}} \mathrm{Sr}_{1-x} \mathrm{NiO}_{3-\delta}$ & $1 \mathrm{M} \mathrm{Na}_{2} \mathrm{SO}_{4}$ & $719 \mathrm{~F} \mathrm{~g}^{-1}$ & $\begin{array}{l}81.4 \mathrm{~W} \mathrm{~h} \mathrm{~kg}^{-1} \\
500 \mathrm{~W} \mathrm{~kg}^{-1}\end{array}$ & $\begin{array}{l}90 \% \text { retention after } \\
2000 \text { cycles }\end{array}$ & Cao et al. (2015b) \\
\hline
\end{tabular}


Table 1 (continued)

\begin{tabular}{|c|c|c|c|c|c|c|}
\hline No. & Materials & Electrolyte & Specific capacitance & $\begin{array}{l}\text { Energy density and } \\
\text { power density }\end{array}$ & Cyclic stability & References \\
\hline 54 & $\begin{array}{l}\text { Reduced graphene } \\
\text { oxide/LaAlO } \\
3\end{array}$ & $1 \mathrm{M} \mathrm{KOH}$ & $283 \mathrm{Fg}^{-1} \mathrm{Fg}^{-1}$ & $\begin{array}{l}57 \mathrm{~W} \mathrm{~h} \mathrm{~kg}^{-1} \\
569 \mathrm{~W} \mathrm{~kg}^{-1}\end{array}$ & $\begin{array}{l}74 \% \text { retention after } \\
5000 \text { cycles }\end{array}$ & Vinuth Raj et al. (2020) \\
\hline 55 & $\begin{array}{l}\mathrm{La}_{0.8} \mathrm{Nd}_{0.2} \mathrm{Fe}_{0.8} \mathrm{Mn} \\
{ }_{0.2} \mathrm{O}_{3} \text { /nitrogen-doped } \\
\text { graphene oxide }\end{array}$ & $3 \mathrm{M} \mathrm{KOH}$ & $1060 \mathrm{~F} \mathrm{~g}^{-1}$ & - & $\begin{array}{l}92.4 \% \text { retention after } \\
1000 \text { cycles }\end{array}$ & $\begin{array}{l}\text { Rezanezhad et al. } \\
\text { (2020) }\end{array}$ \\
\hline 56 & $\mathrm{SrTiO}_{3}$ & $3 \mathrm{M} \mathrm{KOH}$ & $592 \mathrm{~F} \mathrm{~g}^{-1}$ & $\begin{array}{l}27.8 \mathrm{~W} \mathrm{~h} \mathrm{~kg}^{-1} \\
1921 \mathrm{~W} \mathrm{~kg}^{-1}\end{array}$ & $\begin{array}{l}99 \% \text { retention after } \\
5000 \text { cycles }\end{array}$ & Tomar et al. (2019) \\
\hline 57 & $\mathrm{Ag} @ \mathrm{La}_{2} \mathrm{NiO}_{4+\delta}$ & $1 \mathrm{M} \mathrm{KOH}$ & $466.4 \mathrm{C} \mathrm{g}^{-1}$ & $\begin{array}{l}44.7 \mathrm{~W} \mathrm{~h} \mathrm{~kg}^{-1} \\
800 \mathrm{~W} \mathrm{~kg}^{-1}\end{array}$ & $\begin{array}{l}93 \% \text { retention after } \\
10,000 \text { cycles }\end{array}$ & Wei et al. (2019) \\
\hline 58 & $\mathrm{Ag} @ \mathrm{La}_{0.7} \mathrm{Sr}_{0.3} \mathrm{CoO}_{3-\delta}$ & $1 \mathrm{M} \mathrm{KOH}$ & $517.5 \mathrm{Fg}^{-1}$ & $52.0 \mathrm{~W} \mathrm{~h} \mathrm{~kg}^{-1}$ & $\begin{array}{l}85.6 \% \text { retention after } \\
3000 \text { cycles }\end{array}$ & Liu et al. (2017a) \\
\hline 59 & $\mathrm{LaMnO}_{3} @ \mathrm{NiCo}_{2} \mathrm{O}_{4}$ & $6 \mathrm{M} \mathrm{KOH}$ & $811 \mathrm{C} \mathrm{g}^{-1}$ & $\begin{array}{l}36.6 \mathrm{~W} \mathrm{~h} \mathrm{~kg}^{-1} \\
800 \mathrm{~W} \mathrm{~kg}^{-1}\end{array}$ & $\begin{array}{l}96 \% \text { retention after } \\
2000 \text { cycles }\end{array}$ & Tian et al. (2019) \\
\hline 60 & $\begin{array}{l}\mathrm{BiYO}_{3} / \text { reduced gra- } \\
\text { phene oxide }\end{array}$ & $6 \mathrm{M} \mathrm{KOH}$ & $696 \mathrm{~F} \mathrm{~g}^{-1}$ & & $\begin{array}{l}91 \% \text { retention after } \\
2000 \text { cycles }\end{array}$ & Selvarajan et al. (2020) \\
\hline
\end{tabular}

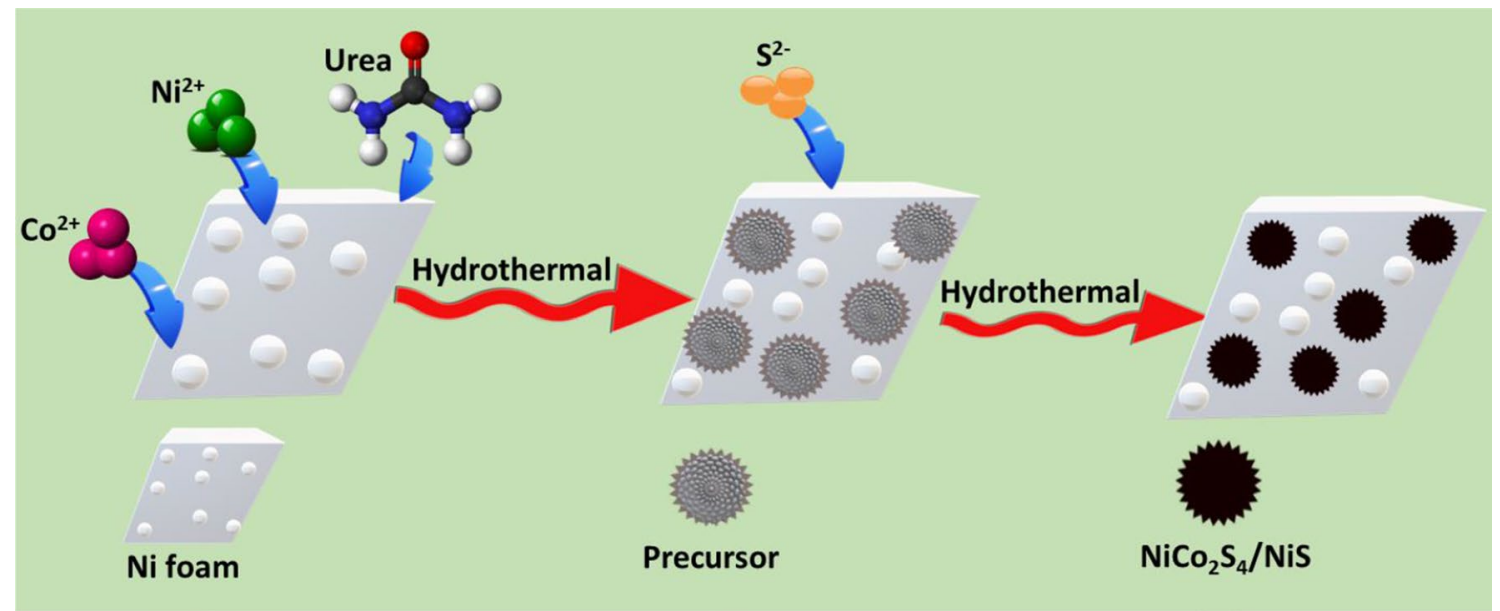

Fig. 11 Hydrothermal synthesis of the nickel cobaltite sulfide/nickel sulfide nanocomposite

a current density of $1 \mathrm{~mA} \mathrm{~cm}{ }^{-2}$ the specific capacitance reached its maximum value of $123 \mathrm{~F} \mathrm{~g}^{-1}$.

\section{Cobalt sulfide}

Cobalt sulfide $\mathrm{CoS}_{2}$ has many advantages in the field of supercapacitors as it is readily available raw materials, easy to synthesize and environment-friendly material, in addition to its high electrical conductance with plenty of sites available for redox reactions to occur ( $\mathrm{Li}$ et al. 2016a). Several nanostructured electrode materials based on $\mathrm{CoS}$ have been prepared for utilization in the area of energy storage and supercapacitors. Recently, Govindasamy et al. (2019b) used the hydrothermal method to spread nanostructured nickel cobaltite sulfide/cobalt sulfide on a piece of carbon cloth in a two-step process as shown in Fig. 12. The prepared nickel cobaltite sulfide/cobalt sulfide exhibits a good specific capacitance of $1565 \mathrm{~F} \mathrm{~g}^{-1}$ at a current density $1 \mathrm{~A} \mathrm{~g}^{-1}$ and retained $91 \%$ of its initial SC after a number of 8000 cycles at a current density $1 \mathrm{~A} \mathrm{~g}^{-1}$. At a power density value of $242.8 \mathrm{~W} \mathrm{~kg}^{-1}$, the energy density value was $17 \mathrm{~W} \mathrm{~h} \mathrm{~kg}^{-1}$.

\section{Iron sulfide}

Being reasonably priced, exhibiting very good electrical conductivity and possession of an excess of active sites; Iron sulfide $\left(\mathrm{FeS}_{2}\right)$ has attracted the interest of many researchers for its potential use in energy storage applications (Zhao et al. 2017a; Pham et al. 2018; Yu et al. 2018). A huge number of supercapacitors based on nanocomposites of $\mathrm{FeS}_{2}$ as an electrode material has been prepared with a variety of interesting morphologies and structures. For example, 


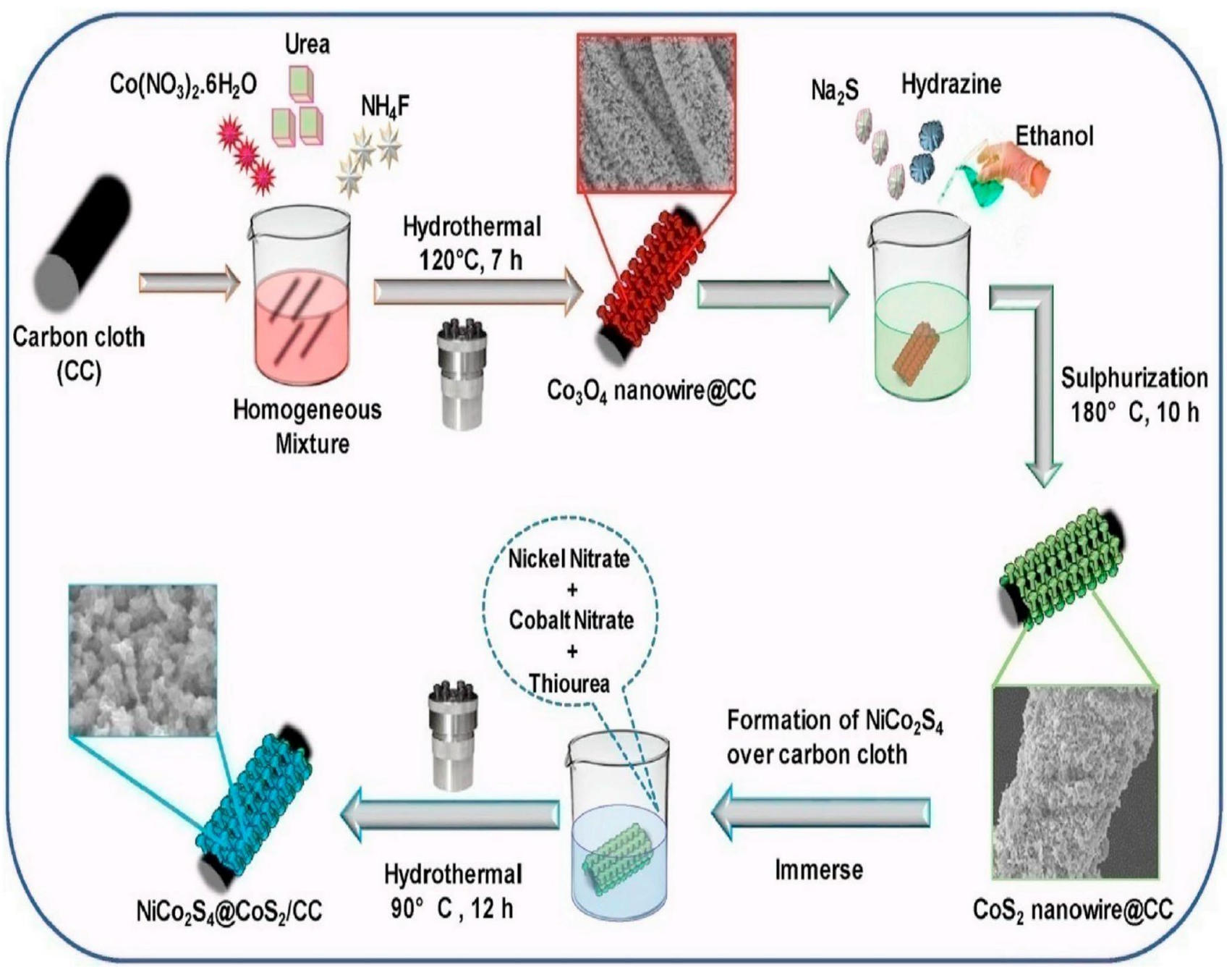

Fig. 12 Fabrication of nickel cobaltite sulfide/cobalt sulfide coated over carbon cloth, a part of carbon cloth was put in the uniform solution and hydrothermally heated at $120{ }^{\circ} \mathrm{C}$, and gradually reduced its temperature. The Cobalt tetraoxide $\mathrm{Co}_{3} \mathrm{O}_{4}$ /carbon cloth was washed

Balakrishnan et al. (2019) fabricated a hybrid supercapacitor based on $\mathrm{FeS}_{2}$ and reduced graphene oxide hydrothermally. The prepared hybrid supercapacitor has a much greater value of specific capacitance than pure iron sulfide (i.e. the difference was $21.28 \mathrm{mF} \mathrm{cm}^{-2}$ under the same conditions). Moreover, at a current density of $0.3 \mathrm{~mA} \mathrm{~cm}^{-2}$, it retained $90 \%$ of its initial SC after 10,000 cycles. Figure 13 shows the Scanning electron microscopy images for the preparation of the hybrid supercapacitor.

\section{Molybdenum disulfide}

Molybdenum disulfide $\left(\mathrm{MoS}_{2}\right)$ is cheap, simply prepared in nanosheet form, with very high surface area and excellent conductivity (Liu et al. 2016c; Palsaniya et al. 2018). Owing to these excellent properties, $\mathrm{MoS}_{2}$ and its based and dried overnight. Lastly, the samples were calcined at $200{ }^{\circ} \mathrm{C}$. Adapted with permission from Govindasamy et al. (2019b). Copyright (2019) Elsevier

nanocomposites have been extensively studied in many fields and applications like catalysis, energy storage, supercapacitors, and Li-ion batteries (Osman et al. 2018).

As an example, Yang et al. (2017) used the hydrothermal reaction pathway with glucose assistance to manufacturing an asymmetric supercapacitor in the form of hierarchical arrays of NiS based on $\mathrm{MoS}_{2}$ nanosheets on a backbone of carbon nanotubes as shown in Fig. 14. The prepared electrode demonstrated a specific capacitance of $676.4 \mathrm{~F} \mathrm{~g}^{-1}$ at $1 \mathrm{~A} \mathrm{~g}^{-1}$, and the retained capacitance percentage was $100 \%$ at a current density of $5 \mathrm{~A} \mathrm{~g}^{-1}$ after 2000 cycles.

Another example is the hydrothermal synthesis of a novel nanocomposite based supercapacitor of molybdenum disulfide and graphitic carbon nitrides $\left(\mathrm{g}-\mathrm{C}_{3} \mathrm{~N}_{4} / \mathrm{MoS}_{2}\right)$ in a flower-like shape by $\mathrm{Xu}$ et al. (2019b). The specific capacitance of this supercapacitor was $532.7 \mathrm{~F} \mathrm{~g}^{-1}$ at $1 \mathrm{~A} \mathrm{~g}^{-1}$ and 

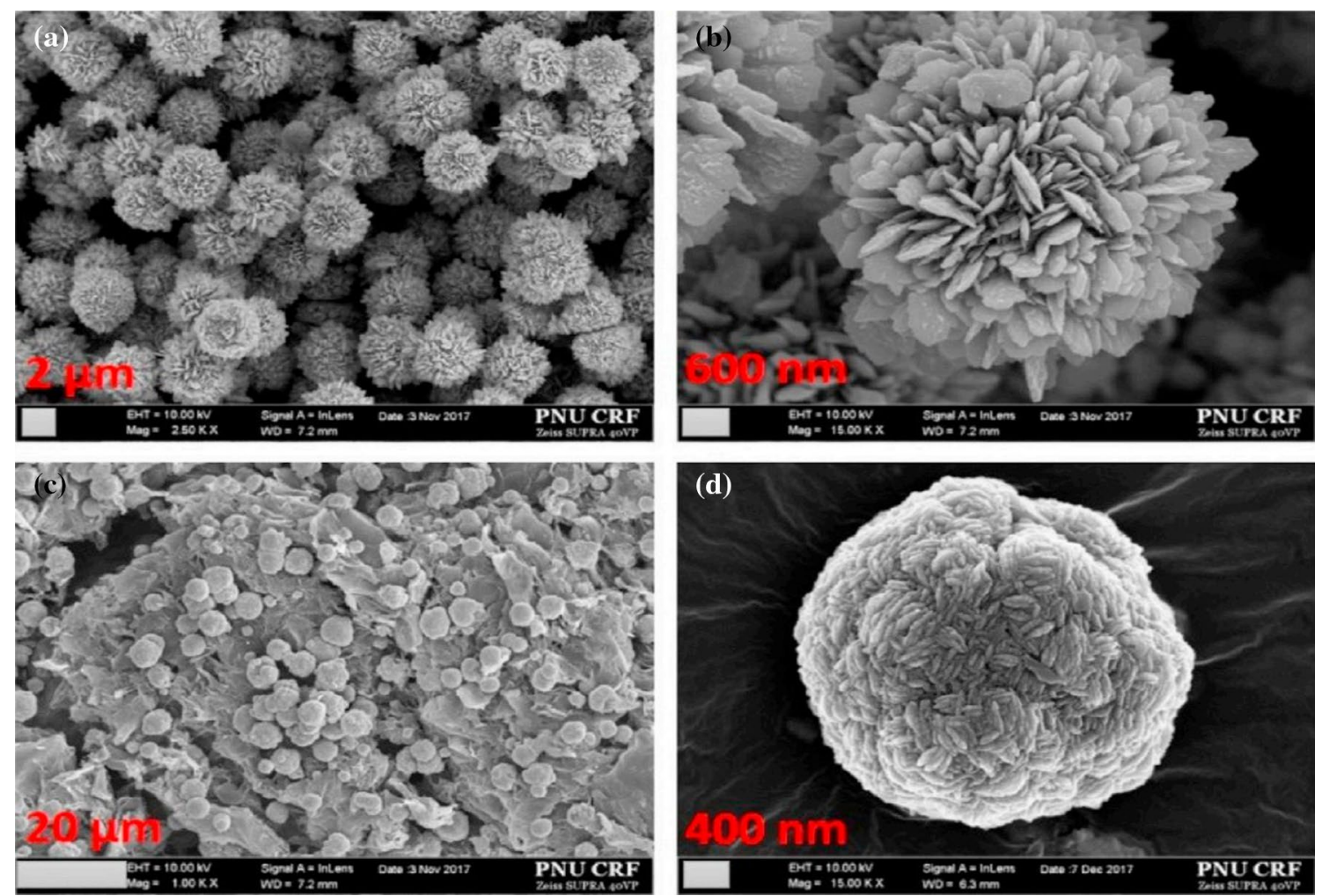

Fig. 13 Scanning electron microscopy (SEM) images of $\mathbf{a}, \mathbf{b}$ micro flowers of $\mathrm{FeS}_{2}$ and $\mathbf{c}, \mathbf{d}$ microspheres of reduced graphene oxide/iron sulfide hybrid. Adapted with permission from Balakrishnan et al. (2019). Copyright (2019) Elsevier

retained $88.6 \%$ of its initial capacitance after 1000 lifecycles. These superior electrochemical characteristics may be attributed to the synergetic action between flowery $\mathrm{MoS}_{2}$ and the nanosheets of graphitic carbon nitrides (see Fig. 15) which facilitates the charge-transfer process.

Recently, Manuraj et al. have synthesized a nanocomposite hetero-structured solid substance comprising of molybdenum sulfide, $\mathrm{MoS}_{2}$, nanowires and $\mathrm{RuO}_{2}$ nanoparticles via hydrothermal and chemical reduction procedures. In a three-electrode configuration, the $\mathrm{MoS}_{2}-\mathrm{RuO}_{2}$ hybrid electrode shows specific capacitance reached $972 \mathrm{~F} \mathrm{~g}^{-1}$ at $1 \mathrm{~A} \mathrm{~g}^{-1}$, while, in the two-electrode configuration, its presented $719 \mathrm{~F} \mathrm{~g}^{-1}$ as presented in Fig. 16. Furthermore, the symmetric supercapacitor based on the composite electrodes shows high cycling stability which retained about $100 \%$ from its initial capacitance after $10 \times 10^{3}$ cycles. Also, $\mathrm{MoS}_{2}-\mathrm{RuO}_{2}$ hybrid electrode shows a high energy density value of $35.92 \mathrm{~W} \mathrm{~h} \mathrm{~kg}^{-1}$ at power density $0.6 \mathrm{~kW} \mathrm{~kg}^{-1}$.

\section{Tin sulfides}

Many studies have been performed to enhance the electrochemical activities of tin sulfides $\left(\mathrm{SnS}\right.$ and $\left.\mathrm{SnS}_{2}\right)$, using numerous approaches. These include doping with metal or non-metal ions, use of a carbon matrix and material engineering into nanostructured forms of tin sulfides and their nanocomposites to apply them as electrochemical capacitors (Mishra et al. 2017; Wang et al. 2015b). Recently, Parveen et al. (2018) synthesized $\mathrm{SnS}_{2}$ in different shapes of nanostructures like; ellipsoid tin sulfide $\left(\mathrm{EL}-\mathrm{SnS}_{2}\right)$, flower-like $\left(\mathrm{FL}-\mathrm{SnS}_{2}\right)$, and sheet-like $\left(\mathrm{SL}-\mathrm{SnS}_{2}\right)$. The flower-like tin sulfide was the most promising one with small pore size and larger surface area exhibiting $432 \mathrm{~F} \mathrm{~g}^{-1}$ of specific capacitance at $1 \mathrm{~A} \mathrm{~g}^{-1}$.

\section{Manganese sulfide}

Manganese sulfide (MnS) is also a cheap, naturally abundant, environmentally friendly compound and theoretically, it possesses a high supercapacitance and electrical conductivity due to its various oxidation states ranging from +2 to +7 (Palaniyandy et al. 2019). Moreover, $\mathrm{MnS}$ is present in three polymorphic states: $\alpha$ (cubic), $\beta$ (cubic), and $\gamma$ (hexagonal) (Yu et al. 2016). A summary of some of the most recent work on MnS is shown in Table 2. 


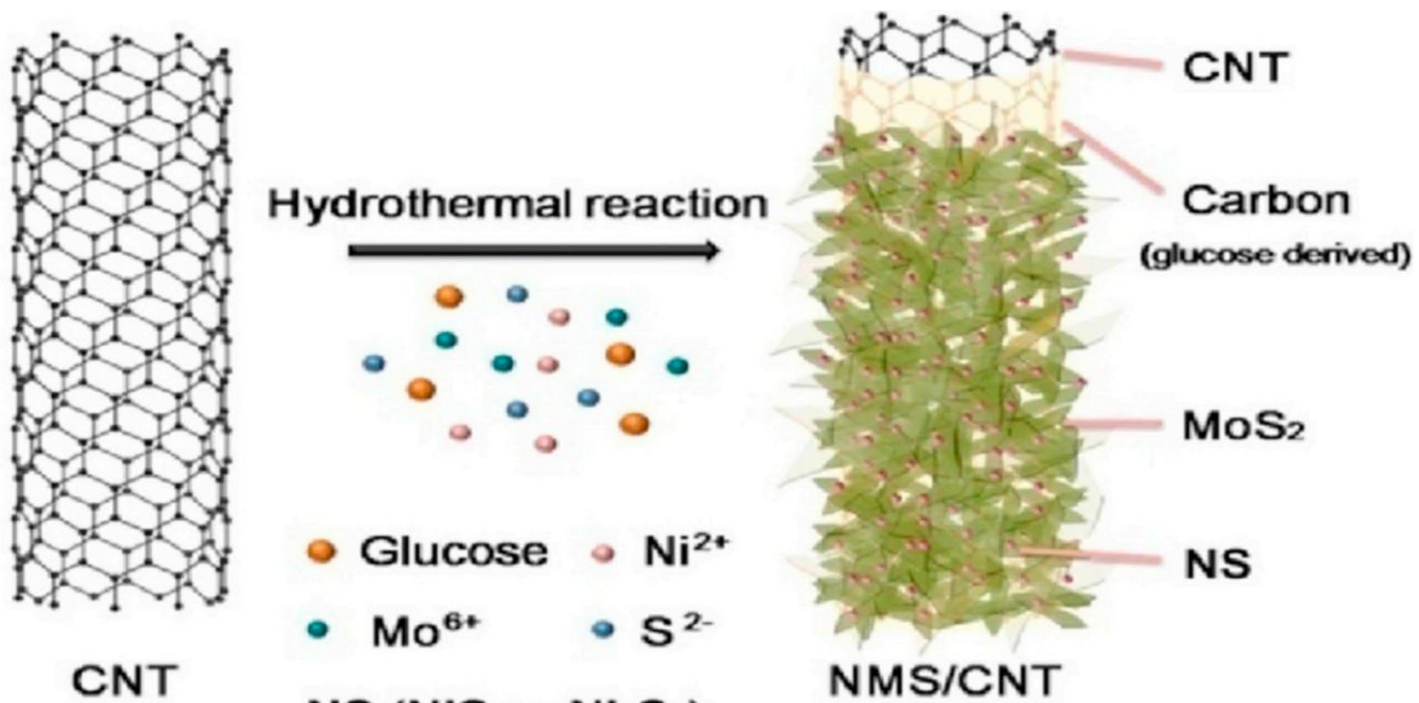

$\mathrm{NS}\left(\mathrm{NiS}\right.$ or $\left.\mathrm{Ni}_{9} \mathrm{~S}_{8}\right)$

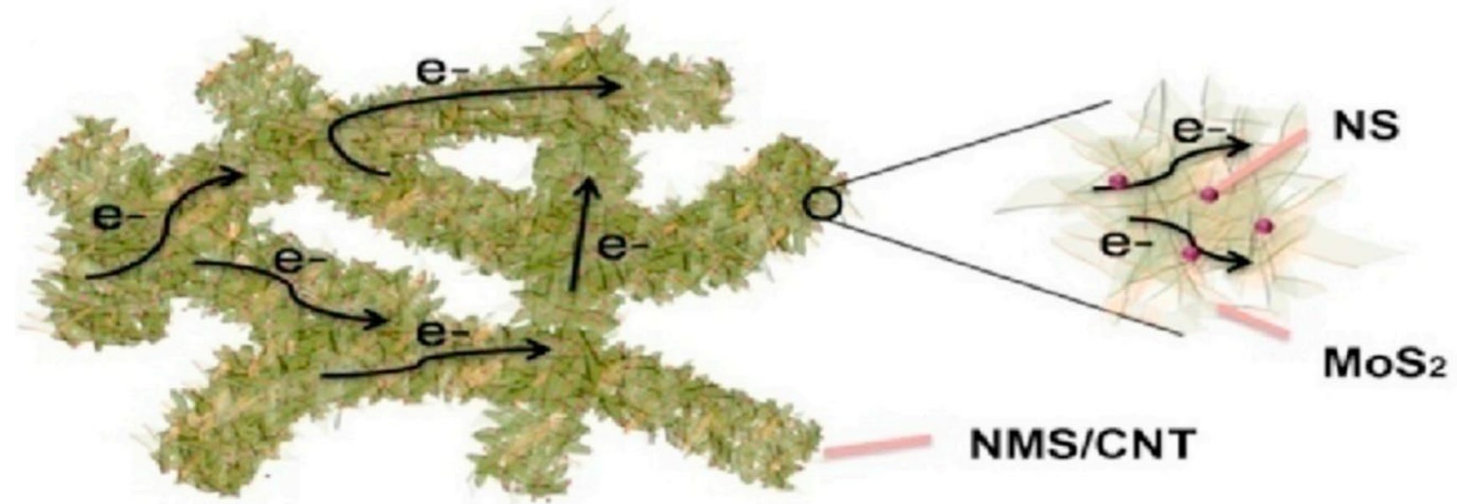

Fig. 14 a Synthesis process of nickel sulfide/molybdenum disulfide/carbon nanotube. b Pathways of electron transport in the nickel sulfide/ molybdenum disulfide/carbon nanotube supercapacitor. Adapted with permission from Yang et al. (2017). Copyright (2017) Elsevier

\section{Tungsten sulfide}

Tungsten sulfide $\left(\mathrm{WS}_{2}\right)$ is again abundant in nature and is found as hexagonal crystals belonging to the space group $\mathrm{P} 63 / \mathrm{mmc}$ (Eftekhari 2017). $\mathrm{WS}_{2}$ crystals are forming relatively brittle, restacked nanosheets with slight electrical conductivity, restricting its application as a supercapacitor (Xia et al. 2018). Hence, many approaches have been followed to enhance its electrochemical performance, such as doping with binary metals, non-metals, carbon materials and conducting polymers (Xia et al. 2018).

Choudhary et al. (Choudhary et al. 2016) prepared a nanowire of tungsten( $\mathrm{VI})$ oxide $\left(\mathrm{WO}_{3}\right)$ and comprised it with a tungsten sulfide $\left(\mathrm{WO}_{3} / \mathrm{WS}_{2}\right)$ core/shell structure. They used a foil of $\mathrm{W}$ and applied $\mathrm{KOH}$ on its surface to promote its oxidation at $650{ }^{\circ} \mathrm{C}$, forming a hexagonal single crystal of $\mathrm{WO}_{3}\left(\mathrm{~h}-\mathrm{WO}_{3}\right)$, followed by a sulfurization process to finally form $\mathrm{h}-\mathrm{WO}_{3} / \mathrm{WS}_{2}$ nanowires as illustrated in Fig. 17. The synthesized hybrid supercapacitor demonstrated superior electrochemical characteristics and losses a negligible percentage of its primary capacity after 30,000 lifecycles.

\section{Carbon materials for supercapacitors applications}

Carbon-derived materials hold numerous benefits such as great quantity in raw materials (abundance), thermal stability, value-added chemicals, ease of processing and modification. Consequently, they have displayed countless attention and high potential in different energy-related applications (Wang et al. 2008, 2018a; Meng et al. 2014; Li et al. 2016c; Jiang et al. 2012; Osman et al. 2019a, b, 2020a, b; Osman 2020; Chen et al. 2019b). Mesoporous carbon materials consider as promising targets for advanced applications due to 

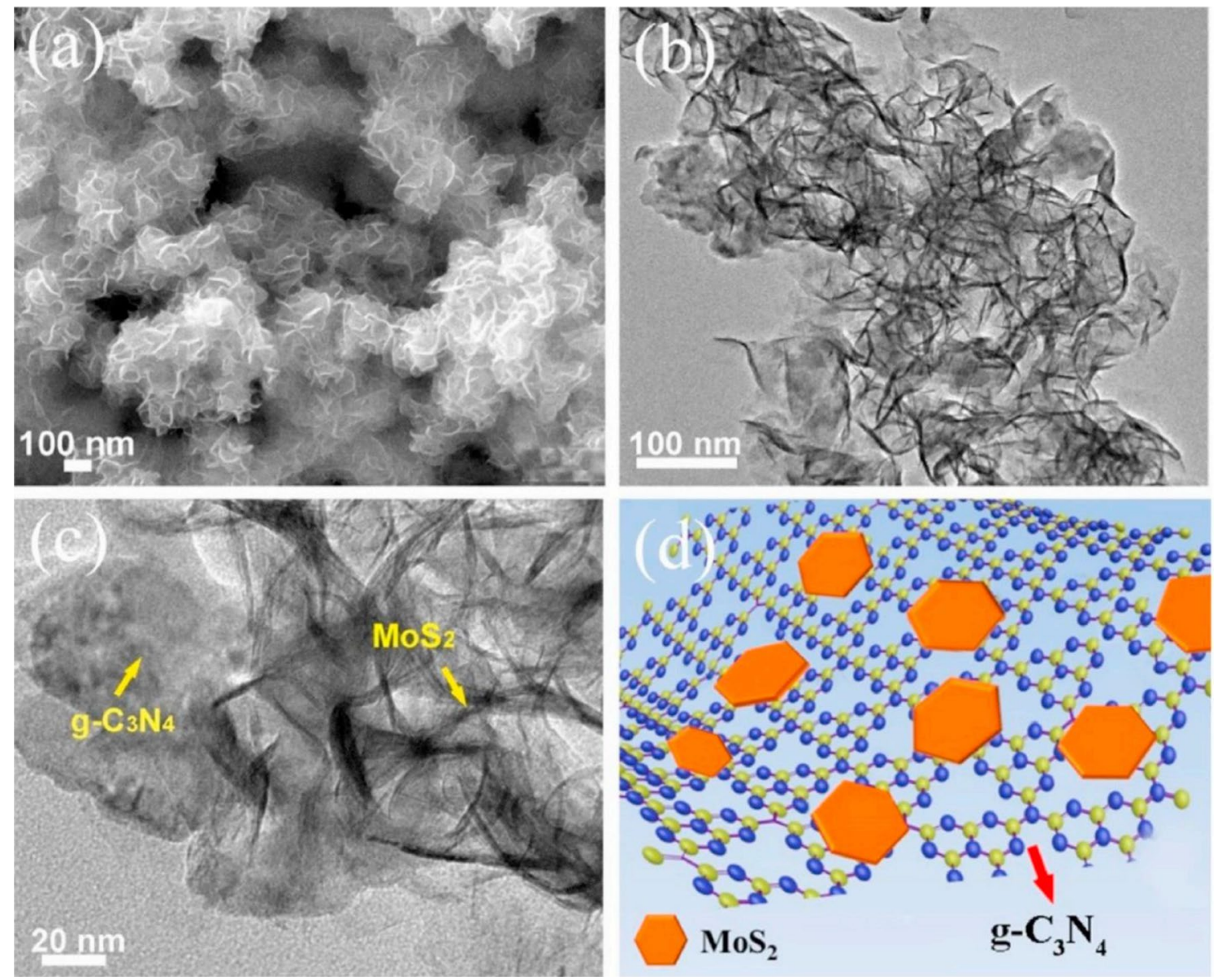

Fig. 15 Morphology of a graphitic carbon nitrides g- $\mathrm{C}_{3} \mathrm{~N}_{4} / \mathrm{MoS}_{2}$ nanocomposite. a SEM image, b TEM, c HR-TEM, d sketch of the

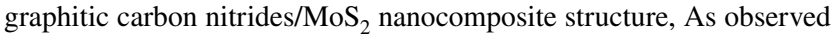
in the figure, a more uniform and smooth molybdenum disulfide structure performed without aggregation. TEM confirms that most of the molybdenum disulfide are grown on the surface of the gra-

phitic carbon nitrides, which means that the graphitic carbon nitrides sheets give beneficial sites for the extension of the molybdenum disulfide. SEM: scanning electron microscopy, TEM: transmission electron microscopy, HR: high resolution. Adapted with permission from Xu et al. (2019b). Copyright (2019) Elsevier

their exceptional features, which enables them to engross universal apprehension over the last few decades (Qiang et al. 2017; Zhang et al. 2017c; Sevilla et al. 2017; Wang et al. 2006; Hooch Antink et al. 2018). There are several physical arrangements for mesoporous carbons, containing nanoparticles (Górka and Jaroniec 2010; Lee et al. 2011), nanosheets (Wang et al. 2018a; Li et al. 2017b; Ding et al. 2013), nanotubes (Osman et al. 2019a, 2020a, b; Guo et al. 2011), nanofibers (Wu et al. 2015b), etc., which can adapt with several categories of industrial applications. Additionally, there are different pore size in the nanostructures of mesoporous carbons, including micropores, mesopores and macropores, which is of noteworthy prominence for their supercapacitor application.

Several preparation pathways, including nanocasting direct synthesis strategies, were studied to obtain

mesoporous carbon materials with different particle structures via several reaction pathways (Fig. 18), which all have separate advantages and disadvantages (Li et al. 2016d).

Nanocasting method showed the best ability, compared to direct synthesis methods, to prepare unvarying dispersed mesopores in carbon materials with attracting features to produce highly symmetric mesoporous inorganic solid substances as appropriate templates in the energy storage application. Interestingly, mesoporous inorganic substances can reproduce their internal structures in nanoporous carbon construction with promising distributed mesoporosity. The nanocasting techniques for creating mesoporous carbons involved two advanced procedures, the hard and soft templating approaches. Commonly, the nanocasting technique is a relatively predictable templating progression. Notwithstanding that the synthesized mesoporous carbons have 

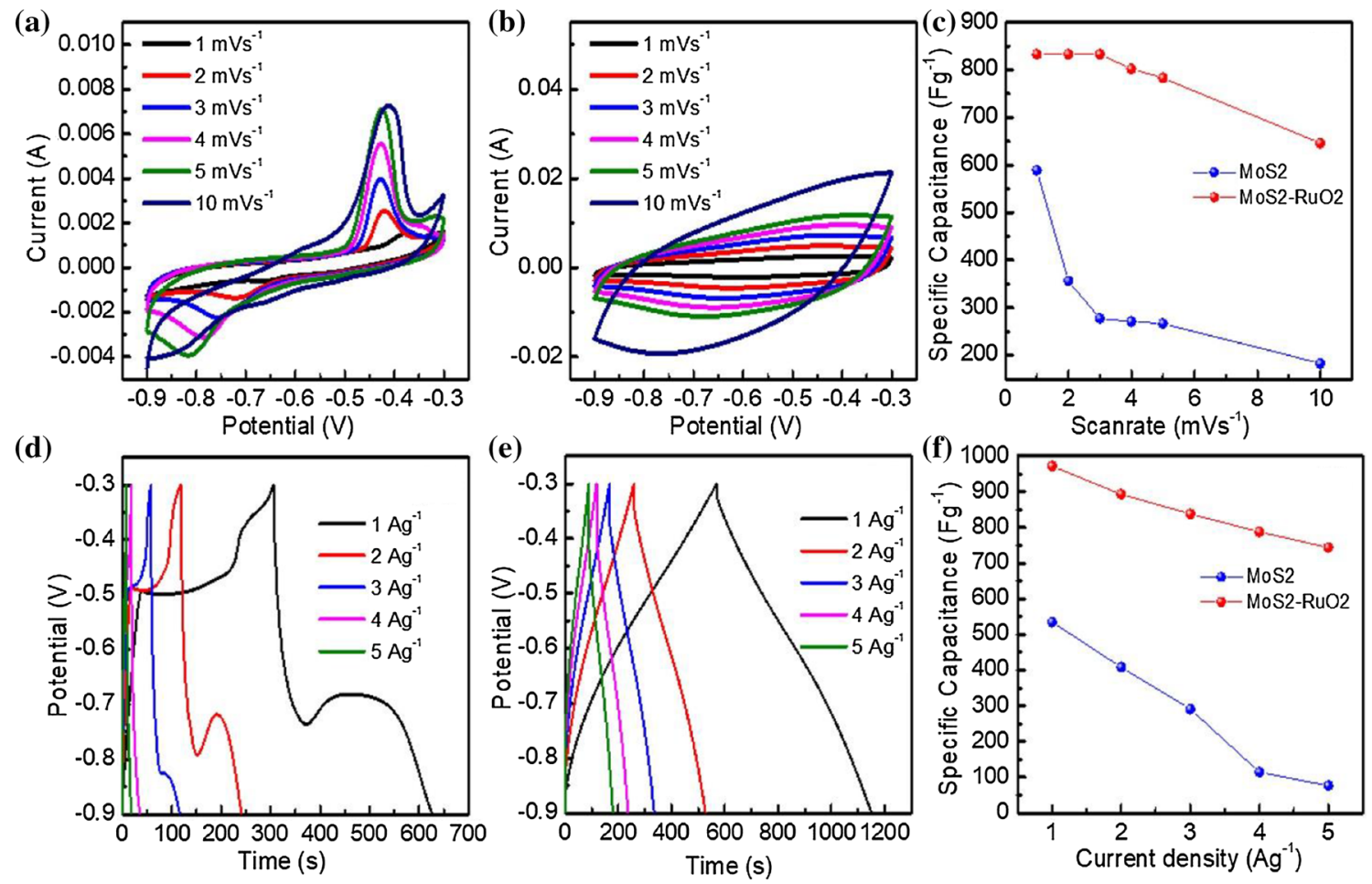

Fig. 16 Cyclic voltammetry curves of $\mathbf{a}$ molybdenum disulfide, $\mathbf{b}$ molybdenum disulfide/ruthenium oxide, $\mathbf{c}$ capacitance s. scan rate. c Galvanostatic charge/discharge curves of $\mathbf{d}$ molybdenum disulfide, e molybdenum disulfide/ruthenium oxide, $\mathbf{f}$ capacitance versus current density, The figures display two of redox peaks, which designate the high performance of the material matching to the introduction

inimitable physical and chemical features, the large-scale production has quite a few drawbacks.

\section{High-performance supercapacitor electrode material via 3D carbon nanosheet}

Due to the high cost of graphene and its derivatives, threedimensional porous carbon nanosheets, synthesized via facile methods, have received attention for large scale applications because of their largely opened layer, excellent electronic transportation ability and high specific surface area. The obtained results for the prepared bark-based carbon demonstrates specific features toward a remarkable function in energy storage. The as-fabricated bark-based carbon-700-based supercapacitors exhibit an enchanting capacitance, exceptional capacitance retention and attractive energy density for supercapacitor application systems. The universal method of preparing a carbon nanosheet from bark, which exists in a tree's construction is considered as environmentally friendly (as schematically shown in Fig. 19) ( $\mathrm{Li}$ et al. 2019e), can be very succinct, as the bark contains the periderm as well as the lignin that oriented hollow tube and parentage of electrons. At higher scan rates, peaks are moved as the ions may be bound over the electrode surface, at lower scan rates, the ions could efficiently migrate into the internal active positions. Adapted with permission from Manuraj et al. (2020), Copyright (2020) Elsevier

cellulose fibers (Keränen et al. 2013; Sun et al. 2018b; Chen et al. 2018b).

Additionally, Fig. 20a illustrates the main structure of untreated bark that confirms the distribution of both abundant pores as well as different sizes in the raw materials, The pollen can be activated and the spherical porous structure of the materials kept as it is while using copper salts in the preparation pathway to synthesize the carbon nanosheet (Liu et al. 2018g). The SEM images of bark-based carbon $700{ }^{\circ} \mathrm{C}$ are demonstrated in Fig. 20b, c, which confirm the formation of a typical flower-like carbon structure with outstanding three-dimensional vertical carbon structure through the carbon nanosheet. As well, the TEM image (Fig. 20d) was used for the confirmation of the texture for the obtained barkbased carbon samples, in which the thin nanosheet structure of the as-prepared material was undeniably discovered. In addition, the $\mathrm{N}_{2}$ adsorption-desorption measurements, through curves in Fig. 20e, were used to detect the obtained samples microstructures. The hysteresis loops located at 0.4-0.9P/P disclose the existence of the mesoporous (Chen et al. 2019c). The pore size distribution curves premeditated from density-functional theory are represented in Fig. 20f, 
Table 2 Electrochemical characteristics of transition metals sulfide-based nanocomposite electrodes for supercapacitor applications

\begin{tabular}{|c|c|c|c|c|c|c|}
\hline Electrode composition & Electrolyte & $\begin{array}{l}\text { Current } \\
\text { density } \\
\left(\mathrm{A} \mathrm{g}^{-1}\right)\end{array}$ & Capacitance $\left(\mathrm{F} \mathrm{g}^{-1}\right)$ & $\begin{array}{l}\text { Percent of } \\
\text { retained specific } \\
\text { capacitance \%/ } \\
\text { no. of cycles }\end{array}$ & $\begin{array}{l}\text { Energy density }\left(\mathrm{W} \mathrm{h} \mathrm{kg}^{-1}\right) / \text { power } \\
\text { density }\left(\mathrm{kW} \mathrm{kg}^{-1}\right)\end{array}$ & References \\
\hline $\mathrm{MoS}_{2}$-graphene & $1 \mathrm{M} \mathrm{Na}_{2} \mathrm{SO}_{4}$ & 1 & 243 & $92.3 / 1000$ & $73.5 / 19.8$ & Huang et al. (2013a) \\
\hline $\mathrm{MoS}_{2} /$ carbon aerogel & $1 \mathrm{M} \mathrm{Na}_{2} \mathrm{SO}_{4}$ & 1 & 260 & $96 / 500$ & & Huang et al. (2015b) \\
\hline $\begin{array}{l}\text { 3D-MoS } \mathrm{M}_{2} / \text { chemically modi- } \\
\text { fied graphene }\end{array}$ & $1 \mathrm{M} \mathrm{Na}_{2} \mathrm{SO}_{4}$ & 1 & 257 & $93 / 1000$ & & Yang et al. (2015) \\
\hline s- $\mathrm{MoS}_{2} /$ carbon nanotube & $1 \mathrm{M} \mathrm{Na}_{2} \mathrm{SO}_{4}$ & 0.1 & 108 & & $7.4 / 3.7$ & Khawula et al. (2016) \\
\hline $\begin{array}{l}\mathrm{MoS}_{2} / \text { graphene foam } / / \\
\text { activated carbon prepared } \\
\text { via expanded graphite }\end{array}$ & & 1 & 59 & $95 / 2000$ & $16 / 0.758$ & Masikhwa et al. (2017) \\
\hline $\begin{array}{l}\mathrm{MoS}_{2} @ \text { microporous } \\
\text { carbons }\end{array}$ & $1 \mathrm{M} \mathrm{H}_{2} \mathrm{SO}_{4}$ & 10 & 145 & $98 / 3000$ & & Weng et al. (2015) \\
\hline $\begin{array}{l}\text { Reduced graphene oxide/ } \\
\mathrm{MoS}_{2}\end{array}$ & & $10 \mathrm{mV} \mathrm{s}^{-1}$ & 298.81 & $90 / 500$ & & Murugan et al. (2017) \\
\hline $\mathrm{MoS}_{2} /$ carbon & & 1.6 & 182.9 & $94.1 / 1000$ & & Fan et al. (2015) \\
\hline Carbonnanotube@ $\mathrm{MoS}_{2}$ & $1 \mathrm{M} \mathrm{Na}_{2} \mathrm{SO}_{4}$ & 1 & 350.6 & $85 / 10,000$ & & Sun et al. (2017) \\
\hline $\begin{array}{l}\text { G wrapped carbon nano- } \\
\text { tube@ } \mathrm{MoS}_{2}\end{array}$ & & 5 & 350 & $94.3 / 10,000$ & & Sun et al. (2017) \\
\hline $\begin{array}{l}\mathrm{MoS}_{2} / \text { mesoporous carbon } \\
\text { spheres }\end{array}$ & $1 \mathrm{M} \mathrm{Na}_{2} \mathrm{SO}_{4}$ & 1 & 411 & $93.2 / 1000$ & & Zhang et al. (2017a) \\
\hline Carbon fiber tows/MoS ${ }_{2}$ & & 10 & 272 & & $3.67 \mathrm{~mW} \mathrm{~h} \mathrm{~g}^{-1} / 33.21 \mathrm{~m} \mathrm{~W} \mathrm{~g}^{-1}$ & Gao et al. (2016b) \\
\hline $\begin{array}{l}\text { Carbon nanotube } / \mathrm{MoS}_{2} \\
\text { nanosheet }\end{array}$ & & $5 \mathrm{mV} \mathrm{s}^{-1}$ & $135 \mathrm{~F} \mathrm{~cm}^{-3}$ & $95 / 1000$ & & Luo et al. (2015) \\
\hline $\begin{array}{l}\mathrm{MoS}_{2} / \text { reclaimed carbon } \\
\quad \text { fiber }\end{array}$ & $1 \mathrm{M} \mathrm{Na}_{2} \mathrm{SO}_{4}$ & 4 & 112 & $78.6 / 2000$ & & Zhao et al. (2018) \\
\hline $\begin{array}{l}\mathrm{MoS}_{2} / \text { reduced graphene } \\
\text { oxide membrane on } \mathrm{Ti} \\
\text { Mesh 5:1 }\end{array}$ & & $10 \mathrm{mV} \mathrm{s}^{-1}$ & $17.6 \mathrm{mF} \mathrm{s}^{-1}$ & & & Lamberti (2018) \\
\hline $\begin{array}{l}\mathrm{MoS}_{2} / \text { three-dimensional } \\
\text { graphene }\end{array}$ & & $20 \mathrm{~A} \mathrm{~cm}^{-2}$ & $2080 \mathrm{~F} \mathrm{~cm}^{-2}$ & $116.83 / 5000$ & & Han et al. (2018) \\
\hline $\mathrm{MoS}_{2} @ \mathrm{~N}$-doped carbon & $1 \mathrm{M} \mathrm{Na}_{2} \mathrm{SO}_{4}$ & 1 & 276 & $90.59 / 6000$ & & Cui et al. (2017) \\
\hline $\begin{array}{l}\text { Electrospun } \mathrm{MoS}_{2} @ \mathrm{C} \\
\text { nanofiber }\end{array}$ & $6 \mathrm{M} \mathrm{KOH}$ & $5 \mathrm{mV} \mathrm{s}^{-1}$ & 355.6 & $93 / 2000$ & & $\begin{array}{l}\text { Kumuthini et al. } \\
\text { (2017) }\end{array}$ \\
\hline $\begin{array}{l}\mathrm{MoS}_{2} \text {-coated three-dimen- } \\
\text { sional graphene network }\end{array}$ & $3 \mathrm{M} \mathrm{KOH}$ & 10 & 1825.24 & $110.57 / 4000$ & & Zhou et al. (2017) \\
\hline $\mathrm{MoS}_{2} /$ graphene nanobelts & & 2 & 278.07 & $96.75 / 1000$ & & Jia et al. (2017) \\
\hline $\mathrm{MoS}_{2} / \mathrm{C}$ & & 2 & 290 & $132.4 / 5000$ & & Lee et al. (2017) \\
\hline $\begin{array}{l}\mathrm{MoS}_{2} / \text { reduced graphene } \\
\text { oxide }\end{array}$ & $2 \mathrm{M} \mathrm{KOH}$ & $10 \mathrm{mV} \mathrm{s}^{-1}$ & 314.5 & $80.02 / 1000$ & & Awasthi et al. (2018) \\
\hline $\mathrm{MoS}_{2}$-hollow carbon sphere & $0.5 \mathrm{M} \mathrm{H}_{2} \mathrm{SO}_{4}$ & 1 & 334 & $87 / 5000$ & & Liu et al. (2018d) \\
\hline Carbon- $\mathrm{MoS}_{2}$ nano-sphere & $3 \mathrm{M} \mathrm{KOH}$ & 10 & 760 & $96 / 20,000$ & & Luo et al. (2018) \\
\hline $\begin{array}{l}\mathrm{MoS}_{2} \text { nanosheets/reduced } \\
\text { graphene oxide }\end{array}$ & $1 \mathrm{M} \mathrm{H}_{2} \mathrm{SO}_{4}$ & $100 \mathrm{mV} \mathrm{s}^{-1}$ & $1.501 \mathrm{mF} \mathrm{cm}{ }^{-2}$ & $95 / 1000$ & $5.71 \mathrm{~mW} \mathrm{~h} \mathrm{~cm}^{-2} / 54.1 \mathrm{~mW} \mathrm{~cm}^{-2}$ & Dutta and De (2018) \\
\hline Polyaniline/ $\mathrm{MoS}_{2}$ & $1 \mathrm{M} \mathrm{H}_{2} \mathrm{SO}_{4}$ & 1 & 575 & $98 / 500$ & $265 / 18$ & Huang et al. (2013b) \\
\hline Polyaniline/A-MOS ${ }_{2}$ & $1 \mathrm{M} \mathrm{H}_{2} \mathrm{SO}_{4}$ & 10 & 405 & $88.6 / 1000$ & $33.33 / 8$ & Zha et al. (2017) \\
\hline Polyaniline/C-MoS 2 & & 10 & 367 & $75.1 / 1000$ & $27.11 / 8$ & Zha et al. (2017) \\
\hline $\mathrm{MoS}_{2} /$ polypyrrole & & 5 & 157 & $96.47 / 1000$ & & Chang et al. (2017) \\
\hline M-MoS 2 /polyaniline & & 10 & 337 & $80 / 2500$ & & Ansari et al. (2017) \\
\hline $\mathrm{C}-\mathrm{MoS}_{2}$ /polyaniline & & 1 & 225.15 & & & Ansari et al. (2017) \\
\hline $\begin{array}{l}\text { C-MoS } 2 \text { /polyaniline- } 20 \\
\quad \mathrm{MoS}_{2} 20 \%\end{array}$ & $1 \mathrm{M} \mathrm{H}_{2} \mathrm{SO}_{4}$ & 8 & 480 & $90 / 900$ & & Wang et al. (2017b) \\
\hline $\begin{array}{l}\mathrm{MoS}_{2} / \text { polypyrrole- } \\
\text { nanowire } \\
\mathrm{MoS}_{2}: \text { polypyrrole } 1: 5\end{array}$ & & 3 & 350 & $82 / 2000$ & $25.5 / 266.3$ & Chen et al. (2017a) \\
\hline $\begin{array}{l}\mathrm{MoS}_{2}-\text { polyethylenedioxy- } \\
\text { thiophene three configu- } \\
\text { ration cells }\end{array}$ & $2 \mathrm{M} \mathrm{HCl}$ & $5 \mathrm{mV} \mathrm{s}^{-1}$ & 452 & & & $\begin{array}{l}\text { Alamro and Ram } \\
\text { (2017) }\end{array}$ \\
\hline $\begin{array}{l}\mathrm{MoS}_{2}-\text { polyethylenedioxy- } \\
\text { thiophene two configura- } \\
\text { tion cells }\end{array}$ & $2 \mathrm{M} \mathrm{HCl}$ & $5 \mathrm{mV} \mathrm{s}^{-1}$ & 360 & & & $\begin{array}{l}\text { Alamro and Ram } \\
\text { (2017) }\end{array}$ \\
\hline
\end{tabular}


Table 2 (continued)

\begin{tabular}{|c|c|c|c|c|c|c|}
\hline Electrode composition & Electrolyte & $\begin{array}{l}\text { Current } \\
\text { density } \\
\left(\mathrm{A} \mathrm{g}^{-1}\right)\end{array}$ & Capacitance $\left(\mathrm{F} \mathrm{g}^{-1}\right)$ & $\begin{array}{l}\text { Percent of } \\
\text { retained specific } \\
\text { capacitance \%/ } \\
\text { no. of cycles }\end{array}$ & $\begin{array}{l}\text { Energy density }\left(\mathrm{W} \mathrm{h} \mathrm{kg}{ }^{-1}\right) / \text { power } \\
\text { density }\left(\mathrm{kW} \mathrm{kg}^{-1}\right)\end{array}$ & References \\
\hline $\mathrm{MoS}_{2} /$ polyaniline@C & & 1 & 668 & $80 / 10,000$ & & Yang et al. (2016) \\
\hline $\mathrm{MoS}_{2} /$ polypyrrole & & $10 \mathrm{mV} \mathrm{s}^{-1}$ & 720 & $85 / 4000$ & & Tang et al. (2015b) \\
\hline $\begin{array}{l}\text { 1T- } \mathrm{MoS}_{2} / \text { polyaniline- } 62 \\
60 \mathrm{~g} \mathrm{MoS}_{2}\end{array}$ & $0.5 \mathrm{M} \mathrm{H}_{2} \mathrm{SO}_{4}$ & 10 & 340 & $91 / 2000$ & & Zhao et al. (2017b) \\
\hline $\begin{array}{l}\text { Macroporous-polyaniline } \\
\text { nanorods@ } \mathrm{MoS}_{2}\end{array}$ & & 10 & 433 & $86.7 / 2000$ & $43.3 / 6$ & Wang et al. (2017c) \\
\hline Polypyrrole/MoS ${ }_{2}$ & & 1 & 895.6 & $98 / 10,000$ & $3.774 / 252.8$ & Lian et al. (2017) \\
\hline Polyaniline-few-layer $\mathrm{MoS}_{2}$ & & 10 & 200 & $93 / 2000$ & $128 / 0.494$ & Raghu et al. (2018) \\
\hline $\mathrm{Ni}_{3} \mathrm{~S}_{2} @ \mathrm{MoS}_{2}$ & & 8 & 791.2 & $91 / 2000$ & & Wang et al. (2014c) \\
\hline $\mathrm{Ni}_{3} \mathrm{~S}_{4}-\mathrm{MoS}_{2}$ & & 10 & 733 & $78 / 20,000$ & & Luo et al. (2017) \\
\hline $\mathrm{Co}_{3} \mathrm{~S}_{4}-\mathrm{MoS}_{2}$ & & 10 & 754 & $82 / 20,000$ & & Luo et al. (2017) \\
\hline $\mathrm{Ni}_{3} \mathrm{~S}_{4}-\mathrm{MoS}_{2} / / \mathrm{AC}$ & & 10 & 60 & $86.2 / 10,000$ & $18.75 / 7.5$ & Luo et al. (2017) \\
\hline $\mathrm{Bi}_{2} \mathrm{~S}_{3} / \mathrm{MoS}_{2}$ & & $10 \mathrm{~mA} \mathrm{~cm}^{-2}$ & $1.48 \mathrm{~F} \mathrm{~cm}^{-2}$ & $96.5 / 1000$ & & Ma et al. (2017) \\
\hline $\mathrm{MoS}_{2} / \mathrm{Mn}_{3} \mathrm{O}_{4}$ & & 1 & 172 & $69.3 / 2000$ & & Wang et al. (2016c) \\
\hline $\mathrm{MoS}_{2}-\mathrm{NiO}$ & & 2 & 1030 & $101.9 / 9000$ & & Wang et al. (2017d) \\
\hline $\mathrm{MoS}_{2}-\mathrm{Co}_{3} \mathrm{O}_{4}$ & & 1 & 1088.5 & $93 / 6000$ & & Wang et al. (2017d) \\
\hline $\mathrm{MoS}_{2}-\mathrm{WO}_{3}$ & $1 \mathrm{M} \mathrm{Na}_{2} \mathrm{SO}_{4}$ & 2 & 468 & $95 / 5000$ & & Gong et al. (2018) \\
\hline $\mathrm{NiFe}_{2} \mathrm{O}_{4} / \mathrm{MoS}_{2}$ & $1 \mathrm{M} \mathrm{KOH}$ & 5 & 300 & $90.7 / 3000$ & & Zhao et al. (2017c) \\
\hline $\begin{array}{l}\mathrm{Bi}_{2} \mathrm{~S}_{3} \text { nanorod } / \mathrm{MoS}_{2} \\
\text { nanosheet }\end{array}$ & & 10 & 1553 & $92.65 / 5000$ & & Fang et al. (2017) \\
\hline $\mathrm{MoS}_{2} @ 3 \mathrm{D}-\mathrm{Ni}$-foam & & $3 \mathrm{~mA} \mathrm{~cm}^{-2}$ & $3400 \mathrm{mF} \mathrm{cm}^{-2}$ & $82 / 4500$ & & Nandi et al. (2017) \\
\hline $\mathrm{Ag} @ \mathrm{MoS}_{2}$ & $2 \mathrm{M} \mathrm{KOH}$ & 1 & 980 & $97 / 5000$ & & Wu et al. (2017) \\
\hline $\begin{array}{l}\mathrm{MoS}_{2} / \mathrm{CoS}_{2} \text { nanotube } \\
\text { arrays }\end{array}$ & & $1 \mathrm{~mA} \mathrm{~cm}^{-2}$ & $142.5 \mathrm{mF} \mathrm{cm}^{-2}$ & $92.7 / 1000$ & $13.25 / 0.05$ & Wang et al. (2017e) \\
\hline $\begin{array}{l}\mathrm{MoS}_{2} \text { nanosheet arrays@ } \\
\text { Ti plate }\end{array}$ & $1 \mathrm{M} \mathrm{KCl}$ & 1 & 133 & $93 / 1000$ & $11.11 / 0.53$ & Wang et al. (2017f) \\
\hline $\begin{array}{l}\mathrm{MoS}_{2} \text { nanospheres }\left(\mathrm{SiO}_{2} @\right. \\
\left.\quad \mathrm{MoS}_{2}\right)\end{array}$ & $2 \mathrm{M} \mathrm{KOH}$ & 1 & 683 & $85.1 / 10,000$ & & Gao et al. (2018b) \\
\hline $\mathrm{CoS}_{2} @ \mathrm{MoS}_{2}$ & & 5 & 885 & $84.76 / 10,000$ & & Huang et al. (2018b) \\
\hline $\mathrm{MoS}_{2}-\mathrm{CoSe}_{2}$ & & 20 & 896 & $91.3 / 5000$ & $60 / 0.800$ & Fang et al. (2018) \\
\hline Ag nano-wires- $\mathrm{MoS}_{2}$ & & $0.05 \mathrm{~V}^{-1}$ & $18 \mathrm{mF} \mathrm{cm}^{-2}$ & $96.3 / 20,000$ & & Li et al. (2019c) \\
\hline $\begin{array}{l}\mathrm{Ni}_{3} \mathrm{~S}_{2} @ \mathrm{MoS}_{2}(0.75 \mathrm{mM} \\
\text { sodium molybdate }\end{array}$ & $6 \mathrm{M} \mathrm{KOH}$ & 5 & 836.4 & $75.8 / 1250$ & & Huang et al. (2017b) \\
\hline $\begin{array}{l}\mathrm{MoS}_{2}-\mathrm{rGO} / \text { multiwall } \\
\text { carbon nanotube }\left(\mathrm{MoS}_{2}\right. \\
6.3 \%)\end{array}$ & $1 \mathrm{M} \mathrm{H}_{2} \mathrm{SO}_{4}$ & $0.5 \mathrm{~A} \mathrm{~cm}^{-3}$ & $4.8 \mathrm{~F} \mathrm{~cm}^{-3}$ & $100 / 7000$ & & Sun et al. (2015) \\
\hline $\mathrm{MoS}_{2} /$ polyaniline/graphene & & 20 & 476 & $96 / 2000$ & & Sha et al. (2016) \\
\hline $\begin{array}{l}\text { Polyaniline/carbon nano- } \\
\text { tube/MoS } \\
2, \mathrm{MoS}_{2} 5 \%\end{array}$ & & 10 & 289 & $68 / 2000$ & & Thakur et al. (2017) \\
\hline $\mathrm{C} @ \mathrm{Ni}_{3} \mathrm{~S}_{2} @ \mathrm{MoS}_{2}$ & & 10 & 1388 & $71.4 / 10,000$ & & Li et al. (2016b) \\
\hline $\mathrm{Ni}_{3} \mathrm{~S}_{4} @ \mathrm{MoS}_{2}$ & & 5 & 833 & $96.2 / 5000$ & & Huang et al. (2017a) \\
\hline $\begin{array}{c}\mathrm{MoS}_{2} / \mathrm{Fe}_{3} \mathrm{O}_{4} / \text { physical } \\
\text { exfoliated graphite }\end{array}$ & $1 \mathrm{M} \mathrm{H}_{2} \mathrm{SO}_{4}$ & 6 & 665 & $96 / 2200$ & & $\begin{array}{l}\text { Sarno and Troisi } \\
\text { (2017) }\end{array}$ \\
\hline $\begin{array}{l}\text { Polyindole/carbon black/ } \\
\mathrm{MoS}_{2}\end{array}$ & & 1 & 442 & $92.3 / 5000$ & $2.11 / 0.135$ & Majumder et al. (2017) \\
\hline $\begin{array}{l}\mathrm{MoS}_{2} @ \text { carbon nanotube/ } \\
\text { reduced graphene oxide }\end{array}$ & $1 \mathrm{M} \mathrm{H}_{2} \mathrm{SO}_{4}$ & $10 \mathrm{~mA} \mathrm{~cm}^{-2}$ & $96 \mathrm{mF} \mathrm{cm}^{-2}$ & $96.6 / 10,000$ & & Wang et al. (2017g) \\
\hline $\begin{array}{l}\mathrm{MoS}_{2} \text { nanowires/ } / \mathrm{NiCo}_{2} \mathrm{O}_{4} / / \\
\text { active carbon }\end{array}$ & & 6 & 21 & $98.2 / 8000$ & $18.4 / 12.002$ & Wen et al. (2018) \\
\hline $\mathrm{NiCo}_{2} \mathrm{~S}_{4}-\mathrm{C}-\mathrm{MoS}_{2}$ & $6 \mathrm{M} \mathrm{KOH}$ & 0.5 & 1601 & $75 / 2000$ & $27.7 / 0.400$ & Zhang et al. (2018a) \\
\hline $\begin{array}{l}\mathrm{MoS}_{2} / \mathrm{MoO}_{x} @ \text { activated } \\
\text { carbon cloth }\end{array}$ & & $5 \mathrm{mV} \mathrm{s}^{-1}$ & 230 & $128 / 1500$ & & Sari and Ting (2018) \\
\hline $\mathrm{C} @ \mathrm{MoS}_{2} / \mathrm{Ni}_{3} \mathrm{~S}_{4}$ & $2 \mathrm{M} \mathrm{KOH}$ & 20 & 468.6 & $136.7 / 10,000$ & & Qin et al. (2018) \\
\hline $\begin{array}{l}\text { Multwall carbon nanotube/ } \\
\text { polyaniline/ } \mathrm{MoS}_{2}\end{array}$ & $1 \mathrm{M} \mathrm{H}_{2} \mathrm{SO}_{4}$ & 1 & 490 & $73.71 / 3000$ & & Zhang et al. (2018c) \\
\hline $\begin{array}{l}\text { Reduced graphene oxide- } \\
\mathrm{MOS}_{2}-\mathrm{WS}_{2}\end{array}$ & & 1 & 365 & $70 / 3000$ & $15 / 0.373$ & Lin et al. (2018) \\
\hline
\end{tabular}


Table 2 (continued)

\begin{tabular}{|c|c|c|c|c|c|c|}
\hline Electrode composition & Electrolyte & $\begin{array}{l}\text { Current } \\
\text { density } \\
\left(\mathrm{A} \mathrm{g}^{-1}\right)\end{array}$ & Capacitance $\left(\mathrm{F} \mathrm{g}^{-1}\right)$ & $\begin{array}{l}\text { Percent of } \\
\text { retained specific } \\
\text { capacitance } \% / \\
\text { no. of cycles }\end{array}$ & $\begin{array}{l}\text { Energy density }\left(\mathrm{W} \mathrm{h} \mathrm{kg}^{-1}\right) / \text { power } \\
\text { density }\left(\mathrm{kW} \mathrm{kg}^{-1}\right)\end{array}$ & References \\
\hline $\begin{array}{l}\mathrm{Co}_{9} \mathrm{~S}_{8} @ \mathrm{~N}-\mathrm{C} @ \mathrm{MoS}_{2} \\
\text { Nanocubes }\end{array}$ & $3 \mathrm{M} \mathrm{KOH}$ & 10 & 410 & $101.7 / 20,000$ & & Hou et al. (2018) \\
\hline $\begin{array}{l}\mathrm{MoS}_{2} / \text { polyaniline/reduced } \\
\text { graphene oxide hierarchi- } \\
\text { cal nanosheets }\end{array}$ & & 10 & 330.7 & $81.9 / 40,000$ & & Chao et al. (2018) \\
\hline $3 \mathrm{D} \mathrm{Ni}_{3} \mathrm{~S}_{2}$ & $1 \mathrm{M} \mathrm{KOH}$ & 5 & 626.1 & & & Zhang et al. (2014) \\
\hline $\mathrm{Ni}_{3} \mathrm{~S}_{2}$ & $1 \mathrm{M} \mathrm{NaOH}$ & 50 & 1000 & & & Chen et al. (2017b) \\
\hline $\mathrm{NiCoS}$ & $1 \mathrm{M} \mathrm{KCl}$ & 5 & 1513 & & & Sami et al. (2017) \\
\hline Carbon nanofibers-NiS & $2 \mathrm{M} \mathrm{KOH}$ & 1 & $177.1 \mathrm{~mA} \mathrm{~h} \mathrm{~g}^{-1}$ & & & Xu et al. (2018b) \\
\hline $\mathrm{NiCo}_{2} \mathrm{~S}_{4}$ & $1 \mathrm{M} \mathrm{KOH}$ & $10 \mathrm{mV} \mathrm{s}^{-1}$ & 1155 & & & Kim et al. (2017) \\
\hline $\mathrm{NiCo}_{2} \mathrm{~S}_{4} @ \mathrm{NiO}$ & $3 \mathrm{M} \mathrm{KOH}$ & $1 \mathrm{~mA} \mathrm{~cm}^{-2}$ & $12.2 \mathrm{~F} \mathrm{~cm}^{-2}$ & & & Huang et al. (2016c) \\
\hline Quadruple-shelled $\mathrm{CoS}_{2}$ & $2 \mathrm{M} \mathrm{KOH}$ & 1 & 375.2 & & & Jia et al. (2019) \\
\hline Hollow $\mathrm{CoS}_{2}$ & $2 \mathrm{M} \mathrm{KOH}$ & 1 & 936 & & & Ren et al. (2019) \\
\hline Hierarchical $\mathrm{CoS}_{2}$ & $2 \mathrm{M} \mathrm{KOH}$ & 1 & 718.7 & & & Xing et al. (2014a) \\
\hline Octahedron-shaped $\mathrm{CoS}_{2}$ & $2 \mathrm{M} \mathrm{KOH}$ & 1 & 236.5 & & & Xing et al. (2014b) \\
\hline 3D hollow $\mathrm{CoS}_{2}$ & $6 \mathrm{M} \mathrm{KOH}$ & 0.5 & 499 & & & Zeng et al. (2017) \\
\hline $\mathrm{CoS}_{2}$ nanodendrites & $2 \mathrm{M} \mathrm{KOH}$ & 1 & 311.06 & & & Zhang et al. (2016d) \\
\hline $\begin{array}{l}\mathrm{CoS}_{2} \text {-multiwall carbon } \\
\text { nanotube }\end{array}$ & $1 \mathrm{M} \mathrm{NaOH}$ & 1 & 1486 & & & Sarkar et al. (2018) \\
\hline Pyrite $\mathrm{FeS}_{2}$ & $1 \mathrm{M} \mathrm{Na}_{2} \mathrm{SO}_{4}$ & 3 & 317.8 & & & Chen et al. (2016b) \\
\hline $\mathrm{FeS}_{2}$-carbon nanofiber & $30 \mathrm{wt} \% \mathrm{KOH}$ & 1 & 406 & & & $\begin{array}{l}\text { Sridhar and Park } \\
\text { (2018) }\end{array}$ \\
\hline $\mathrm{FeS}_{2}$ & $2 \mathrm{M} \mathrm{KOH}$ & 1 & $515 \mathrm{C} \mathrm{g}^{-1}$ & & & Sun et al. (2019a) \\
\hline $\mathrm{Co}_{0.33} \mathrm{Fe}_{0.67} \mathrm{~S}_{2}$ & $3 \mathrm{M} \mathrm{KOH}$ & $2 \mathrm{mV} \mathrm{s}^{-1}$ & $310.2 \mathrm{C} \mathrm{g}^{-1}$ & & & Liu et al. (2018a) \\
\hline $\mathrm{FeS}_{2} @ \mathrm{Fe}_{2} \mathrm{O}_{3}$ & $1 \mathrm{M} \mathrm{Li}_{2} \mathrm{SO}_{4}$ & 1 & 255 & & & Gao et al. (2016a) \\
\hline $\begin{array}{l}\text { Reduced graphene oxide/ } \\
\text { FeS }\end{array}$ & $2 \mathrm{M} \mathrm{KOH}$ & 3.3 & 300 & & & Zhao et al. (2017d) \\
\hline $\begin{array}{l}\mathrm{MoS}_{2} @ \text { carbon nanotubes/ } \\
\mathrm{Ni}\end{array}$ & $1 \mathrm{M} \mathrm{Na}_{2} \mathrm{SO}_{4}$ & 1 & 512 & & & Sun et al. (2019b) \\
\hline $\begin{array}{l}\mathrm{MoS}_{2} / \text { carbon nanotubes- } \\
\mathrm{MnO}_{2}\end{array}$ & $1 \mathrm{M} \mathrm{Na}_{2} \mathrm{SO}_{4}$ & 0.8 & 365.6 & & & Zhang et al. (2019b) \\
\hline $\mathrm{MoS}_{2} /$ carbon nanotubes & $1 \mathrm{M} \mathrm{Na}_{2} \mathrm{SO}_{4}$ & 1 & 402 & & & Chen et al. (2018a) \\
\hline $\begin{array}{l}\mathrm{MoS}_{2} / \mathrm{C} @ \text { reduced gra- } \\
\text { phene oxide }\end{array}$ & $1 \mathrm{M} \mathrm{Na}_{2} \mathrm{SO}_{4}$ & 1 & 340.0 & & & Liu et al. (2019) \\
\hline $\begin{array}{l}\text { NiS/MoS } \mathrm{MN}_{2} \mathrm{~N} \text {-reduced } \\
\text { graphene oxide }\end{array}$ & $6 \mathrm{M} \mathrm{KOH}$ & 1 & 2225 & & & Xu et al. (2019c) \\
\hline $\begin{array}{l}\mathrm{MoS}_{2} \text {-reduced graphene } \\
\text { oxide@ polypyrrole } \\
\text { nanotubes }\end{array}$ & $1 \mathrm{M} \mathrm{KCl}$ & 1 & 1561.25 & & & $\begin{array}{l}\text { Sarmah and Kumar } \\
\text { (2018) }\end{array}$ \\
\hline $\begin{array}{l}\mathrm{MoS}_{2} / \text { poly(ethyleneimine- } \\
\text { graphene oxide }\end{array}$ & $6 \mathrm{M} \mathrm{KOH}$ & 1 & 153.9 & & & Liu et al. (2018e) \\
\hline $\mathrm{MoO}_{2} / \mathrm{MoS}_{2}$ & $1 \mathrm{M} \mathrm{Na}_{2} \mathrm{SO}_{4}$ & 1 & 383.5 & & & Zhang et al. (2016e) \\
\hline $\mathrm{MoS}_{2} / 3 \mathrm{D}-\mathrm{Ni}$ foam & $\mathrm{Na}_{2} \mathrm{SO}_{4} / \mathrm{PVA}$ solid & 1.3 & 34.1 & & & Mishra et al. (2019) \\
\hline $\begin{array}{l}\mathrm{Co}_{9} \mathrm{~S}_{8} / \alpha-\mathrm{MnS} @ \mathrm{~N}-\mathrm{C} @ \\
\mathrm{MoS}_{2}\end{array}$ & $2 \mathrm{M} \mathrm{KOH}$ & 1 & 1938 & & & Kandula et al. (2018) \\
\hline Carbon black-SnS & $1 \mathrm{M} \mathrm{KOH}$ & 0.1 & 201 & & & Barik et al. (2019) \\
\hline $\begin{array}{l}\mathrm{SnS}_{2} / \text { reduced graphene } \\
\text { oxide }\end{array}$ & $2 \mathrm{M} \mathrm{Na}_{2} \mathrm{SO}_{4}$ & 0.5 & 500 & & & Chauhan et al. (2017) \\
\hline $\begin{array}{l}\text { SnS/S-doped graphene } \\
\text { hybrid nanosheets }\end{array}$ & $6 \mathrm{M} \mathrm{KOH}$ & 1 & 642 & & & Liu et al. (2017b) \\
\hline $\mathrm{Mo}-\mathrm{SnS}_{2}$ & $3.5 \mathrm{M} \mathrm{KOH}$ & 1 & 213 & & & Ma et al. (2015) \\
\hline $\begin{array}{l}\mathrm{Mn}-\mathrm{SnS}_{2} \text {-graphene } \\
\text { aerogels }\end{array}$ & $6 \mathrm{M} \mathrm{KOH}$ & $5 \mathrm{mV} \mathrm{s}^{-1}$ & 523 & & & Chu et al. (2018) \\
\hline $\begin{array}{l}\mathrm{SnS}_{2} @ \mathrm{Cu}_{2} \mathrm{O} / \text { reduced } \\
\text { graphene oxide }\end{array}$ & $1 \mathrm{M} \mathrm{KOH}$ & 0.6 & 1800 & & & Hatui et al. (2017) \\
\hline $\mathrm{SnS}_{2}-\mathrm{SnO}_{2}$ & $0.5 \mathrm{M} \mathrm{Na}_{2} \mathrm{SO}_{4}$ & 2 & 149 & & & Asen et al. (2019) \\
\hline
\end{tabular}


Table 2 (continued)

\begin{tabular}{|c|c|c|c|c|c|c|}
\hline Electrode composition & Electrolyte & $\begin{array}{l}\text { Current } \\
\text { density } \\
\left(\mathrm{A} \mathrm{g}^{-1}\right)\end{array}$ & Capacitance $\left(\mathrm{F} \mathrm{g}^{-1}\right)$ & $\begin{array}{l}\text { Percent of } \\
\text { retained specific } \\
\text { capacitance } \% / \\
\text { no. of cycles }\end{array}$ & $\begin{array}{l}\text { Energy density }\left(\mathrm{W} \mathrm{h} \mathrm{kg}^{-1}\right) / \text { power } \\
\text { density }\left(\mathrm{kW} \mathrm{kg}^{-1}\right)\end{array}$ & References \\
\hline $\mathrm{SnNi}_{2} \mathrm{~S}_{4}$ & $1 \mathrm{M} \mathrm{KOH}$ & 2 & 1484 & & & $\begin{array}{l}\text { Chandrasekaran et al. } \\
\text { (2018) }\end{array}$ \\
\hline $\mathrm{MnS} / \mathrm{GO}-\mathrm{NH}_{3}$ & $2 \mathrm{M} \mathrm{KOH}$ & 0.25 & 391 & & & Tang et al. (2015c) \\
\hline $\begin{array}{l}\text { Graphene nanosheets- } \\
\text { manganese sulfide }\end{array}$ & $3.5 \mathrm{M} \mathrm{KOH}$ & 2 & 792 & & & Vignesh et al. (2019) \\
\hline $\begin{array}{l}\mathrm{MnS} @ \text { reduced graphene } \\
\text { oxide/Ni }\end{array}$ & $3 \mathrm{M} \mathrm{KOH}$ & 0.5 & 2220 & & & $\begin{array}{l}\text { Naveenkumar and } \\
\text { Paruthimal Kalaig- } \\
\text { nan (2018) }\end{array}$ \\
\hline $\begin{array}{l}\gamma \text {-MnS/reduced graphene } \\
\text { oxide }\end{array}$ & $\begin{array}{l}1 \mathrm{MKOH} / 0.5 \mathrm{MNa}_{2} \\
\mathrm{~S} .9 \mathrm{H} 2 \mathrm{O} / 0.5 \mathrm{M} \text { Sulfur } \\
\text { powders }\end{array}$ & 5 & 802 & & & Li et al. (2015) \\
\hline $\begin{array}{l}\gamma \text {-MnS/reduced graphene } \\
\text { oxide }\end{array}$ & $2 \mathrm{M} \mathrm{KOH}$ & 1 & 548 & & & Zhang et al. (2017b) \\
\hline $\begin{array}{l}\gamma \text {-MnS/reduced graphene } \\
\text { oxide }\end{array}$ & $6 \mathrm{M} \mathrm{KOH}$ & 1 & 1009 & & & $\begin{array}{l}\text { Ranganatha and } \\
\text { Munichandraiah } \\
\text { (2018) }\end{array}$ \\
\hline$\gamma-\mathrm{MnS}$ & $0.5 \mathrm{M} \mathrm{Na}_{2} \mathrm{SO}_{4}$ & 0.2 & 378 & & & Li et al. (2019d) \\
\hline $\begin{array}{l}\alpha-\mathrm{MnS} / \mathrm{N} \text {-reduced gra- } \\
\text { phene oxide }\end{array}$ & $3 \mathrm{M} \mathrm{KOH}$ & 1 & 934 & & & Quan et al. (2016) \\
\hline $\mathrm{ZnS} / \mathrm{MnS}$ & $3 \mathrm{M} \mathrm{KCl}$ & $2\left(\mathrm{mV} \mathrm{s}^{-1}\right)$ & 884 & & & Arul et al. (2018) \\
\hline $\mathrm{CuS} / \mathrm{MnS}$ & $3 \mathrm{M} \mathrm{KOH}$ & 1 & 1144 & & & Liu et al. (2018f) \\
\hline $\mathrm{WS}_{2}$ & $1 \mathrm{M} \mathrm{H}_{2} \mathrm{SO}_{4}$ & $40 \mathrm{mV} \mathrm{s}^{-1}$ & $86 \mathrm{mF} \mathrm{cm}^{-2}$ & & & Liang et al. (2018) \\
\hline $\begin{array}{l}\mathrm{WS}_{2} / \text { reduced graphene } \\
\text { oxide }\end{array}$ & $1 \mathrm{MKOH} / 0.5 \mathrm{MKCl}$ & $1 \mathrm{mV} \mathrm{s}^{-1}$ & 2508 & & & Tu et al. (2016) \\
\hline $\begin{array}{l}\mathrm{WS}_{2} \text {-multiwall carbon } \\
\text { nanotubes }\end{array}$ & $1 \mathrm{M} \mathrm{H}_{2} \mathrm{SO}_{4}$ & 1 & 760 & & & Gao et al. (2018c) \\
\hline $\begin{array}{l}\mathrm{WS}_{2} / \mathrm{N}, \mathrm{S} \text {-reduced graphene } \\
\text { oxide }\end{array}$ & $6 \mathrm{MKOH}$ & 1 & 1562 & & & Xu et al. (2019d) \\
\hline $\mathrm{ZnWO}_{4} / \mathrm{WS}_{2}$ & $3 \mathrm{MKOH}$ & 3 & 1281 & & & Anitha et al. (2019) \\
\hline $\mathrm{CuWS} / \mathrm{Ni}$ & $1 \mathrm{M} \mathrm{Li}_{2} \mathrm{SO}_{4}$ & $10 \mathrm{~mA}$ & 2667 & & & $\begin{array}{l}\text { Pazhamalai et al. } \\
\text { (2019) }\end{array}$ \\
\hline
\end{tabular}

which demonstrated the same pore structure with pores sizes principally determined at 0.8 and $1.2 \mathrm{~nm}$. Reasonably, the current study can conclude that both treatment temperatures, as well as the hard template, are indispensable factors toward obtaining porous carbon nanosheets via biomass.

The performance of the as-prepared carbon nanosheet can be obtained via the electrochemical activity measurements by applying these materials in the supercapacitor. Figure 21a confirmed the obtained capacity ability curves of bark-based carbon at $700{ }^{\circ} \mathrm{C}$, which proposes remaining capacitor activities of the bark-based carbon at $700{ }^{\circ} \mathrm{C}$. Moreover, the galvanostatic charge/discharge, as well as specific capacitances results, are developed to consider the capacity implemented as an electrode material (Fig. 21b, c). The results indicated that bark-based carbon at $700{ }^{\circ} \mathrm{C}$ displays an exceptional capacitance around $\sim 340.0 \mathrm{~F} \mathrm{~g}^{-1}$, comparing to that of bark-based carbon at $600{ }^{\circ} \mathrm{C}$ around $\sim 290 \mathrm{~F} \mathrm{~g} \mathrm{~g}^{-1}$ and finally bark-based carbon at $800{ }^{\circ} \mathrm{C}$ displays capacity $309 \mathrm{~F} \mathrm{~g}^{-1}$. Likewise, Fig. 21d illustrates the electrochemical impedance spectroscopy analysis of barkbased carbon samples, which indicates related plot profiles that contain a semicircle and around vertical lines in low and high frequencies, respectively, to result in significantly better supercapacitor behavior. Thus, it can be established that bark-based carbon at $700{ }^{\circ} \mathrm{C}$ owns the lower values of resistance about $0.26 \mathrm{O}$, indicating the exceptional electrochemical performance of the $3 \mathrm{D}$ porous carbon nanosheet.

\section{Graphene-based nanocomposites for supercapacitor applications}

Graphene which exists in hexagonal assembly can be defined as a two-dimensional single layer of $s p^{2}$ hybridized carbonaceous atoms. The number and arrangement of graphene layers determine the electronic characteristics of graphene. Additionally, interlayer ordering and the layer number with a different thickness could affect the chemical and physical characteristics of graphene. 


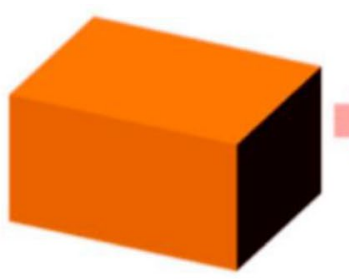

1. W foil

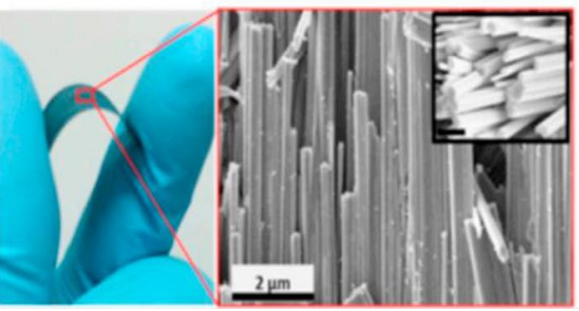

Fig. 17 a Fabrication of tungsten oxide/tungsten sulfide composites. b A photo of the studied system and nanowires image, The nanowires like structures of the crystalline Tungsten(VI) oxide are sulfurized in furnace supporting by sulfur medium via the chemical vapor deposi-

Graphene has received great research attention owing to its extraordinary features. For instance, its powerful mechanical strength, porosity, large specific area, improved conductivity, and electrochemically active nature. Different physical and chemical pathways can be used to attain graphene as well as several composite materials between graphene and other compounds that make graphene appropriate to improve the electrochemical activity of different materials for numerous applications like lithium-ion batteries and supercapacitors. Graphene-derived materials possess a monumental potential for applications in broad areas such as conversion, electronics, energy storage and catalysis (Sun et al. 2011; Chen and Hsu 2011; Liu et al. 2012; Yu et al. 2012; Shih et al. 2013; Zhang et al. 2012; Hou et al. 2013; Wang et al. 2013a; Girishkumar et al. 2010; Jin et al. 2013; Hassoun et al. 2012; Pan et al. 2013; Yang et al. 2013; Gao et al. 2012; Wang et al. 2013b; Zhang et al. 2013b; Zhu et al. 2012; Luo et al. 2012; Xu et al. 2013; Lin et al. 2013; Huang et al. 2012; Wang et al. 2011). Scheme 1 described the information on characteristics of graphene that enables its wide range of applications, and the features of graphene for different applications.

Graphene and their composites were widely employed for progress in supercapacitors. Where it has got significant attention, attributed to its exceptionally surface area achieved $\sim 2542.0 \mathrm{~m}^{2} \mathrm{~g}^{-1}$ and its unique electrical conduction characteristic. Also, one layer of $\mathrm{G}$ performs extraordinary capacitance around $\sim 20.0 \mu \mathrm{F} \mathrm{cm} \mathrm{cm}^{-1}$ which is larger than other composites based on $\mathrm{C}$ materials. The highest energy density of the supercapacitors depends on various

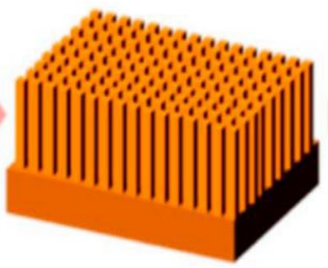

3. $\mathrm{WO}_{3}$ nanowires

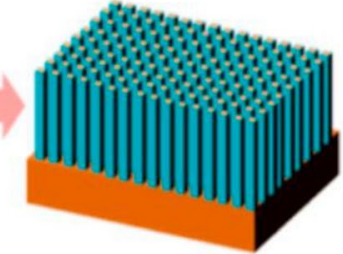

4. WO $\mathrm{WS}_{2}$ core/shell nanowires tion, which transforms the outside surface of the Tungsten(VI) oxide to two-dimensional Tungsten sulfide. Adapted with permission from Choudhary et al. (2016). Copyright (2016) American Chemical Society

parameters namely; electrode nature, current collectors, separators, type, and density of electrolyte, working voltage window of the cell, and the retention performance (El-Kady et al. 2016). Graphene, as an electrode material, has a large enrichment to the performance of the supercapacitor. It owns numerous obvious shapes in all four dimensions as quantum dots, wires (one dimensional), films (two dimensional), and monoliths (three dimensional). Further to the four-dimensional self-healing structure (Yadav and Devi 2020).

Graphene oxide material along with the reduced graphene oxide species are examined as possible electrode materials for supercapacitors because of their remarkably great specific surface area, superior electrical conductivity, and exceptional mechanical properties (Wang et al. 2009; Ke and Wang 2016). Michael et al. have synthesized an asymmetrical supercapacitor device based on graphene oxide via a simple screen-printing method. The capacitance was increased from 0.82 to $423 \mathrm{~F} \mathrm{~g}^{-1}$, after graphene oxide incorporation. The device exhibited a power density of about $13.9 \mathrm{~kW} \mathrm{~kg}^{-1}$ at the energy density up to11.6 $\mathrm{W} \mathrm{h} \mathrm{kg}^{-1}$. Also, Zhang et al. (2016f) have successfully synthesized a reduced graphene oxide/nickel foam electrode via flame-induced reduction of dry graphene oxide onto nickel foam. The produced composite material offers a specific capacitance that reaches $228.6 \mathrm{~F} \mathrm{~g}^{-1}$ at $1 \mathrm{~A} \mathrm{~g}^{-1}$ and retained high cycling stability up to $94.7 \%$ after 10,000 cycles. The excellent performance is ascribed to the cross-linking disordered network along with the random distribution of the resulted pores that allows fast transport of ions to the active sites (Zhang et al. 2016f). Recently, Sahoo et al. (2016) have synthesized a novel 
(a) Soft-templating method

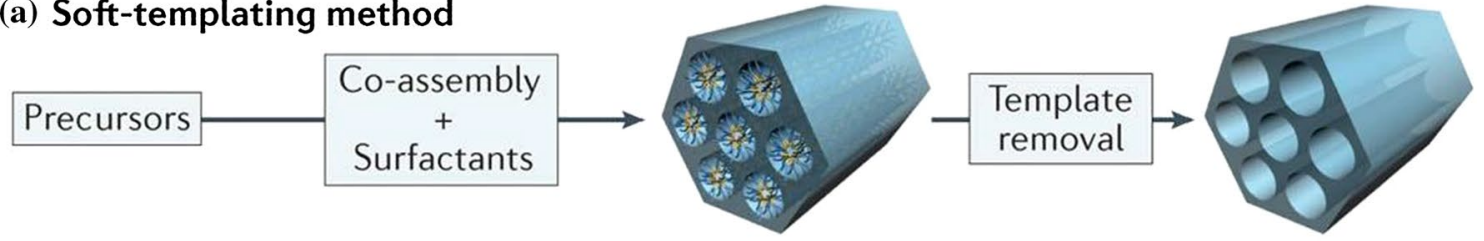

(b) Hard-templating method

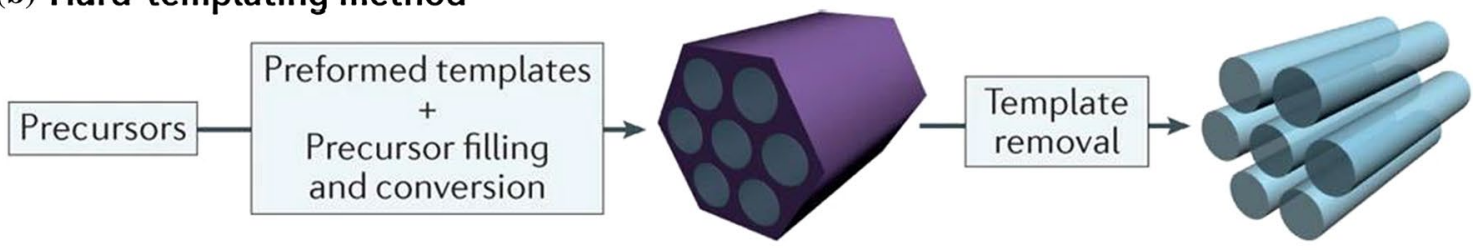

(c) Multiple-templating method

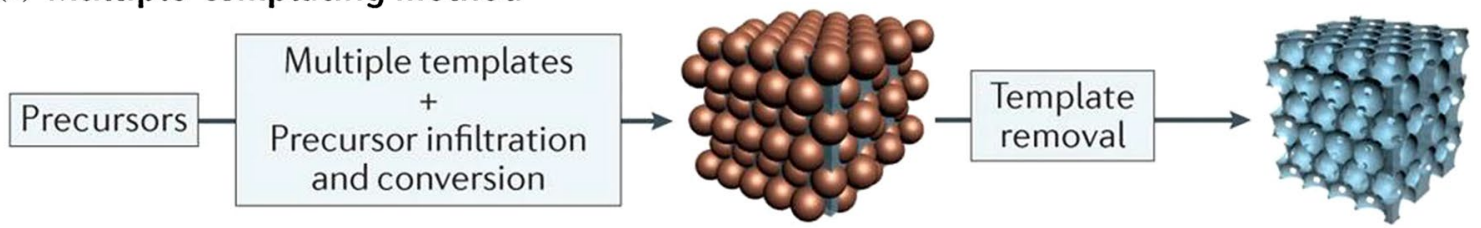

(d) In-situ templating pathway

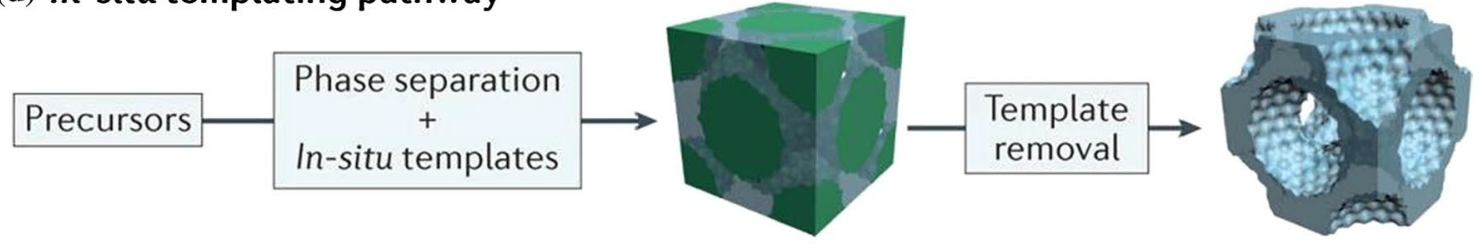

(e) Template-free packing method

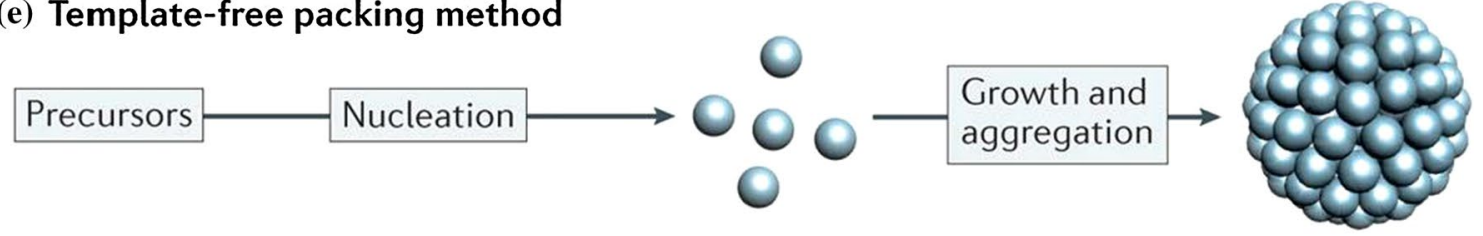

(f) Reticular chemistry guiding approach

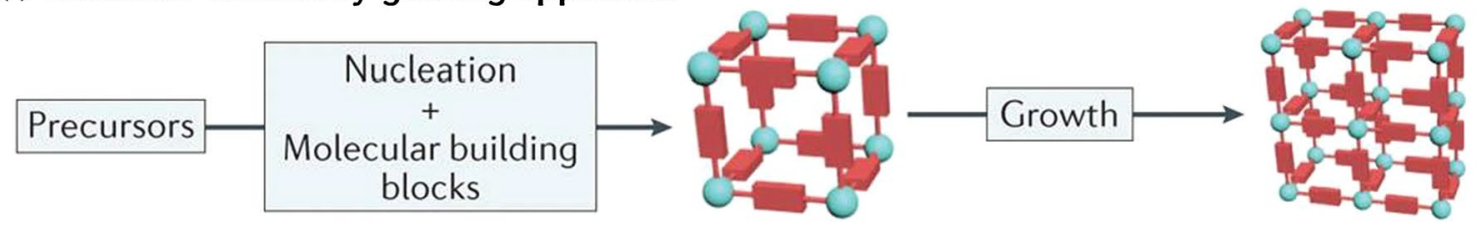

Fig. 18 Mesoporous carbonaceous materials derived from various routes. Interestingly, mesoporous inorganic substances can reproduce their internal structures in nanoporous carbon construction with promising distributed mesoporosity. The nanocasting techniques for

porous ternary nanohybrid based on $\mathrm{NiMn}_{2} \mathrm{O}_{4}$, reduced Graphene oxide, and Polyaniline as an excellent supercapacitor electrode material. The $\mathrm{NiMn}_{2} \mathrm{O}_{4} /$ reduced graphene oxide/ polyaniline shows a specific capacitance of $757 \mathrm{~F} \mathrm{~g}^{-1}$ at $1 \mathrm{~A} \mathrm{~g}^{-1}$. Further, the electrode presented the highest energy density of $\left(70 \mathrm{~W} \mathrm{~h} \mathrm{~kg}^{-1}\right)$ with retained about $93 \%$ after 2000 cycles (Fig. 22). creating mesoporous carbons involved two advanced procedures, the hard and soft templating approaches. Adapted with permission from Ref. Li et al. (2016d). Copyright 2016 Springer Nature

Mariappan et al. (2019) have synthesized ternary hybrid nanocomposites with varying weight portions of reduced graphene oxide/polypyrrole/Co ferrite and reduced graphene oxide/polypyrrole $/ \mathrm{Fe}_{3} \mathrm{O}_{4}$ by a hydrothermal procedure (Fig. 23). The specific capacitance for $37 \mathrm{wt} \%$ reduced graphene oxide $/ 58 \mathrm{wt} \%$ Polypyrrole/5 wt $\% \mathrm{Fe}_{3} \mathrm{O}_{4}$ (FO5), $32 \mathrm{wt} \%$ reduced 


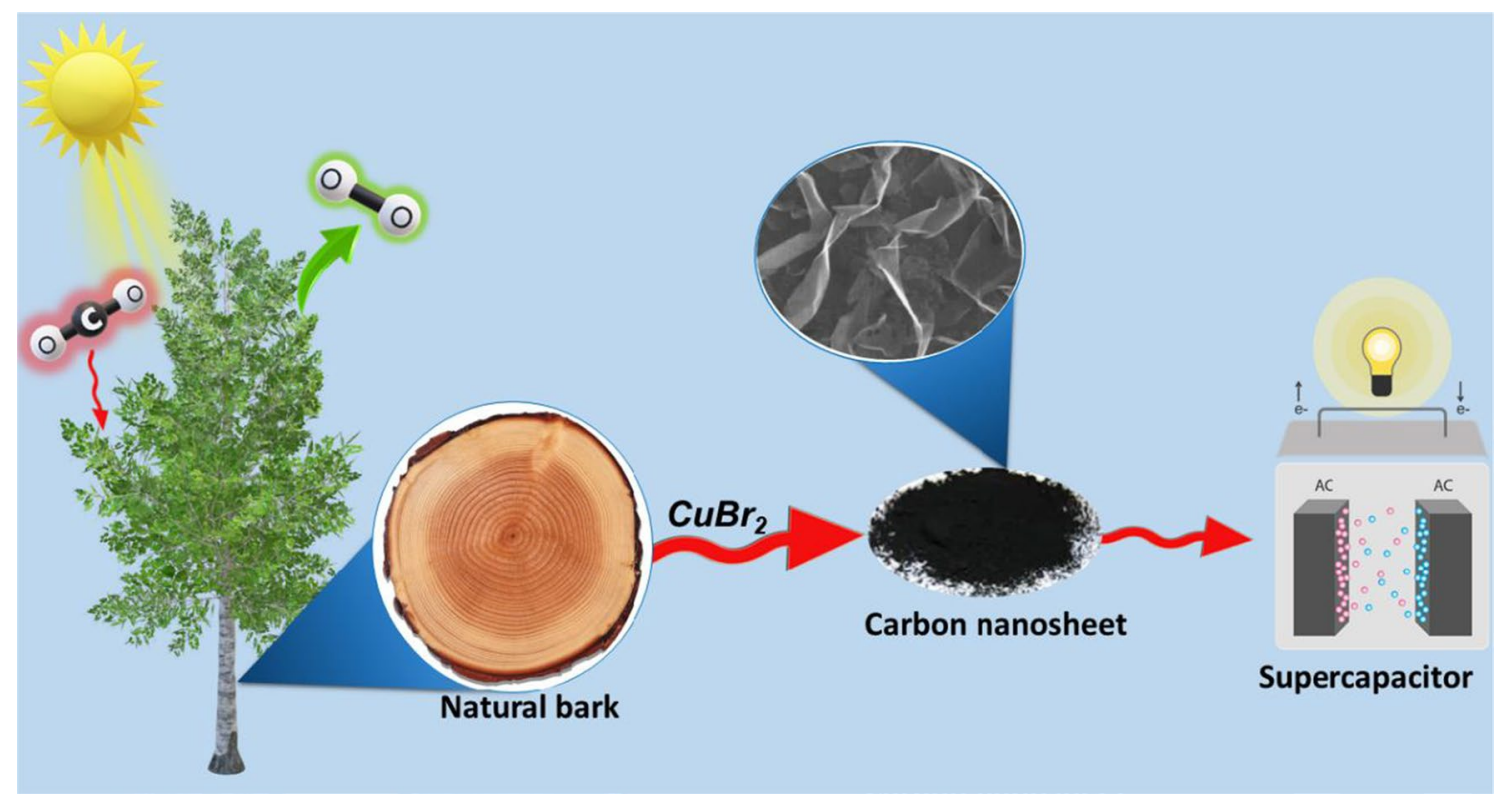

Fig. 19 Preparation of 3D porous carbon nanosheet. The universal method of preparing a carbon nanosheet from bark, which exists in a tree's construction is considered as environmentally friendly. Adapted with permission from Li et al. (2019e) Copyright $(\odot)$ 2019, American Chemical Society

compared with pure graphene. For example, the spin density and charge arrangement of $\mathrm{C}$ atoms will be effected via the neighbor nitrogen substituents, which produces the activation region on the graphene surface (Wang et al. 2012). Chen et al. (2013) have synthesized N-doped graphene hydrogel via the hydrothermal approach. The fabricated electrode exhibited extraordinary power density of $205 \mathrm{~kW} \mathrm{~kg}^{-1}$ and retained about $92.5 \%$ capacitance after 4000 cycles at100 $\mathrm{A} \mathrm{g}^{-1}$. Recently, Rezanezhad et al. (2020) have synthesized the $\mathrm{Mn}-\mathrm{Nd}$ co-doped $\mathrm{LaFeO}_{3}$ perovskite NPs via the hydrothermal technique (Fig. 25). Subsequently, the system was incorporated with $\mathrm{N}$-Graphene oxide nanosheets. The $\mathrm{La}_{0.8} \mathrm{Nd}_{0.2} \mathrm{Fe}_{0.8} \mathrm{Mn}_{0.2} \mathrm{O}_{3}$ sample shows a higher specific capacitance of $158 \mathrm{~F} \mathrm{~g}^{-1}$. Also, it was observed that the incorporation of N-Graphene oxide mainly improves the specific capacitance of the nanocomposite to increase up to $1060 \mathrm{~F} \mathrm{~g} \mathrm{~g}^{-1}$. Additionally, the composite exhibited exceptional capacity retention as $92.4 \%$ after 10,000 cycles which higher than of those for the $\mathrm{La}_{0.8} \mathrm{Nd}_{0.2} \mathrm{Fe}_{0.8} \mathrm{Mn}_{0.2} \mathrm{O}_{3}$ sample (85.37\%).

$\mathrm{Xu}$ et al. (2019c) have synthesized a NiS/MoS $@$ Nreduced graphene oxide composite through the hydrothermal approach. The NiS/MoS $\mathrm{M}_{2} @ \mathrm{~N}$-reduced graphene oxide hybrid is employed as an electrode exhibiting an extraordinary specific capacity $\left(2225 \mathrm{~F} \mathrm{~g}^{-1}\right.$; at $\left.1 \mathrm{~A} \mathrm{~g}^{-1}\right)$, and a high rate of $1347.3 \mathrm{~F} \mathrm{~g}^{-1}$ at $10 \mathrm{~A} \mathrm{~g}^{-1}$. Also, the NiS/MoS $@ \mathrm{~N}$ reduced graphene oxide demonstrates unique capacitive property reached $1028 \mathrm{~F} \mathrm{~g}^{-1}$ at $1 \mathrm{~A} \mathrm{~g}^{-1}$. Further, it gives high energy density up to $35.69 \mathrm{~W} \mathrm{~h} \mathrm{~kg}^{-1}$ at good power 

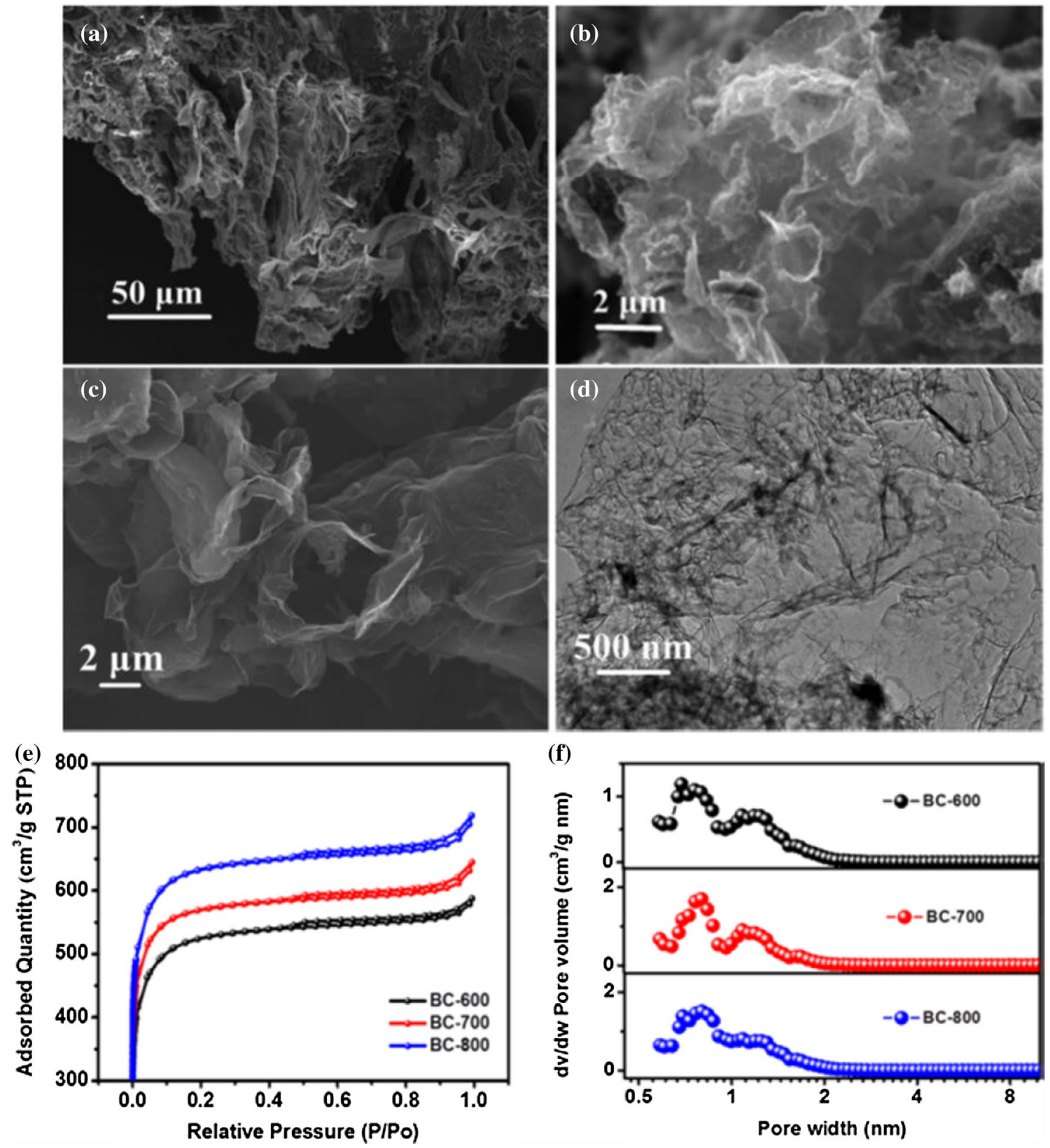

(f)

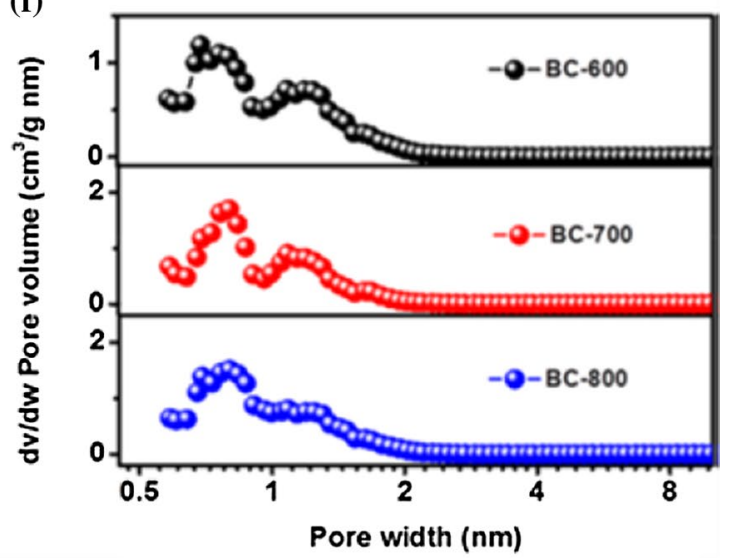

Fig. 20 a-c SEM images of bark, bark-based carbon at $700 \mathrm{C}$, and flower-like carbon, respectively. Which confirm the formation of a typical flower-like carbon structure with outstanding three-dimensional vertical carbon structure through the carbon nanosheet and $\mathbf{d}$

TEM image of the bark-based carbon at $700 \mathrm{C}$, e BET curves adsorption/desorption confirm mesoporous nature and $\mathbf{f}$ distribution of pore radius of bark-based carbon. Adapted with permission from Li et al. (2019e) Copyright @ 2019, American Chemical Society

$601.8 \mathrm{~W} \mathrm{~kg}^{-1}$. Besides, it possesses excellent cycle stability where it retained about $94.5 \%$ from its original capacitance 50,000 cycles (Fig. 26).

\section{Conducting polymers}

Conducting polymer hydrogels have been extensively-utilized in the field of energy storage as supercapacitors owing to many promising and useful attributes like wonderful electrochemical activities, good electrical conductivity, distinctive solid-liquid interface, high stretchability, unique elastic resilience and good energy and power densities ( $\mathrm{Li}$ et al. 2018; Xu et al. 2020; Ma et al. 2019b; Qin et al. 2017; Wang 
Fig. 21 a Cyclic voltammetry and $\mathbf{b}$ the galvanostatic charge/ discharge curves of bark-based carbon versus current densities. $\mathbf{c}$ capacitances and $\mathbf{d}$ Nyquist plots of bark-based carbon samples. The results indicated that bark-based carbon (at 700 ${ }^{\circ} \mathrm{C}$ ) displays an exceptional capacitance comparing to those obtained of bark-based carbon $\left(\right.$ at $\left.600 \mathrm{C}^{0}\right)$. Adapted with permission from Li et al. (2019e) Copyright (C) 2019, American Chemical Society
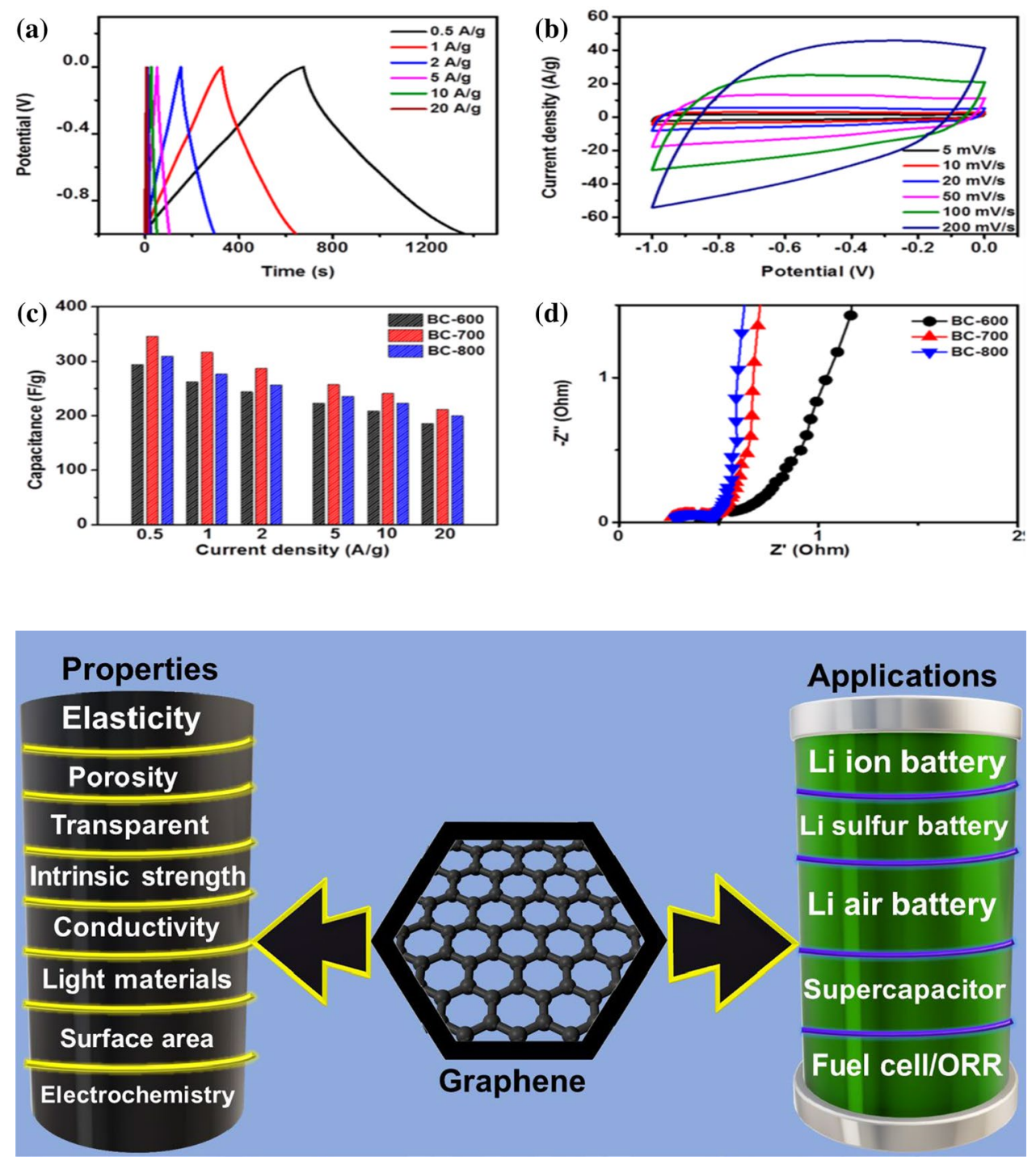

Scheme 1 Graphene material along with their unique properties and various applications. Graphene-derived materials possess a monumental potential for applications in broad areas such as conversion, electronics, energy storage and catalysis (Mahmood et al. 2014)

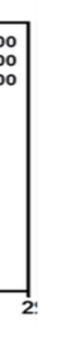




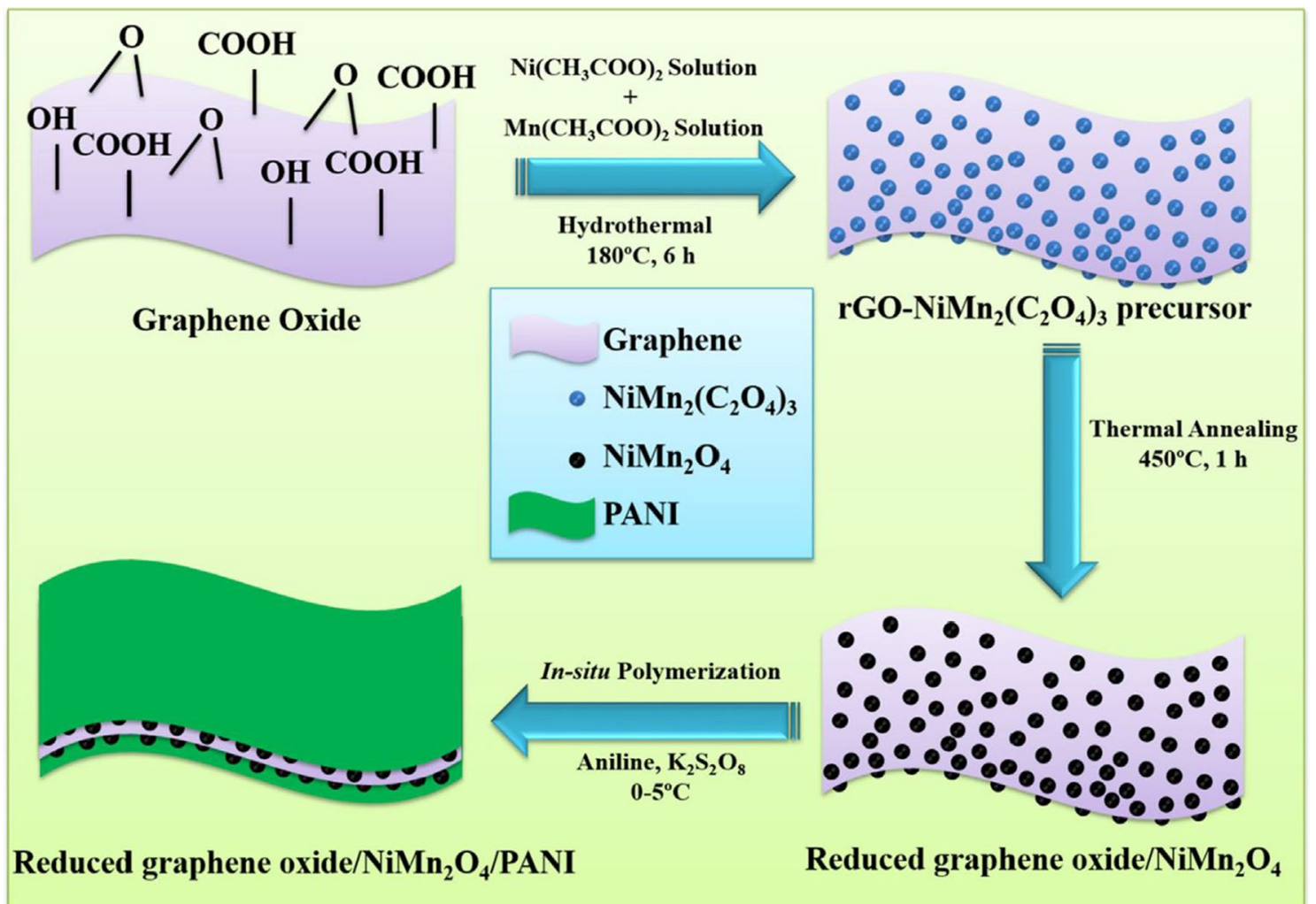

Fig. 22 Preparation of $\mathrm{NiMn}_{2} \mathrm{O}_{4} /$ reduced graphene oxide/polyaniline displays the synthesis mechanism of the ternary nanocomposite. Originally, the hydrothermal conditions induced the formation of $\mathrm{NiMn}_{2} \mathrm{O}_{4}$ on the surface of graphene. Lastly, an in situ polymeri-

capacitance reduction, high energy density $\left(25.8 \mathrm{~W} \mathrm{~h} \mathrm{~kg}^{-1}\right.$ at $901.7 \mathrm{~W} \mathrm{~kg}^{-1}$ power density), unique cycling stability of $90.3 \%$ at $3 \mathrm{~A} \mathrm{~g} \mathrm{~g}^{-1}$ after 6000 cycles and a high voltage window of $1.8-2 \mathrm{~V}$ were obtained. The electrochemical characteristics of the prepared $\mathrm{MnO}_{2} @$ polypyrrole flexible supercapacitor, were collected and are shown in Fig. 27.

To achieve further flexibility, Panpan Li et al. reported a macromolecular self-assembly-based method to develop a 3D Polyaniline/graphene hydrogel. The fabricated 3D Hybrid exhibited powerful interconnectivity and improved mechanical properties ( $\mathrm{Li}$ et al. 2018). The suggested device showed high strain (around 40\%) and achieved considerable energy density of $8.80 \mathrm{~mW} \mathrm{~h} \mathrm{~cm}^{-3}$ at $30.77 \mathrm{~mW} \mathrm{~cm}^{-3}$ power density. In addition to that, the proposed supercapacitor could avoid short-circuiting and effectively defeat large structural deformation.

Another comparative study to understand the role of conducting polymers in supercapacitors was carried out by Zichen Xu et al. where four different polymers including Polyaniline, polypyrrole, poly(3,4-ethylene dioxythiophene) and polythiophene were loaded on a composite of zation method was conducted to fabricate Polyaniline on the binary composite. Adapted with permission from Sahoo et al. (2016), Copyright (2016) Elsevier

zin sulfide and reduced graphene oxide as shown in Fig. 28 (Xu et al. 2020). The investigated samples were fabricated via polymerization of the conducting polymers on $\mathrm{ZnS} /$ reduced graphene oxide composite which was prepared by a hydrothermal route. All employed conducting polymers increased the specific capacitance and cyclic stability of the prepared composite. However, their result showed that the $\mathrm{ZnS} /$ reduced graphene oxide/polyaniline composite possessed the highest capacitance activity and cyclic stability. In the two-electrode configuration, the recorded stability and specific capacitances were $76.1 \%$ and $722 \mathrm{~F} \mathrm{~g}^{-1}$ at $1 \mathrm{~A} \mathrm{~g}^{-1}$, respectively after 1000 cycles. While, in the three-electrode system, the obtained specific capacitance and stability were $1045.3 \mathrm{~F} \mathrm{~g}^{-1}$ and $160 \%$ at the same conditions. In addition, the maximum power and energy densities were $18 \mathrm{~kW} \mathrm{~kg}^{-1}$ and $349.7 \mathrm{~W} \mathrm{~h} \mathrm{~kg}^{-1}$. This superior characteristic of the $\mathrm{ZnS} /$ reduced graphene oxide/polyaniline composite was attributed to $\mathrm{N}$ and $\mathrm{S}$ active sites of this composite which fostered electrolyte penetration during cycling and allowed further active sites. 

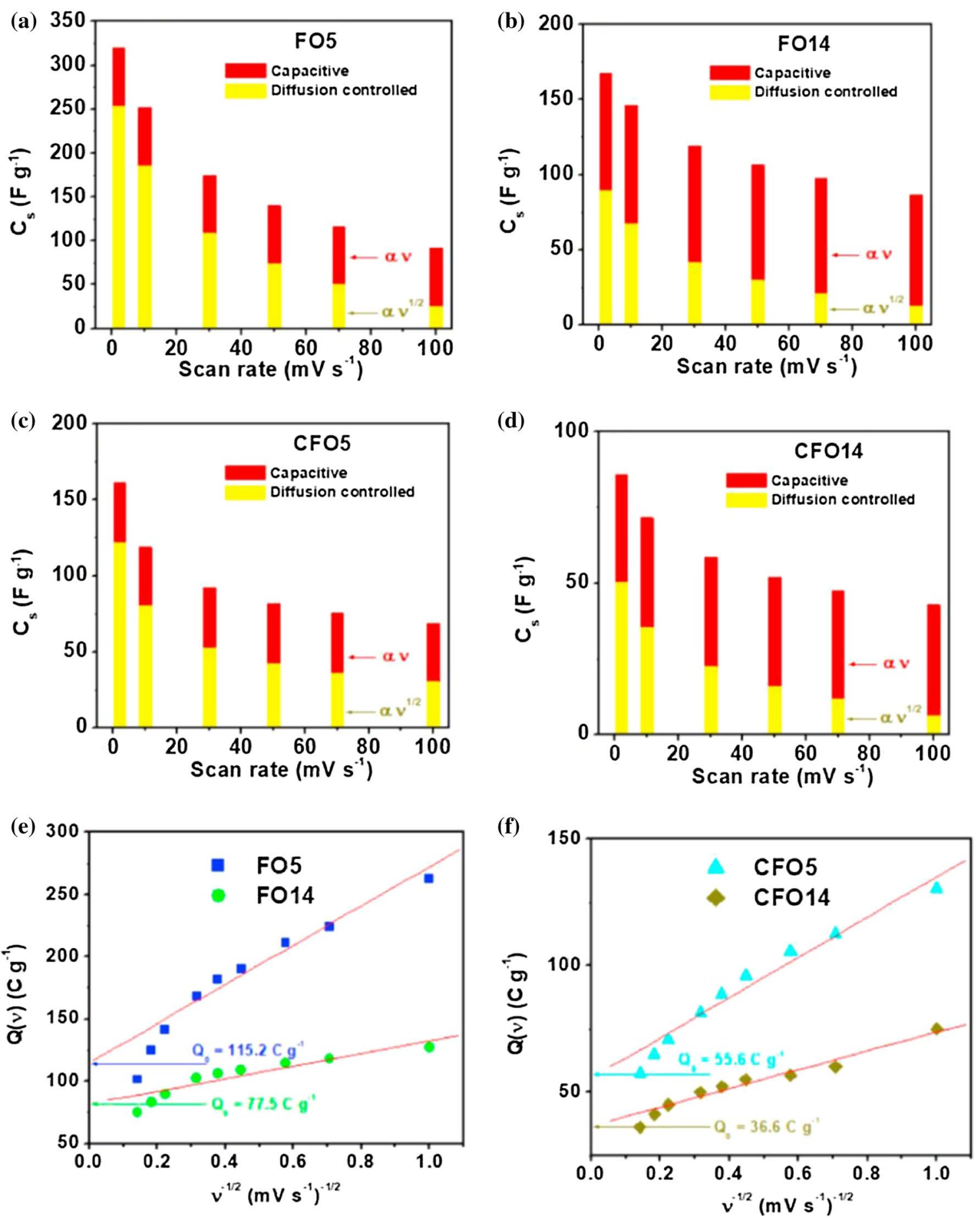

Fig. 23 Capacitive and diffusion measured capacitance parts for synthesized ternary hybrid nanocomposites with varying weight portions of reduced graphene oxide/polypyrrole/Co ferrite and reduced graphene oxide/polypyrrole/ $\mathrm{Fe}_{3} \mathrm{O}_{4}$ a FO5, b FO14, c CFO5, and d

CFO14. e, f Trasatti plot for evaluation the specific capacitance contribution of the external surface of the electrode for all nanocomposites. Adapted with permission from Mariappan et al. (2019), Copyright (2019) Elsevier 


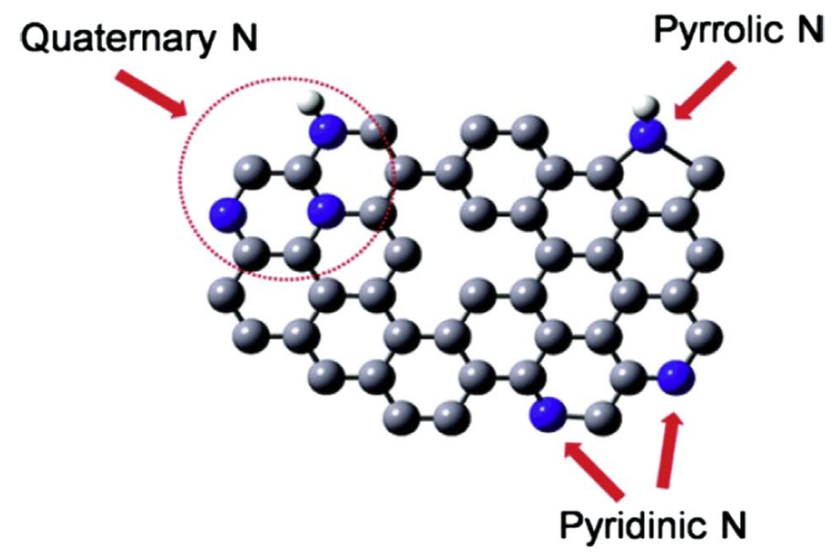

Fig. 24 Bonding configurations types of nitrogen atom doped graphene. During a nitrogen atom is doped into graphene, three public bonding arrangements within the carbon lattice (Yadav and Dixit 2017)

Highly-flexible, conducting polymer-based supercapacitors were fabricated by Qingqing Qin et al. by employing polybenzimidazole of 100 megapascals tensile strength (Qin et al. 2017). In their study, graphite paper-coated activated carbon was integrated with the polybenzimidazole conducting polymer. The obtained device showed low series resistance and very high capacitance retention stability more than $90 \%$ after 10,000 cycles. Besides, the electrochemical performance of the tested supercapacitors remained stable after twisting, bending and rolling; indicating their unique flexibility and mechanical damage-resistant reliability.

Stretchable electrodes are the basis of stretchable supercapacitors. Xi Wang et al. reported the fabrication of stretchable electrodes based on polyaniline or poly(1,5-diaminoanthraquinone) polymers supporting acrylate rubber/multi-wall carbon nanotubes composite (Wang et al. 2018b). The prepared acrylate rubber/multi-wall carbon nanotubes loaded on poly(1,5-diaminoanthraquinone) and acrylate rubber/ multi-wall carbon nanotubes loaded on Polyaniline exhibited a large volumetric capacitance at $1 \mathrm{~mA} \mathrm{~cm}^{-2}$ of about $20.2 \mathrm{~F} \mathrm{~cm}^{-3}$ and $17.2 \mathrm{~F} \mathrm{~cm}^{-3}$, respectively, as shown in Fig. 29. The unique energy density of about $2.14 \mathrm{~mW} \mathrm{~h} \mathrm{~cm}^{-3}$ was obtained after assembling asymmetrical supercapacitor by employing poly(1,5-diaminoanthraquinone)-loaded acrylate rubber/multi-wall carbon nanotubes as the anode and polyaniline-loaded acrylate rubber/multi-wall carbon nanotubes as the cathode. Moreover, capacitance retention of $86 \%$ at $30 \mathrm{~mA} \mathrm{~cm}^{-2}$ and good cycling stability after harsh strain conditions were achieved.

Carbon nanotubes have allowed the uniform distribution of conducting polymers without any need of binding compounds or linkers. Besides, they possess excellent conducting and mechanical properties. Frackowiak et al. (2006), reported the fabrication of three different composites made of multiwall carbon nanotubes, polyaniline, polypyrrole and poly(3,4-ethylene dioxythiophene) conducting polymers. The prepared composites exhibited both pseudo-capacitance and electrostatic attraction. The employed multiwall carbon nanotubes allowed good mechanical properties and preserved the active materials of the tested conducting polymers from mechanical deformation during long cycling measurements. A range of capacitance values from 100 to $330 \mathrm{~F} \mathrm{~g}^{-1}$ was obtained at capacitance voltage $0.6-1.8 \mathrm{~V}$ using various asymmetric configurations. This unique performance was attributed to the presence of multiwall carbon nanotubes which allowed high charge/discharge rates through an enhanced charge transfer.

A similar study was conducted by employing reduced graphene oxide sheets. Jintao Zhang et al. reported the in situ polymerization of poly(3,4-ethylene dioxythiophene), polyaniline, and polypyrrole on the surface of reduced graphene oxide (Zhang and Zhao 2012). Due to the synergic effect of conducting polymers and reduced graphene oxide sheets. The prepared nanocomposites displaced above $80 \%$ retained capacitance after 1000 cycles. In addition, reduced graphene oxide@ polyaniline composite showed $361 \mathrm{~F} \mathrm{~g}^{-1}$ specific capacitance at $0.3 \mathrm{~A} \mathrm{~g}^{-1}$ current density. While specific capacitances of $248 \mathrm{~F} \mathrm{~g} \mathrm{~g}^{-1}$ and $108 \mathrm{~F} \mathrm{~g} \mathrm{~g}^{-1}$ were recoded for reduced graphene oxide-polypyrrole and reduced graphene oxide@poly(3,4-ethylene dioxythiophene) composites, respectively, as shown in Fig. 30.

Based on the electrostatic attraction between surfactants of positive charge and negatively-charged graphene oxide sheets, Zhang et al. reported a simple and cost-effective method for the preparation of graphene oxide@polypyrrole sandwich structure (Zhang et al. 2010). The prepared composite showed a unique performance with a capacitance of $500 \mathrm{~F} \mathrm{~g}^{-1}$. High cyclic stability was also achieved. The reported properties were attributed to many factors including, exfoliated graphene oxide which enabled many active sites for both sides' conjugation of polypyrrole, the prepared 3D structure enabled cyclic stability, resistance reduction by graphene oxide and polypyrrole which effectively-contributed to the overall capacitance.

Similarly, Wang et al. (2005) used the electrochemical route for synthesizing carbon nanotubes@ polypyrrole composite. The composite was prepared via polypyrrole plating into the host membrane's pores. High conductivity (I-V relation) and stability were obtained as shown in Fig. 31.

Another configuration based on poly ( $N$-phenylglycine) conducting polymer was reported by Vedi Kuyil et al. which was synthesized via in situ polymerization and $N$-phenylglycine's electrodeposition on exfoliated graphite sheets (Muniraj et al. 2020). The electrochemical performance of the investigated device showed a unique specific capacitance 


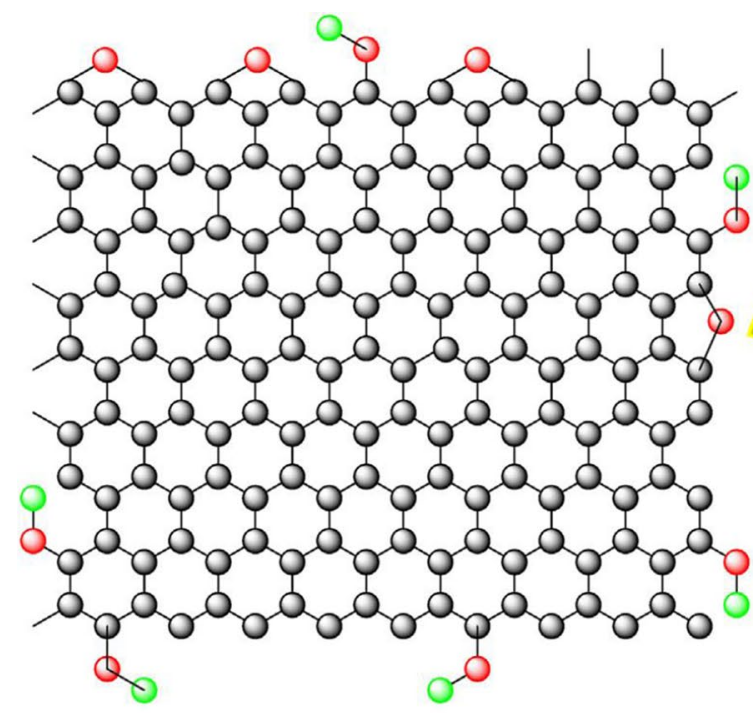

\section{GO}
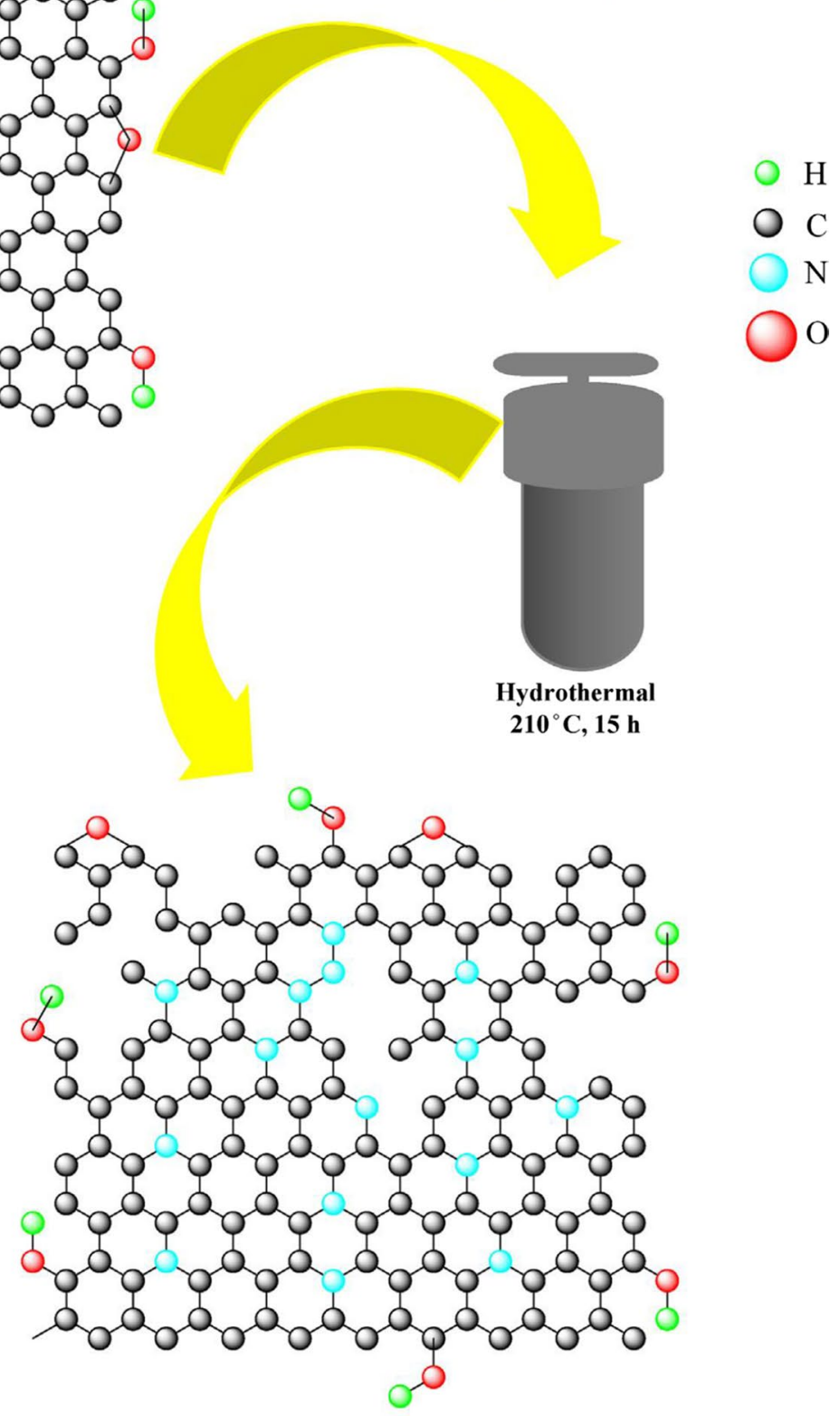

NGO

Fig. 25 Fabrication of N-graphene oxide from graphene oxide by hydrothermal technique. Adapted with permission from Rezanezhad et al. (2020) Copyright (2020) Elsevier

at $10 \mathrm{mV} \mathrm{s}^{-1}$ of $367 \mathrm{mF} \mathrm{cm}^{-2}$. Interestingly, an outstanding $8.36 \mu \mathrm{W} \mathrm{h} \mathrm{cm}{ }^{-2}$ energy was recorded at $1.65 \mathrm{~mW} \mathrm{~cm}^{-2}$ power density using $1.1 \mathrm{~V}$ potential window.
Dirican et al. (2020) reported electrodeposition and electrospinning-based method for the fabrication of Polyaniline@ $\mathrm{MnO}_{2} @$ porous carbon nanofibers for supercapacitors. 

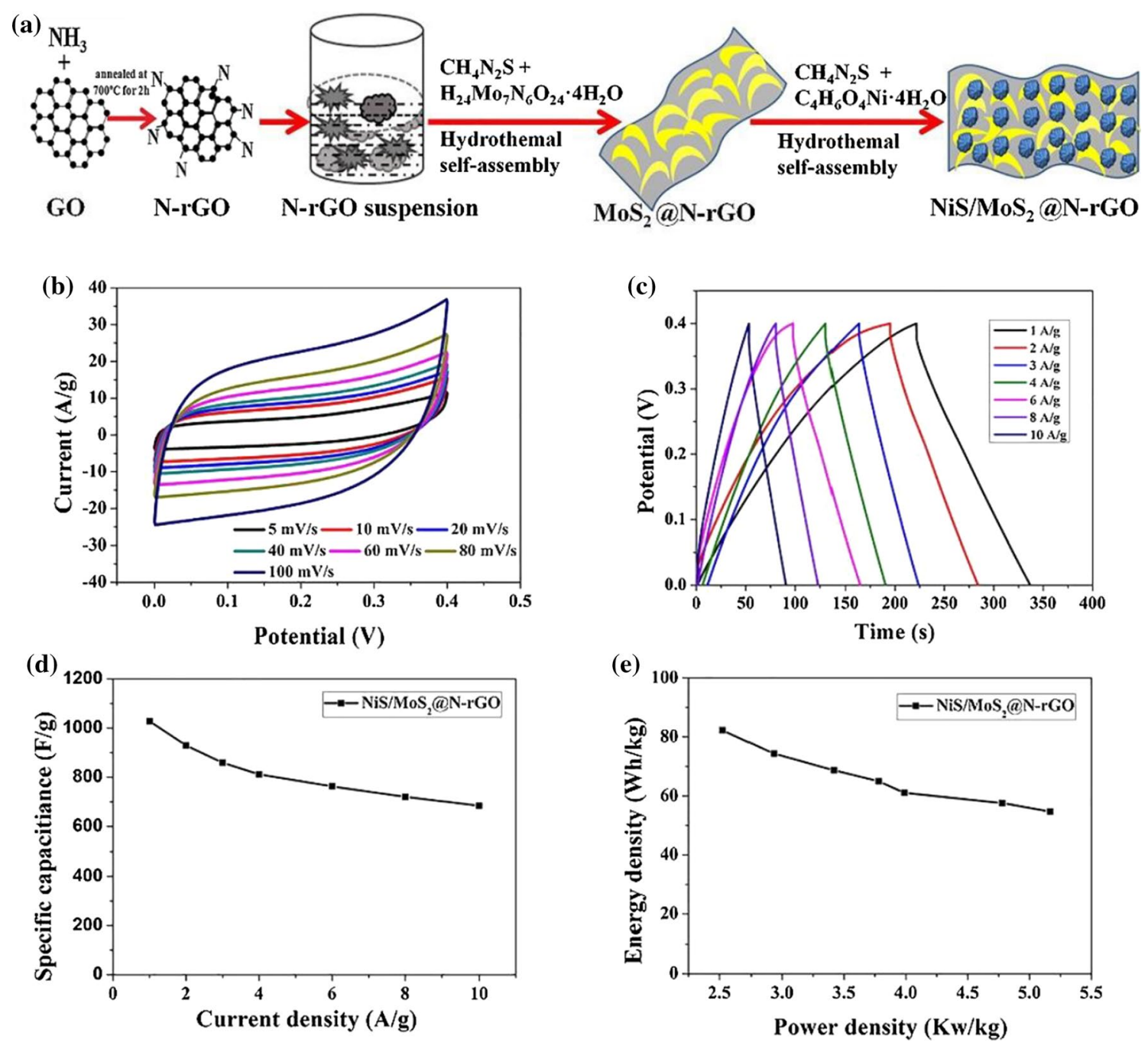

Fig. 26 a 3 Dimensional $\mathrm{NiS} / \mathrm{MoS}_{2} @ \mathrm{~N}$-reduced graphene oxide composites schematic fabrication, $\mathbf{b}$ cyclic voltammetry curves versus scan rates. c The galvanostatic charge/discharge curves versus current

densities. d Capacitances versus current densities. e Plots of Ragone. Adapted with permission from Xu et al. (2019c), Copyright (2019) Elsevier

The proposed device combined the advantages of porous carbon nanofibers good cyclic stability, large conductivity of Polyaniline and $\mathrm{MnO}_{2}$ nanoparticles' high pseudocapacitance. As a result, the prepared device exhibited high capacitance of about $289 \mathrm{~F} \mathrm{~g}^{-1}$ and large retained capacitance of 91\% after 1000 cycles as shown in Fig. 32. Besides, the configuration of the asymmetrical cell showed an enhanced energy density of $119 \mathrm{~W} \mathrm{~h} \mathrm{~kg}^{-1}$ and $322 \mathrm{~W} \mathrm{~kg}^{-1}$ power density.

Recent studies on polymer-based supercapacitors are summarized in Table 3.

\section{Bibliometric analysis}

Prior to the bibliometric analysis, preliminary Web of Science results showed there were only two publications in the last three years using the search criteria of TOPIC: ("supercapacitor") AND TOPIC: ("transition metal") AND TOPIC: (spinel ferrites) Timespan: Last 5 years. Indexes: SCI-EXPANDED, SSCI, A\&HCI, CPCI-S, CPCI-SSH, ESCI. Additionally, the document types are research articles, this indicates that there is a significant gap in the literature regarding spinel ferrites and transition metal ions (oxide or sulfide). On the other hand, using the search criteria (TOPIC: ("supercapacitor") AND TOPIC: ("conducting polymer") over a similar time frame indicated 364 results for the conducting polymers, this clearly shows there is an 

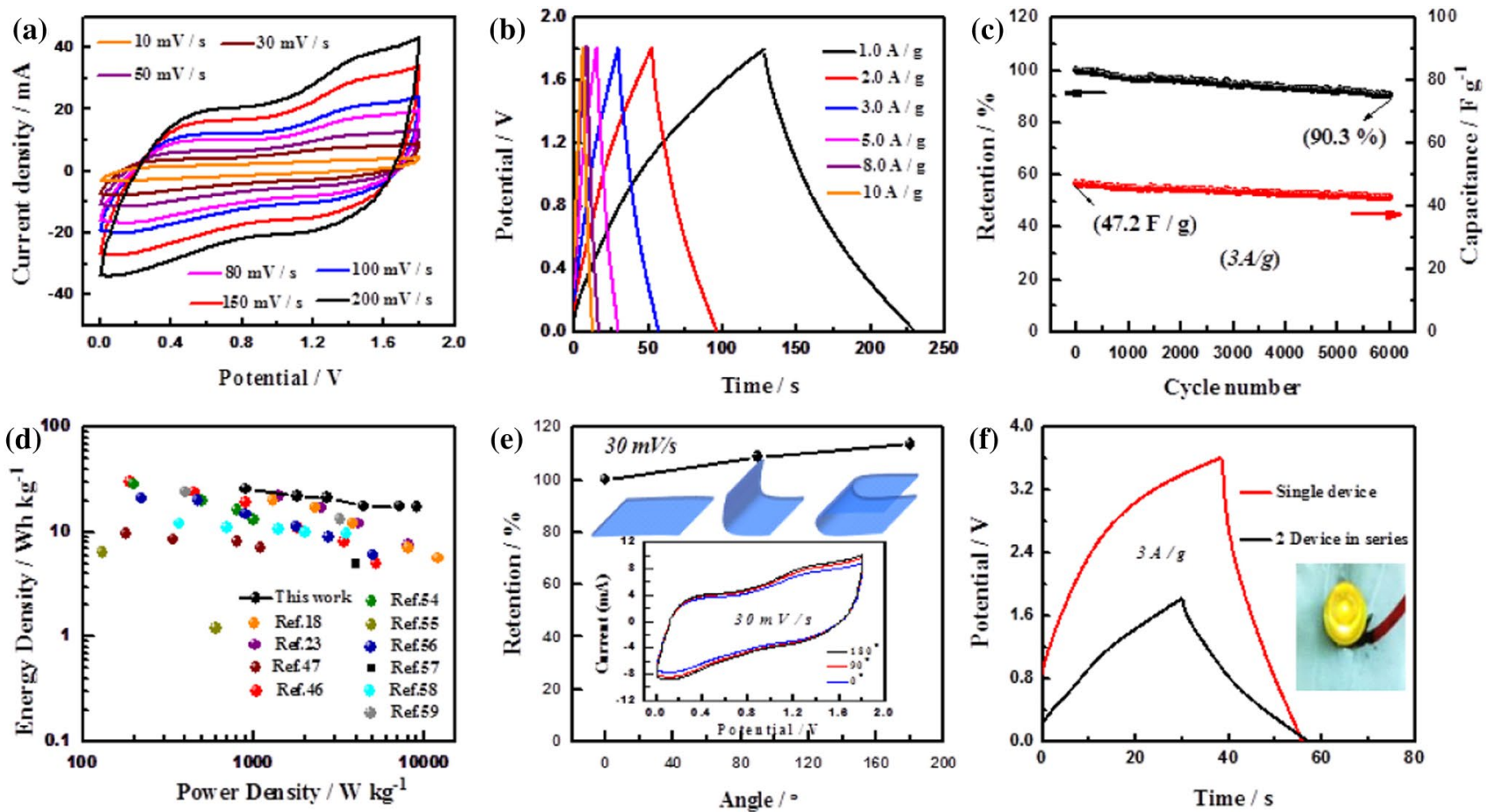

Fig. 27 a Cyclic voltammetry curves versus scan rates, b the galvanostatic charge/discharge versus current densities, c cycling stability, d Ragone plot, $\mathbf{e}$ cycling activity at various bending and $\mathbf{f}$ single and

abundant amount of research regarding conducting polymers as supercapacitors. Among the results, there are 323 research articles along with 28 review articles.

The bibliometric mapping of supercapacitors over the last 5 years showed 964 results using the search criteria (from Web of Science Core Collection) "TOPIC: (supercapacitor transition metal) OR "supercapacitor" over the last 5 years. Again, as seen in Fig. 33 most of the research outputs are conducting polymers and graphene in the energy storage field. Another identified cluster (shown in green) is the growing field of composite materials used as supercapacitors. As seen in the density visualization map (Fig. 34), derived from bibliometric results, there are prominent keywords that dominate the existing research. These include but not limited to graphene, nanostructure and $\mathrm{Ni}$ foam. Interestingly, composites fall slightly outside the dense region.

\section{Conclusion}

Supercapacitors were employed for normal applications like memory protection and internal battery backup. However, in recent years, the application area has widened significantly double supercapacitor the galvanostatic charge/discharge of prepared $\mathrm{MnO}_{2} @$ polypyrrole. Adapted with permission from He et al. (2017), Copyright 2017, Elsevier

toward hybrid carriers, smartphones, and energy collection. The latest technologies on the horizon encourage making and placing supercapacitors into direct competition with rechargeable batteries.

In this review, we selected various electrode materials such as spinel ferrites, perovskite oxides, transition metals sulfides, carbon materials, and conducting polymer materials and evaluated their performance and outlined their advantages and disadvantages in the application of supercapacitors. The current review highlights the available literature documented on the electrochemical activities of nanostructured of selected materials, their composites, and possible approaches to implementing these materials in $\mathrm{Li}$-ion batteries in the soon future.

The spinel ferrite and perovskite oxides based materials present notable discharge capacities of $1000 \mathrm{~mA} \mathrm{~h} \mathrm{~g}^{-1}$, which is two to three times higher than that those obtained via graphite anodes (Yuvaraj et al. 2016; Yin et al. 2013). In magnetic oxides and through the initial discharging cycle, the crystal structure is destructed into different mineral particles following with the production of the $\mathrm{Li}_{2} \mathrm{O}$ form. As performed mineral particles promote the electrochemical action using the production/destruction of $\mathrm{Li}_{2} \mathrm{O}$ that supplies 


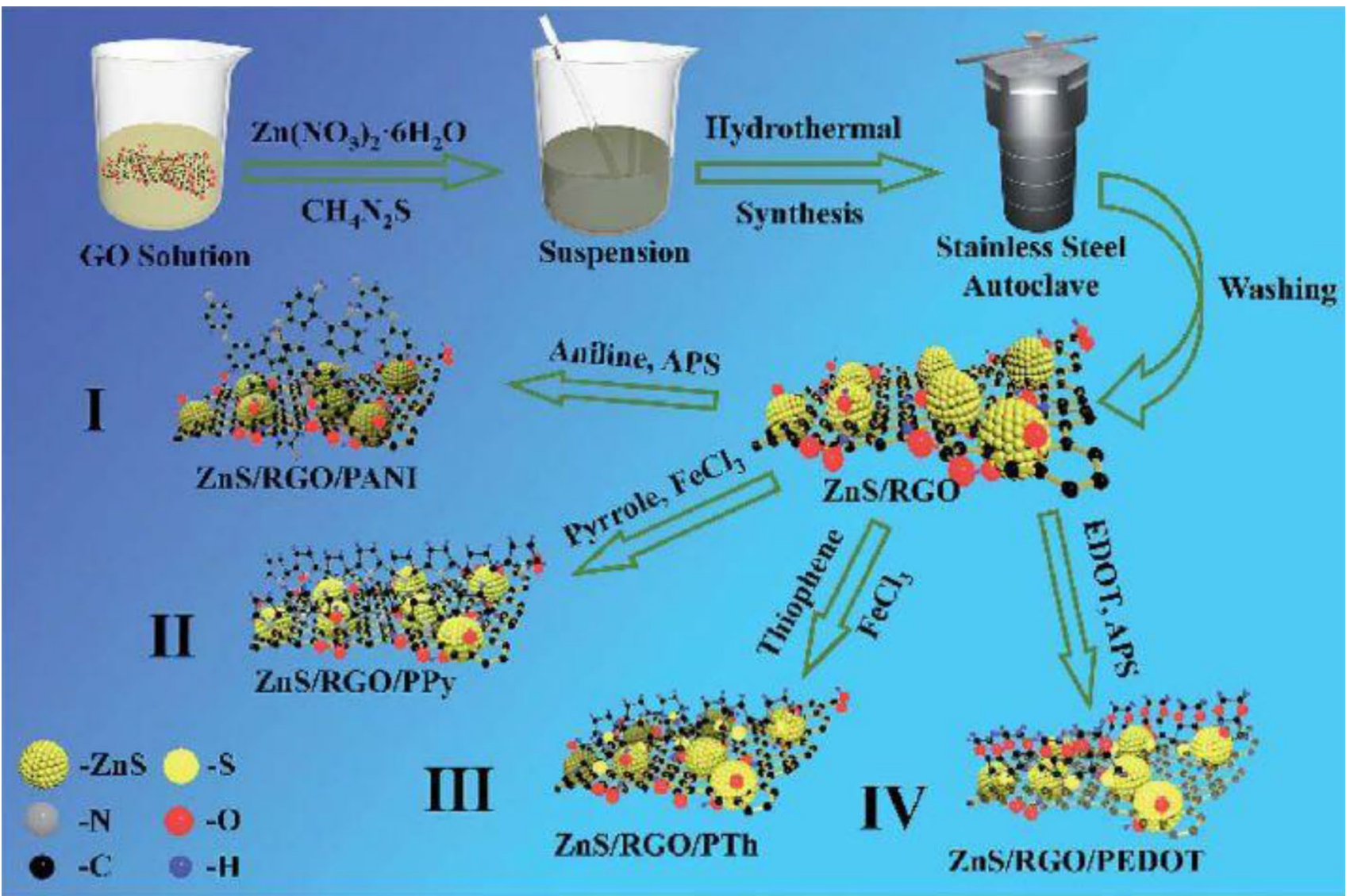

Fig. 28 Synthesis of conducting polymers-loaded onto $\mathrm{ZnS} /$ reduced graphene oxide composite. The amount of $\mathrm{ZnS} /$ reduced graphene oxide was dispersed in deionized water. The solution of acetonitrile

the route for the conversion reaction mechanism. The magnetic oxides have many crystals whose shapes depend upon, the synthesizing technique, and temperature of the annealing process. Besides, their specific capacitance and better cycling stability are dependent on the crystals' shape (Ajay et al. 2015). Also, the replacement of multiple cations into the A- or B-sites can change the symmetry of the pristine structure and consequently, the physical and chemical properties (Zhang et al. 2016c). The magnetic oxides (spinel ferrites and perovskite oxides) as anodes holds an edge for supercapacitors and hybrid supercapacitors (Liu et al. 2018c). Hence, the immense content of oxygen vacancies $\left(\mathrm{O}_{\text {vacancy }}\right)$, and remarkable conductivity allow their extraordinary energy densities. Also, the perovskites store charge by oxygen intercalation and the excellent diffusion pathways along crystal domain boundaries leading the promotion of the dispersion rate (Nan et al. 2019). However, the transition dropwise in 3, 4-ethylenedioxythiophene in the presence of ammonium persulfate and stirred in an ice bath. Adapted with permission from Xu et al. (2020), Copyright 2020, Royal Society of chemistry

metal sulfides are promising materials for energy storage applications because of their excellent electrochemical characteristics. The electrochemical characteristics of transition metal sulfides are much better than that of transition metal oxides; this is can be explained by the presence of sulfur atoms instead of oxygen atoms. Hence, the lower electronegativity of sulfur than that of oxygen facilitates electron transfer in the metal sulfide structure easier than that in the metal oxide form. Thus, replacing oxygen with sulfur, provides more flexibility for nanomaterials synthesis and fabrication (Jiang et al. 2016).

However, the lower conductivity, low cycling stability and volume change during charge/discharge cycles of metals oxides and transition metal sulfides make them insufficient materials for performing supercapacitors. To defeat those disadvantages, the conducting polymers or conducting materials were added to the magnetic oxides or transition 


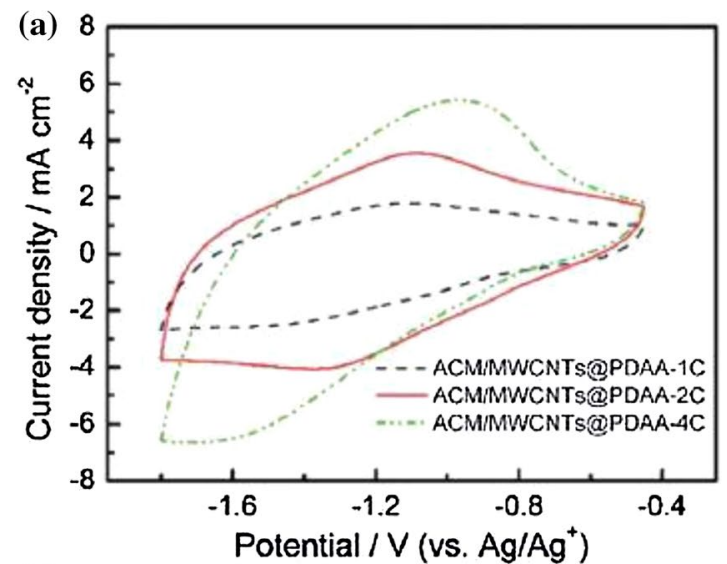

(c)

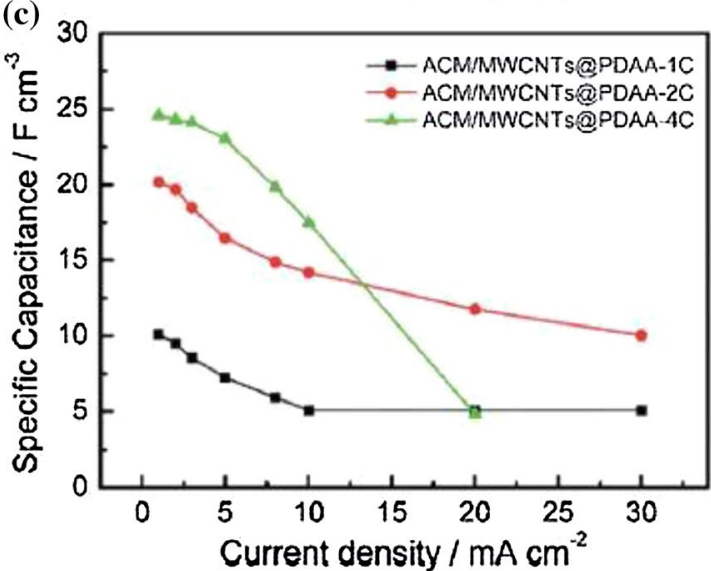

Fig. 29 a Cyclic voltammetry curves measured at $10 \mathrm{mV} \mathrm{s}^{-1}$, b the galvanostatic charge/discharge curves, $\mathbf{c}$ capacitance vs current density and $\mathbf{d}$ capacitance versus cycle number of the fabricated acrylate

metal sulfides to amplify the electronic conductivity and to enhance the cycling stability (Yang et al. 2018; Qiao et al. 2018). Conducting polymer hydrogels have been extensively used in the field of energy storage for supercapacitors production owing to many promising and outstanding properties like powerful electrochemical activities, improved electrical conductivity, distinctive solid-liquid interface, high stretchability, unique elastic resilience and good power and energy densities (Li et al. 2018; Xu et al. 2020; Ma et al. 2019b; Qin et al. 2017; Wang et al. 2018b, 2019c). Also, graphene has received great attention in research owing to its extraordinary features, such as high conductivity, powerful mechanical strength, large specific area, porosity, and electrochemically active nature. The result showed that the composites that comprise of magnetic oxides or transition metal sulfides with conducting polymers or conducting materials possessed

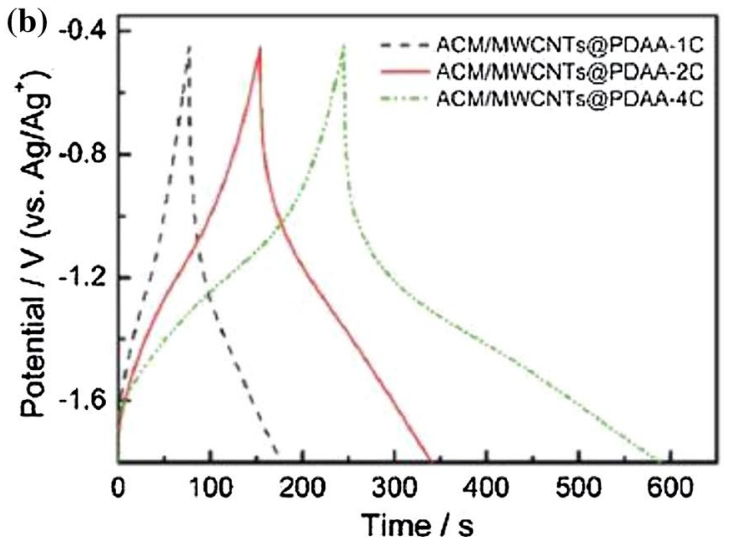

(d)

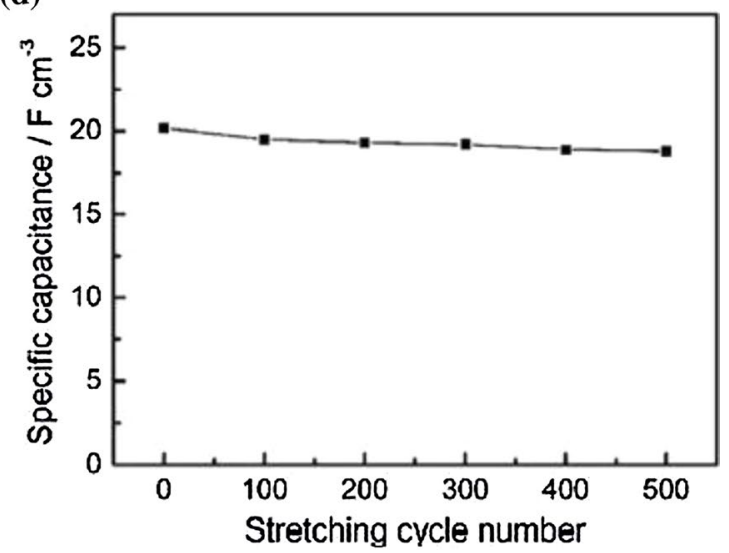

rubber/multi-wall carbon nanotubes/poly (1,5-diaminoanthraquinone). Adapted with permission from Ref. Wang et al. (2018b), Copyright 2018, Royal Society of chemistry

the highest capacitance activity and cyclic stability. These superior characteristics of these composites were attributed to oxygen and $\mathrm{S}$ active sites of this composite which fostered electrolyte penetration during cycling and allowed further active sites (Xu et al. 2020).

In brief, it is deduced that the electrochemical achievement of the magnetic oxides or transition metal sulfides is improved in the following techniques: designed magnetic oxides or transition metal sulfides that have considerable surface areas, possess a huge porosity, composites with carbonaceous materials (core-shells and graphene), and/or conducting polymers, that decrease the irreversible capacity loss and the production of stable supercapacitors. Hence, mixed-magnetic oxides or transition metal sulfides and their composites are the ideal prospective materials for the next generation of energy-storage applications. 

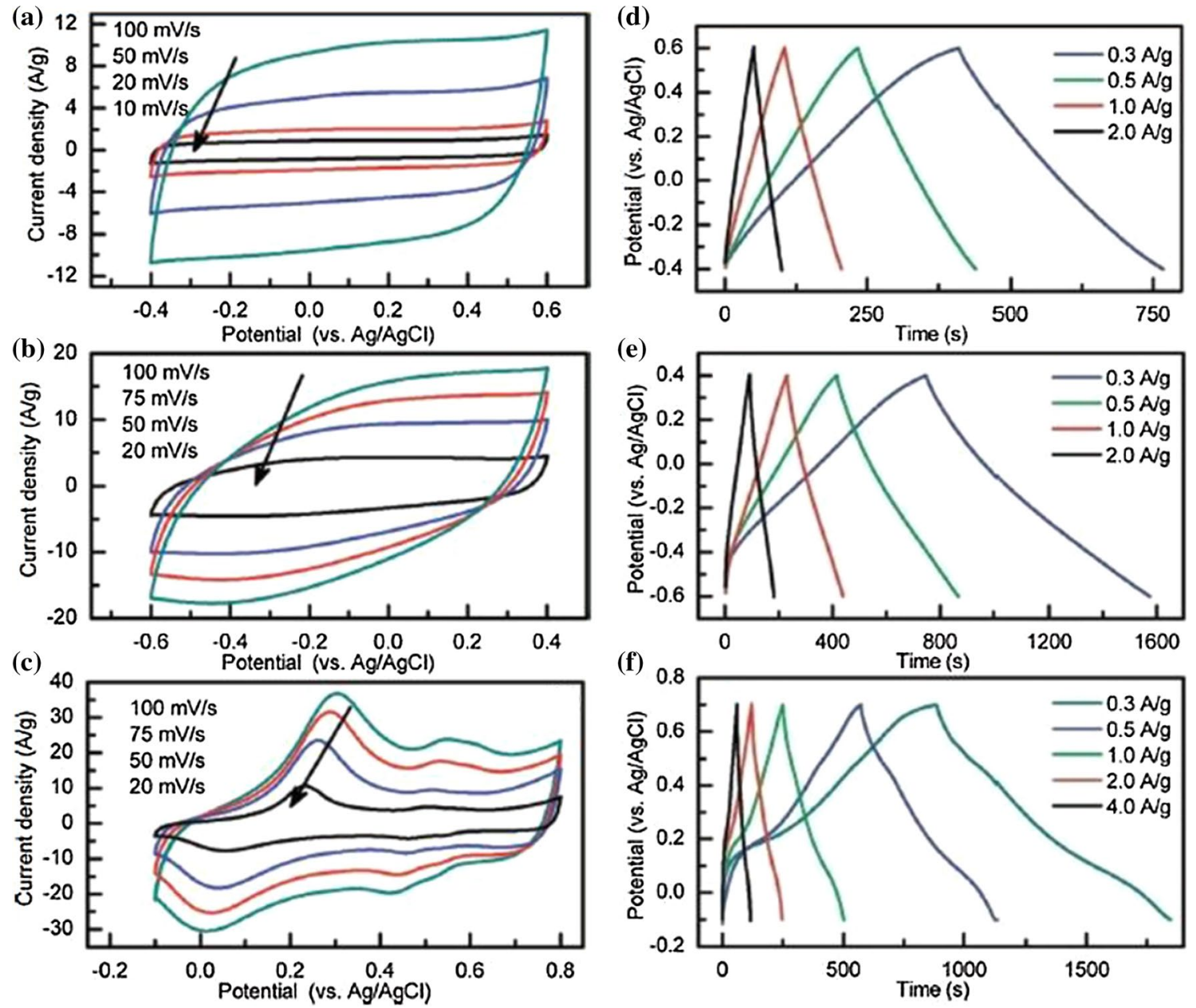

Fig.30 Cyclic voltammograms of a reduced graphene oxide@ poly(3,4-ethylene dioxythiophene) composite, b reduced graphene oxide@polypyrrole composite and c reduced graphene oxide@polyaniline composite, $\mathbf{d}$ charge/discharge pattern of reduced graphene

oxide@poly(3,4-ethylene dioxythiophene) composite, e reduced graphene oxide@polypyrrole composite and f reduced graphene oxide@ polyaniline composite. Adapted with permission from Ref. Zhang and Zhao (2012), Copyright 2012, American Chemical Society

Fig. 31 Cyclic voltammetry curves of a carbon nanotubes and $\mathrm{Cl}^{-}$-doped polypyrrole nanowires b polypyrrole films. Adapted with permission from Ref. Wang et al. (2005), Copyright 2004, American Chemical Society
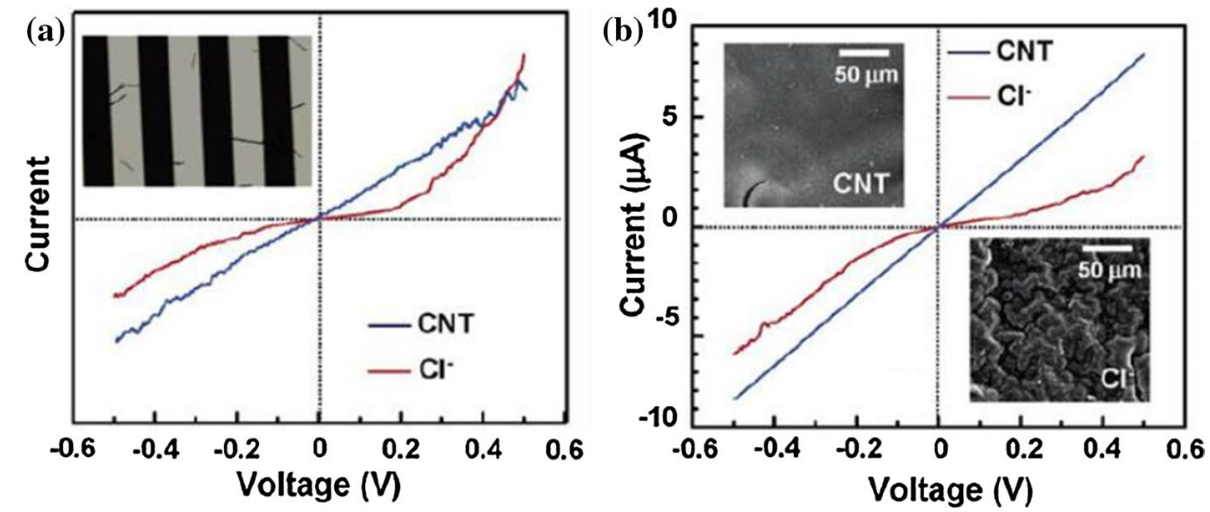

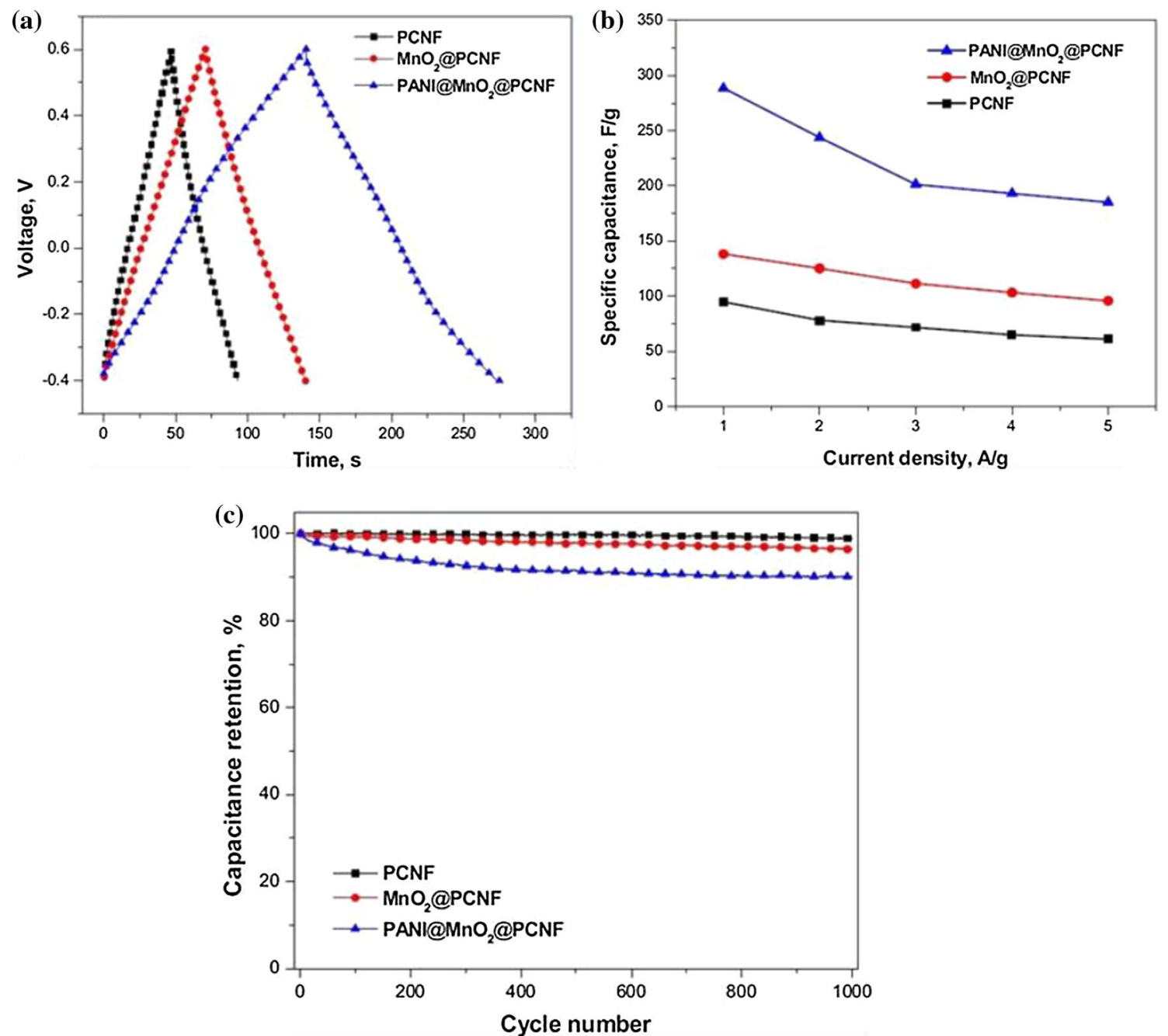

Fig. 32 a Galvanostatic charge/discharge patterns of polyaniline@ $\mathrm{MnO}_{2} @$ porous carbon nanofibers, $\mathrm{MnO}_{2} @$ porous carbon nanofibers and porous carbon nanofibers, $\mathbf{b}$ specific capacitance of porous carbon nanofibers, $\mathrm{MnO}_{2} @ \mathrm{PCNF}$ and Polyaniline@ $\mathrm{MnO}_{2} @$ porous carbon nanofibers and $\mathbf{c}$ retained capacitance of Polyaniline@ $\mathrm{MnO}_{2} @$ porous carbon nanofibers, $\mathrm{MnO}_{2} @$ porous carbon nanofibers and porous carbon nanofibers. The prepared device exhibited high capacitance $\left(289 \mathrm{~F} \mathrm{~g}^{-1}\right)$ and largely retained capacitance. Adapted with permission from Dirican et al. (2020), Copyright 2020, Elsevier 
Table 3 Recent studies on polymer-based supercapacitors

\begin{tabular}{|c|c|c|c|c|c|c|c|}
\hline $\begin{array}{l}\text { Electrode } \\
\text { material }\end{array}$ & Electrolyte & $\begin{array}{l}\text { Current den- } \\
\text { sity }\left(\mathrm{A} \mathrm{g}^{-1}\right)\end{array}$ & $\begin{array}{l}\text { Specific capaci- } \\
\text { tance }\left(\mathrm{F} \mathrm{g}^{-1}\right) / \\
\text { areal capacitance } \\
\left(\mathrm{mF} \mathrm{cm}^{-2}\right)\end{array}$ & $\begin{array}{l}\text { Stability } \\
\% / \text { no. of } \\
\text { cycles }\end{array}$ & $\begin{array}{l}\text { Retained } \\
\text { specific } \\
\text { capaci- } \\
\text { tance \% }\end{array}$ & $\begin{array}{l}\text { Energy density }\left(\mathrm{W} \mathrm{h} \mathrm{kg}^{-1}\right) / \text { power } \\
\text { density }\left(\mathrm{kW} \mathrm{kg}^{-1}\right)\end{array}$ & References \\
\hline $\begin{array}{c}\mathrm{Na}_{x} \mathrm{MnO}_{2} @ \\
\text { carbon } \\
\text { nanotubes }\end{array}$ & $\begin{array}{l}\text { potassium } \\
\text { poly(acrylate)@ } \\
\text { water-born } \\
\text { polyurethane in } \\
1 \mathrm{M} \mathrm{Na}_{2} \mathrm{SO}_{4}\end{array}$ & 1 & 36.8 & $97 / 10,000$ & 93.4 & $16.38 / 1.04$ & $\begin{array}{l}\text { Wang et al. } \\
\text { (2020b) }\end{array}$ \\
\hline $\begin{array}{l}\text { S-doped } \\
\text { polyani- } \\
\text { line nano- } \\
\text { tubes@ } \\
\mathrm{Ni}(\mathrm{OH})_{2} \\
\text { nano- } \\
\text { sponge }\end{array}$ & $\begin{array}{l}\text { Poly(vinyl } \\
\text { alcohol) in } 3 \mathrm{M} \\
\mathrm{KOH}\end{array}$ & 2 & 622 & 10,000 & 97 & $70 / 136$ & $\begin{array}{l}\text { Bhaumik } \\
\text { et al. } \\
(2020)\end{array}$ \\
\hline $\begin{array}{l}\text { Phospho- } \\
\text { molybdic } \\
\text { acid/ } \\
\text { polypyr- } \\
\text { role }\end{array}$ & $\begin{array}{l}\text { Poly(vinyl } \\
\text { alcohol)- } \mathrm{H}_{2} \mathrm{SO}_{4}\end{array}$ & 0.5 & 162.1 & 1000 & 80 & $50.66 / 750$ & $\begin{array}{l}\text { Wang et al. } \\
(2020 \mathrm{c})\end{array}$ \\
\hline $\begin{array}{l}\text { Reduced } \\
\text { graphene } \\
\text { oxide/ } \\
\text { molyb- } \\
\text { denum } \\
\text { disulfide/ } \\
\text { poly } \\
\text { (3,4-ethyl- } \\
\text { enedioxy- } \\
\text { thiophene) }\end{array}$ & $1 \mathrm{M} \mathrm{H}_{2} \mathrm{SO}_{4}$ & $0.5 \mathrm{~mA} \mathrm{~cm}^{-2}$ & $241.81 \mathrm{mF} \mathrm{cm}^{-2}$ & 5000 & 93.7 & $1.44 \mu \mathrm{W} \mathrm{h} \mathrm{cm}-2 / 0.058 \mathrm{~mW} \mathrm{~cm}^{-2}$ & $\begin{array}{l}\text { Chen et al. } \\
\text { (2020) }\end{array}$ \\
\hline $\begin{array}{l}\text { Nitrogen- } \\
\text { doped } \\
\text { graphene/ } \\
\text { polyani- } \\
\text { line }\end{array}$ & $1 \mathrm{M} \mathrm{H}_{2} \mathrm{SO}_{4}$ & 0.5 & 620 & 5000 & 87.4 & $31.14 / 800$ & $\begin{array}{r}\text { Ge et al. } \\
(2020)\end{array}$ \\
\hline $\begin{array}{l}\text { Binary } \\
\text { MXenes } \\
\mathrm{Ti}_{3} \mathrm{C}_{2} / \\
\text { polypyr- } \\
\text { role }\end{array}$ & $2 \mathrm{M} \mathrm{H}_{2} \mathrm{SO}_{4}$ & $1.05 \mathrm{~mA} \mathrm{~cm}^{-2}$ & $109.4 \mathrm{mF} \mathrm{cm}^{-2}$ & 10,000 & 96 & $3.398 \mu \mathrm{W} \mathrm{h} \mathrm{cm}{ }^{-2} / 0.0845 \mathrm{Mw} \mathrm{cm}^{-2}$ & $\begin{array}{l}\text { Zhang et al. } \\
\text { (2020c) }\end{array}$ \\
\hline $\begin{array}{l}\mathrm{Na}- \\
\text { poly(vinyl } \\
\text { alcohol) }\end{array}$ & $\begin{array}{l}\text { Poly(vinyl alco- } \\
\text { hol) }\end{array}$ & $313 \mathrm{~mA} \mathrm{~g}^{-1}$ & $103.7 \mathrm{mF} \mathrm{cm}^{-2}$ & 1000 & $\sim 100$ & $6.5 / 161.4$ & $\begin{array}{l}\text { Wang et al. } \\
\text { (2020d) }\end{array}$ \\
\hline $\begin{array}{l}\text { Cyclo- } \\
\text { dextrin } \\
\text { polymer@ } \\
\text { poly- } \\
\text { aniline/ } \\
\text { carbon } \\
\text { nanotube }\end{array}$ & $1 \mathrm{M} \mathrm{H}_{2} \mathrm{SO}_{4}$ & 1 & 107.4 & 5000 & 97 & - & $\begin{array}{l}\text { Zhang et al. } \\
\text { (2020d) }\end{array}$ \\
\hline $\begin{array}{l}\text { Multi- } \\
\text { channels } \\
\text { carbon } \\
\text { nanofib- } \\
\text { ers@ } @ \mathrm{SnO}_{2} \\
\end{array}$ & $6 \mathrm{M} \mathrm{KOH}$ & 0.5 & 406 & 10,000 & 95 & $11.5 / 451$ & $\begin{array}{c}\text { Cao et al. } \\
(2020)\end{array}$ \\
\hline
\end{tabular}


Table 3 (continued)

\begin{tabular}{|c|c|c|c|c|c|c|c|}
\hline $\begin{array}{l}\text { Electrode } \\
\text { material }\end{array}$ & Electrolyte & $\begin{array}{l}\text { Current den- } \\
\text { sity }\left(\mathrm{A} \mathrm{g}^{-1}\right)\end{array}$ & $\begin{array}{l}\text { Specific capaci- } \\
\text { tance }\left(\mathrm{F} \mathrm{g}^{-1}\right) / \\
\text { areal capacitance } \\
\left(\mathrm{mF} \mathrm{cm}^{-2}\right)\end{array}$ & $\begin{array}{l}\text { Stability } \\
\% / \text { no. of } \\
\text { cycles }\end{array}$ & $\begin{array}{l}\text { Retained } \\
\text { specific } \\
\text { capaci- } \\
\text { tance \% }\end{array}$ & $\begin{array}{l}\text { Energy density }\left(\mathrm{W} \mathrm{h} \mathrm{kg}^{-1}\right) / \text { power } \\
\text { density }\left(\mathrm{kW} \mathrm{kg}^{-1}\right)\end{array}$ & References \\
\hline $\begin{array}{l}\text { Poly }(3,4- \\
\text { ethylenedi- } \\
\text { oxythioxy- } \\
\text { thiophene- } \\
\text { co-methyl- } \\
\text { pyrrole) }\end{array}$ & $0.5 \mathrm{M} \mathrm{LiClO} 4$ & 0.5 & 69.2 & 5000 & 65.4 & - & $\begin{array}{l}\text { Lacerda } \\
\text { et al. } \\
(2020)\end{array}$ \\
\hline $\begin{array}{l}\text { Polyester } \\
\text { (PET)/ } \\
\text { metal } \\
\text { organic } \\
\text { frame- } \\
\text { works/ } \\
\text { reduced } \\
\text { graphene } \\
\text { oxide }\end{array}$ & $\begin{array}{l}\text { Poly(vinyl alco- } \\
\text { hol })+\mathrm{H}_{2} \mathrm{SO}_{4}\end{array}$ & $0.05 \mathrm{~mA} \mathrm{~cm}^{-2}$ & $510 \mathrm{mF} \mathrm{cm}^{-2}$ & 1000 & 85 & $64 \mu \mathrm{W} \mathrm{h} \mathrm{cm}{ }^{-3} / 0.6 \mathrm{~mW} \mathrm{~cm}{ }^{-3}$ & $\begin{array}{l}\text { Barakzehi } \\
\text { et al. } \\
(2020)\end{array}$ \\
\hline Polypyrrole & $1 \mathrm{M} \mathrm{NaCl}$ & $0.25 \mathrm{~mA} \mathrm{~cm}^{-2}$ & 120 & 1000 & 88 & $1.16 \mu \mathrm{W} \mathrm{h} \mathrm{cm}-2 / 35 \mu \mathrm{W} \mathrm{cm}{ }^{-2}$ & $\begin{array}{l}\text { Zhao et al. } \\
\text { (2020) }\end{array}$ \\
\hline $\begin{array}{l}\text { Poly }(N- \\
\text { methyl- } \\
\text { pyrrole)@ } \\
\text { activated } \\
\text { carbon// } \\
\text { poly }(N- \\
\text { methyl- } \\
\text { pyrrole)@ } \\
\text { nickel } \\
\text { telluride } \\
\text { doped } \\
\text { with } \\
\text { selenide } \\
\text { (NiTe:Se) }\end{array}$ & $6 \mathrm{M} \mathrm{KOH}$ & 5 & $127 \mathrm{mF} \mathrm{cm}^{-2}$ & 1600 & 99.95 & $34 / 807$ & $\begin{array}{l}\text { Deshagani } \\
\text { et al. } \\
(2020)\end{array}$ \\
\hline $\begin{array}{l}\text { Polyaniline/ } \\
\text { multiwall } \\
\text { carbon } \\
\text { nanotubes } \\
2 \mathrm{wt} \%\end{array}$ & $1 \mathrm{M} \mathrm{H}_{2} \mathrm{SO}_{4}$ & 1 & 1183 & 1000 & 87 & 183.18 & $\begin{array}{l}\text { Awata et al. } \\
(2020)\end{array}$ \\
\hline $\begin{array}{l}\text { Nickel- } \\
\text { cobalt } \\
\text { hydroxide } \\
\text { hybrid } \\
\text { reduced } \\
\text { graphene- } \\
\text { based fiber }\end{array}$ & $\mathrm{PVA} / \mathrm{KOH}$ & 0.7 & 763 & 10,000 & 87 & $50.7 / 1642.1$ & $\begin{array}{c}\text { Zhou et al. } \\
\text { (2020) }\end{array}$ \\
\hline
\end{tabular}




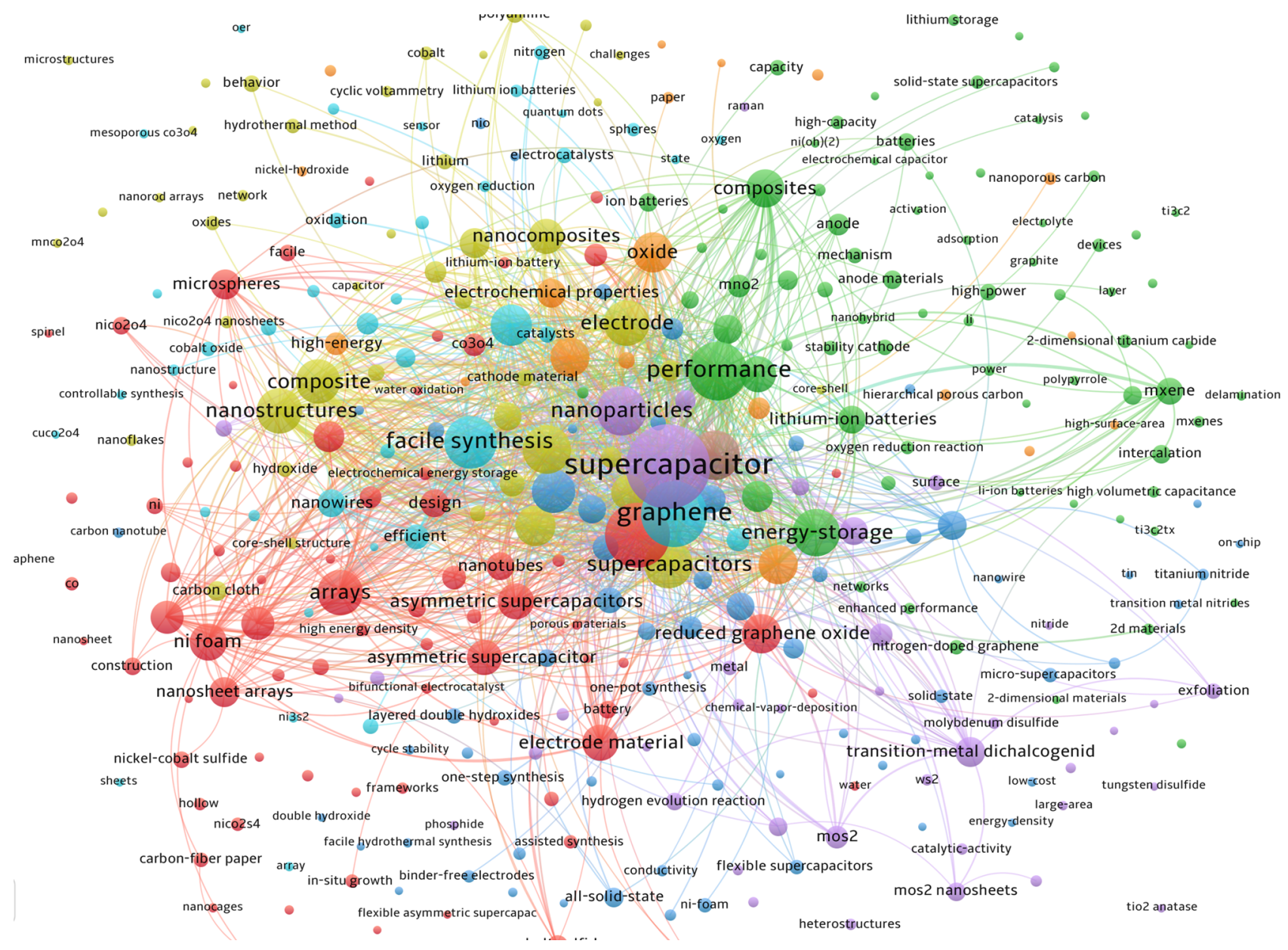

Fig. 33 Bibliometric network mapping of the supercapacitors research field in the last 5 years 


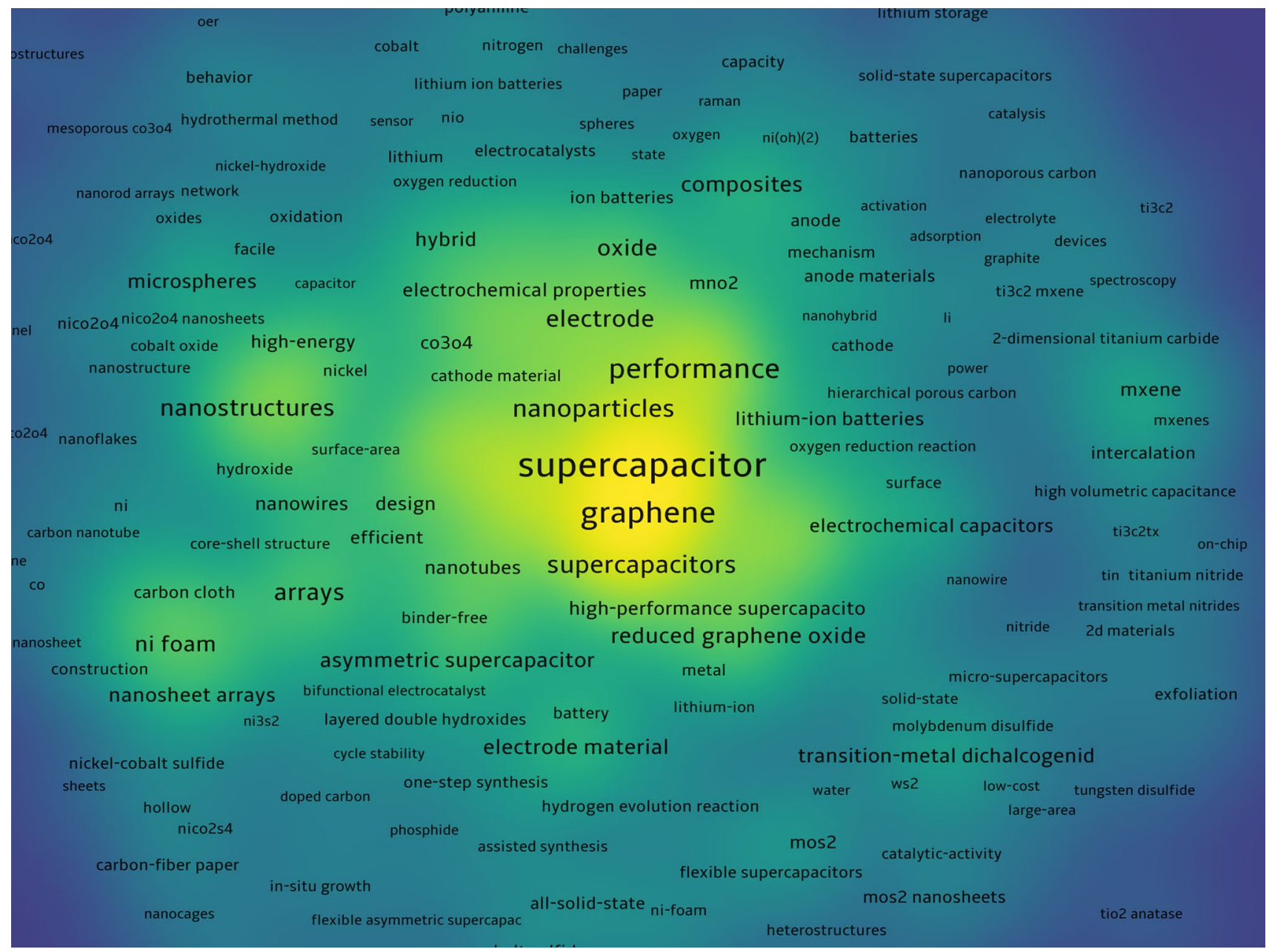

Fig. 34 Bibliometric density visualization mapping of the supercapacitors research field (2015-2020)

Acknowledgements The authors acknowledge the Materials Science Unit, National Center for Radiation Research and Technology, Egypt, for supporting this study under the project "Synthesizing and Characterizations of Nanostructured Magnetic Materials for Energy storage applications". Also, the author, M. Abd Elkodous shows his deep gratitude to Nile University's vice president for research, Prof. Dr. Ahmed Radwan for his continued support. Furthermore, AES thanks the National Research grants from MINECO "Juan de la Cierva" [FJCI2018-037717]. The author would like to acknowledge the support given by the EPSRC project (ACCEPT Transitions, EP/S025545/1).

Open Access This article is licensed under a Creative Commons Attribution 4.0 International License, which permits use, sharing, adaptation, distribution and reproduction in any medium or format, as long as you give appropriate credit to the original author(s) and the source, provide a link to the Creative Commons licence, and indicate if changes were made. The images or other third party material in this article are included in the article's Creative Commons licence, unless indicated otherwise in a credit line to the material. If material is not included in the article's Creative Commons licence and your intended use is not permitted by statutory regulation or exceeds the permitted use, you will need to obtain permission directly from the copyright holder. To view a copy of this licence, visit http://creativecommons.org/licenses/by/4.0/.

\section{References}

Abbas YM et al (2019) Investigation of structural and magnetic properties of multiferroic $\mathrm{La}_{1-\mathrm{x}} \mathrm{Y}_{\mathrm{X}} \mathrm{FeO}_{3}$ Perovskites, prepared by citrate auto-combustion technique. J Magn Magn Mater 482:66-74. https://doi.org/10.1016/j.jmmm.2019.03.056

Abdel Maksoud MIA et al (2020a) Insight on water remediation application using magnetic nanomaterials and biosorbents. Coord Chem Rev 403:213096. https://doi.org/10.1016/j.ccr.2019.21309 6

Abdel Maksoud MIA et al (2020b) MANanostructured Mg substituted $\mathrm{Mn}-\mathrm{Zn}$ ferrites: a magnetic recyclable catalyst for outstanding photocatalytic and antimicrobial potentials. J Hazard Mater. https ://doi.org/10.1016/j.jhazmat.2020.123000

Abirami R et al (2020) Synthesis and characterization of $\mathrm{ZnTiO}_{3}$ and Ag doped $\mathrm{ZnTiO}_{3}$ perovskite nanoparticles and their enhanced photocatalytic and antibacterial activity. J Solid State Chem 281:121019. https://doi.org/10.1016/j.jssc.2019.121019

Acharya $\mathrm{J}$ et al (2020) Facile one pot sonochemical synthesis of $\mathrm{CoFe}_{2} \mathrm{O}_{4} / \mathrm{MWCNTs}$ hybrids with well-dispersed MWCNTs for asymmetric hybrid supercapacitor applications. Int J Hydrog Energy 45:3073-3085. https://doi.org/10.1016/j.ijhyd ene.2019.11.169 
Ajay A et al (2015) $2 \mathrm{D}$ amorphous frameworks of $\mathrm{NiMoO}_{4}$ for supercapacitors: defining the role of surface and bulk controlled diffusion processes. Appl Surf Sci 326:39-47. https://doi. org/10.1016/j.apsusc.2014.11.016

Ajmal M (2009) Fabrication and physical characterization of $\mathrm{Ni}_{1-\mathrm{X}} \mathrm{Znxe}_{2} \mathrm{O}_{4}$ and $\mathrm{Cu}_{1-\mathrm{X}} \mathrm{ZnxFe}_{2} \mathrm{O}_{4}$ ferrites. Quaid-i-Azam University, Islamabad

Alamro T, Ram MK (2017) Polyethylenedioxythiophene and molybdenum disulfide nanocomposite electrodes for supercapacitor applications. Electrochim Acta 235:623-631. https://doi. org/10.1016/j.electacta.2017.03.102

Alcalá O et al (2017) Toroidal cores of MnxCo1 - xFe2O4/PAA nanocomposites with potential applications in antennas. Mater Chem Phys 192:17-21. https://doi.org/10.1016/j.matchemphy s.2017.01.035

Alvarez $\mathrm{G}$ et al (2016) About room temperature ferromagnetic behavior in $\mathrm{BaTiO}_{3}$ perovskite. J Magn Magn Mater 401:196-199. https ://doi.org/10.1016/j.jmmm.2015.10.031

Amirabadizadeh A et al (2017) Synthesis of ferrofluids based on cobalt ferrite nanoparticles: Influence of reaction time on structural, morphological and magnetic properties. J Magn Magn Mater 434:78-85. https://doi.org/10.1016/j.jmmm.2017.03.023

Amiri S, Shokrollahi H (2013) The role of cobalt ferrite magnetic nanoparticles in medical science. Mater Sci Eng, C 33:1-8. https:// doi.org/10.1016/j.msec.2012.09.003

Anitha T et al (2019) Facile synthesis of $\mathrm{ZnWO}_{4} @ \mathrm{WS}_{2}$ cauliflowerlike structures for supercapacitors with enhanced electrochemical performance. J Electroanal Chem 841:86-93. https://doi. org/10.1016/j.jelechem.2019.04.034

Ansari SA et al (2017) Mechanically exfoliated $\mathrm{MoS}_{2}$ sheet coupled with conductive polyaniline as a superior supercapacitor electrode material. J Colloid Interface Sci 504:276-282. https://doi. org/10.1016/j.jcis.2017.05.064

Anu M, Saravanakumar M (2017) A review on the classification, characterisation, synthesis of nanoparticles and their application. IOP Conf Ser Mater Sci Eng. https://doi.org/10.1088/1757$899 x / 263 / 3 / 032019$

Anupama $\mathrm{M}$ et al (2017) Investigation on impedance response and dielectric relaxation of $\mathrm{Ni}-\mathrm{Zn}$ ferrites prepared by self-combustion technique. J Alloys Compd 706:554-561. https://doi. org/10.1016/j.jallcom.2017.02.241

Arruebo $\mathrm{M}$ et al (2007) Magnetic nanoparticles for drug delivery. Nano Today 2:22-32. https://doi.org/10.1016/S1748-0132(07)70084-1

Arsalani $\mathrm{N}$ et al (2018) Novel PANI/ $\mathrm{MnFe}_{2} \mathrm{O}_{4}$ nanocomposite for low-cost supercapacitors with high rate capability. J Mater Sci: Mater Electron 29:6077-6085. https://doi.org/10.1007/s1085 4-018-8582-6

Arshad M et al (2020) Fabrication, structure, and frequency-dependent electrical and dielectric properties of $\mathrm{Sr}$-doped $\mathrm{BaTiO}_{3}$ ceramics. Ceram Int 46:2238-2246. https://doi.org/10.1016/j.ceram int.2019.09.208

Arul NS et al (2018) Facile synthesis of ZnS/MnS nanocomposites for supercapacitor applications. J Solid State Electrochem 22:303313. https://doi.org/10.1007/s10008-017-3782-1

Asen $\mathrm{P}$ et al (2019) One step synthesis of $\mathrm{SnS}_{2}-\mathrm{SnO}_{2}$ nano-heterostructured as an electrode material for supercapacitor applications. J Alloys Compd 782:38-50. https://doi.org/10.1016/j.jallc om.2018.12.176

Ashour A et al (2014) Electrical and thermal behavior of PS/ferrite composite. J Magn Magn Mater 369:260-267. https://doi. org/10.1016/j.jmmm.2014.06.005

Ashour A et al (2018) Antimicrobial activity of metal-substituted cobalt ferrite nanoparticles synthesized by sol-gel technique. Particuology 40:141-151. https://doi.org/10.1016/j.partic.2017.12.001
Assirey EAR (2019) Perovskite synthesis, properties and their related biochemical and industrial application. Saudi Pharm J 27:817829. https://doi.org/10.1016/j.jsps.2019.05.003

Atta NF et al (2019) Effect of B-site doping on $\mathrm{Sr}_{2} \mathrm{PdO}_{3}$ perovskite catalyst activity for non-enzymatic determination of glucose in biological fluids. J Electroanal Chem 852:113523. https://doi. org/10.1016/j.jelechem.2019.113523

Awasthi GP et al (2018) Layer-structured partially reduced graphene oxide sheathed mesoporous $\mathrm{MoS}_{2}$ particles for energy storage applications. J Colloid Interface Sci 518:234-241. https://doi. org/10.1016/j.jcis.2018.02.043

Awata R et al (2020) High performance supercapacitor based on camphor sulfonic acid doped polyaniline/multiwall carbon nanotubes nanocomposite. Electrochim Acta 347:136229. https:// doi.org/10.1016/j.electacta.2020.136229

Baharuddin NA et al (2019) Structural, morphological, and electrochemical behavior of titanium-doped $\mathrm{SrFe}_{1-\mathrm{x}} \mathrm{Ti}_{\mathrm{x}} \mathrm{O}_{3-\delta}(\mathrm{x}=0.1-$ 0.5 ) perovskite as a cobalt-free solid oxide fuel cell cathode. Ceram Int 45:12903-12909. https://doi.org/10.1016/j.ceram int.2019.03.216

Balakrishnan B et al (2019) Facile synthesis of pristine $\mathrm{FeS}_{2}$ microflowers and hybrid $\mathrm{rGO}-\mathrm{FeS}_{2}$ microsphere electrode materials for high performance symmetric capacitors. J Ind Eng Chem 71:191-200. https://doi.org/10.1016/j.jiec.2018.11.022

Bandyopadhyay P et al (2020) Zinc-nickel-cobalt oxide@ $\mathrm{NiMoO}_{4}$ core-shell nanowire/nanosheet arrays for solid state asymmetric supercapacitors. Chem Eng J 384:123357. https://doi. org/10.1016/j.cej.2019.123357

Barakzehi M et al (2020) MOF-modified polyester fabric coated with reduced graphene oxide/polypyrrole as electrode for flexible supercapacitors. Electrochim Acta 336:135743. https://doi. org/10.1016/j.electacta.2020.135743

Barik R et al (2019) Stannous sulfide nanoparticles for supercapacitor application. Appl Surf Sci 472:112-117. https://doi. org/10.1016/j.apsusc.2018.03.172

Basuki JS et al (2013) Using fluorescence lifetime imaging microscopy to monitor theranostic nanoparticle uptake and intracellular doxorubicin release. ACS Nano 7:10175-10189. https:// doi.org/10.1021/nn404407g

Bhagwan J et al (2020) Aqueous asymmetric supercapacitors based on $\mathrm{ZnCo}_{2} \mathrm{O}_{4}$ nanoparticles via facile combustion method. J Alloys Compd 815:152456. https://doi.org/10.1016/j.jallc om.2019.152456

Bhame SD (2007) Structural, magnetic, and magnetostrictive properties of substituted lanthanum manganites and spinel ferrites. CSIR-National Chemical Laboratory, Pune. http://dspace.ncl. res.in:8080/xmlui/bitstream/handle/20.500.12252/2592/TH159 0 .pdf? sequence $=1$. Accsessed 23/07/2020

Bhaumik M et al (2020) High-performance supercapacitors based on $\mathrm{S}$-doped polyaniline nanotubes decorated with $\mathrm{Ni}(\mathrm{OH})_{2}$ nanosponge and onion-like carbons derived from used car tyres. Electrochim Acta 342:136111. https://doi.org/10.1016/j.elect acta.2020.136111

Boudad L et al (2019) Structural, morphological, spectroscopic, and dielectric properties of $\mathrm{SmFe}_{0.5} \mathrm{Cr}_{0.5} \mathrm{O}_{3}$. Mater Today Proc 13:646-653. https://doi.org/10.1016/j.matpr.2019.04.024

Budhiraju VS et al (2017) Structurally stable hollow mesoporous graphitized carbon nanofibers embedded with $\mathrm{NiMoO}_{4}$ nanoparticles for high performance asymmetric supercapacitors. Electrochim Acta 238:337-348. https://doi.org/10.1016/j.elect acta.2017.04.039

Burke A, Zhao H (2015) Applications of supercapacitors in electric and hybrid vehicles. In: ITS

Cai D et al (2013) Comparison of the electrochemical performance of $\mathrm{NiMoO}_{4}$ nanorods and hierarchical nanospheres 
for supercapacitor applications. ACS Appl Mater Interfaces 5:12905-12910. https://doi.org/10.1021/am403444v

Cai D et al (2014a) Enhanced performance of supercapacitors with ultrathin mesoporous $\mathrm{NiMoO}_{4}$ nanosheets. Electrochim Acta 125:294-301. https://doi.org/10.1016/j.electacta.2014.01.049

Cai F et al (2014b) Hierarchical CNT@ $\mathrm{NiCo}_{2} \mathrm{O}_{4}$ core-shell hybrid nanostructure for high-performance supercapacitors. J Mater Chem A 2:11509-11515. https://doi.org/10.1039/C4TA01235F

Cai W et al (2016) Transition metal sulfides grown on graphene fibers for wearable asymmetric supercapacitors with high volumetric capacitance and high energy density. Sci Rep 6:26890. https:// doi.org/10.1038/srep26890

Cai Y-Z et al (2019) Tailoring $\mathrm{rGO}-\mathrm{NiFe}_{2} \mathrm{O}_{4}$ hybrids to tune transport of electrons and ions for supercapacitor electrodes. J Alloys Compd 811:152011. https://doi.org/10.1016/j.jallc om.2019.152011

Cao Y et al (2015a) Structure, morphology and electrochemical properties of $\mathrm{La}_{\mathrm{x}} \mathrm{Sr}_{1-\mathrm{x}} \mathrm{Co}_{0.1} \mathrm{Mn}_{0.9} \mathrm{O}_{3-\delta}$ perovskite nanofibers prepared by electrospinning method. J Alloys Compd 624:31-39. https://doi. org/10.1016/j.jallcom.2014.10.178

Cao Y et al (2015b) Sr-doped lanthanum nickelate nanofibers for high energy density supercapacitors. Electrochim Acta 174:41-50. https://doi.org/10.1016/j.electacta.2015.05.131

Cao X et al (2017) Structural, optical and ferroelectric properties of $\mathrm{KNi}_{\mathrm{x}} \mathrm{Nb}_{1-\mathrm{x}} \mathrm{O}_{3}$ single crystals. J Solid State Chem 256:234-238. https://doi.org/10.1016/j.jssc.2017.08.032

Cao M et al (2020) Lignin-based multi-channels carbon nanofibers@ $\mathrm{SnO}_{2}$ nanocomposites for high-performance supercapacitors. Electrochim Acta 345:136172. https://doi.org/10.1016/j.elect acta.2020.136172

Chandel $\mathrm{M}$ et al (2018) Synthesis of multifunctional $\mathrm{CuFe}_{2} \mathrm{O}_{4}$-reduced graphene oxide nanocomposite: an efficient magnetically separable catalyst as well as high performance supercapacitor and first-principles calculations of its electronic structures. RSC Adv 8:27725-27739. https://doi.org/10.1039/C8RA05393F

Chandrasekaran NI et al (2018) High-performance asymmetric supercapacitor from nanostructured tin nickel sulfide $\left(\mathrm{SnNi}_{2} \mathrm{~S}_{4}\right)$ synthesized via microwave-assisted technique. J Mol Liq 266:649657. https://doi.org/10.1016/j.molliq.2018.06.084

Chang C et al (2017) Layered $\mathrm{MoS}_{2} / \mathrm{PPy}$ nanotube composites with enhanced performance for supercapacitors. J Mater Sci: Mater Electron 28:1777-1784. https://doi.org/10.1007/s1085 4-016-5725-5

Chao J et al (2018) Sandwiched $\mathrm{MoS}_{2}$ /polyaniline nanosheets array vertically aligned on reduced graphene oxide for high performance supercapacitors. Electrochim Acta 270:387-394. https:// doi.org/10.1016/j.electacta.2018.03.072

Chauhan $\mathrm{H}$ et al (2017) Development of $\mathrm{SnS}_{2} / \mathrm{RGO}$ nanosheet composite for cost-effective aqueous hybrid supercapacitors. Nanotechnology 28:025401. https://doi.org/10.1088/1361$6528 / 28 / 2 / 025401$

Chen T, Dai L (2013) Carbon nanomaterials for high-performance supercapacitors. Mater Today 16:272-280. https://doi. org/10.1016/j.mattod.2013.07.002

Chen J-T, Hsu C-S (2011) Conjugated polymer nanostructures for organic solar cell applications. Polym Chem 2:2707-2722. https ://doi.org/10.1039/C1PY00275A

Chen $\mathrm{Y}$ et al (2007) Crystal growth and magnetic property of orthorhombic $\mathrm{RMnO}_{3}(\mathrm{R}=\mathrm{Sm}-\mathrm{Ho})$ perovskites by mild hydrothermal synthesis. J Cryst Growth 305:242-248. https://doi. org/10.1016/j.jcrysgro.2007.03.052

Chen P et al (2013) Hydrothermal synthesis of macroscopic nitrogendoped graphene hydrogels for ultrafast supercapacitor. Nano Energy 2:249-256. https://doi.org/10.1016/j.nanoen.2012.09.003

Chen $\mathrm{Y}$ et al (2015) Flexible all-solid-state asymmetric supercapacitor assembled using coaxial $\mathrm{NiMoO}_{4}$ nanowire arrays with chemically integrated conductive coating. Electrochim Acta 178:429-438. https://doi.org/10.1016/j.electacta.2015.08.040

Chen JH et al (2016a) Mixed-phase $\mathrm{Ni}-\mathrm{Al}$ as barrier layer against perovskite oxides to react with $\mathrm{Cu}$ for ferroelectric memory with $\mathrm{Cu}$ metallization. J Alloys Compd 666:197-203. https://doi. org/10.1016/j.jallcom.2016.01.100

Chen J et al (2016b) Pyrite $\mathrm{FeS}_{2}$ nanobelts as high-performance anode material for aqueous pseudocapacitor. Electrochim Acta 222:172-176. https://doi.org/10.1016/j.electacta.2016.10.181

Chen $\mathrm{Y}$ et al (2017a) In situ growth of polypyrrole onto three-dimensional tubular $\mathrm{MoS}_{2}$ as an advanced negative electrode material for supercapacitor. Electrochim Acta 246:615-624. https://doi. org/10.1016/j.electacta.2017.06.102

Chen JS et al (2017b) Rational design of self-supported $\mathrm{Ni}_{3} \mathrm{~S}_{2}$ nanosheets array for advanced asymmetric supercapacitor with a superior energy density. ACS Appl Mater Interfaces 9:496-504. https://doi.org/10.1021/acsami.6b14746

Chen X et al (2018a) Preparation of a $\mathrm{MoS}_{2} /$ carbon nanotube composite as an electrode material for high-performance supercapacitors. RSC Adv 8:29488-29494. https://doi.org/10.1039/c8ra0 $5158 \mathrm{e}$

Chen L et al (2018b) Two-dimensional porous carbon nanosheets from exfoliated nanopaper-like biomass. Mater Lett 232:187-190. https://doi.org/10.1016/j.matlet.2018.08.111

Chen C et al (2019a) Reduced $\mathrm{ZnCo}_{2} \mathrm{O}_{4} @ \mathrm{NiMoO}_{4} \mathrm{H}_{2} \mathrm{O}$ heterostructure electrodes with modulating oxygen vacancies for enhanced aqueous asymmetric supercapacitors. J Power Sources 409:112-122. https://doi.org/10.1016/j.jpowsour.2018.10.066

Chen $\mathrm{H}$ et al (2019b) Upcycling food waste digestate for energy and heavy metal remediation applications. Resour Conserv Recycl X 3:100015. https://doi.org/10.1016/j.rcrx.2019.100015

Chen X et al (2019c) Natural plant template-derived cellular framework porous carbon as a high-rate and long-life electrode material for energy storage. ACS Sustain Chem Eng 7:5845-5855. https:// doi.org/10.1021/acssuschemeng.8b05777

Chen Y et al (2020) Excellent performance of flexible supercapacitor based on the ternary composites of reduced graphene oxide/ molybdenum disulfide/poly(3,4-ethylenedioxythiophene). Electrochim Acta 330:135205. https://doi.org/10.1016/j.elect acta.2019.135205

Cheng Q et al (2011) Graphene and nanostructured $\mathrm{MnO}_{2}$ composite electrodes for supercapacitors. Carbon 49:2917-2925. https:// doi.org/10.1016/j.carbon.2011.02.068

Cheng $\mathrm{F}$ et al (2020a) Boosting the supercapacitor performances of activated carbon with carbon nanomaterials. J Power Sources 450:227678. https://doi.org/10.1016/j.jpowsour.2019.227678

Cheng JP et al (2020b) Recent research of core-shell structured composites with $\mathrm{NiCo}_{2} \mathrm{O}_{4}$ as scaffolds for electrochemical capacitors. Chem Eng J 393:124747. https://doi.org/10.1016/j. cej. 2020.124747

Choudhary N et al (2016) High-performance one-body core/shell nanowire supercapacitor enabled by conformal growth of capacitive 2D WS 2 layers. ACS Nano 10:10726-10735. https://doi. org/10.1021/acsnano.6b06111

Choudhary N et al (2020) Correlation between magnetic and transport properties of rare earth doped perovskite manganites $\mathrm{La}_{0.6} \mathrm{R}_{0.1} \mathrm{Ca}_{0.3} \mathrm{MnO}_{3}(\mathrm{R}=\mathrm{La}, \mathrm{Nd}, \mathrm{Sm}, \mathrm{Gd}$, and Dy) synthesized by Pechini process. Mater Chem Phys 242:122482. https://doi. org/10.1016/j.matchemphys.2019.122482

Chu $\mathrm{H}$ et al (2018) $\mathrm{Ni}$, Co and $\mathrm{Mn}$ doped $\mathrm{SnS}_{2}$-graphene aerogels for supercapacitors. J Alloys Compd 767:583-591. https://doi. org/10.1016/j.jallcom.2018.07.126

Cui X et al (2017) Dopamine adsorption precursor enables N-doped carbon sheathing of $\mathrm{MoS}_{2}$ nanoflowers for all-around enhancement of supercapacitor performance. J Alloys Compd 693:955963. https://doi.org/10.1016/j.jallcom.2016.09.173 
Cullity BD, Graham CD (2011) Introduction to magnetic materials. Wiley, New York

Dabrowski B et al (2005) Structural, transport, and magnetic properties of $\mathrm{RMnO}_{3}$ perovskites ( $\left.\mathrm{R}=\mathrm{La}, \mathrm{Pr}, \mathrm{Nd}, \mathrm{Sm}, 153 \mathrm{Eu}, \mathrm{Dy}\right)$. J Solid State Chem 178:629-637. https://doi.org/10.1016/j. jssc.2004.12.006

Dar M, Varshney D (2017) Effect of d-block element $\mathrm{Co}^{2+}$ substitution on structural, Mössbauer and dielectric properties of spinel copper ferrites. J Magn Magn Mater 436:101-112. https://doi. org/10.1016/j.jmmm.2017.04.046

Das T, Verma B (2019) Synthesis of polymer composite based on polyaniline-acetylene black-copper ferrite for supercapacitor electrodes. Polymer 168:61-69. https://doi.org/10.1016/j.polym er.2019.01.058

Deganello F et al (2016) Electrochemical properties of Ce-doped $\mathrm{SrFeO}_{3}$ perovskites-modified electrodes towards hydrogen peroxide oxidation. Electrochim Acta 190:939-947. https://doi. org/10.1016/j.electacta.2015.12.101

Deshagani S et al (2019) Nickel cobaltite@ poly(3,4-ethylenedioxypyrrole) and carbon nanofiber interlayer based flexible supercapacitors. Nanoscale 11:2742-2756. https://doi.org/10.1039/C8NR0 $8645 \mathrm{~A}$

Deshagani S et al (2020) Altered crystal structure of nickel telluride by selenide doping and a poly(N-methylpyrrole) coating amplify supercapacitor performance. Electrochim Acta 345:136200. https ://doi.org/10.1016/j.electacta.2020.136200

Ding J et al (2013) Carbon nanosheet frameworks derived from peat moss as high performance sodium ion battery anodes. ACS Nano 7:11004-11015. https://doi.org/10.1021/nn404640c

Ding R et al (2017) Perovskite KNi 0.8 Co 0.2 F 3 nanocrystals for supercapacitors. J Mater Chem A 5:17822-17827. https://doi. org/10.1039/C7TA05209J

Dirican $\mathrm{M}$ et al (2020) Polyaniline/ $\mathrm{MnO}_{2} /$ porous carbon nanofiber electrodes for supercapacitors. J Electroanal Chem 861:113995. https ://doi.org/10.1016/j.jelechem.2020.113995

Dutta S, De S (2018) $\mathrm{MoS}_{2}$ Nanosheet/rGO hybrid: an electrode material for high performance thin film supercapacitor, vol 5. Elsevier, Amsterdam, pp 9771-9775. https://doi.org/10.1016/j.matpr .2017.10.165

Dwivedi GD et al (2015) Low temperature magnetic and transport properties of LSMO-PZT nanocomposites. RSC Adv 5:3074830757. https://doi.org/10.1039/C5RA04101E

Eftekhari A (2017) Tungsten dichalcogenides $\left(\mathrm{WS}_{2}, \mathrm{WSe}_{2}\right.$, and $\left.\mathrm{WTe}_{2}\right)$ : materials chemistry and applications, vol 5. Royal Society of Chemistry, London, pp 18299-18325. https://doi.org/10.1039/ C7TA04268J

El Moussaoui H et al (2016) Synthesis and magnetic properties of tin spinel ferrites doped manganese. J Magn Magn Mater 405:181186. https://doi.org/10.1016/j.jmmm.2015.12.059

El-Kady MF et al (2016) Graphene for batteries, supercapacitors and beyond. Nat Rev Mater 1:16033. https://doi.org/10.1038/natre vmats. 2016.33

Elkholy AE et al (2017) Nanostructured spinel manganese cobalt ferrite for high-performance supercapacitors. RSC Adv 7:51888-51895. https://doi.org/10.1039/C7RA11020K

Elseman AM et al (2020) $\mathrm{CoFe}_{2} \mathrm{O}_{4} @$ carbon spheres electrode: a one-step solvothermal method for enhancing the electrochemical performance of hybrid supercapacitors. ChemElectroChem 7:526-534. https://doi.org/10.1002/celc.202000005

Elsiddig ZA et al (2017) Modulating $\mathrm{Mn}^{4+}$ ions and oxygen vacancies in nonstoichiometric $\mathrm{LaMnO}_{3}$ perovskite by a facile solgel method as high-performance supercapacitor electrodes. Electrochim Acta 253:422-429. https://doi.org/10.1016/j.elect acta.2017.09.076

Fan LQ et al (2015) Facile one-step hydrothermal preparation of molybdenum disulfide/carbon composite for use in supercapacitor. Int $\mathbf{J}$
Hydrog Energy 40:10150-10157. https://doi.org/10.1016/j.ijhyd ene.2015.06.061

Fang L et al (2017) Flower-like nanoarchitecture assembled from $\mathrm{Bi}_{2} \mathrm{~S}_{3}$ nanorod/MoS $\mathrm{S}_{2}$ nanosheet heterostructures for high-performance supercapacitor electrodes. Colloids Surf A 535:41-48. https:// doi.org/10.1016/j.colsurfa.2017.09.022

Fang L et al (2018) Three-dimensional flower-like $\mathrm{MoS}_{2}-\mathrm{CoSe}_{2}$ heterostructure for high performance superccapacitors. J Colloid Interface Sci 512:282-290. https://doi.org/10.1016/j.jcis.2017.10.072

Farid MT et al (2017) Magnetic and electric behavior of praseodymium substituted CuPryFe2-yO4 ferrites. J Magn Magn Mater 422:337-343. https://doi.org/10.1016/j.jmmm.2016.09.016

Frackowiak E et al (2006) Supercapacitors based on conducting polymers/nanotubes composites. J Power Sources 153:413-418. https ://doi.org/10.1016/j.jpowsour.2005.05.030

Galal A et al (2018) Enhancing the specific capacitance of $\mathrm{SrRuO}_{3}$ and reduced graphene oxide in $\mathrm{NaNO}_{3}, \mathrm{H}_{3} \mathrm{PO}_{4}$ and $\mathrm{KOH}$ electrolytes. Electrochim Acta 260:738-747. https://doi.org/10.1016/j.elect acta.2017.12.026

Galasso FS (2013) Structure, properties and preparation of perovskitetype compounds: international series of monographs in solid state physics. Elsevier, Amsterdam. https://doi.org/10.1016/ C2013-0-02117-2

Gao H et al (2012) High-performance asymmetric supercapacitor based on graphene hydrogel and nanostructured $\mathrm{MnO}_{2}$. ACS Appl Mater Interfaces 4:2801-2810. https://doi.org/10.1021/ am300455d

Gao S et al (2016a) Ultrathin $\mathrm{Co}_{3} \mathrm{O}_{4}$ layers realizing optimized $\mathrm{CO}_{2}$ electroreduction to formate. Angew Chem Int Ed 55:698-702. https://doi.org/10.1002/anie.201509800

Gao L et al (2016b) A coaxial yarn electrode based on hierarchical $\mathrm{MoS}_{2}$ nanosheets/carbon fiber tows for flexible solid-state supercapacitors. RSC Adv 6:57190-57198. https://doi.org/10.1039/ C6RA10178J

Gao Y-P et al (2018a) High-performance symmetric supercapacitor based on flower-like zinc molybdate. J Alloys Compd 731:11511158. https://doi.org/10.1016/j.jallcom.2017.10.161

Gao YP et al (2018b) $\mathrm{MoS}_{2}$ nanosheets assembling three-dimensional nanospheres for enhanced-performance supercapacitor. J Alloys Compd 741:174-181. https://doi.org/10.1016/j.jallc om.2018.01.110

Gao J et al (2018c) Free-standing $\mathrm{WS}_{2}$-MWCNTs hybrid paper integrated with polyaniline for high-performance flexible supercapacitor. J Nanopart Res. https://doi.org/10.1007/s1105 $1-018-4409-\mathrm{x}$

Gao W et al (2020) A review of flexible perovskite oxide ferroelectric films and their application. J Materiomics 6:1-16. https://doi. org/10.1016/j.jmat.2019.11.001

Ge M et al (2020) Hierarchical nanocomposite that coupled nitrogendoped graphene with aligned PANI cores arrays for high-performance supercapacitor. Electrochim Acta 330:135236. https://doi. org/10.1016/j.electacta.2019.135236

Geng P et al (2018) Transition metal sulfides based on graphene for electrochemical energy storage. Adv Energy Mater 8:1703259. https://doi.org/10.1002/aenm.201703259

George $\mathrm{G}$ et al (2018) Effect of doping on the performance of highcrystalline $\mathrm{SrMnO}_{3}$ perovskite nanofibers as a supercapacitor electrode. Ceram Int 44:21982-21992. https://doi.org/10.1016/j. ceramint.2018.08.313

Ghafoor A et al (2016) Structural and electromagnetic studies of

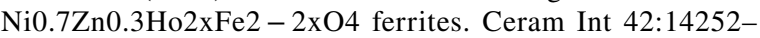
14256. https://doi.org/10.1016/j.ceramint.2016.06.054

Girishkumar G et al (2010) Lithium-air battery: promise and challenges. J Phys Chem Lett 1:2193-2203. https://doi.org/10.1021/ jz1005384 
Gokon N et al (2019) Thermochemical behavior of perovskite oxides based on $\mathrm{La}_{\mathrm{x}} \mathrm{Sr}_{1-\mathrm{x}}(\mathrm{Mn}, \mathrm{Fe}, \mathrm{Co}) \mathrm{O}_{3-\delta}$ and $\mathrm{BaySr}_{1-\mathrm{y}} \mathrm{CoO}_{3-\delta}$ redox system for thermochemical energy storage at high temperatures. Energy 171:971-980. https://doi.org/10.1016/j.energ y.2019.01.081

Gong $\mathrm{H}$ et al (2018) Preparation and supercapacitive property of molybdenum disulfide $\left(\mathrm{MoS}_{2}\right)$ nanoflake arrays-tungsten trioxide $\left(\mathrm{WO}_{3}\right)$ nanorod arrays composite heterojunction: a synergistic effect of one-dimensional and two-dimensional nanomaterials. Electrochim Acta 263:409-416. https://doi.org/10.1016/j.elect acta.2018.01.072

Gopi CVVM et al (2020) Co9S8-Ni3S2/CuMn ${ }_{2} \mathrm{O}_{4}-\mathrm{NiMn}_{2} \mathrm{O}_{4}$ and $\mathrm{MnFe}_{2} \mathrm{O}_{4}-\mathrm{ZnFe}_{2} \mathrm{O}_{4} /$ graphene as binder-free cathode and anode materials for high energy density supercapacitors. Chem Eng J 381:122640. https://doi.org/10.1016/j.cej.2019.122640

Górka J, Jaroniec M (2010) Tailoring adsorption and framework properties of mesoporous polymeric composites and carbons by addition of organosilanes during soft-templating synthesis. J Phys Chem C 114:6298-6303. https://doi.org/10.1021/jp9117858

Govindasamy $\mathrm{M}$ et al (2019a) Facile sonochemical synthesis of perovskite-type $\mathrm{SrTiO}_{3}$ nanocubes with reduced graphene oxide nanocatalyst for an enhanced electrochemical detection of $\alpha$-amino acid (tryptophan). Ultrason Sonochem 56:193-199. https://doi. org/10.1016/j.ultsonch.2019.04.004

Govindasamy $\mathrm{M}$ et al (2019b) Fabrication of hierarchical $\mathrm{NiCo}_{2} \mathrm{~S}_{4} @$ $\mathrm{CoS}_{2}$ nanostructures on highly conductive flexible carbon cloth substrate as a hybrid electrode material for supercapacitors with enhanced electrochemical performance. Electrochim Acta 293:328-337. https://doi.org/10.1016/j.electacta.2018.10.051

Grabowska E (2016) Selected perovskite oxides: characterization, preparation and photocatalytic properties-a review. Appl Catal B Environ 186:97-126. https://doi.org/10.1016/j.apcat b.2015.12.035

Guan C et al (2015) Iron oxide-decorated carbon for supercapacitor anodes with ultrahigh energy density and outstanding cycling stability. ACS Nano 9:5198-5207. https://doi.org/10.1021/acsna no. 5 b00582

Guo B et al (2011) Soft-templated mesoporous carbon-carbon nanotube composites for high performance lithium-ion batteries. Adv Mater 23:4661-4666. https://doi.org/10.1002/adma.201102032

Guo D et al (2014) High performance $\mathrm{NiMoO}_{4}$ nanowires supported on carbon cloth as advanced electrodes for symmetric supercapacitors. Nano Energy. 8:174-182. https://doi.org/10.1016/j.nanoe n.2014.06.002

Guo P et al (2017) Electrochemical properties of colloidal nanocrystal assemblies of manganese ferrite as the electrode materials for supercapacitors. J Mater Sci 52:5359-5365. https://doi. org/10.1007/s10853-017-0778-2

Gupta AK, Gupta M (2005a) Synthesis and surface engineering of iron oxide nanoparticles for biomedical applications. Biomaterials 26:3995-4021. https://doi.org/10.1016/j.biomateria 1s.2004.10.012

Gupta AK, Gupta M (2005b) Cytotoxicity suppression and cellular uptake enhancement of surface modified magnetic nanoparticles. Biomaterials 26:1565-1573. https://doi.org/10.1016/j.biomateria 1s.2004.05.022

Han C et al (2018) Vertical crosslinking $\mathrm{MoS}_{2} /$ three-dimensional graphene composite towards high performance supercapacitor. Chin Chem Lett 29:606-611. https://doi.org/10.1016/j.cclet .2018 .01 .017

Hao J et al (2015) Facile Synthesis of 3D hierarchical flower-like $\mathrm{Co} 3-\mathrm{xFexO} 4$ ferrite on nickel foam as high-performance electrodes for supercapacitors. Electrochim Acta 152:13-18. https:// doi.org/10.1016/j.electacta.2014.11.104

Hassan HS et al (2019) Assessment of zinc ferrite nanocrystals for removal of $134 \mathrm{Cs}$ and $152+154 \mathrm{Eu}$ radionuclides from nitric acid solution. J Mater Sci: Mater Electron. https://doi.org/10.1007/ s10854-019-02678-y

Hassoun J et al (2012) A metal-free, lithium-ion oxygen battery: a step forward to safety in lithium-air batteries. Nano Lett 12:57755779. https://doi.org/10.1021/n1303087j

Hatui G et al (2017) Template-free single pot synthesis of $\mathrm{SnS}_{2} @$ $\mathrm{Cu}_{2} \mathrm{O}$ /reduced graphene oxide (rGO) nanoflowers for high performance supercapacitors. New J Chem 41:2702-2716. https:// doi.org/10.1039/c6nj02965e

He W et al (2017) Flexible and high energy density asymmetrical supercapacitors based on core/shell conducting polymer nanowires/manganese dioxide nanoflakes. Nano Energy 35:242-250. https://doi.org/10.1016/j.nanoen.2017.03.045

Hekmat F et al (2020) Hybrid energy storage device from binderfree zinc-cobalt sulfide decorated biomass-derived carbon microspheres and pyrolyzed polyaniline nanotube-iron oxide. Energy Storage Mater 25:621-635. https://doi.org/10.1016/j. ensm.2019.09.022

Hennous $M$ et al (2019) Synthesis, structure and magnetic properties of multipod-shaped cobalt ferrite nanocrystals. New J Chem 43:10259-10269. https://doi.org/10.1039/C9NJ02237F

Hirel P et al (2015) Theoretical and experimental study of the core structure and mobility of dislocations and their influence on the ferroelectric polarization in perovskite $\mathrm{KNbO}_{3}$. Phys Rev B 92:214101. https://doi.org/10.1103/PhysRevB.92.214101

Hooch Antink W et al (2018) Recent progress in porous graphene and reduced graphene oxide-based nanomaterials for electrochemical energy storage devices. Adv Mater Interfaces 5:1701212. https:// doi.org/10.1002/admi.201701212

Hou J et al (2013) A new method for fabrication of graphene/polyaniline nanocomplex modified microbial fuel cell anodes. J Power Sources 224:139-144. https://doi.org/10.1016/j.jpows our.2012.09.091

Hou X et al (2018) Metal organic framework derived core-shell structured $\mathrm{Co}_{9} \mathrm{~S}_{8} @ \mathrm{~N}-\mathrm{C} @ \mathrm{MoS}_{2}$ nanocubes for supercapacitor. ACS Appl Energy Mater 1:3513-3520. https://doi.org/10.1021/acsae m.8b00773

Houshiar $\mathrm{M}$ et al (2014) Synthesis of cobalt ferrite $\left(\mathrm{CoFe}_{2} \mathrm{O}_{4}\right)$ nanoparticles using combustion, coprecipitation, and precipitation methods: a comparison study of size, structural, and magnetic properties. J Magn Magn Mater 371:43-48. https://doi.org/10.1016/j. jmmm.2014.06.059

Huang X et al (2012) Graphene-based composites. Chem Soc Rev 41:666-686. https://doi.org/10.1039/C1CS15078B

Huang KJ et al (2013a) Layered $\mathrm{MoS}_{2}$-graphene composites for supercapacitor applications with enhanced capacitive performance. Int J Hydrog Energy 38:14027-14034. https://doi.org/10.1016/j. ijhydene.2013.08.112

Huang KJ et al (2013b) Synthesis of polyaniline/2-dimensional graphene analog $\mathrm{MoS}_{2}$ composites for high-performance supercapacitor. Electrochim Acta 109:587-594. https://doi. org/10.1016/j.electacta.2013.07.168

Huang $\mathrm{L}$ et al (2015a) 3D interconnected porous $\mathrm{NiMoO}_{4}$ nanoplate arrays on $\mathrm{Ni}$ foam as high-performance binder-free electrode for supercapacitors. J Mater Chem A 3:22081-22087. https://doi. org/10.1039/C5TA05644F

Huang KJ et al (2015b) Synthesis of molybdenum disulfide/carbon aerogel composites for supercapacitors electrode material application. J Electroanal Chem 752:33-40. https://doi.org/10.1016/j. jelechem.2015.06.005

Huang L et al (2016a) Hierarchical core-shell $\mathrm{NiCo}_{2} \mathrm{O}_{4} @ \mathrm{NiMoO}_{4}$ nanowires grown on carbon cloth as integrated electrode for high-performance supercapacitors. Sci Rep 6:31465. https://doi. org/10.1038/srep31465 
Huang Y et al (2016b) Nanostructured polypyrrole as a flexible electrode material of supercapacitor. Nano Energy 22:422-438. https ://doi.org/10.1016/j.nanoen.2016.02.047

Huang Y et al (2016c) Enhanced cycling stability of $\mathrm{NiCo}_{2} \mathrm{~S}_{4} \mathrm{AtNiO}$ core-shell nanowire arrays for all-solid-state asymmetric supercapacitors. Sci Rep 6:1-10. https://doi.org/10.1038/srep38620

Huang F et al (2017a) One-step hydrothermal synthesis of $\mathrm{Ni}_{3} \mathrm{~S}_{4} @$ $\mathrm{MoS}_{2}$ nanosheet on carbon fiber paper as a binder-free anode for supercapacitor. J Mater Sci: Mater Electron 28:12747-12754. https://doi.org/10.1007/s10854-017-7100-6

Huang L et al (2017b) Ultrahigh-performance pseudocapacitor based on phase-controlled synthesis of $\mathrm{MoS}_{2}$ nanosheets decorated $\mathrm{Ni}_{3} \mathrm{~S}_{2}$ hybrid structure through annealing treatment. Appl Surf Sci 425:879-888. https://doi.org/10.1016/j.apsusc.2017.06.334

Huang Y et al (2018a) $\mathrm{NiMoO}_{4}$ nanorod deposited carbon sponges with ant-nest-like interior channels for high-performance pseudocapacitors. Inorg Chem Front 5:1594-1601. https://doi. org/10.1039/C8QI00247A

Huang F et al (2018b) One-step hydrothermal synthesis of a $\mathrm{CoS}_{2} @$ $\mathrm{MoS}_{2}$ nanocomposite for high-performance supercapacitors. J Alloys Compd 742:844-851. https://doi.org/10.1016/j.jallc om.2018.01.324

Hui $\mathrm{KN}$ et al (2016) Hierarchical chestnut-like $\mathrm{MnCo}_{2} \mathrm{O}_{4}$ nanoneedles grown on nickel foam as binder-free electrode for high energy density asymmetric supercapacitors. J Power Sources 330:195203. https://doi.org/10.1016/j.jpowsour.2016.08.116

Hussain S et al (2020) Novel gravel-like $\mathrm{NiMoO}_{4}$ nanoparticles on carbon cloth for outstanding supercapacitor applications. Ceram Int 46:6406-6412. https://doi.org/10.1016/j.ceramint.2019.11.118

Hwang J et al (2019) Tuning perovskite oxides by strain: electronic structure, properties, and functions in (electro)catalysis and ferroelectricity. Mater Today. https://doi.org/10.1016/j.matto d.2019.03.014

Ikkurthi KD et al (2018) Synthesis of nanostructured metal sulfides via a hydrothermal method and their use as an electrode material for supercapacitors. New J Chem 42:19183-19192. https://doi. org/10.1039/C8NJ04358B

Iro ZS et al (2016) A brief review on electrode materials for supercapacitor. Int J Electrochem Sci 11:10628-10643. https://doi. org/10.20964/2016.12.50

Ismail FM et al (2018) Mesoporous spinel manganese zinc ferrite for high-performance supercapacitors. J Electroanal Chem. https:// doi.org/10.1016/j.jelechem.2018.04.002

Israr $\mathrm{M}$ et al (2020) A unique $\mathrm{ZnFe}_{2} \mathrm{O}_{4}$ /graphene nanoplatelets nanocomposite for electrochemical energy storage and efficient visible light driven catalysis for the degradation of organic noxious in wastewater. J Phys Chem Solids 140:109333. https://doi. org/10.1016/j.jpcs.2020.109333

Jain TK et al (2008) Magnetic nanoparticles with dual functional properties: drug delivery and magnetic resonance imaging. Biomaterials 29:4012-4021. https://doi.org/10.1016/j.biomateria 1s.2008.07.004

Jang K et al (2015) Intense pulsed light-assisted facile and agile fabrication of cobalt oxide/nickel cobaltite nanoflakes on nickelfoam for high performance supercapacitor applications. J Alloys Compd 618:227-232. https://doi.org/10.1016/j.jallc om.2014.08.166

Jeevanandam J et al (2018) Review on nanoparticles and nanostructured materials: history, sources, toxicity and regulations. Beilstein J Nanotechnol 9:1050-1074. https://doi.org/10.3762/bjnan 0.9 .98

Jia Y et al (2017) Hierarchical nanosheet-based $\mathrm{MoS}_{2}$ /graphene nanobelts with high electrochemical energy storage performance. J Power Sources 354:1-9. https://doi.org/10.1016/j.jpows our.2017.04.031
Jia $\mathrm{H}$ et al (2019) Controlled synthesis of MOF-derived quadrupleshelled $\mathrm{CoS}_{2}$ hollow dodecahedrons as enhanced electrodes for supercapacitors. Electrochim Acta 312:54-61. https://doi. org/10.1016/j.electacta.2019.04.192

Jiang SP (2019) Development of lanthanum strontium cobalt ferrite perovskite electrodes of solid oxide fuel cells - a review. Int J Hydrog Energy 44:7448-7493. https://doi.org/10.1016/j.ijhyd ene.2019.01.212

Jiang $\mathrm{H}$ et al (2012) Mesoporous carbon incorporated metal oxide nanomaterials as supercapacitor electrodes. Adv Mater 24:41974202. https://doi.org/10.1002/adma.201104942

Jiang J et al (2013) Diffusion-controlled evolution of core-shell nanowire arrays into integrated hybrid nanotube arrays for Li-ion batteries. Nanoscale 5:8105-8113. https://doi.org/10.1039/C3NR0 $1786 \mathrm{~A}$

Jiang Y et al (2016) Nickel silicotungstate-decorated Pt photocathode as an efficient catalyst for triiodide reduction in dye-sensitized solar cells. Dalton Trans 45:16859-16868. https://doi. org/10.1039/C6DT03190K

Jin J et al (2013) Flexible self-supporting graphene-sulfur paper for lithium sulfur batteries. RSC Adv 3:2558-2560. https://doi. org/10.1039/C2RA22808D

Jinlong L et al (2017) Synthesis of $\mathrm{CoMoO}_{4} @$ RGO nanocomposites as high-performance supercapacitor electrodes. Microporous Mesoporous Mater 242:264-270. https://doi.org/10.1016/j.micro meso.2017.01.034

Kandula $S$ et al (2018) Fabrication of a 3D hierarchical sandwich $\mathrm{Co}_{9} \mathrm{~S}_{8} / \alpha-\mathrm{MnS} @ \mathrm{~N}-\mathrm{C} @ \mathrm{MoS}_{2}$ nanowire architectures as advanced electrode material for high performance hybrid supercapacitors. Small 14:1800291. https://doi.org/10.1002/smll.201800291

Kang $C$ et al (2015) Three-dimensional carbon nanotubes for high capacity lithium-ion batteries. J Power Sources 299:465-471. https://doi.org/10.1016/j.jpowsour.2015.08.103

Kathalingam A et al (2020) Nanosheet-like $\mathrm{ZnCo}_{2} \mathrm{O}_{4} @$ nitrogen doped graphene oxide/polyaniline composite for supercapacitor application: effect of polyaniline incorporation. J Alloys Compd 830:154734. https://doi.org/10.1016/j.jallcom.2020.154734

Kaur P, Singh K (2019) Review of perovskite-structure related cathode materials for solid oxide fuel cells. Ceram Int. https://doi. org/10.1016/j.ceramint.2019.11.066

Kazemi SH et al (2016) Binder-free electrodes of $\mathrm{NiMoO}_{4} /$ graphene oxide nanosheets: synthesis, characterization and supercapacitive behavior. RSC Adv 6:111170-111181. https://doi.org/10.1039/ C6RA23076H

Ke Q, Wang J (2016) Graphene-based materials for supercapacitor electrodes-a review. J Materiomics 2:37-54. https://doi. org/10.1016/j.jmat.2016.01.001

Kefeni KK et al (2020) Spinel ferrite nanoparticles and nanocomposites for biomedical applications and their toxicity. Mater Sci Eng, C 107:110314. https://doi.org/10.1016/j.msec.2019.110314

Keränen A et al (2013) Preparation of novel anion exchangers from pine sawdust and bark, spruce bark, birch bark and peat for the removal of nitrate. Chem Eng Sci 98:59-68. https://doi. org/10.1016/j.ces.2013.05.007

Khawula TNY et al (2016) Symmetric pseudocapacitors based on molybdenum disulfide $\left(\mathrm{MoS}_{2}\right)$-modified carbon nanospheres: correlating physicochemistry and synergistic interaction on energy storage. J Mater Chem A 4:6411-6425. https://doi. org/10.1039/C6TA00114A

Kim TW et al (2014) Electrochemical synthesis of spinel type $\mathrm{ZnCo}_{2} \mathrm{O}_{4}$ electrodes for use as oxygen evolution reaction catalysts. J Phys Chem Lett 5:2370-2374. https://doi.org/10.1021/jz501077u

$\mathrm{Kim} \mathrm{HJ}$ et al (2016) Densely packed zinc sulfide nanoparticles on $\mathrm{TiO}_{2}$ for hindering electron recombination in dye-sensitized solar cells. New J Chem 40:9176-9186. https://doi.org/10.1039/ C6NJ02493A 
Kim DY et al (2017) Chemical synthesis of hierarchical $\mathrm{NiCo}_{2} \mathrm{~S}_{4}$ nanosheets like nanostructure on flexible foil for a high performance supercapacitor. Sci Rep 7:1-10. https://doi.org/10.1038/ s41598-017-10218-z

Koneracká M et al (1999) Immobilization of proteins and enzymes to fine magnetic particles. J Magn Magn Mater 201:427-430. https ://doi.org/10.1016/S0304-8853(99)00005-0

Kumar TP et al (2004) Tin-filled carbon nanotubes as insertion anode materials for lithium-ion batteries. Electrochem Commun 6:520 525. https://doi.org/10.1016/j.elecom.2004.03.009

Kumar PR et al (2014) Enhanced properties of porous $\mathrm{CoFe}_{2} \mathrm{O}_{4}$-reduced graphene oxide composites with alginate binders for $\mathrm{Li}$-ion battery applications. New J Chem 38:3654-3661. https://doi. org/10.1039/C4NJ00419A

Kumar YA et al (2020) $\mathrm{A} \mathrm{MoNiO}_{4}$ flower-like electrode material for enhanced electrochemical properties via a facile chemical bath deposition method for supercapacitor applications. New J Chem 44:522-529. https://doi.org/10.1039/C9NJ05529K

Kumuthini R et al (2017) Electrochemical properties of electrospun $\mathrm{MoS}_{2} @ \mathrm{C}$ nanofiber as electrode material for high-performance supercapacitor application. J Alloys Compd 705:624-630. https ://doi.org/10.1016/j.jallcom.2017.02.163

Kwon J et al (2017) Facile hydrothermal synthesis of cubic spinel $\mathrm{AB}_{2} \mathrm{O}_{4}$ type $\mathrm{MnFe}_{2} \mathrm{O}_{4}$ nanocrystallites and their electrochemical performance. Appl Surf Sci 413:83-91. https://doi.org/10.1016/j. apsusc.2017.04.022

Lacerda GRBS et al (2020) Development of nanohybrids based on carbon nanotubes/P(EDOT-co-MPy) and P(EDOT-co-PyMP) copolymers as electrode materials for aqueous supercapacitors. Electrochim Acta 335:135637. https://doi.org/10.1016/j.elect acta.2020.135637

Lalwani S et al (2019) Layered nanoblades of iron cobaltite for high performance asymmetric supercapacitors. Appl Surf Sci 476:1025-1034. https://doi.org/10.1016/j.apsusc.2019.01.184

Lamberti A (2018) Flexible supercapacitor electrodes based on $\mathrm{MoS}_{2}$-intercalated rGO membranes on Ti mesh. Mater Sci Semicond Process 73:106-110. https://doi.org/10.1016/j. mssp.2017.06.046

Lang $X$ et al (2017) Supercapacitor performance of perovskite $\mathrm{La}_{1-\mathrm{x}} \mathrm{Sr}_{\mathrm{x}} \mathrm{MnO}_{3}$. Dalton Trans 46:13720-13730. https://doi. org/10.1039/C7DT03134C

Lang $X$ et al (2019) Ag nanoparticles decorated perovskite $\mathrm{La}_{0.85} \mathrm{Sr}_{0.15} \mathrm{MnO}_{3}$ as electrode materials for supercapacitors. Mater Lett 243:34-37. https://doi.org/10.1016/j.matle t.2019.02.002

Lavela P et al (2009) ${ }^{57} \mathrm{Fe}$ Mossbauer spectroscopy study of the electrochemical reaction with lithium of $\mathrm{MFe}_{2} \mathrm{O}_{4}(\mathrm{M}=\mathrm{Co}$ and $\mathrm{Cu}$ ) electrodes. J Phys Chem C 113:20081-20087. https://doi. org/10.1021/jp9056362

Lee HI et al (2011) Spontaneous phase separation mediated synthesis of 3D mesoporous carbon with controllable cage and window size. Adv Mater 23:2357-2361. https://doi.org/10.1002/ adma.201003599

Lee H et al (2017) Yolk-shell polystyrene@ microporous organic network: a smart template with thermally disassemblable yolk to engineer hollow $\mathrm{MoS}_{2} / \mathrm{C}$ composites for high-performance supercapacitors. ACS Omega 2:7658-7665. https://doi.org/10.1021/ acsomega.7b01426

Li X et al (2015) Fabrication of $\gamma$-MnS/rGO composite by facile onepot solvothermal approach for supercapacitor applications. $\mathbf{J}$ Power Sources 282:194-201. https://doi.org/10.1016/j.jpows our.2015.02.057

Li Z et al (2016a) Flaky $\mathrm{CoS}_{2}$ and graphene nanocomposite anode materials for sodium-ion batteries with improved performance. RSC Adv 6:70632-70637. https://doi.org/10.1039/C6RA12563H
Li L et al (2016b) Hierarchical carbon@ $\mathrm{Ni}_{3} \mathrm{~S}_{2} @ \mathrm{MoS}_{2}$ double coreshell nanorods for high-performance supercapacitors. J Mater Chem A 4:1319-1325. https://doi.org/10.1039/c5ta08714g

$\mathrm{Li} \mathrm{M}$ et al (2016c) Ultrafine jagged platinum nanowires enable ultrahigh mass activity for the oxygen reduction reaction. Science 354:1414-1419. https://doi.org/10.1126/science.aaf9050

Li W et al (2016d) Mesoporous materials for energy conversion and storage devices. Nat Rev Mater 1:1-17. https://doi.org/10.1038/ natrevmats.2016.23

Li Z et al (2017a) Controlled synthesis of perovskite lanthanum ferrite nanotubes with excellent electrochemical properties. RSC Adv 7:12931-12937. https://doi.org/10.1039/C6RA27423D

Li X et al (2017b) Supercapacitor electrode materials with hierarchically structured pores from carbonization of MWCNTs and ZIF-8 composites. Nanoscale 9:2178-2187. https://doi.org/10.1039/ C6NR08987A

Li P et al (2018) Stretchable all-gel-state fiber-shaped supercapacitors enabled by macromolecularly interconnected 3D graphene/ nanostructured conductive polymer hydrogels. Adv Mater 30:1800124. https://doi.org/10.1002/adma.201800124

$\mathrm{Li} \mathrm{H}$ et al (2019a) Zinc cobalt sulfide nanoparticles as high performance electrode material for asymmetric supercapacitor. Electrochim Acta 319:716-726. https://doi.org/10.1016/j.elect acta.2019.07.033

Li J et al (2019b) Dielectric, multiferroic and magnetodielectric properties of $(1-\mathrm{x}) \mathrm{BaTiO}_{3}-\mathrm{xSr}_{2} \mathrm{CoMoO}_{6}$ solid solution. Ceram Int 45:16353-16360. https://doi.org/10.1016/j.ceramint.2019.05.163

Li J et al (2019c) Cladding nanostructured AgNWs-MoS $\mathrm{S}_{2}$ electrode material for high-rate and long-life transparent in-plane microsupercapacitor. Energy Storage Mater 16:212-219. https://doi. org/10.1016/j.ensm.2018.05.013

Li D et al (2019d) A general self-template-etched solution route for the synthesis of 2D $\gamma$-manganese sulfide nanoplates and their enhanced supercapacitive performance. New J Chem 43:4674 4680. https://doi.org/10.1039/c8nj06143b

Li Y et al (2019e) Bark-based 3D porous carbon nanosheet with ultrahigh surface area for high performance supercapacitor electrode material. ACS Sustain Chem Eng 7:13827-13835. https://doi. org/10.1021/acssuschemeng.9b01779

$\mathrm{Li} \mathrm{T}$ et al (2020) Advances in transition-metal ( $\mathrm{Zn}, \mathrm{Mn}, \mathrm{Cu}$ )-based MOFs and their derivatives for anode of lithium-ion batteries. Coord Chem Rev 410:213221. https://doi.org/10.1016/j. ccr.2020.213221

Lian M et al (2017) Hydrothermal synthesis of polypyrrole/MoS intercalation composites for supercapacitor electrodes. Ceram Int 43:9877-9883. https://doi.org/10.1016/j.ceramint.2017.04.171

Liang A et al (2018) Robust flexible WS $\mathrm{W}_{2}$ PEDOT:PSS film for use in high-performance miniature supercapacitors. J Electroanal Chem 824:136-146. https://doi.org/10.1016/j.jelechem.2018.07.040

Liang G et al (2020) Developing high-voltage spinel LiNi0.5Mn1.5O4 cathodes for high-energy-density lithium-ion batteries: current achievements and future prospects. J Mater Chem. https://doi. org/10.1039/D0TA02812F

Lin L-Y, Lin L-Y (2017) Material effects on the electrocapacitive performance for the energy-storage electrode with nickel cobalt oxide core/shell nanostructures. Electrochim Acta 250:335-347. https://doi.org/10.1016/j.electacta.2017.08.074

Lin Y-P, Wu N-L (2011) Characterization of $\mathrm{MnFe}_{2} \mathrm{O}_{4} / \mathrm{LiMn}_{2} \mathrm{O}_{4}$ aqueous asymmetric supercapacitor. J Power Sources 196:851-854. https://doi.org/10.1016/j.jpowsour.2010.07.066

Lin Y et al (2013) Graphene/semiconductor heterojunction solar cells with modulated antireflection and graphene work function. Energy Environ Sci 6:108-115. https://doi.org/10.1039/C2EE2 $3538 \mathrm{~B}$

Lin T-W et al (2018) Ternary composite nanosheets with $\mathrm{MoS}_{2} / \mathrm{WS}_{2} /$ graphene heterostructures as high-performance cathode materials 
for supercapacitors. ChemElectroChem 5:1024-1031. https://doi. org/10.1002/celc. 201800043

Liu $\mathrm{Z}$ et al (2005) A phenol biosensor based on immobilizing tyrosinase to modified core-shell magnetic nanoparticles supported at a carbon paste electrode. Anal Chim Acta 533:3-9. https://doi. org/10.1016/j.aca.2004.10.077

Liu JW et al (2007) Magnetic and electric properties of the colossal magnetoresistance manganite $\mathrm{Sm}_{1.4} \mathrm{Sr}_{1.2} \mathrm{Ca}_{0.4} \mathrm{Mn}_{2} \mathrm{O}_{7}$. Solid State Commun 141:341-343. https://doi.org/10.1016/j. ssc.2006.11.004

Liu X et al (2012) Nanostructure-based $\mathrm{WO}_{3}$ photoanodes for photoelectrochemical water splitting. Phys Chem Chem Phys 14:78947911. https://doi.org/10.1039/C2CP40976C

Liu M-C et al (2013a) Facile synthesis of $\mathrm{NiMoO}_{4} \cdot \mathrm{xH}_{2} \mathrm{O}$ nanorods as a positive electrode material for supercapacitors. Rsc Adv 3:6472-6478. https://doi.org/10.1039/C3RA22993A

Liu M-C et al (2013b) Facile fabrication of $\mathrm{CoMoO}_{4}$ nanorods as electrode material for electrochemical capacitors. Mater Lett 94:197-200. https://doi.org/10.1016/j.matlet.2012.12.057

Liu S et al (2016a) Vertically stacked bilayer $\mathrm{CuCo}_{2} \mathrm{O}_{4} / \mathrm{MnCo}_{2} \mathrm{O}_{4}$ heterostructures on functionalized graphite paper for high-performance electrochemical capacitors. J Mater Chem A 4:80618071. https://doi.org/10.1039/C6TA00960C

Liu Y et al (2016b) Design of perovskite oxides as anion-intercalationtype electrodes for supercapacitors: cation leaching effect. ACS Appl Mater Interfaces 8:23774-23783. https://doi.org/10.1021/ acsami.6b08634

Liu Y et al (2016c) Design, synthesis, and energy-related applications of metal sulfides. Mater Horiz 3:402-421. https://doi. org/10.1039/C6MH00075D

Liu P et al (2017a) A high-performance electrode for supercapacitors: silver nanoparticles grown on a porous perovskite-type material $\mathrm{La}_{0.7} \mathrm{Sr}_{0.3} \mathrm{CoO}_{3-\delta}$ substrate. Chem Eng J 328:1-10. https://doi. org/10.1016/j.cej.2017.06.150

Liu C et al (2017b) 3D porous nanoarchitectures derived from SnS/Sdoped graphene hybrid nanosheets for flexible all-solid-state supercapacitors. Small 13:1603494. https://doi.org/10.1002/ smll.201603494

Liu W et al (2018a) Ternary transition metal sulfides embedded in graphene nanosheets as both the anode and cathode for highperformance asymmetric supercapacitors. Chem Mater 30(10551068):10. https://doi.org/10.1021/acs.chemmater.7b04976

Liu $\mathrm{S}$ et al (2018b) Effect of cation substitution on the pseudocapacitive performance of spinel cobaltite $\mathrm{MCo}_{2} \mathrm{O}_{4}(\mathrm{M}=\mathrm{Mn}, \mathrm{Ni}, \mathrm{Cu}$, and Co). J Mater Chem A 6:10674-10685. https://doi.org/10.1039/ C8TA00540K

Liu Y et al (2018c) Highly defective layered double perovskite oxide for efficient energy storage via reversible pseudocapacitive oxygen-anion intercalation. Adv Energy Mater 8:1702604. https:// doi.org/10.1002/aenm.201702604

Liu W et al (2018d) Synthesis of dense $\mathrm{MoS}_{2}$ nanosheet layers on hollow carbon spheres and their applications in supercapacitors and the electrochemical hydrogen evolution reaction. Inorg Chem Front 5:2198-2204. https://doi.org/10.1039/c8qi00562a

Liu MC et al (2018e) Electrostatically charged $\mathrm{MoS}_{2} /$ graphene oxide hybrid composites for excellent electrochemical energy storage devices. ACS Appl Mater Interfaces 10:35571-35579. https:// doi.org/10.1021/acsami.8b09085

Liu $\mathrm{H}$ et al (2018f) $\mathrm{CuS} / \mathrm{MnS}$ composite hexagonal nanosheet clusters: synthesis and enhanced pseudocapacitive properties. Electrochim Acta 271:425-432. https://doi.org/10.1016/j.elect acta.2018.03.048

Liu S et al (2018g) Large-scale synthesis of porous carbon via onestep $\mathrm{CuCl}_{2}$ activation of rape pollen for high-performance supercapacitors. J Mater Chem A 6:12046-12055. https://doi. org/10.1039/C8TA02838A
Liu Q et al (2019) 3D sandwiched nanosheet of $\mathrm{MoS}_{2} / \mathrm{C} @ \mathrm{RGO}$ achieved by supramolecular self-assembly method as high performance material in supercapacitor. J Alloys Compd 777:11761183. https://doi.org/10.1016/j.jallcom.2018.11.108

Liu $\mathrm{Y}$ et al (2020) Activation-free supercapacitor electrode based on surface-modified $\mathrm{Sr}_{2} \mathrm{CoMo}_{1-\mathrm{x}} \mathrm{Ni}_{\mathrm{x}} \mathrm{O}_{6-\delta}$ perovskite. Chem Eng J 390:124645. https://doi.org/10.1016/j.cej.2020.124645

Louca D et al (1997) Local Jahn-Teller distortion in $\mathrm{La}_{1-\mathrm{x}} \mathrm{Sr}_{\mathrm{x}} \mathrm{MnO}_{3}$ observed by pulsed neutron diffraction. Phys Rev B 56:R8475. https://doi.org/10.1103/PhysRevB.56.R8475

Lu Y et al (2017) Nanowire-assembled $\mathrm{Co}_{3} \mathrm{O}_{4} @ \mathrm{NiCo}_{2} \mathrm{O}_{4}$ architectures for high performance all-solid-state asymmetric supercapacitors. J Mater Chem A 5:24981-24988. https://doi.org/10.1039/C7TA0 $6437 \mathrm{C}$

Lü J et al (2015) A preliminary study of the pseudo-capacitance features of strontium doped lanthanum manganite. RSC Adv 5:5858-5862. https://doi.org/10.1039/C4RA13583K

Luo B et al (2012) Chemical approaches toward graphene-based nanomaterials and their applications in energy-related areas. Small 8:630-646. https://doi.org/10.1002/smll.201101396

Luo $\mathrm{Y}$ et al (2015) Aligned carbon nanotube/molybdenum disulfide hybrids for effective fibrous supercapacitors and lithium ion batteries. J Mater Chem A 3:17553-17557. https://doi.org/10.1039/ C5TA04457J

Luo $\mathrm{W}$ et al (2017) One-step extended strategy for the ionic liquidassisted synthesis of $\mathrm{Ni}_{3} \mathrm{~S}_{4}-\mathrm{MoS}_{2}$ heterojunction electrodes for supercapacitors. J Mater Chem A 5:11278-11285. https://doi. org/10.1039/c7ta02268a

Luo W et al (2018) One-pot synthesis of highly stable carbon- $\mathrm{MoS}_{2}$ nanosphere electrodes using a co-growth mechanism for supercapacitors. New J Chem 42:10111-10117. https://doi.org/10.1039/ c8nj01387j

Lv Y et al (2017) Balanced mesoporous nickle cobaltite-graphene and doped carbon electrodes for high-performance asymmetric supercapacitor. Chem Eng J 326:401-410. https://doi.org/10.1016/j. cej.2017.05.167

Ma L et al (2015) Molybdenum-doped few-layered $\mathrm{SnS}_{2}$ architectures with enhanced electrochemical supercapacitive performance. RSC Adv 5:105862-105868. https://doi.org/10.1039/c5ra18634j

$\mathrm{Ma} \mathrm{Y}$ et al (2017) One-pot synthesis of hierarchical $\mathrm{Bi}_{2} \mathrm{~S}_{3}-\mathrm{MoS}_{2}$ nanosheet array with high electrochemical performance. J Power Sources 342:921-928. https://doi.org/10.1016/j.jpows our.2017.01.020

Ma P et al (2019a) Flexible supercapacitor electrodes based on carbon cloth-supported $\mathrm{LaMnO}_{3} / \mathrm{MnO}$ nano-arrays by one-step electrodeposition. Nanomaterials 9:1676. https://doi.org/10.3390/nano9 121676

Ma J et al (2019b) Conducting polymers based composite electrode materials in supercapacitor application. IOP Conf Ser Earth Environ Sci 267:042047. https://doi.org/10.1088/1755$1315 / 267 / 4 / 042047$

Ma PP et al (2020) Effect of A-site substitution by $\mathrm{Ca}$ or $\mathrm{Sr}$ on the structure and electrochemical performance of $\mathrm{LaMnO}_{3}$ perovskite. Electrochim Acta 332:135489. https://doi.org/10.1016/j. electacta.2019.135489

Magrez A et al (2006) Growth of single-crystalline $\mathrm{KNbO}_{3}$ nanostructures. J Phys Chem B 110:58-61. https://doi.org/10.1021/jp053 $800 \mathrm{a}$

Mahmood N et al (2014) Graphene-based nanocomposites for energy storage and conversion in lithium batteries, supercapacitors and fuel cells. J Mater Chem A 2:15-32. https://doi.org/10.1039/ C3TA13033A

Mai L-Q et al (2011a) Hierarchical $\mathrm{MnMoO}_{4} / \mathrm{CoMoO}_{4}$ heterostructured nanowires with enhanced supercapacitor performance. Nat Commun 2:1-5. https://doi.org/10.1038/ncomms1387 
Mai L-Q et al (2011b) Hierarchical $\mathrm{MnMoO}_{4} / \mathrm{CoMoO}_{4}$ heterostructured nanowires with enhanced supercapacitor performance. Nat Commun 2:381. https://doi.org/10.1038/ncomms1387

Majumder M et al (2017) Gravimetric and volumetric capacitive performance of polyindole/carbon black/MoS $\mathrm{S}_{2}$ hybrid electrode material for supercapacitor applications. Electrochim Acta 248:98-111. https://doi.org/10.1016/j.electacta.2017.07.107

Maksoud MA et al (2020a) Influence of $\mathrm{Mg}^{2+}$ substitution on structural, optical, magnetic, and antimicrobial properties of $\mathrm{Mn}-\mathrm{Zn}$ ferrite nanoparticles. J Mater Sci: Mater Electron. https://doi. org/10.1007/s10854-019-02799-4

Maksoud MA et al (2020b) $\mathrm{La}^{3+}$ doped $\mathrm{LiCo}_{0.25} \mathrm{Zn}_{0.25} \mathrm{Fe}_{2} \mathrm{O}_{4}$ spinel ferrite nanocrystals: insights on structural, optical, and magnetic properties. J Rare Earths. https://doi.org/10.1016/j. jre.2019.12.017

Manuraj $\mathrm{M}$ et al (2020) Heterostructured $\mathrm{MoS}_{2}-\mathrm{RuO}_{2}$ nanocomposite: a promising electrode material for supercapacitors. J Alloys Compd 836:155420. https://doi.org/10.1016/j.jallc om. 2020.155420

Mariappan CR et al (2019) Synthesis and electrochemical properties of $\mathrm{rGO} /$ polypyrrole/ferrites nanocomposites obtained via a hydrothermal route for hybrid aqueous supercapacitors. J Electroanal Chem 845:72-83. https://doi.org/10.1016/j.jelec hem.2019.05.031

Masala O, Seshadri R (2004) Synthesis routes for large volumes of nanoparticles. Annu Rev Mater Res 34:41-81. https://doi. org/10.1146/annurev.matsci.34.052803.090949

Masikhwa TM et al (2017) High performance asymmetric supercapacitor based on molybdenum disulphide/graphene foam and activated carbon from expanded graphite. J Colloid Interface Sci 488:155-165. https://doi.org/10.1016/j.jcis.2016.10.095

Mefford JT et al (2014) Anion charge storage through oxygen intercalation in $\mathrm{LaMnO}_{3}$ perovskite pseudocapacitor electrodes. Nat Mater 13:726-732. https://doi.org/10.1038/nmat4000

Mehrez JA-A et al (2019) Hierarchical $\mathrm{MnCo}_{2} \mathrm{O}_{4} @ \mathrm{NiMoO}_{4}$ as freestanding core-shell nanowire arrays with synergistic effect for enhanced supercapacitor performance. Inorg Chem Front 6:857865. https://doi.org/10.1039/C8QI01420E

Meng Q et al (2014) High-performance all-carbon yarn micro-supercapacitor for an integrated energy system. Adv Mater 26:41004106. https://doi.org/10.1002/adma.201400399

Miller JR, Simon P (2008) Electrochemical capacitors for energy management. Science 321:651-652. https://doi.org/10.1126/scien ce. 1158736

Minakshi M et al (2017) Rescaling metal molybdate nanostructures with biopolymer for energy storage having high capacitance with robust cycle stability. Dalton Trans 46:3588-3600. https://doi. org/10.1039/C7DT00139H

Mishra RK et al (2017) One-step solvothermal synthesis of carnation flower-like $\mathrm{SnS}_{2}$ as superior electrodes for supercapacitor applications. Appl Surf Sci 425:923-931. https://doi.org/10.1016/j. apsusc.2017.07.045

Mishra RK et al (2019) Vertical-slate-like $\mathrm{MoS}_{2}$ nanostructures on 3D-Ni-foam for binder-free, low-cost, and scalable solid-state symmetric supercapacitors. Curr Appl Phys 19:1-7. https://doi. org/10.1016/j.cap.2018.10.011

Mo $\mathrm{H}$ et al (2018) Influence of calcium doping on performance of $\mathrm{LaMnO}_{3}$ supercapacitors. Ceram Int 44:9733-9741. https://doi. org/10.1016/j.ceramint.2018.02.205

Modeshia DR, Walton RI (2010) Solvothermal synthesis of perovskites and pyrochlores: crystallisation of functional oxides under mild conditions. Chem Soc Rev 39:4303-4325. https://doi. org/10.1039/B904702F

Mousa MA et al (2017) Nanostructured ferrite/graphene/polyaniline using for supercapacitor to enhance the capacitive behavior. J
Solid State Electrochem 21:995-1005. https://doi.org/10.1007/ s10008-016-3446-6

Muniraj VKA et al (2020) Flexible energy storage device based on poly(N-phenylglycine), an incentive-energy pseudocapacitive conducting polymer, and electrochemically exfoliated graphite sheets. ACS Sustain Chem Eng. https://doi.org/10.1021/acssu schemeng.0c00880

Murugan M et al (2017) Synthesis and property studies of molybdenum disulfide modified reduced graphene oxide $\left(\mathrm{MoS}_{2}-\mathrm{rGO}\right)$ nanocomposites for supercapacitor applications. J Nanosci Nanotechnol 17:5469-5474. https://doi.org/10.1166/jnn.2017.13845

Najib S, Erdem E (2019) Current progress achieved in novel materials for supercapacitor electrodes: mini review. Nanoscale Adv 1:2817-2827. https://doi.org/10.1039/C9NA00345B

Nam HW et al (2020) Binder-free honeycomb-like $\mathrm{FeMoO}_{4}$ nanosheet arrays with dual properties of both battery-type and pseudocapacitive-type performances for supercapacitor applications. J Energy Storage 27:101055. https://doi.org/10.1016/j.est.2019.101055

$\mathrm{Nan} \mathrm{H}-\mathrm{S}$ et al (2019) Recent advances in perovskite oxides for anionintercalation supercapacitor: a review. Mater Sci Semicond Process 94:35-50. https://doi.org/10.1016/j.mssp.2019.01.033

Nandi DK et al (2017) Highly uniform atomic layer-deposited $\mathrm{MoS}_{2} @ 3 \mathrm{D}-\mathrm{Ni}$-foam: a novel approach to prepare an electrode for supercapacitors. ACS Appl Mater Interfaces 9:40252-40264. https://doi.org/10.1021/acsami.7b12248

Nandy A et al (2017) Alteration of magnetic behavior and microstructural distortion of $\mathrm{EuMnO}_{3}$ by partial substitution of Eu with monovalent Na. J Alloys Compd 715:214-223. https://doi. org/10.1016/j.jallcom.2017.04.278

Naveenkumar P, Paruthimal Kalaignan G (2018) Electrodeposited $\mathrm{MnS}$ on graphene wrapped Ni-foam for enhanced supercapacitor applications. Electrochim Acta 289:437-447. https://doi. org/10.1016/j.electacta.2018.09.100

Niu X et al (2017) Influence of $\mathrm{Sn}^{4+}$-substituted on the magnetic properties and power loss of $\mathrm{Ni}-\mathrm{Zn}$ soft magnetic ferrites. Opt-Int J Light Electron Opt 134:135-139. https://doi.org/10.1016/j.ijleo .2017 .01 .043

Nocera DG (2009) Living healthy on a dying planet. Chem Soc Rev 38:13-15. https://doi.org/10.1039/B820660K

O'handley RC (2000) Modern magnetic materials: principles and applications. Wiley, Hoboken

Omar FS et al (2017) Binary composite of polyaniline/copper cobaltite for high performance asymmetric supercapacitor application. Electrochim Acta 227:41-48. https://doi.org/10.1016/j.elect acta.2017.01.006

Osman AI (2020) Mass spectrometry study of lignocellulosic biomass combustion and pyrolysis with $\mathrm{NO}_{\mathrm{x}}$ removal. Renew Energy 146:484-496. https://doi.org/10.1016/j.renene.2019.06.155

Osman AI et al (2018) A highly active and synergistic $\mathrm{Pt} / \mathrm{Mo}_{2} \mathrm{C} / \mathrm{Al}_{2} \mathrm{O}_{3}$ catalyst for water-gas shift reaction. Mol Catal 455:38-47. https ://doi.org/10.1016/j.mcat.2018.05.025

Osman AI et al (2019a) Production and characterisation of activated carbon and carbon nanotubes from potato peel waste and their application in heavy metal removal. Environ Sci Pollut Res 26:37228-37241. https://doi.org/10.1007/s11356-019-06594-w

Osman AI et al (2019b) Reusing, recycling and up-cycling of biomass: a review of practical and kinetic modelling approaches. Fuel Process Technol 192:179-202. https://doi.org/10.1016/j. fuproc.2019.04.026

Osman AI et al (2020a) Upcycling brewer's spent grain waste into activated carbon and carbon nanotubes for energy and other applications via two-stage activation. J Chem Technol Biotechnol 95:183-195. https://doi.org/10.1002/jctb.6220

Osman AI et al (2020b) The production and application of carbon nanomaterials from high alkali silicate herbaceous biomass. Sci Rep 10:2563. https://doi.org/10.1038/s41598-020-59481-7 
Ouaissa S et al (2015) Magnetization study of cobalt ferrite by mean field approximation. Phys Procedia 75:792-801. https://doi. org/10.1016/j.phpro.2015.12.103

Palaniyandy $\mathrm{N}$ et al (2019) Conversion of electrolytic $\mathrm{MnO}_{2}$ to $\mathrm{Mn}_{3} \mathrm{O}_{4}$ nanowires for high-performance anode materials for lithiumion batteries. J Electroanal Chem 833:79-92. https://doi. org/10.1016/j.jelechem.2018.11.002

Palsaniya S et al (2018) Synthesis of polyaniline/graphene/MoS 2 nanocomposite for high performance supercapacitor electrode. Polymer 150:150-158. https://doi.org/10.1016/j.polymer.2018.07.018

Pan L, Zhu G (2016) Perovskite materials: synthesis, characterisation, properties, and applications. Books Demand. https://doi. org/10.5772/60469

Pan A et al (2013) Template-free synthesis of $\mathrm{VO}_{2}$ hollow microspheres with various interiors and their conversion into $\mathrm{V}_{2} \mathrm{O}_{5}$ for lithiumion batteries. Angew Chem Int Ed 52:2226-2230. https://doi. org/10.1002/ange.201209535

Park C-M et al (2010) Li-alloy based anode materials for Li secondary batteries. Chem Soc Rev 39:3115-3141. https://doi.org/10.1039/ B919877F

Parveen N et al (2018) Facile synthesis of $\mathrm{SnS}_{2}$ nanostructures with different morphologies for high-performance supercapacitor applications. ACS Omega 3:1581-1588. https://doi.org/10.1021/ acsomega.7b01939

Patil S et al (2016) Investigation of magnesium substituted nano particle zinc ferrites for relative humidity sensors. Sens Actuators, A 244:35-43. https://doi.org/10.1016/j.sna.2016.04.019

Patil J et al (2018) Spinel $\mathrm{MgFe}_{2} \mathrm{O}_{4}$ thick films: a colloidal approach for developing gas sensors. Mater Lett 213:27-30. https://doi. org/10.1016/j.matlet.2017.11.009

Pazhamalai P et al (2019) Copper tungsten sulfide anchored on Nifoam as a high-performance binder free negative electrode for asymmetric supercapacitor. Chem Eng J 359:409-418. https:// doi.org/10.1016/j.cej.2018.11.153

Pedro-García F et al (2019) Multiferroic properties of nanostructured $\mathrm{BiFeO}_{3}$ tailored by milling and sintering by SPS. J Alloys Compd 792:694-701. https://doi.org/10.1016/j.jallcom.2019.04.106

Pendashteh A et al (2015) Nanostructured porous wires of iron cobaltite: novel positive electrode for high-performance hybrid energy storage devices. J Mater Chem A 3:16849-16859. https://doi. org/10.1039/C5TA02701B

Perumal RN et al (2019) Structural, dielectric, AC conductivity, piezoelectric and impedance spectroscopy studies on $\mathrm{PbZr}_{0.52} \mathrm{Ti}_{0.48} \mathrm{O}_{3}: \mathrm{RE}^{3+}\left(\mathrm{RE}^{3+}: \mathrm{La}^{3+}, \mathrm{Nd}^{3+}\right.$ and $\left.\mathrm{Dy}^{3+}\right)$ ceramics. Results Phys 15:102729. https://doi.org/10.1016/j. rinp.2019.102729

Pham DT et al (2018) Facile synthesis of pyrite $\left(\mathrm{FeS}_{2} / \mathrm{C}\right)$ nanoparticles as an electrode material for non-aqueous hybrid electrochemical capacitors. Nanoscale 10:5938-5949. https://doi.org/10.1039/ C7NR06352K

Poizot P et al (2000) Nano-sized transition-metal oxides as negativeelectrode materials for lithium-ion batteries. Nature 407:496. https://doi.org/10.1038/35035045

Pontes DSL et al (2017) Combined theoretical and nanoscale experimental study of $\mathrm{Pb}(\mathrm{Ca}, \mathrm{Ba}) \mathrm{TiO}_{3}, \mathrm{~Pb}(\mathrm{Sr}, \mathrm{Ba}) \mathrm{TiO}_{3}$, and $\mathrm{Pb}(\mathrm{Sr}, \mathrm{Ca})$ $\mathrm{TiO}_{3}$ complex perovskite structures: an investigation of the ferroelectric and electronic properties. J Alloys Compd 702:327-337. https://doi.org/10.1016/j.jallcom.2017.01.250

Pope MA et al (2013) Supercapacitor electrodes produced through evaporative consolidation of graphene oxide-water-ionic liquid gels. J Electrochem Soc 160:A1653-A1660

Pour SA et al (2017) Carboxymethyl cellulose (CMC)-loaded $\mathrm{Co}-\mathrm{Cu}$ doped manganese ferrite nanorods as a new dual-modal simultaneous contrast agent for magnetic resonance imaging and nanocarrier for drug delivery system. J Magn Magn Mater 438:85-94. https://doi.org/10.1016/j.jmmm.2017.04.069
Qiang Z et al (2017) Generalized synthesis of a family of highly heteroatom-doped ordered mesoporous carbons. Chem Mater 29:10178-10186. https://doi.org/10.1021/acs.chemmater.7b040 61

Qiao $\mathrm{H}$ et al (2018) Fabrication of PANI-coated $\mathrm{ZnFe}_{2} \mathrm{O}_{4}$ nanofibers with enhanced electrochemical performance for energy storage. Electrochim Acta 273:282-288. https://doi.org/10.1016/j.elect acta.2018.04.010

Qin Q et al (2017) Flexible supercapacitors based on solid ion conducting polymer with high mechanical strength. J Electrochem Soc 164:A1952-A1957. https://doi.org/10.1149/2.0771709jes

Qin $\mathrm{S}$ et al (2018) $\mathrm{MoS}_{2} / \mathrm{Ni}_{3} \mathrm{~S}_{4}$ composite nanosheets on interconnected carbon shells as an excellent supercapacitor electrode architecture for long term cycling at high current densities. Appl Surf Sci 440:741-747. https://doi.org/10.1016/j.apsusc.2018.01.266

Quan H et al (2016) One-pot synthesis of $\alpha$-MnS/nitrogen-doped reduced graphene oxide hybrid for high-performance asymmetric supercapacitors. Electrochim Acta 210:557-566. https://doi. org/10.1016/j.electacta.2016.05.031

Raghu MS et al (2018) Fabrication of polyaniline-few-layer $\mathrm{MoS}_{2}$ nanocomposite for high energy density supercapacitors. Polym Bull 75:4359-4375. https://doi.org/10.1007/s00289-017-2267-9

Ramachandran T, Hamed F (2018) Electrochemical performance of plate-like zinc cobaltite electrode material for supercapacitor applications. J Phys Chem Solids 121:93-101. https://doi. org/10.1016/j.jpcs.2018.04.044

Ramadevi P et al (2020) Structural and electrochemical investigation on pure and aluminium doped nickel ferrite nanoparticles for supercapacitor application. Mater Today Proc. https://doi. org/10.1016/j.matpr.2020.02.888

Ramos-Sanchez JE et al (2020) Sustainable synthesis of AgNPs/ strontium-titanate-perovskite-like catalysts for the photocatalytic production of hydrogen. Catal Today 341:112-119. https://doi. org/10.1016/j.cattod.2019.08.020

Rana DK et al (2020) Development of organic-inorganic flexible PVDF- $\mathrm{LaFeO}_{3}$ nanocomposites for the enhancement of electrical, ferroelectric and magnetic properties. Mater Chem Phys 242:122491. https://doi.org/10.1016/j.matchemphys.2019.12249 1

Ranganatha S, Munichandraiah N (2018) $\gamma$-MnS nanoparticles anchored reduced graphene oxide: electrode materials for high performance supercapacitors. J Sci Adv Mater Dev 3:359-365. https://doi.org/10.1016/j.jsamd.2018.07.001

Rao SS (2020) Synthesis of CNTs on $\mathrm{ZnO} / \mathrm{NiS}$ composite as an advanced electrode material for high-performance supercapacitors. J Energy Storage 28:101199. https://doi.org/10.1016/j. est.2020.101199

Raut SS, Sankapal BR (2016) First report on synthesis of $\mathrm{ZnFe}_{2} \mathrm{O}_{4}$ thin film using successive ionic layer adsorption and reaction: approach towards solid-state symmetric supercapacitor device. Electrochim Acta 198:203-211. https://doi.org/10.1016/j.elect acta.2016.03.059

Ravi S, Senthilkumar C (2017) Low temperature ferromagnetism in $\mathrm{Bi}_{2} \mathrm{MnMoO}_{6}$ double perovskite material. J Alloys Compd 699:463-467. https://doi.org/10.1016/j.jallcom.2016.12.380

Reddy DHK, Yun Y-S (2016) Spinel ferrite magnetic adsorbents: alternative future materials for water purification? Coord Chem Rev 315:90-111. https://doi.org/10.1016/j.ccr.2016.01.012

Reddy MV et al (2013) Metal oxides and oxysalts as anode materials for Li ion batteries. Chem Rev 113:5364-5457. https://doi. org/10.1021/cr3001884

Reddy AE et al (2018a) Construction of novel nanocomposite ZnO@ $\mathrm{CoFe}_{2} \mathrm{O}_{4}$ microspheres grown on nickel foam for high performance electrochemical supercapacitors. Anal Methods 10:223229. https://doi.org/10.1039/C7AY02176C 
Reddy AE et al (2018b) $\mathrm{NiMoO}_{4} @ \mathrm{NiWO}_{4}$ honeycombs as a high performance electrode material for supercapacitor applications. Dalton Trans 47:9057-9063. https://doi.org/10.1039/C8DT01245H

Reddy BJ et al (2019) A facile synthesis of novel $\alpha-\mathrm{ZnMoO}_{4}$ microspheres as electrode material for supercapacitor applications. Bull Mater Sci 42:52. https://doi.org/10.1007/s12034-019-1749-9

Reitz JR et al (2008) Foundations of electromagnetic theory. AddisonWesley Publishing Company, Boston

Ren J et al (2019) $\mathrm{CoS}_{2}$ hollow nanocubes derived from Co-Co Prussian blue analogue: high-performance electrode materials for supercapacitors. J Electroanal Chem 836:30-37. https://doi. org/10.1016/j.jelechem.2019.01.049

Rendón-Angeles JC et al (2016) Synthesis of perovskite oxides by hydrothermal processing - from thermodynamic modelling to practical processing approaches. In: Perovskite materials: synthesis, characterisation, properties, and applications, p 27. https ://doi.org/10.5772/61568

Rezanezhad A et al (2020) Outstanding supercapacitor performance of $\mathrm{Nd}-\mathrm{Mn}$ co-doped perovskite $\mathrm{LaFeO}_{3} @$ nitrogen-doped graphene oxide nanocomposites. Electrochim Acta 335:135699. https:// doi.org/10.1016/j.electacta.2020.135699

Rosa Silva E et al (2019) Carbon-based electrode loaded with Y-doped $\mathrm{SrTiO}_{3}$ perovskite as support for enzyme immobilization in biosensors. Ceram Int. https://doi.org/10.1016/j.ceram int.2019.10.077

Sachdev S (2006) Handbook of magnetism and advanced magnetic materials. https://doi.org/10.1002/9780470022184

Saha $S$ et al (2018) A review on the heterostructure nanomaterials for supercapacitor application. J Energy Storage 17:181-202. https ://doi.org/10.1016/j.est.2018.03.006

Sahoo $S$ et al (2016) Porous ternary high performance supercapacitor electrode based on reduced graphene oxide, $\mathrm{NiMn}_{2} \mathrm{O}_{4}$, and polyaniline. Electrochim Acta 216:386-396. https://doi. org/10.1016/j.electacta.2016.09.030

Saleh Ghadimi L et al (2019) Effect of synthesis route on the electrochemical performance of $\mathrm{CoMnFeO}_{4}$ nanoparticles as a novel supercapacitor electrode material. Appl Surf Sci 494:440-451. https://doi.org/10.1016/j.apsusc.2019.07.183

Salguero Salas MA et al (2019) Synthesis and characterization of alumina-embedded $\mathrm{SrCo}_{0.95} \mathrm{~V}_{0.05} \mathrm{O}_{3}$ nanostructured perovskite: an attractive material for supercapacitor devices. Microporous Mesoporous Mater. https://doi.org/10.1016/j.micro meso.2019.109797

Sami SK et al (2017) Electrodeposited nickel-cobalt sulfide nanosheet on polyacrylonitrile nanofibers: a binder-free electrode for flexible supercapacitors. Mater Res Express 4:116309. https://doi. org/10.1088/2053-1591/aa985b

Samoila P et al (2017) Remarkable catalytic properties of rare-earth doped nickel ferrites synthesized by sol-gel auto-combustion with maleic acid as fuel for CWPO of dyes. Appl Catal B 202:21-32. https://doi.org/10.1016/j.apcatb.2016.09.012

Sankar KV, Selvan RK (2014) The preparation of $\mathrm{MnFe}_{2} \mathrm{O}_{4}$ decorated flexible graphene wrapped with PANI and its electrochemical performances for hybrid supercapacitors. RSC Adv 4:1755517566. https://doi.org/10.1039/C3RA47681B

Sankar KV, Selvan RK (2015) The ternary $\mathrm{MnFe}_{2} \mathrm{O}_{4}$ /graphene/polyaniline hybrid composite as negative electrode for supercapacitors. J Power Sources 275:399-407. https://doi.org/10.1016/j.jpows our.2014.10.183

Saren P et al (2019) Self-assembled GNS wrapped flower-like $\mathrm{MnCo}_{2} \mathrm{O}_{4}$ nanostructures for supercapacitor application. $\mathrm{J}$ Solid State Chem 271:282-291. https://doi.org/10.1016/j. jssc.2018.11.016

Sari FNI, Ting J-M (2018) $\mathrm{MoS}_{2} / \mathrm{MoO}_{x}$-nanostructure-decorated activated carbon cloth for enhanced supercapacitor performance.
Chemsuschem 11:897-906. https://doi.org/10.1002/cssc.20170 2295

Sarkar A et al (2018) Novel hydrothermal synthesis of $\mathrm{CoS}_{2} / \mathrm{MWCNT}$ nanohybrid electrode for supercapacitor: a systematic investigation on the influence of MWCNT. J Phys Chem C 122:1823718246. https://doi.org/10.1021/acs.jpcc.8b04137

Sarmah D, Kumar A (2018) Layer-by-layer self-assembly of ternary $\mathrm{MoS}_{2}-\mathrm{rGO} @$ PPyNTs nanocomposites for high performance supercapacitor electrode. Synth Met 243:75-89. https://doi. org/10.1016/j.synthmet.2018.06.001

Sarno M, Troisi A (2017) Supercapacitors based on high surface area $\mathrm{MoS}_{2}$ and $\mathrm{MoS}_{2}-\mathrm{Fe}_{3} \mathrm{O}_{4}$ nanostructures supported on physical exfoliated graphite. J Nanosci Nanotechnol 17:3735-3743. https ://doi.org/10.1166/jnn.2017.14015

Schaak RE, Mallouk TE (2002) Perovskites by design: a toolbox of solid-state reactions. Chem Mater 14:1455-1471. https://doi. org/10.1021/cm010689m

Selvarajan R et al (2020) Facile synthesis of pervoskite type $\mathrm{BiYO}_{3}$ embedded reduced graphene oxide (RGO) composite for supercapacitor applications. Ceram Int 46:3471-3478. https://doi. org/10.1016/j.ceramint.2019.10.060

Sevilla M et al (2017) Beyond KOH activation for the synthesis of superactivated carbons from hydrochar. Carbon 114:50-58. https ://doi.org/10.1016/j.carbon.2016.12.010

Sha $\mathrm{C}$ et al (2016) 3D ternary nanocomposites of molybdenum disulfide/polyaniline/reduced graphene oxide aerogel for high performance supercapacitors. Carbon 99:26-34. https://doi. org/10.1016/j.carbon.2015.11.066

Shafi PM et al (2018) Enhanced electrochemical performances of agglomeration-free $\mathrm{LaMnO}_{3}$ perovskite nanoparticles and achieving high energy and power densities with symmetric supercapacitor design. Chem Eng J 338:147-156. https://doi. org/10.1016/j.cej.2018.01.022

Shah MS et al (2018) Structural and magnetic properties of praseodymium substituted barium-based spinel ferrites. Mater Res Bull 98:77-82. https://doi.org/10.1016/j.materresbull.2017.09.063

Shanmugavani A, Selvan RK (2014) Synthesis of $\mathrm{ZnFe}_{2} \mathrm{O}_{4}$ nanoparticles and their asymmetric configuration with $\mathrm{Ni}(\mathrm{OH})_{2}$ for a pseudocapacitor. RSC Adv 4:27022-27029. https://doi.org/10.1039/ C4RA01793E

Sharifi I et al (2012) Ferrite-based magnetic nanofluids used in hyperthermia applications. J Magn Magn Mater 324:903-915. https:// doi.org/10.1016/j.jmmm.2011.10.017

Sharifi S et al (2020) Effect of $\mathrm{Co}^{2+}$ content on supercapacitance properties of hydrothermally synthesized $\mathrm{Ni}_{1-\mathrm{x}} \mathrm{Co}_{\mathrm{x}} \mathrm{Fe}_{2} \mathrm{O}_{4}$ nanoparticles. Mater Sci Semicond Process 108:104902. https://doi. org/10.1016/j.mssp.2019.104902

Sharma R et al (2017) Ferrimagnetic $\mathrm{Ni}^{2+}$ doped $\mathrm{Mg}-\mathrm{Zn}$ spinel ferrite nanoparticles for high density information storage. J Alloys Compd 704:7-17. https://doi.org/10.1016/j.jallcom.2017.02.021

Shih Z-Y et al (2013) Synthesis and catalysis of copper sulfide/carbon nanodots for oxygen reduction in direct methanol fuel cells. Appl Catal B 132:363-369. https://doi.org/10.1016/j.apcat b.2012.12.004

Shin J et al (2018) An accurate and stable humidity sensing characteristic of Si FET-type humidity sensor with MoS2 as a sensing layer by pulse measurement. Sens Actuators B Chem 258:574-579. https://doi.org/10.1016/j.snb.2017.11.132

Singh G, Chandra S (2018) Electrochemical performance of $\mathrm{MnFe}_{2} \mathrm{O}_{4}$ nano-ferrites synthesized using thermal decomposition method. Int J Hydrog Energy 43:4058-4066. https://doi.org/10.1016/j. ijhydene.2017.08.181

Siwach PK et al (2008) Low field magnetotransport in manganites. J Phys: Condens Matter 20:273201. https://doi.org/10.1088/0953$8984 / 20 / 27 / 273201$ 
Snook et al (2010) Conducting-polymer-based supercapacitor devices and electrodes. J Power Sources. https://doi.org/10.1016/j.jpows our.2010.06.084

Soares S et al (2018) Nanomedicine: principles, properties, and regulatory issues. Front Chem 6:360. https://doi.org/10.3389/fchem .2018 .00360

Song $\mathrm{K}$ et al (2019) Hierarchical structure of $\mathrm{CoFe}_{2} \mathrm{O}_{4}$ core-shell microsphere coating on carbon fiber cloth for high-performance asymmetric flexible supercapacitor applications. Ionics 25:49054914. https://doi.org/10.1007/s11581-019-03030-4

Song Y-L et al (2020) Molten salt synthesis and supercapacitor properties of oxygen-vacancy $\mathrm{LaMnO}_{3}-\delta$. J Energy Chem 43:173-181. https://doi.org/10.1016/j.jechem.2019.09.007

Sridhar V, Park H (2018) Carbon nanofiber linked $\mathrm{FeS}_{2}$ mesoporous nano-alloys as high capacity anodes for lithium-ion batteries and supercapacitors. J Alloys Compd 732:799-805. https://doi. org/10.1016/j.jallcom.2017.10.252

$\mathrm{Su} \mathrm{L}$ et al (2018) Sprinkling $\mathrm{MnFe}_{2} \mathrm{O}_{4}$ quantum dots on nitrogen-doped graphene sheets: the formation mechanism and application for high-performance supercapacitor electrodes. J Mater Chem A 6:9997-10007. https://doi.org/10.1039/C8TA02982B

Sun Y et al (2011) Graphene based new energy materials. Energy Environ Sci 4:1113-1132. https://doi.org/10.1039/C0EE00683A

Sun $\mathrm{G}$ et al (2015) Hybrid fibers made of molybdenum disulfide, reduced graphene oxide, and multi-walled carbon nanotubes for solid-state, flexible, asymmetric supercapacitors. Angew Chem Int Ed 54:4651-4656. https://doi.org/10.1002/anie.201411533

Sun T et al (2017) Graphene-wrapped CNT@ $\mathrm{MoS}_{2}$ hierarchical structure: synthesis, characterization and electrochemical application in supercapacitors. New J Chem 41:7142-7150. https://doi. org/10.1039/C7NJ00623C

Sun J et al (2018a) Printable nanomaterials for the fabrication of highperformance supercapacitors. Nanomaterials 8:528. https://doi. org/10.3390/nano8070528

Sun Z et al (2018b) From biomass wastes to vertically aligned graphene nanosheet arrays: a catalyst-free synthetic strategy towards highquality graphene for electrochemical energy storage. Chem Eng J 336:550-561. https://doi.org/10.1016/j.cej.2017.12.019

Sun Z et al (2019a) Bifunctional iron disulfide nanoellipsoids for high energy density supercapacitor and electrocatalytic oxygen evolution applications. Inorg Chem Front 6:659-670. https://doi. org/10.1039/c8qi01230j

Sun P et al (2019b) Uniform $\mathrm{MoS}_{2}$ nanolayer with sulfur vacancy on carbon nanotube networks as binder-free electrodes for asymmetrical supercapacitor. Appl Surf Sci 475:793-802. https://doi. org/10.1016/j.apsusc.2019.01.007

Sunarso J et al (2017) Perovskite oxides applications in high temperature oxygen separation, solid oxide fuel cell and membrane reactor: a review. Prog Energy Combust Sci 61:57-77. https://doi. org/10.1016/j.pecs.2017.03.003

Tabrizi AG et al (2017) Facile synthesis of a $\mathrm{MnFe}_{2} \mathrm{O}_{4} / \mathrm{rGO}$ nanocomposite for an ultra-stable symmetric supercapacitor. New J Chem 41:4974-4984. https://doi.org/10.1039/C6NJ04093D

Tang Q et al (2015a) A novel asymmetric supercapacitors based on binder-free carbon fiber paper@nickel cobaltite nanowires and graphene foam electrodes. J Power Sources 273:654-662. https ://doi.org/10.1016/j.jpowsour.2014.09.139

Tang $\mathrm{H}$ et al (2015b) Growth of polypyrrole ultrathin films on $\mathrm{MoS}_{2}$ monolayers as high-performance supercapacitor electrodes. Adv Mater 27:1117-1123. https://doi.org/10.1002/adma.201404622

Tang Y et al (2015c) Synthesis of graphene oxide anchored porous manganese sulfide nanocrystals via the nanoscale Kirkendall effect for supercapacitors. J Mater Chem A. 3:12913-12919. https://doi.org/10.1039/c5ta02480c

Thakur AK et al (2017) Facile synthesis and electrochemical evaluation of PANI/CNT/MoS 2 ternary composite as an electrode material for high performance supercapacitor. Mater Sci Eng B SolidState Mater Adv Technol 223:24-34. https://doi.org/10.1016/j. mseb.2017.05.001

Thiesen B, Jordan A (2008) Clinical applications of magnetic nanoparticles for hyperthermia. Int J Hyperth 24:467-474. https://doi. org/10.1080/02656730802104757

Tian H et al (2019) Nanosheet-assembled $\mathrm{LaMnO}_{3} @ \mathrm{NiCo}_{2} \mathrm{O}_{4}$ nanoarchitecture growth on $\mathrm{Ni}$ foam for high power density supercapacitors. Electrochim Acta 318:651-659. https://doi. org/10.1016/j.electacta.2019.06.133

Tomar AK et al (2018) Fabrication of a Mo-doped strontium cobaltite perovskite hybrid supercapacitor cell with high energy density and excellent cycling life. Chemsuschem 11:4123-4130. https:// doi.org/10.1002/cssc.201801869

Tomar AK et al (2019) Charge storage characteristics of mesoporous strontium titanate perovskite aqueous as well as flexible solidstate supercapacitor cell. J Power Sources 426:223-232. https:// doi.org/10.1016/j.jpowsour.2019.04.049

Tu CC et al (2016) Highly efficient supercapacitor electrode with two-dimensional tungsten disulfide and reduced graphene oxide hybrid nanosheets. J Power Sources 320:78-85. https://doi. org/10.1016/j.jpowsour.2016.04.083

Uke SJ et al (2020) Sol-gel citrate synthesized $\mathrm{Zn}$ doped $\mathrm{MgFe}_{2} \mathrm{O}_{4}$ nanocrystals: a promising supercapacitor electrode material. Mater Sci Energy Technol 3:446-455. https://doi.org/10.1016/j. mset.2020.02.009

Umeshbabu E et al (2015) Synthesis of mesoporous $\mathrm{NiCo}_{2} \mathrm{O}_{4}-\mathrm{rGO}$ by a solvothermal method for charge storage applications. RSC Adv 5:66657-66666. https://doi.org/10.1039/C5RA11239G

Vadiyar MM et al (2015) Mechanochemical growth of a porous $\mathrm{ZnFe}_{2} \mathrm{O}_{4}$ nano-flake thin film as an electrode for supercapacitor application. RSC Adv 5:45935-45942. https://doi.org/10.1039/ C5RA07588B

Vadiyar MM et al (2016a) Reflux condensation mediated deposition of $\mathrm{Co}_{3} \mathrm{O}_{4}$ nanosheets and $\mathrm{ZnFe}_{2} \mathrm{O}_{4}$ nanoflakes electrodes for flexible asymmetric supercapacitor. Electrochim Acta 222:1604-1615. https://doi.org/10.1016/j.electacta.2016.11.146

Vadiyar MM et al (2016b) Low cost flexible 3-D aligned and crosslinked efficient $\mathrm{ZnFe}_{2} \mathrm{O}_{4}$ nano-flakes electrode on stainless steel mesh for asymmetric supercapacitors. J Mater Chem A 4:35043512. https://doi.org/10.1039/C5TA09022A

Veerasubramani GK et al (2014) Synthesis, characterization, and electrochemical properties of $\mathrm{CoMoO}_{4}$ nanostructures. Int J Hydrog Energy 39:5186-5193. https://doi.org/10.1016/j.ijhyd ene.2014.01.069

Veerasubramani GK et al (2016) Improved electrochemical performances of binder-free $\mathrm{CoMoO}_{4}$ nanoplate arrays@ Ni foam electrode using redox additive electrolyte. J Power Sources 306:378-386. https://doi.org/10.1016/j.jpowsour.2015.12.034

Venkatachalam V et al (2017) Double hydroxide mediated synthesis of nanostructured $\mathrm{ZnCo}_{2} \mathrm{O}_{4}$ as high performance electrode material for supercapacitor applications. Chem Eng J 321:474-483. https ://doi.org/10.1016/j.cej.2017.03.148

Vignesh V et al (2018) Electrochemical investigation of manganese ferrites prepared via a facile synthesis route for supercapacitor applications. Colloids Surf A Physicochem Eng Asp 538:668677. https://doi.org/10.1016/j.colsurfa.2017.11.045

Vignesh V et al (2019) Synthesis of GNS-MnS hybrid nanocomposite for enhanced electrochemical energy storage applications. Mater Chem Phys 230:249-257. https://doi.org/10.1016/j.matchemphy s.2019.03.070

Vijayanand S (2010) Synthesis and characterization of spinel type magnetic and non-magnetic oxide nanomaterials. CSIR-National Chemical Laboratory, Pune. https://shodhganga.inflibnet.ac.in/ bitstream/10603/102638/1/01_title.pdf. Accessed 23/07/2020 
Vinuth Raj TN et al (2020) Facile synthesis of perovskite lanthanum aluminate and its green reduced graphene oxide composite for high performance supercapacitors. J Electroanal Chem 858:113830. https://doi.org/10.1016/j.jelechem.2020.113830

$\mathrm{Vu}$ HT et al (2015) Ferroelectric and piezoelectric responses of (110) and (001)-oriented epitaxial $\mathrm{Pb}\left(\mathrm{Zr}_{0.52} \mathrm{Ti}_{0.48}\right) \mathrm{O}_{3}$ thin films on alloxide layers buffered silicon. Mater Res Bull 72:160-167. https ://doi.org/10.1016/j.materresbull.2015.07.043

Wang J et al (2005) Carbon nanotube - conducting-polymer composite nanowires. Langmuir 21:9-12. https://doi.org/10.1021/la047 5977

Wang YG et al (2006) Ordered whiskerlike polyaniline grown on the surface of mesoporous carbon and its electrochemical capacitance performance. Adv Mater 18:2619-2623. https://doi. org/10.1002/adma.200600445

Wang DW et al (2008) 3D aperiodic hierarchical porous graphitic carbon material for high-rate electrochemical capacitive energy storage. Angew Chem Int Ed 47:373-376. https://doi.org/10.1002/ anie. 200702721

Wang Y et al (2009) Supercapacitor devices based on graphene materials. J Phys Chem C 113:13103-13107. https://doi.org/10.1021/ jp902214f

Wang C et al (2011) The electromagnetic property of chemically reduced graphene oxide and its application as microwave absorbing material. Appl Phys Lett 98:072906. https://doi. org/10.1063/1.3555436

Wang $\mathrm{H}$ et al (2012) Review on recent progress in nitrogen-doped graphene: synthesis, characterization, and its potential applications. ACS Catal 2:781-794. https://doi.org/10.1021/cs200652y

Wang D-W et al (2013a) Carbon-sulfur composites for Li-S batteries: status and prospects. J Mater Chem A 1:9382-9394. https://doi. org/10.1039/C3TA11045A

Wang B et al (2013b) Contact-engineered and void-involved silicon/ carbon nanohybrids as lithium-ion-battery anodes. Adv Mater 25:3560-3565. https://doi.org/10.1002/adma.201300844

Wang $\mathrm{K}$ et al (2014a) Conducting polymer nanowire arrays for high performance supercapacitors. Small 10:14-31. https://doi. org/10.1002/smll.201301991

Wang Y et al (2014b) Novel $\mathrm{FeMoO}_{4} /$ graphene composites based electrode materials for supercapacitors. Compos Sci Technol 103:16-21. https://doi.org/10.1016/j.compscitech.2014.08.009

Wang $\mathbf{J}$ et al (2014c) $\mathrm{Ni}_{3} \mathrm{~S}_{2} @ \mathrm{MoS}_{2}$ core/shell nanorod arrays on $\mathrm{Ni}$ foam for high-performance electrochemical energy storage. Nano Energy 7:151-160. https://doi.org/10.1016/j.nanoen.2014.04.019

Wang J-F et al (2015a) Enhanced low-field magnetoresistance in organic/inorganic glycerin $/ \mathrm{Sr}_{2} \mathrm{FeMoO}_{6}$ composites. J Alloys Compd 621:131-135. https://doi.org/10.1016/j.jallc om.2014.09.164

Wang L et al (2015b) One-pot synthesis of 3D flower-like heterostructured $\mathrm{SnS}_{2} / \mathrm{MoS}_{2}$ for enhanced supercapacitor behavior. RSC Adv 5:89069-89075. https://doi.org/10.1039/C5RA16300E

Wang L et al (2016a) Microstructure and mechanical properties of $\mathrm{Ba}_{0.5} \mathrm{Sr}_{0.5} \mathrm{Co}_{0.8} \mathrm{Fe}_{0.2} \mathrm{O}_{3-\delta}$ perovskite-structured oxides doped with different contents of Ni. Mater Sci Eng, A 658:280-288. https:// doi.org/10.1016/j.msea.2016.02.008

Wang XW et al (2016b) Structural and electrochemical properties of $\mathrm{La}_{0.85} \mathrm{Sr}_{0.15} \mathrm{MnO}_{3}$ powder as an electrode material for supercapacitor. J Alloys Compd 675:195-200. https://doi.org/10.1016/j. jallcom.2016.03.048

Wang $\mathrm{M}$ et al (2016c) Hierarchically layered $\mathrm{MoS}_{2} / \mathrm{Mn}_{3} \mathrm{O}_{4}$ hybrid architectures for electrochemical supercapacitors with enhanced performance. Electrochim Acta 209:389-398. https://doi. org/10.1016/j.electacta.2016.05.078

Wang $\mathrm{Z}$ et al (2017a) Ni foam-supported carbon-sheathed $\mathrm{NiMoO}_{4}$ nanowires as integrated electrode for high-performance hybrid supercapacitors. ACS Sustain Chem Eng 5:5964-5971. https:// doi.org/10.1021/acssuschemeng.7b00758

Wang J et al (2017b) High-performance supercapacitor electrode based on a nanocomposite of polyaniline and chemically exfoliated $\mathrm{MoS}_{2}$ nanosheets. J Solid State Electrochem 21:2071-2077. https ://doi.org/10.1007/s 10008-017-3536-0

Wang $\mathrm{H}$ et al (2017c) Design and fabrication of macroporous polyaniline nanorods@graphene-like $\mathrm{MoS}_{2}$ nanocomposite with high electrochemical performance for supercapacitors. J Alloys Compd 699:176-182. https://doi.org/10.1016/j.jallc om.2016.12.344

Wang K et al (2017d) General solution-processed formation of porous transition-metal oxides on exfoliated molybdenum disulfides for high-performance asymmetric supercapacitors. J Mater Chem A 5:11236-11245. https://doi.org/10.1039/c7ta01457k

Wang L et al (2017e) Supercapacitor performances of the $\mathrm{MoS}_{2} /$ $\mathrm{CoS} 2$ nanotube arrays in situ grown on Ti plate. J Phys Chem C 121:9089-9095. https://doi.org/10.1021/acs.jpcc.6b13026

Wang L et al (2017f) Titanium plate supported $\mathrm{MoS}_{2}$ nanosheet arrays for supercapacitor application. Appl Surf Sci 396:1466-1471. https://doi.org/10.1016/j.apsusc.2016.11.193

Wang S et al (2017g) Three-dimensional MoS $@$ CNT/RGO network composites for high-performance flexible supercapacitors. Chem Eur J 23:3438-3446. https://doi.org/10.1002/chem.201605465

Wang J et al (2018a) Confined self-assembly in two-dimensional interlayer space: monolayered mesoporous carbon nanosheets with in-plane orderly arranged mesopores and a highly graphitized framework. Angew Chem Int Ed 57:2894-2898. https://doi. org/10.1002/anie.201712959

Wang X et al (2018b) High-performance stretchable supercapacitors based on intrinsically stretchable acrylate rubber/MWCNTs@ conductive polymer composite electrodes. J Mater Chem A 6:4432-4442. https://doi.org/10.1039/C7TA11173H

Wang Z et al (2019a) Non-volatile resistance switching properties of $\mathrm{PbTiO}_{3}$ based metal-ferroelectric-semiconductor structures. Thin Solid Films 671:59-63. https://doi.org/10.1016/j.tsf.2018.12.031

Wang W et al (2019b) Synthesis, morphology and electrochemical performances of perovskite-type oxide $\mathrm{La}_{\mathrm{x}} \mathrm{Sr}_{1-\mathrm{x}} \mathrm{FeO}_{3}$ nanofibers prepared by electrospinning. J Phys Chem Solids 124:144-150. https://doi.org/10.1016/j.jpcs.2018.09.011

Wang Y et al (2019c) Conductive polymers for stretchable supercapacitors. Nano Res 12:1978-1987. https://doi.org/10.1007/s1227 4-019-2296-9

Wang $\mathrm{W}$ et al (2020a) High-performance $\mathrm{Gd}_{\mathrm{x}} \mathrm{Sr}_{1-\mathrm{x}} \mathrm{NiO}_{3}$ porous nanofibers prepared by electrospinning for symmetric and asymmetric supercapacitors. J Phys Chem Solids 140:109361. https:// doi.org/10.1016/j.jpcs.2020.109361

Wang J-A et al (2020b) Constructing a high-performance quasi-solidstate asymmetric supercapacitor: $\mathrm{NaxMnO}_{2} @ \mathrm{CNT} / W P U-P A A K-$ $\mathrm{Na}_{2} \mathrm{SO}_{4} / \mathrm{AC}-\mathrm{CNT}$. Electrochim Acta 334:135576. https://doi. org/10.1016/j.electacta.2019.135576

Wang M et al (2020c) Development of polyoxometalate-anchored 3D hybrid hydrogel for high-performance flexible pseudo-solidstate supercapacitor. Electrochim Acta 329:135181. https://doi. org/10.1016/j.electacta.2019.135181

Wang J et al (2020d) Na-ion conducting gel polymer membrane for flexible supercapacitor application. Electrochim Acta 330:135322. https://doi.org/10.1016/j.electacta.2019.135322

Wei T-Y et al (2010) A cost-effective supercapacitor material of ultrahigh specific capacitances: spinel nickel cobaltite aerogels from an epoxide-driven sol-gel process. Adv Mater 22:347-351. https ://doi.org/10.1002/adma.200902175

Wei $\mathrm{M}$ et al (2019) Ruddlesden-Popper type $\mathrm{La}_{2} \mathrm{NiO}_{4+\delta}$ oxide coated by $\mathrm{Ag}$ nanoparticles as an outstanding anion intercalation cathode for hybrid supercapacitors. Appl Surf Sci 484:551-559. https ://doi.org/10.1016/j.apsusc.2019.04.015 
Wen S et al (2018) Hierarchical $\mathrm{MoS}_{2}$ nanowires/ $\mathrm{NiCo}_{2} \mathrm{O}_{4}$ nanosheets supported on $\mathrm{Ni}$ foam for high-performance asymmetric supercapacitors. Appl Surf Sci 428:616-622. https://doi.org/10.1016/j. apsusc.2017.09.189

Weng Q et al (2015) Supercapacitive energy storage performance of molybdenum disulfide nanosheets wrapped with microporous carbons. J Mater Chem A 3:3097-3102. https://doi.org/10.1039/ C4TA06303A

Winder S (2016) Power supplies for LED driving. Newnes, Oxford

Wongpratat U et al (2020) Effects of nickel and magnesium on electrochemical performances of partial substitution in spinel ferrite. J Alloys Compd 831:154718. https://doi.org/10.1016/j.jallc om.2020.154718

Wu C et al (2015a) Direct growth of urchin-like $\mathrm{ZnCo}_{2} \mathrm{O}_{4}$ microspheres assembled from nanowires on nickel foam as high-performance electrodes for supercapacitors. Electrochim Acta 169:202-209. https://doi.org/10.1016/j.electacta.2015.04.079

$\mathrm{Wu} \mathrm{ZY}$ et al (2015b) Iron carbide nanoparticles encapsulated in mesoporous $\mathrm{Fe}-\mathrm{N}$-doped carbon nanofibers for efficient electrocatalysis. Angew Chem Int Ed 54:8179-8183. https://doi. org/10.1002/ange.201502173

$\mathrm{Wu} \mathrm{Z}$ et al (2017) Silver wrapped $\mathrm{MoS}_{2}$ hybrid electrode materials for high-performance supercapacitor. J Alloys Compd 708:763-768. https://doi.org/10.1016/j.jallcom.2017.03.048

Xia X et al (2013) One-step synthesis of $\mathrm{CoMoO}_{4}$ /graphene composites with enhanced electrochemical properties for supercapacitors. Electrochim Acta 99:253-261. https://doi.org/10.1016/j.elect acta.2013.03.131

Xia D et al (2018) Molybdenum and tungsten disulfides-based nanocomposite films for energy storage and conversion: a review, vol 348. Elsevier, Amsterdam, pp 908-928. https://doi.org/10.1016/j. cej.2018.04.207

Xiao Y et al (2013) $\mathrm{MnFe}_{2} \mathrm{O}_{4}$-graphene nanocomposites with enhanced performances as anode materials for $\mathrm{Li}$-ion batteries. Phys Chem Chem Phys 15:3939-3945. https://doi.org/10.1039/C3CP50220A

Xie X et al (2019) Enhanced piezoelectric properties and temperature stability of $\mathrm{Bi}_{4} \mathrm{Ti}_{3} \mathrm{O}_{12}$-based aurivillius ceramics via W/Nb substitution. J Eur Ceram Soc 39:957-962. https://doi.org/10.1016/j. jeurceramsoc.2018.12.061

Xing JC et al (2014a) Hierarchical mesoporous $\operatorname{CoS}_{2}$ microspheres: morphology-controlled synthesis and their superior pseudocapacitive properties. Electrochim Acta 149:285-292. https://doi. org/10.1016/j.electacta.2014.10.069

Xing JC et al (2014b) Fabrication and shape evolution of $\mathrm{CoS}_{2}$ octahedrons for application in supercapacitors. Electrochim Acta 136:550-556. https://doi.org/10.1016/j.electacta.2014.05.118

$\mathrm{Xu} \mathrm{C}$ et al (2013) Graphene-based electrodes for electrochemical energy storage. Energy Environ Sci 6:1388-1414. https://doi. org/10.1039/C3EE23870A

Xu K et al (2014) Hierarchical mesoporous $\mathrm{NiCo}_{2} \mathrm{O}_{4} @ \mathrm{MnO}_{2}$ coreshell nanowire arrays on nickel foam for aqueous asymmetric supercapacitors. J Mater Chem A 2:4795-4802. https://doi. org/10.1039/C3TA14647B

$\mathrm{Xu} \mathrm{R}$ et al (2017) A two-step hydrothermal synthesis approach to synthesize $\mathrm{NiCo}_{2} \mathrm{~S}_{4} / \mathrm{NiS}$ hollow nanospheres for high-performance asymmetric supercapacitors. Appl Surf Sci 422:597-606. https ://doi.org/10.1016/j.apsusc.2017.06.003

$\mathrm{Xu} \mathrm{K}$ et al (2018a) Synthesis of hollow $\mathrm{NiCo}_{2} \mathrm{O}_{4}$ nanospheres with large specific surface area for asymmetric supercapacitors. J Colloid Interface Sci 511:456-462. https://doi.org/10.1016/j. jcis.2017.09.113

$\mathrm{Xu} \mathrm{J}$ et al (2018b) Facile synthesis of NiS anchored carbon nanofibers for high-performance supercapacitors. Appl Surf Sci 434:112119. https://doi.org/10.1016/j.apsusc.2017.09.233
$\mathrm{Xu}$ X et al (2019a) Double perovskites in catalysis, electrocatalysis, and photo(electro)catalysis. Trends Chem 1:410-424. https://doi. org/10.1016/j.trechm.2019.05.006

$\mathrm{Xu} \mathrm{J}$ et al (2019b) g- $\mathrm{C}_{3} \mathrm{~N}_{4}$ anchored with $\mathrm{MoS}_{2}$ ultrathin nanosheets as high performance anode material for supercapacitor. Mater Lett 241:35-38. https://doi.org/10.1016/j.matlet.2019.01.041

$\mathrm{Xu}$ X et al (2019c) Flexible symmetric supercapacitor with ultrahigh energy density based on NiS/MoS $\mathrm{S}_{2} @ \mathrm{~N}-\mathrm{rGO}$ hybrids electrode. J Colloid Interface Sci 543:147-155. https://doi.org/10.1016/j. jcis.2019.02.054

$\mathrm{Xu} \mathrm{Y}$ et al (2019d) 3D hybrids based on $\mathrm{WS}_{2} / \mathrm{N}, \mathrm{S}$ co-doped reduced graphene oxide: facile fabrication and superior performance in supercapacitors. Appl Surf Sci 480:1126-1135. https://doi. org/10.1016/j.apsusc.2019.02.217

$\mathrm{Xu} \mathrm{Z}$ et al (2020) Investigation on the role of different conductive polymers in supercapacitors based on a zinc sulfide/reduced graphene oxide/conductive polymer ternary composite electrode. RSC Adv 10:3122-3129. https://doi.org/10.1039/C9RA07842H

Yadav S, Devi A (2020) Recent advancements of metal oxides/nitrogen-doped graphene nanocomposites for supercapacitor electrode materials. J Energy Storage 30:101486. https://doi.org/10.1016/j. est.2020.101486

Yadav R, Dixit CK (2017) Synthesis, characterization and prospective applications of nitrogen-doped graphene: a short review. J Sci Adv Mater Dev 2:141-149. https://doi.org/10.1016/j.jsamd 2017.05.007

Yadav RS et al (2018) Structural, magnetic, elastic, dielectric and electrical properties of hot-press sintered $\mathrm{Co} 1-\mathrm{xZnxFe} 2 \mathrm{O} 4(\mathrm{x}=0.0$, 0.5) spinel ferrite nanoparticles. J Magn Magn Mater 447:48-57. https://doi.org/10.1016/j.jmmm.2017.09.033

Yakout SM et al (2019) Role of non-magnetic dopants on the room temperature ferromagnetism and optical properties of $\mathrm{BaSnO}_{3}$ perovskite. J Solid State Chem. https://doi.org/10.1016/j. jssc. 2019.121028

Yan Z, Luo J (2017) Effects of CeZn co-substitution on structure, magnetic and microwave absorption properties of nickel ferrite nanoparticles. J Alloys Compd 695:1185-1195. https://doi. org/10.1016/j.jallcom.2016.08.333

Yang J, Guo Y (2018) Nanostructured perovskite oxides as promising substitutes of noble metals catalysts for catalytic combustion of methane. Chin Chem Lett 29:252-260. https://doi.org/10.1016/j. cclet.2017.09.013

Yang SJ et al (2013) Preparation and exceptional lithium anodic performance of porous carbon-coated $\mathrm{ZnO}$ quantum dots derived from a metal-organic framework. J Am Chem Soc 135:7394-7397. https://doi.org/10.1021/ja311550t

Yang MH et al (2015) High-performance supercapacitor based on three-dimensional $\mathrm{MoS}_{2}$ /graphene aerogel composites. Compos Sci Technol 121:123-128. https://doi.org/10.1016/j.compscitec h.2015.11.004

Yang C et al (2016) Rational synthesis of carbon shell coated polyaniline/ $\mathrm{MoS}_{2}$ monolayer composites for high-performance supercapacitors. Nano Res 9:951-962. https://doi.org/10.1007/s1227 4-016-0983-3

Yang X et al (2017) Arrays of hierarchical nickel sulfides/MoS nanosheets supported on carbon nanotubes backbone as advanced anode materials for asymmetric supercapacitor. J Power Sources 343:373-382. https://doi.org/10.1016/j.jpowsour.2017.01.078

Yang $\mathrm{S}$ et al (2018) Preparation of defective $\mathrm{ZnFe}_{2} \mathrm{O}_{4}$ /graphene composites and their charge storage properties. Electrochem Commun 92:19-23. https://doi.org/10.1016/j.elecom.2018.05.017

Yang $\mathrm{Z}$ et al (2019a) Carbon nanotube- and graphene-based nanomaterials and applications in high-voltage supercapacitor: a review. Carbon 141:467-480. https://doi.org/10.1016/j.carbo n.2018.10.010 
Yang C-C et al (2019b) Templating synthesis of nickel cobaltite nanoflakes and their nanocomposites for making high-performance symmetric supercapacitors. Mater Today Energy 14:100356. https://doi.org/10.1016/j.mtener.2019.100356

Yang Z et al (2019c) Free-standing PEDOT/polyaniline conductive polymer hydrogel for flexible solid-state supercapacitors. Electrochim Acta 322:134769. https://doi.org/10.1016/j.elect acta.2019.134769

Yao L et al (2017) Facial synthesis of carbon-coated $\mathrm{ZnFe}_{2} \mathrm{O}_{4}$ /graphene and their enhanced lithium storage properties. J Nanopart Res 19:261. https://doi.org/10.1007/s11051-017-3935-2

Yi T-F et al (2020) Porous spherical NiO@ $\mathrm{NiMoO}_{4} @$ PPy nanoarchitectures as advanced electrochemical pseudocapacitor materials. Sci Bull 65:546-556. https://doi.org/10.1016/j.scib.2020.01.011

Yin J et al (2006) Nanocrystalline Co-ferrite films with high perpendicular coercivity. Appl Phys Lett 88:162502. https://doi. org/10.1063/1.2196472

Yin Y et al (2013) Nano $\mathrm{MgFe}_{2} \mathrm{O}_{4}$ synthesized by sol-gel auto-combustion method as anode materials for lithium ion batteries. $\mathrm{J}$ Sol-Gel Sci Technol 66:540-543. https://doi.org/10.1007/s1097 $1-013-2967-z$

Yin J et al (2014) Meso-and micro-porous composite carbons derived from humic acid for supercapacitors. Electrochim Acta 136:504512. https://doi.org/10.1016/j.electacta.2014.05.115

Yin $\mathrm{Z}$ et al (2015a) Hierarchical nanosheet-based $\mathrm{NiMoO}_{4}$ nanotubes: synthesis and high supercapacitor performance. J Mater Chem A 3:739-745. https://doi.org/10.1039/C4TA05468G

Yin $\mathrm{Z}$ et al (2015b) Hierarchical nanosheet-based $\mathrm{CoMoO}_{4}-\mathrm{NiMoO}_{4}$ nanotubes for applications in asymmetric supercapacitors and the oxygen evolution reaction. J Mater Chem A 3:22750-22758. https://doi.org/10.1039/C5TA05678K

Yu XY, David Lou XW (2018) Mixed metal sulfides for electrochemical energy storage and conversion. Adv Energy Mater 8:1701592. https://doi.org/10.1002/aenm.201701592

Yu EH et al (2012) Direct oxidation alkaline fuel cells: from materials to systems. Energy Environ Sci 5:5668-5680. https://doi. org/10.1039/C2EE02552C

Yu X-Y et al (2016) Metal sulfide hollow nanostructures for electrochemical energy storage. Adv Energy Mater 6:1501333. https:// doi.org/10.1002/aenm.201501333

Yu S et al (2018) Synthesis and application of iron-based nanomaterials as anodes of lithium-ion batteries and supercapacitors, vol 6 . Royal Society of Chemistry, London, pp 9332-9367. https://doi. org/10.1039/c8ta01683f

Yuan YF et al (2017) Freestanding hierarchical $\mathrm{NiO} / \mathrm{MnO}_{2}$ core/shell nanocomposite arrays for high-performance electrochemical energy storage. Electrochim Acta 227:303-309. https://doi. org/10.1016/j.electacta.2017.01.002

Yuan D et al (2020) Atomically thin mesoporous $\mathrm{NiCo}_{2} \mathrm{O}_{4}$ grown on holey graphene for enhanced pseudocapacitive energy storage. J Mater Chem 8:13443-13451. https://doi.org/10.1039/D0TA0 3007D

Yuvaraj S et al (2016) An overview of AB2O4-and A2BO4-structured negative electrodes for advanced Li-ion batteries. Rsc Adv 6:21448-21474. https://doi.org/10.1039/C5RA23503K

Žalnèravičius R et al (2018) Fe(II)-substituted cobalt ferrite nanoparticles against multidrug resistant microorganisms. Appl Surf Sci 435:141-148. https://doi.org/10.1016/j.apsusc.2017.11.028

Zeng X et al (2017) Three-dimensional hollow $\mathrm{CoS}_{2}$ nanoframes fabricated by anion replacement and their enhanced pseudocapacitive performances. Electrochim Acta 240:341-349. https://doi. org/10.1016/j.electacta.2017.04.060

Zha D et al (2015) Strongly coupled manganese ferrite/carbon black/ polyaniline hybrid for low-cost supercapacitors with high rate capability. Electrochim Acta 185:218-228. https://doi. org/10.1016/j.electacta.2015.10.139
Zha D et al (2017) Intimately coupled hybrid of carbon black/nickel cobaltite for supercapacitors with enhanced energy-storage properties and ultra-long cycle life. Electrochim Acta 257:494-503. https://doi.org/10.1016/j.electacta.2017.10.104

Zhai T et al (2017) Phosphate ion functionalized $\mathrm{Co}_{3} \mathrm{O}_{4}$ ultrathin nanosheets with greatly improved surface reactivity for high performance pseudocapacitors. Adv Mater 29:1604167. https:// doi.org/10.1002/adma.201604167

Zhang W-J (2011) Lithium insertion/extraction mechanism in alloy anodes for lithium-ion batteries. J Power Sources 196:877-885. https://doi.org/10.1016/j.jpowsour.2010.08.114

Zhang H, Yi J (2018) Enhanced ethanol gas sensing performance of $\mathrm{ZnO}$ nanoflowers decorated with $\mathrm{LaMnO}_{3}$ perovskite nanoparticles. Mater Lett 216:196-198. https://doi.org/10.1016/j.matle t.2018.01.018

Zhang J, Zhao XS (2012) Conducting polymers directly coated on reduced graphene oxide sheets as high-performance supercapacitor electrodes. J Phys Chem C 116:5420-5426. https://doi. org/10.1021/jp211474e

Zhang LL et al (2010) Layered graphene oxide nanostructures with sandwiched conducting polymers as supercapacitor electrodes. Langmuir 26:17624-17628. https://doi.org/10.1021/la103413s

Zhang $C$ et al (2012) Iron phthalocyanine and nitrogen-doped graphene composite as a novel non-precious catalyst for the oxygen reduction reaction. Nanoscale 4:7326-7329. https://doi.org/10.1039/ C2NR32612D

Zhang T et al (2013a) Photocatalytic water splitting for hydrogen generation on cubic, orthorhombic, and tetragonal $\mathrm{KNbO}_{3}$ microcubes. Nanoscale 5:8375-8383. https://doi.org/10.1039/C3NR0 $2356 \mathrm{G}$

Zhang L et al (2013b) Hierarchical tubular structures constructed by carbon-coated $\mathrm{SnO}_{2}$ nanoplates for highly reversible lithium storage. Adv Mater 25:2589-2593. https://doi.org/10.1002/ adma.201300105

Zhang Z et al (2014) One-pot synthesis of hierarchically nanostructured $\mathrm{Ni}_{3} \mathrm{~S}_{2}$ dendrites as active materials for supercapacitors. Electrochim Acta 149:316-323. https://doi.org/10.1016/j.elect acta.2014.10.097

Zhang J et al (2015a) Binary nickel-cobalt oxides electrode materials for high-performance supercapacitors: influence of its composition and porous nature. ACS Appl Mater Interfaces 7:1763017640. https://doi.org/10.1021/acsami.5b04463

Zhang $\mathrm{Z}$ et al (2015b) Facile hydrothermal synthesis of $\mathrm{NiMoO}_{4} @$ $\mathrm{CoMoO}_{4}$ hierarchical nanospheres for supercapacitor applications. Phys Chem Chem Phys 17:20795-20804. https://doi. org/10.1039/C5CP03331D

Zhang Y et al (2016a) Full synergistic contribution of electrodeposited three-dimensional $\mathrm{NiCo}_{2} \mathrm{O}_{4} @ \mathrm{MnO}_{2}$ nanosheet networks electrode for asymmetric supercapacitors. Nano Energy. 27:627-637. https://doi.org/10.1016/j.nanoen.2016.08.013

Zhang $\mathrm{C}$ et al (2016b) Multiferroicity in $\mathrm{SmFeO}_{3}$ synthesized by hydrothermal method. J Alloys Compd 665:152-157. https:// doi.org/10.1016/j.jallcom.2016.01.042

Zhang $\mathrm{G}$ et al (2016c) Inorganic perovskite photocatalysts for solar energy utilization. Chem Soc Rev 45:5951-5984. https://doi. org/10.1039/C5CS00769K

Zhang D et al (2016d) Synthesis of novel $\mathrm{CoS}_{2}$ nanodendrites with high performance supercapacitors. Int J Electrochem Sci 11:67916798. https://doi.org/10.20964/2016.08.44

Zhang T et al (2016e) Design and preparation of $\mathrm{MoO}_{2} / \mathrm{MoS}_{2}$ as negative electrode materials for supercapacitors. Mater Des 112:8896. https://doi.org/10.1016/j.matdes.2016.09.054

Zhang J et al (2016f) Facile fabrication of supercapacitors with high rate capability using graphene/nickel foam electrode. Electrochim Acta 209:85-94. https://doi.org/10.1016/j.electacta.2016.05.071 
Zhang S et al (2017a) Synthesis of rambutan-like $\mathrm{MoS}_{2} /$ mesoporous carbon spheres nanocomposites with excellent performance for supercapacitors. Appl Surf Sci 396:994-999. https://doi. org/10.1016/j.apsusc.2016.11.074

Zhang G et al (2017b) One-pot synthesis of $\gamma$-MnS/reduced graphene oxide with enhanced performance for aqueous asymmetric supercapacitors. Nanotechnology 28:065402. https://doi. org/10.1088/1361-6528/AA52A5

Zhang $\mathbf{J}$ et al (2017c) Facile aqueous route to nitrogen-doped mesoporous carbons. J Am Chem Soc 139:12931-12934. https ://doi.org/10.1021/jacs.7b08133

Zhang D et al (2018a) A facile strategy for $\mathrm{ZnFe}_{2} \mathrm{O}_{4}$ coating preparing by electrophoretic deposition and its supercapacitor performances. J Mater Sci: Mater Electron 29:5454-5458. https://doi. org/10.1007/s10854-017-8512-z

Zhang X et al (2018b) Ultrathin mesoporous $\mathrm{NiMoO}_{4}$-modified $\mathrm{MoO}_{3}$ core/shell nanostructures: enhanced capacitive storage and cycling performance for supercapacitors. Chem Eng J 353:615625. https://doi.org/10.1016/j.cej.2018.07.160

Zhang R et al (2018c) Novel ternary nanocomposites of MWCNTs/ $\mathrm{PANI} / \mathrm{MoS}_{2}$ : preparation, characterization and enhanced electrochemical capacitance. R Soc Open Sci 5:171365. https://doi. org/10.1098/rsos.171365

Zhang $\mathrm{H}$ et al (2019a) Tuning the electrochemical performance of $\mathrm{NiCo}_{2} \mathrm{O}_{4} @ \mathrm{NiMoO}_{4}$ core-shell heterostructure by controlling the thickness of the $\mathrm{NiMoO}_{4}$ shell. Chem Eng J 370:400-408. https://doi.org/10.1016/j.cej.2019.03.168

Zhang J et al (2019b) Electrochemical capacitive properties of allsolid-state supercapacitors based on ternary $\mathrm{MoS}_{2} / \mathrm{CNTs}-\mathrm{MnO}_{2}$ hybrids and ionic mixture electrolyte. J Alloys Compd 780:276283. https://doi.org/10.1016/j.jallcom.2018.11.332

Zhang X et al (2020a) Mesoporous $\mathrm{NiMoO}_{4}$ microspheres decorated by Ag quantum dots as cathode material for asymmetric supercapacitors: enhanced interfacial conductivity and capacitive storage. Appl Surf Sci 505:144513. https://doi.org/10.1016/j.apsus c. 2019.144513

Zhang Q et al (2020b) Intercalation and exfoliation chemistries of transition metal dichalcogenides. J Mater Chem A. https://doi. org/10.1039/D0TA03727C

Zhang C et al (2020c) Planar supercapacitor with high areal capacitance based on $\mathrm{Ti}_{3} \mathrm{C}_{2} /$ polypyrrole composite film. Electrochim Acta 330:135277. https://doi.org/10.1016/j.electacta.2019.13527 7

Zhang W et al (2020d) Supramolecule-assisted synthesis of cyclodextrin polymer functionalized polyaniline/carbon nanotube with core-shell nanostructure as high-performance supercapacitor material. Electrochim Acta 331:135345. https://doi. org/10.1016/j.electacta.2019.135345

Zhao W et al (2017a) Lychee-like $\mathrm{FeS}_{2} @ \mathrm{FeSe}_{2}$ core-shell microspheres anode in sodium ion batteries for large capacity and ultralong cycle life. J Mater Chem A 5:19195-19202. https:// doi.org/10.1039/C7TA05931K
Zhao C et al (2017b) Alternately stacked metallic 1T-MoS 2 /polyaniline heterostructure for high-performance supercapacitors. Chem Eng J 330:462-469. https://doi.org/10.1016/j.cej.2017.07.129

Zhao Y et al (2017c) Facile preparation of $\mathrm{NiFe}_{2} \mathrm{O}_{4} / \mathrm{MoS}_{2}$ composite material with synergistic effect for high performance supercapacitor. J Alloys Compd 726:608-617. https://doi.org/10.1016/j. jallcom.2017.07.327

Zhao C et al (2017d) One-pot hydrothermal synthesis of RGO/FeS composite on Fe foil for high performance supercapacitors. Electrochim Acta 246:497-506. https://doi.org/10.1016/j.elect acta.2017.06.090

Zhao C et al (2018) Facile construction of $\mathrm{MoS}_{2} / \mathrm{RCF}$ electrode for high-performance supercapacitor. Carbon 127:699-706. https:// doi.org/10.1016/j.carbon.2017.11.052

Zhao C et al (2020) Stretchability enhancement of buckled polypyrrole electrodes for stretchable supercapacitors via engineering substrate surface roughness. Electrochim Acta 343:136099. https ://doi.org/10.1016/j.electacta.2020.136099

Zhou G et al (2014) Simple method for the preparation of highly porous $\mathrm{ZnCo}_{2} \mathrm{O}_{4}$ nanotubes with enhanced electrochemical property for supercapacitor. Electrochim Acta 123:450-455. https://doi. org/10.1016/j.electacta.2014.01.018

Zhou M et al (2015) One-pot construction of three dimensional $\mathrm{CoMoO}_{4} / \mathrm{Co}_{3} \mathrm{O}_{4}$ hybrid nanostructures and their application in supercapacitors. J Mater Chem A 3:21201-21210. https://doi. org/10.1039/C5TA05658F

Zhou R et al (2017) Hierarchical $\mathrm{MoS}_{2}$-coated three-dimensional graphene network for enhanced supercapacitor performances. J Power Sources 352:99-110. https://doi.org/10.1016/j.jpows our.2017.03.134

Zhou S et al (2019) Microstructure and dielectric properties of high entropy $\mathrm{Ba}\left(\mathrm{Zr}_{0.2} \mathrm{Ti}_{0.2} \mathrm{Sn}_{0.2} \mathrm{Hf}_{0.2} \mathrm{Me}_{0.2}\right) \mathrm{O}_{3}$ perovskite oxides. Ceram Int. https://doi.org/10.1016/j.ceramint.2019.11.239

Zhou C et al (2020) Preparation of quinone modified graphene-based fiber electrodes and its application in flexible asymmetrical supercapacitor. Electrochim Acta 336:135628. https://doi. org/10.1016/j.electacta.2020.135628

Zhu Y et al (2012) New routes to graphene, graphene oxide and their related applications. Adv Mater 24:4924-4955. https://doi. org/10.1002/adma.201202321

$\mathrm{Zhu} \mathrm{M}$ et al (2015) Facile solvothermal synthesis of porous $\mathrm{ZnFe}_{2} \mathrm{O}_{4}$ microspheres for capacitive pseudocapacitors. RSC Adv 5:39270-39277. https://doi.org/10.1039/C5RA00447K

Zhu L et al (2016) Perovskite $\mathrm{SrCo}_{0.9} \mathrm{Nb}_{0.1} \mathrm{O}_{3-\delta}$ as an anion-intercalated electrode material for supercapacitors with ultrahigh volumetric energy density. Angew Chem Int Ed 55:9576-9579. https://doi. org/10.1002/ange.201603601

Publisher's Note Springer Nature remains neutral with regard to jurisdictional claims in published maps and institutional affiliations. 